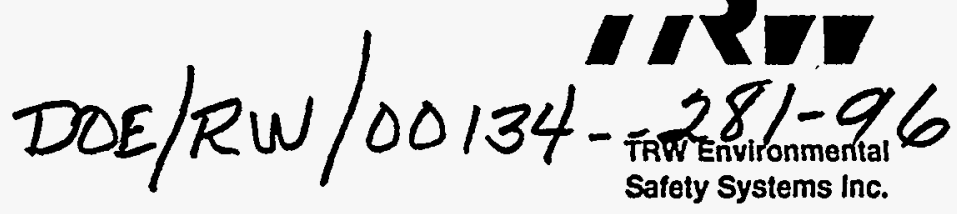

\section{The Vegetation of Yucca Mountain: Description and Ecology}

\section{RECEIVED}

SEP 111996.

\section{OSTI}

\section{Civilian Radioactive Waste Management System \\ Management \& Operating Contractor}

B\&W Federal Services Duke Engineering \& Services, Inc. E.R. Johnson Assoclates, Inc. Fluor Daniel, Inc. Framatome Cogema Fuels Integrated Resources Group INTERA, Inc.

Prepared by: TRW Environmental Safety Systems Inc.
JK Research Associates, Inc. Klewit/Parsons Brinckerhoft Lawrence Berkeley Laboratory Lawrence Livermore National Laboratory Logicon RDA Los Alamos National Laboratory Morrison-Knudsen Corporation

Prepared for:

U.S. Department of Energy Office of Civilian Radioactive Waste Management 1000 Independence Avenue, S.W. Washington, D.C. 20565
SAIC

Sandia National Laboratories TRW Environmental Safety Systems inc. Woodward-Clyde Federal Services Winston \& Strawn Cooperating Federal Agency: U.S. Geological Survey

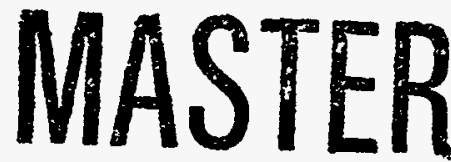
DISTRIBITION OF THIS DOCUMENT IS UNLIMITED PJ 


\section{DISCLAIMER}

This report was prepared as an account of work sponsored by an agency of the United States Government. Neither the United States Government nor any agency thereof, nor any of their employees, makes any warranty, express or implied, or assumes any legal liability or responsibility for the accuracy, completeness, or usefulness of any information, apparatus, product, or process disclosed, or represents that its use would not infringe privately owned rights. Reference herein to any specific commercial product, process, or service by trade name, trademark, manufacturer, or otherwise does not necessarily constitute or imply its endorsement, recommendation, or favoring by the United States Government or any agency thereof. The views and opinions of authors expressed herein do not necessarily state or reflect those of the United States Government or any agency thereof. 


\section{DISCLAIMER}

Portions of this document may be illegible in electronic image products. Images are produced from the best available original document. 


$$
\text { DoefRW/00/34--28/-96 }
$$

\section{Civilian Radioactive Waste Management System Management and Operating Contractor}

The Vegetation of Yucca Mountain: Description and Ecology

(SCPB: N/A)

B0000000-01717-5705-00030 REV 00

March 29, 1996

Prepared for:

U.S. Department of Energy

Yucca Mountain Site Characterization Project

P.O. Box 98608

Las Vegas, Nevada 89193-8608

Prepared by:

TRW Environmental Safety Systems Inc.

101 Convention Center Drive

Las Vegas, Nevada 8910

Under Contract Number

DE-AC01-91RW00134 


\begin{abstract}
Vegetation at Yucca Mountain, Nevada, was monitored over a 6-year period, from 1989 through 1994. Yucca Mountain is located at the northern limit of the Mojave Desert and is the only location being studied as a potential repository for high-level nuclear waste. These studies establish a baseline for determining the ecological impact of site characterization activities, they provide input for site characterization research and modeling, and they clarify vegetation community dynamics and relationships to the physical environment. Cover, density, production, and species composition of vascular plants were monitored at 48 Ecological Study Plots stratified in four vegetation associations. Precipitation, soil moisture, and maximum and minimum temperatures also were measured at each study plot. Major trends and patterns in plant abundance were caused by the interactions of three factors: precipitation (which fluctuated between wet and dry years), vegetation association, and plant lifeform (annual, shrub, or perennial herb). Mortality and recruitment averaged $2.7 \%$ and $3.2 \%$, respectively, over a 2-year period in the Larrea-Lycium-Grayia association. Yucca Mountain has a diverse flora. Sixty-four perennial species were identified during cover censuses, although, on average, only 9 perennial species were found on each replicate line transect. A total of 191 plant species, annual and perennial, were identified in the Yucca Mountain vicinity. Species composition among vegetation associations, examined with Detrended Correspondence Analysis, was generally cohesive and verified the field identification used wnen Ecological Study Plots were initially stratified. among vegetation associations. Seasonal precipitation patterns explained approximately $58 \%$ of the variation in cover and approximately $80 \%$ of the variation in production. Species composition was significantly influenced by elevation, soil texture, slope, 6-year precipitation total, and average (12 month) maximum temperature. No threatened and endangered plant species, nor candidate species, were found.
\end{abstract}


Civilian Radioactive Waste Management System

Management and Operating Contractor

The Vegetation of Yucca Mountain: Description and Ecology

B00000000-01717-5705-00030 REV 00

March 29, 1996

Prepared by:

$\frac{\text { Ai sh B issue }}{\text { Mark B. Messing }} \frac{4 / 19 / 96}{\text { Date }}$

Science Applications International Corporation

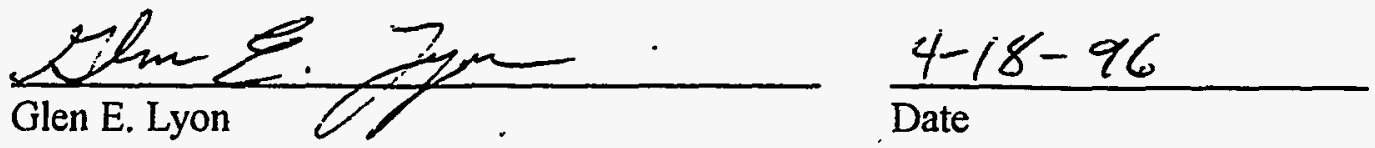

Science Applications International Corporation

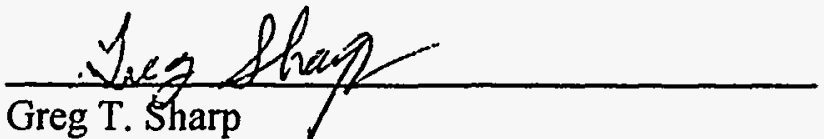

Science Applications International Corporation

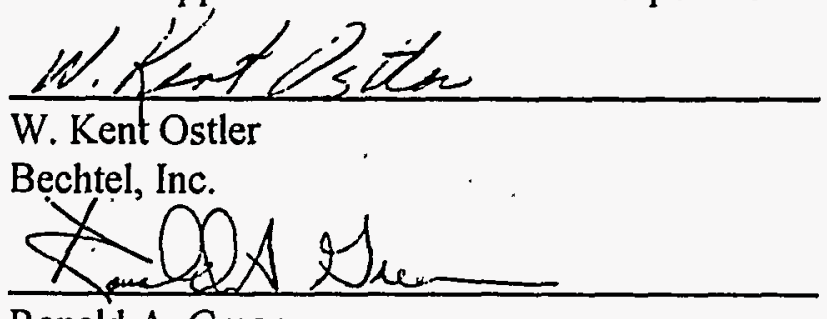

Ronald A. Green

TRW Environmenta/Safety Systems

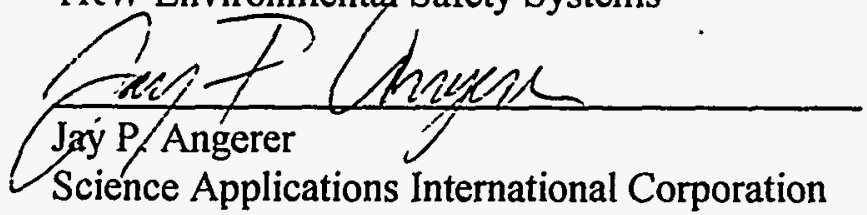

Approved by:

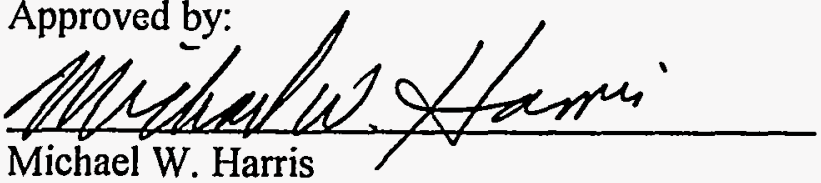

Science Applications International Corporation
$4-19-96$

Date

$\frac{4 / 24 / 96}{\text { Date }}$
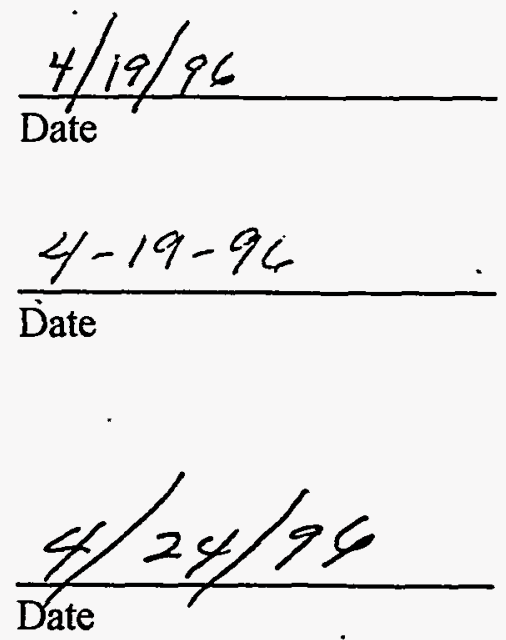


\section{ACKNOWLEDGMENTS}

Many people assisted in the design and implementation of this study. Everyone who worked for the Environmental Sciences Department of EG\&G/Energy Measurements, from 1988 until its dissolution in September 1995, contributed to this report. The names of these people are too numerous to mention individually; however, we thank every person who endured long hours, extreme temperatures, and monotonous tasks during the collection of these data: Without your individual efforts, this report would not have been possible.

The authors would like to thank Katherine Zander for assistance in map preparation. Jim Boone, Pat Lederle, Kevin Blomquist, and Von Winkel reviewed drafts and improved the final version of this report. Kevin Blomquist also lent his expertise in completing the section in this report on species of concern. Dale Ambose instructed us in the interpretation of precipitation measurements. 
INTENTIONALLY LEFT BLANK 


\section{EXECUTIVE SUMMARY}

Vegetation at Yucca Mountain, Nevada, was monitored over a six-year period, from 1989 through 1994. Yucca Mountain is located at the northern limit of the Mojave Desert and is the only location being studied as a potential repository for high-level nuclear waste. Site characterization consists of a series of multidisciplinary, scientific investigations designed to provide detailed information necessary to assess the suitability of the Yucca Mountain Site as a repository. This vegetation description establishes a baseline for determining the ecological impact of site characterization activities; it provides input for site characterization research and modeling; and it clarifies vegetation community dynamics and relationships to the physical environment. A companion study will describe the impact of site characterization on vegetation. Cover, density, production, and species composition of vascular plants were monitored at 48 Ecological Study Plots (ESPs) stratified in four vegetation associations. Precipitation, soil moisture, and maximum and minimum temperatures also were measured at each study plot.

The average percent cover (across all 48 ESPs) ranged from 15 to 28 percent during the 6-year study. Cover on individual ESPs ranged from 7 percent to 45 percent during the same period. Plant density (measured only in 1991 and 1992 on all ESPs) ranged from 62 individuals $100 \mathrm{~m}^{-2}$ in the Larrea-Lycium-Grayia vegetation associätion to 139 individuals $100 \mathrm{~m}^{-2}$ in the Lycium-Grayia vegetation assóciation. Net annual aboveground primary production, averaged across all ESPs, ranged from $0.72 \mathrm{~kg} \mathrm{ha}^{-1}$ in 1989 to $479 . \mathrm{kg} \mathrm{ha}^{-1}$ in 1992. In 1993, when production measurements were made in the Larrea-Lycium-Grayia vegetation association only, production rose to $661 \mathrm{~kg} \mathrm{ha}^{-1}$. Major trends and patterns in plant abundance were caused by the interactions of three factors: precipitation (which fluctuated between wet and dry years), vegetation association, and plant life form (annual, shrub, or perennial herb).

Mortality and juvenile recruitment averaged 2.7 and 3.2 percent, respectively, over a two-year period in the Larrea-Lycium-Grayia association. Seedling recruitment in this vegetation association averaged 9.0 percent during the same period.

Yucca Mountain has a diverse flora. Sixty-four perennial species were identified during cover censuses, although, on average, only nine perennial species were found on each replicate line transect. A total of 191 plant species, annual and perennial, were identified in the Y.ucca Mountain vicinity. Richness and diversity, measured using Shannon's diversity index, increased as the size of the area characterized increased. The converse was true of evenness, which decreased with sample area, indicating that species that dominate the cover along a $50 \mathrm{~m}$ transect do not similarly dominate throughout a vegetation association. No threatened and endangered plant species, or candidate species, were found.

The four vegetation associations used in this study had been determined at Yucca Mountain before site characterization, and were identified in the field when ESPs were initially positioned. Species composition among ESPs within vegetation associations, examined with Detrended Correspondence Analysis, was generally cohesive and verified the initial field identification. Minor discrepancies between field classification and classification using either Detrended Correspondence Analysis or Discriminant Analysis arose because of the reliance of field classification on dominant or highly visible species. 
Seasonal precipitation patterns explained approximately 58 percent of the variation in cover and approximately 80 percent of the variation in production. The amount of cover and productivity measured on each ESP was positively and significantly correlated with precipitation falling in the previous water year ( 13 to 25 -months before vegetation was measured). The carry-over of the effect of precipitation from one year to the next probably reflects biological effects as well as the cyclic climatic pattern during the six-year measurement period. Precipitation falling during the previous fall and early winter had a positive, significant correlation with cover and production, although the correlation was less than expected based on the literature. Species composition was significantly influenced by elevation, soil texture, slope, six-year precipitation total, and average (12-month) maximum temperature. 


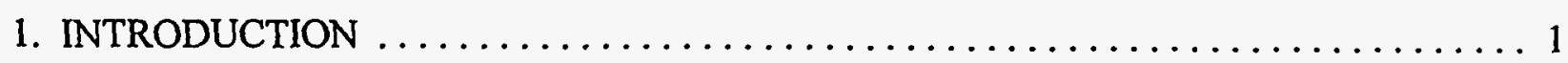

1.1 YUCCA MOUNTAIN SITE CHARACTERIZATION $\ldots \ldots \ldots \ldots \ldots \ldots \ldots \ldots$

1.2 PURPOSE AND OBJECTIVES $\ldots \ldots \ldots \ldots \ldots \ldots \ldots \ldots \ldots \ldots \ldots \ldots \ldots \ldots \ldots \ldots$

2. STUDY AREA AND PLANT ECOLOGY $\ldots \ldots \ldots \ldots \ldots \ldots \ldots \ldots \ldots \ldots \ldots \ldots$

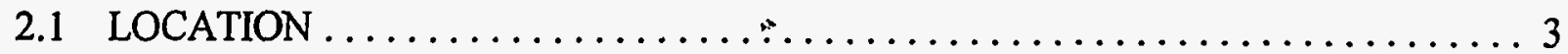

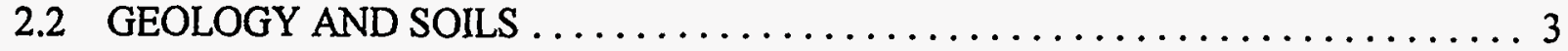

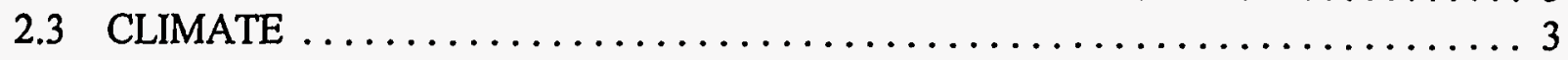

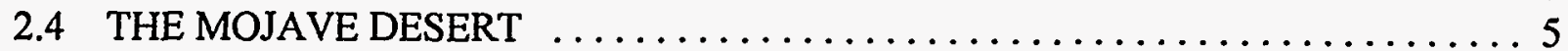

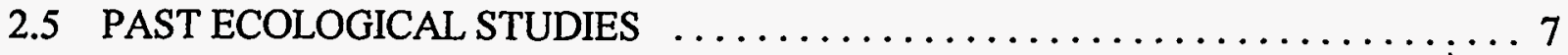

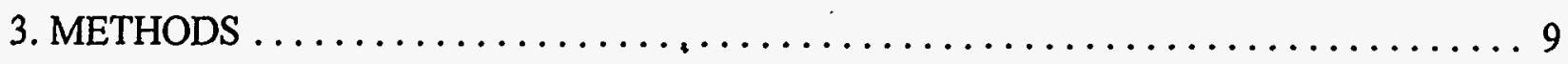

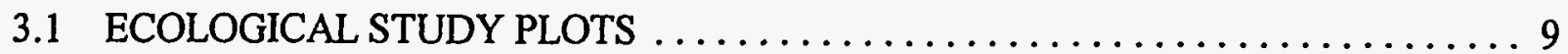

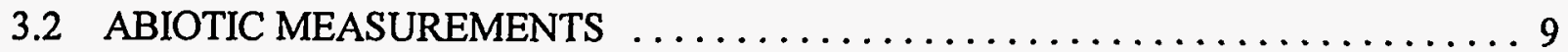

3.3 COVER . . . . . . . . . . . . . . . . . . . . . . . . . . . . . . 12

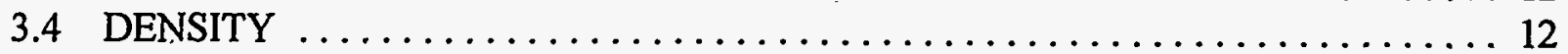

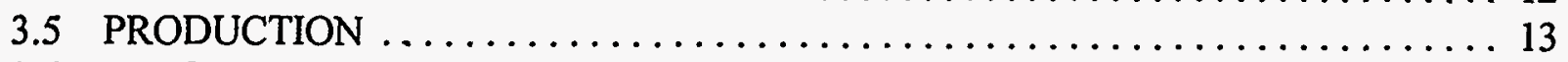

3.6 PRECIPITATION AND VEGETATIVE GROWTH $\ldots \ldots \ldots \ldots \ldots \ldots \ldots \ldots \ldots$

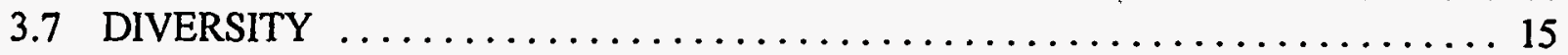

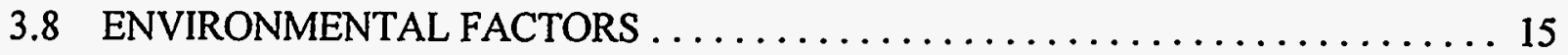

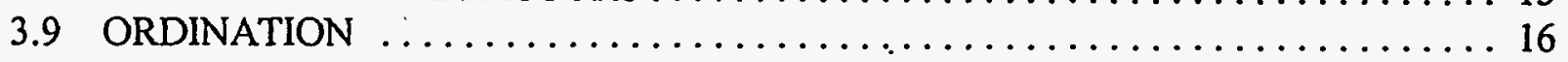

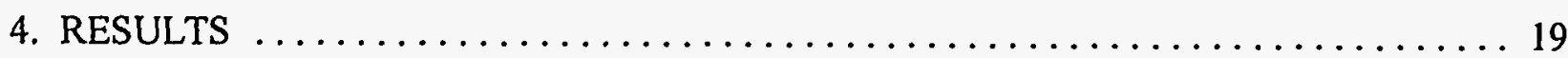

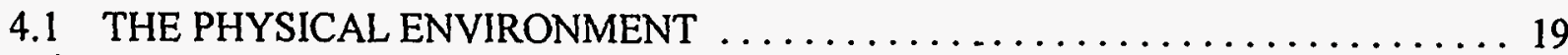

4.2 PLANT.COVER, DENSITY, AND PRODUCTION $\ldots \ldots \ldots \ldots \ldots \ldots \ldots \ldots . \ldots \ldots$

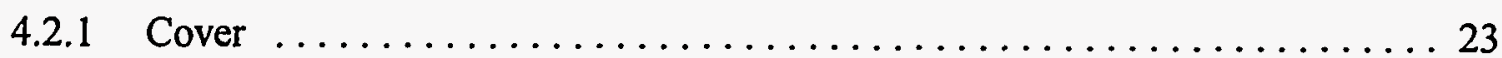

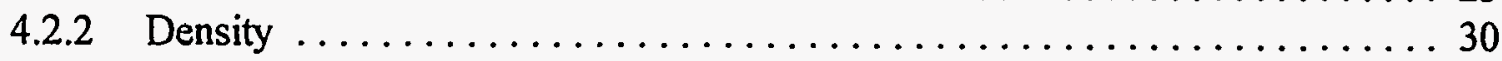

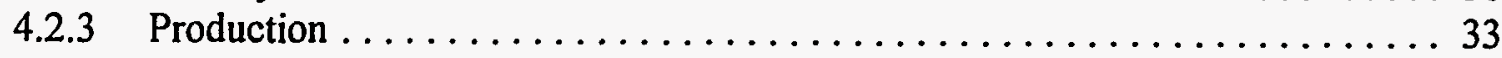

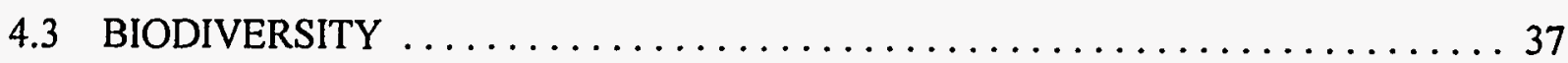

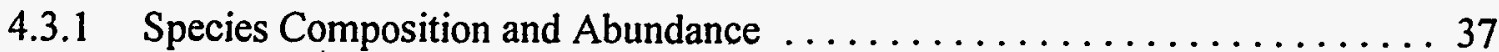

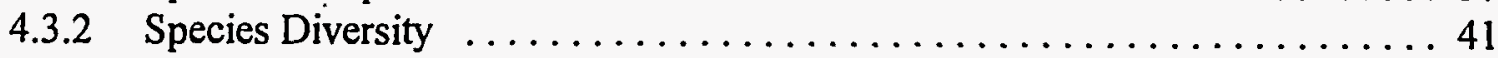

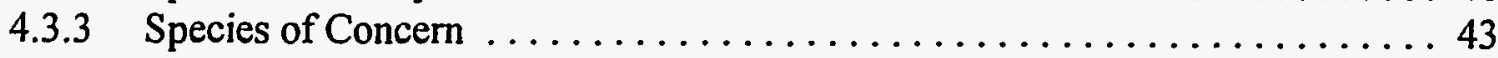

4.4 THE EFFECT OF THE PHYSICAL ENVIRONMENT ON VEGETATION $\ldots \ldots .43$

4.4.1 Species Characteristics . . . . . . . . . . . . . . . . . . . . . . . . . . 43

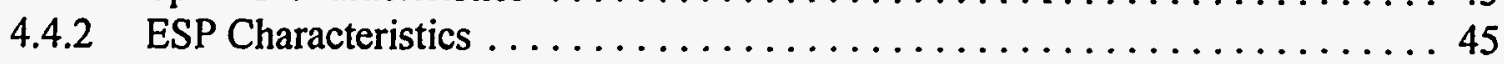




\section{CONTENTS (continued)}

4.5 THE STRUCTURE AND DISTRIBUTION OF VEGETATION ASSOCIATIONS . . 45

5. DISCUSSION

5.1 THE EFFECT OF THE PHYSICAL ENVIRONMENT ON VEGETATION $\ldots \ldots \ldots 51$

5.2 THE STRUCTURE AND DISTRIBUTION OF VEGETATION ASSOCIATIONS .. 54

5.2 .1 Previous Classification at Yucca Mountain $\ldots \ldots \ldots \ldots \ldots \ldots \ldots \ldots$

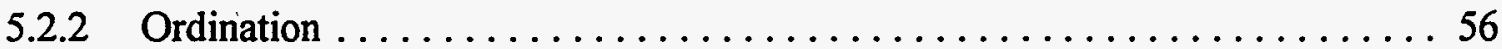

5.2 .3 Mortality and Recruitment $\ldots \ldots \ldots \ldots \ldots \ldots \ldots \ldots \ldots \ldots \ldots \ldots$

6. CONCLUSIONS ............................... 59

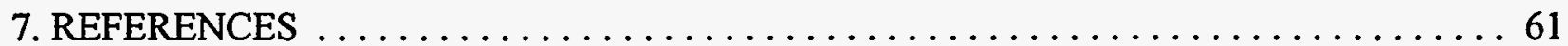

APPENDIX A - AVERAGE MONTHLY PRECIPITATION FOR EACH VEGETATION ASSOCIATION AT YUCCA MOUNTAIN, NEVADA . . . . . . . . A-1

APPENDIX B - PERCENT COVER OF VEGETATION AT YUCCA MOUNTAIN, NEVADA

APPENDIX C - PLANT DENSITY. AT YUCCA MOUNTAIN, NEVADA, 1991 TO 1993

APPENDIX D - NET ANNUAL ABOVEGROUND PRIMARY PRODUCTION AT YUCCA MOUNTAIN, NEVADA, FROM 1989 THROUGH 1994 . . . . . D-1

APPENDIX E - ' SPECIES COMPOSITION AND PERCENT COVER ON EACH ECOLOGICAL STUDY PLOT AT YUCCA MOUNTAIN, NEVADA . . . E-1

APPENDIX F - CHECKLIST OF VASCULAR PLANTS OBSERVED IN THE YUCCA MOUNTAIN, NEVADA, AREA DURING THE SITE CHARACTERIZATION EFFECTS PROGRAM 


\section{FIGURES}

Page

2-1. Location of Yucca Mountain, Nye County, Nevada. ............... 4

3-1. The Location of 48 Ecological Study Plots at Yucca Mountain, Nevada . . . . . . . 10

3-2. Schematic Diagram of an Ecological Study Plot $\ldots \ldots \ldots \ldots \ldots \ldots \ldots \ldots \ldots \ldots$

4-1. Total Water Year Precipitation (mm) for a $35-$ Year Period. . . . . . . . . . . 20

4-2. Frequency Distribution of Precipitation Over 35 Water Years. . . . . . . . 20

4-3. Water Year Precipitation for Vegetation Associations. . . . . . . . . . . . 21

4-4. Variation of Precipitation in Terms of Year, Vegetation Association, and Ecological Study Plot. . . . . . . . . . . . . . . . . . . . . . . 21

4-5. A Six-Year History of Monthly Precipitation. .................. 22

4-6. Extreme Maximum and Minimum Temperatures Among Vegetation Associations from 1991 to $1994 \ldots \ldots \ldots \ldots \ldots \ldots \ldots \ldots \ldots \ldots \ldots \ldots \ldots . \ldots \ldots$

4-7. Soil Water Content ( $\mathrm{cc} \mathrm{H}_{2} \mathrm{O} \mathrm{cc}{ }^{-1}$ soil) and Precipitation (mm) at a Representative Ecological Study Plot. . . . . . . . . . . . . . . . . . . . . . 25

4-8. Cover of Vegetation, Litter, Soil and Rock on Ecological Study Plots. . . . . . . 25

4-9. Cover Among Life Forms (Shrubs and Cacti, Perennial Forbs and Grasses, Annual Forbs and Grasses) on Ecological Study Plots. . . . . . . . . . . . . . . 29

4-10 Comparison of Total Cover, Shrub Cover, and Annual Plant Cover ......... 31

4-11. Average Density of Perennial Plants in Four Vegetation Associations at Yucca Mountain, Nevada. . . . . . . . . . . . . . . . . . . 32

4-12. Adult Mortality, Juvenile Recruitment, and Seedling Recruitment of Perennial Plants in the Larrea-Lycium-Grayia Vegetation Association . . . . . . . . . . 32

4-13. Net Annual Primary Production by Life Form During 1989 through 1994 for the Larrea-Lycium-Grayia Vegetation Association at Yucca Mountain, Nevada.

4-14. Net Annual Primary Production for Four Vegetation Associations at Yucca Mountain, Nevada 


\section{FIGURES (continued)}

Page

4-15. Average Cover for Perennial and Annual Species Measured in the Coleogyne and Larrea-Ambrosia Vegetation Associations at Yucca Mountain, Nevada ....... 39

4-16. Average Cover for Perennial and Annual Species Measured in the Lycium-Grayia and Larrea-Lycium-Grayia Vegetation Association at

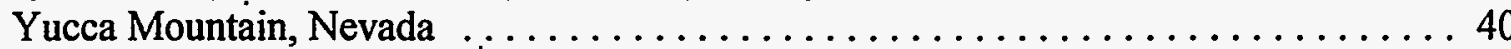

4-17. Shannon's Diversity Index, Shannon's Evenness Index, and Species Richness for Perennial Species Cover at Yucca Mountain, Nevada $\ldots \ldots \ldots \ldots \ldots \ldots 42$

4-18. Shannon's Diversity Index, Shannon's Evenness Index, and Species Richness for Perennial Species Cover Within Vegetation Associations at Yucca Mountain, Nevada

4-19. Canonical Correspondence Analysis (CCA) Biplot Showing the Relationship Between the Environmental Factors and Species Cover.

4-20. Canonical Correspondence Analysis (CCA) Biplot Showing the Relationship Between Environmental Factors and Species Composition of Each Ecological

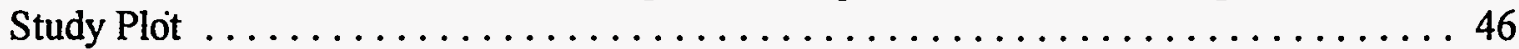

4-21. Detrended Correspondence Analysis (DCA) Ordination of 48 Ecological Study Plots from Four Vegetation Associations at Yucca Mountain, Nevada . . . . . 47

4-22. Detrended Correspondence Analysis (DCA) Ordination of Species Illustrating the Most Influential Eight Species for Each Ordination Axis 


\section{TABLES}

Page

2-1. Vegetation Associations Sampled at Yucca Mountain, Nevada $\ldots \ldots \ldots \ldots \ldots \ldots 8$

3-1. Precipitation Calendar Intervals Used to Predict Plant Growth at Yucca Mountain, Nevada .................................. 14

4-1. Analysis of Variance of Yearly Precipitation at Yucca.Mountain, Nevada ........ 22

4-2. Correlation $(r)$ Between Percent Cover or Primary Productivity, and the Total Precipitation in Five Calendar Intervals At Yucca Mountain, Nevada . . . . . . . 27

4-3. Regression Models of Precipitation Selected by the Stepwise Procedure. $\ldots \ldots \ldots 28$

4-4. Mortality and Recruitment of Each Perennial Species in the

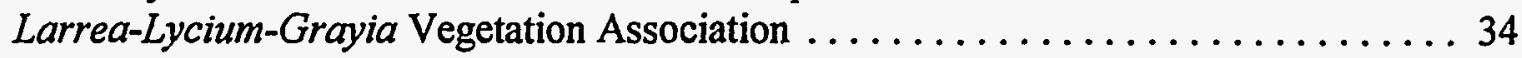

4-5. Net Annual Aboveground Primary Production $\left(\mathrm{g} \mathrm{m}^{-2}\right)$ in Four Vegetation Associations at Yucca Mountain, Nevada

5-1. Comparison of Beatley's (1976) Plant Associations with Ecological Study Plot Species Composition . 


\section{INTENTIONALLY LEFT BLANK}




\section{INTRODUCTION}

\subsection{YUCCA MOUNTAIN SITE CHARACTERIZATION}

Yucca Mountain, Nevada, is the only location being studied as a potential repository of the nation's radioactive nuclear waste. The Nuclear Waste Policy Act of 1982 and the Nuclear Waste Policy Amendments Act of 1987 directed the U.S. Department of Energy (DOE) to characterize Yucca Mountain, Nye County, Nevada, for potential development of the first geologic repository for highlevel nuclear waste. In response, DOE developed and is implementing the Site Characterization Plan, Yucca Mountain Site, Nevada Research and Development Area, Nevada (DOE 1988), which consists of a series of multidisciplinary, scientific investigations designed to provide detailed information necessary to assess the suitability of the Yucca Mountain Site as a repository.

In keeping with DOE policy to conduct its operations in an environmentally safe manner, the Site Characterization Effects Program (SCEP) was developed to monitor the possible effects of site characterization on the biological resources of the Yucca Mountain area. The SCEP focused solely on site characterization activities, and did not address long-range issues concerning nuclear waste storage. However, recognizing that nuclear waste storage issues may need to be addressed, this report gives a universal description of the Ýucca Mountain vegetation, adaptable to a wide range of future needs.

Vegetation studies started in 1989 and continued through 1994. Most site characterization activities, such as tunnel excavation, construction activity, and seismic reflection, did not begin until 1992. In addition to this description of vegetation, a second report will describe the impact of site characterization on Yucca Mountain vegetation (Hessing et al. in preparation).

\subsection{PURPOSE AND OBJECTIVES}

The vegetation description in this report has three purposes. First, it is needed to assess environmental impact, the primary purpose of the SCEP. Measurement of environmental impact requires a baseline or control, and the most accurate baseline is a description of the ecology in its preimpact state (Green 1979; Underwood 1993). Second, the vegetation description will be used in other studies; such as mapping vegetation communities, modeling ground water infiltration, or assisting land managers in measuring long-term vegetation change. Third, the description analyzes how Yucca Mountain vegetation is influenced by ecological forces such as climate, soil, or elevation. Without this basic understanding, the description cannot be used successfully for the first two purposes.

The overall objective of this study was to describe the present status of Yucca Mountain vegetation. Working objectives were to:

1. Monitor the physical environment at locations where vegetation research is conducted.

2. Measure the amount of plant cover, density, and production from three plant life forms (shrubs, perennial forbs and grasses, and annuals) and four vegetation associations during the first six years of site characterization activities. 
3. Describe the biodiversity of Yucca Mountain vegetation associations in terms of species composition, species diversity, and the presence of sensitive species.

4. Describe how climate, soils, topography and other forces in the physical environment affect the abundance and distribution of plants.

5. Describe the structure of plant communities and their distribution across the Yucca Mountain landscape.

The organization of this report follows these objectives, with each section of the results (Section 4) meeting its corresponding objective. Objectives 4 and 5 require analysis of information produced by objectives $i$ through 3 . The interpretation of these analyses is presented in the discussion sections (Section 5). Section 6 summarizes the report and highlights important findings. 


\section{STUDY AREA AND PLÁNT ECOLOGY}

\subsection{LOCATION}

Yucca Mountain is on the southwestern edge of the Nevada Test Site in Nye County, Nevada, approximately $26 \mathrm{~km}$ north of the town of Amargosa Valley (formerly Lathrop Wells) (Figure 2-1). The area is located exclusively on lands controlled by the federal government. Ownership and control of the land is divided among the DOE, which controls the eastern portion of the area through land withdrawn from the public domain for use as the Nevada Test Site; the U.S. Air Force, which controls the northwestern portion of the site through land-use permits for the Nellis Air Force Range; and the U.S. Bureau of Land Management, which controls the southwestern portion of the site as public trust lands.

\subsection{GEOLOGY AND SOILS}

Yucca Mountain lies within the arid Basin and Range geographical region. The region is characterized by linear mountain ranges that dissect alluvial piedmont valleys with rugged, complex terrain features. Yucca Mountain is a long north-south aligned volcanic ridge with a maximum elevation of $1509 \mathrm{~m}$. It slopes steeply west toward Solitario Canyon (elevation $1189 \mathrm{~m}$ ), and gradually eastward in a series of highly dissected ridges. Two large basins, Jackass Flats (elevation $1036 \mathrm{~m}$ ) and Crater Flats (elevation $915 \mathrm{~m}$ ), lie to the east and west, respectively.

The stratigraphy of the Yucca Mountain vicinity is late Miocene and early Pliocene volcanics whose topographic and structural effects partly cover the typical Basin and Range topography of the region. Soils are thin in most highland areas, while thick sequences of Quaternary alluvium fill the valleys. Soils and sediments are generally derived from volcanic rocks (primarily volcanic tuffs). It is typical to find calcic horizons either near the surface or as buried soil horizons.

Soil type and parent material are major determinants of plant species distribution in North American deserts (Smith and Nowak 1990; Wentworth 1981; Wentworth and Davidson 1987). For example, the flora of Yucca Mountain is different from the Bare Mountains, a limestone underthrust $30 \mathrm{~km}$ to the west, but similar to Skull Mountain, a volcanic flow $30 \mathrm{~km}$ to the east.

\subsection{CLIMATE}

Precipitation at Yucca Mountain is seasonal; most precipitation falls as winter and early spring rain. However, the amount of yearly rainfall fluctuated dramatically over a 35-year period from 1960 through 1995. The average water year precipitation (October through September) at Jackass Flats (approximately $18 \mathrm{~km}$ east of Yucca Mountain) was $141 \mathrm{~mm}$ over a 35-year period ranging from $51 \mathrm{~mm}$ to $313 \mathrm{~mm}$. Precipitation occurred on relatively few days during the year, and precipitation events greater than $0.20 \mathrm{~mm}$ occurred only on approximately 30 days annually on the Nevada Test Site (Eglinton and Dreicer 1984). Generally, the amount of precipitation increases with elevation (Quiring 1983). 


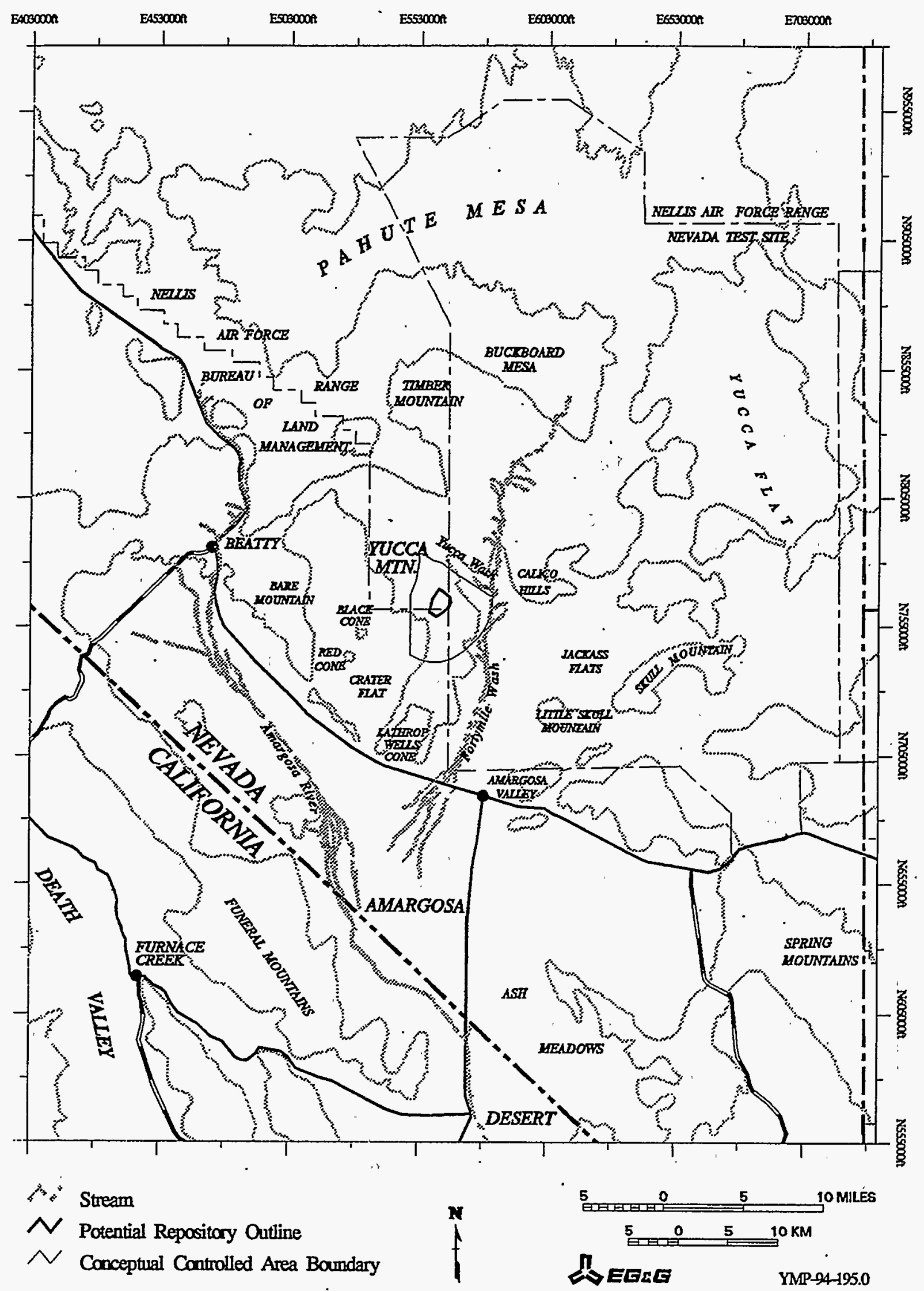

Figure 2-1. Location of Yucca Mountain, Nye County, Nevada. 
The Mojave Desert is a warm desert that occasionally experiences freezing arctic air masses during the winter (Rundel and Gibson 1996). Yucca Mountain is cool in winter, extremely hot in summer, and characterized by large daily temperature ranges. Unlike precipitation, average temperature and relative humidity are predictable. Average summer (Jully and August) temperatures have ranged from $22^{\circ} \mathrm{C}$ at Jackass Flats to $32^{\circ} \mathrm{C}$ at Fortymile Wash (DOE 1995).

\subsection{THE MOJAVE DESERT}

The greater North American Desert is subdivided into four regions based on physiognomy of vegetation, community structure, and floristics. The Mojave Desert is differentiated from the Great Basin Desert that lies immediately north of it by the -presence of "truly woody shrubs" (Shreve 1942), such as Larrea tridentata, Lycium andersonii, and Lycium pallidum. Both deserts share the same genera of "semi-shrubs with indeterminate growth" (Shreve 1942), such as Gutierrezia, Chrysothamnus, and Atriplex, although the species may change between deserts. To the south and east of the Mojave Desert, the sharp transition to Sonoran Desert is marked by the appearance of small trees, succulents, and higher diversity. Approximately one quarter of the Mojave Desert flora is endemic (Munz 1934; Shreve 1942). Climate is the driving force behind these differences in floristics. The Mojave Desert is the driest North American desert and is the most unpredictable from year to year. Furthermore, the seasonal distribution of precipitation in the late winter and early spring accentuates the unpredictability because lack of precipitation during this wet season prevents yearly growth in most species.

The flora and climate of Yucca Mountain are characteristically Mojavean (Beatley 1975 and 1976). However, because Yucca Mountain is located at the northern boundary of the Mojave Desert, vegetation on the crest and upper slopes begins a transition to Great Basin Desert flora (Beatley 1976). Beatley (1975) described transitional vegetation associations as predominately Mojavean, but influenced by one or more of three Great Basin Desert factors: precipitation, daytime temperature, or nighttime temperature.

Because of their distinctiveness, several characteristics of the Mojave Desert biome have been wellstudied by plant ecologists. Where possible, the results in this study are compared to their research. Some of the subjects that have commanded the greatest research activity from plant ecologists are described below.

Succession. Secondary succession is thought of as a directional, predictable change in species composition over time. Typical successional sequences are seen on abandoned fields that gradually come to resemble the surrounding forest. Initially, ecologists such as Shreve (1942) and Muller (1940) reported that the Mojave Desert lacked successional sequences, and that revegetation following disturbance was caused by the colonization from the adjacent climax, with no intervening seral stages. More recent research suggests that this is overly simplistic, and that indeed, successional sequences are a normal part of Mojave Desert revegetation and community development (Vasek 1980; Lathrop and Archbold 1980; Webb et al. 1987). Generally, as the successional process becomes more lengthy and complex, so does the time and uncertainty of recovery from environmental impact. Consequently, succession has some bearing on what commitment should be made to reclamation and conservation. 
Structure. The concept of structure in a community refers to the idea that presence and location of each individual is a consequence of its interaction with other species, its interaction with the physical environment and microenvironment, and its own ecological niche. From a broad perspective, the ecological literature suggests that the visual monotony of desert plant communities may obscure a high degree of ecological structure. For example, in a study of the Chihuahuan Desert, Silvertown and Wilson (1994) found evidence for positive associations among some species, competitive exclusion by other species, and a distinctive patch structure indicating interspecific facilitation during recruitment. An example of differences in ecological niche among species that have the same general physiognomy was provided by Goldberg and Turner (1986). They found that most upland Sonoran Desert shrub species could be categorized into two groups based upon life history characters. The dichotomy in life history characters probably extends to the Mojave Desert. For example, Larrea tridentata is extremely long lived (Vasek 1980), while other shrubs, such as Chrysothamnus viscidiflorus and Hymenoclea salsola, appear to be short-lived colonizers (Carpenter et al. 1986; Webb et al. 1987). Underground niche differences among desert species probably add to community structure. For example, root systems of Ericameria cooperi and $C$. teretifolius (both common at Yucca Mountain) exploit different soil horizons (Manning and Barbour 1988), and the pattern of root growth by Ambrosia dumosa may be affected by the presence of Larrea roots (Mahall and Calloway 1991).

Annuals. In terms of both biomass and number of species, annuals are an important component of all North American deserts. The Mojave Desert is distinguished from the Sonoran and Great Basin Deserts by its abundance of winter annuals and its depauperate summer annual community of just eight species (Beatley 1969a). The diminutive size of most annuals belie their great productivity during wet years; and their importance as a seed source for desert rodents and ants (Beatley 1969b; Reichman and Price 1993; Soholt 1973).

Vegetation Change and Paleohistory. The history of vegetation in the Great Basin and Mojave Deserts over the last 20,000 years has been described by analyzing pack rat middens (Spaulding and Graumlich 1986; Spaulding 1990; Van Devender et al. 1987). Present Mojave Desert vegetation dates from approximately 8,000 years before present. Vasek (1980) presented evidence that the life span of $L$. tridentata may reach 10,000 years, and concluded that many of the individuals present in the Mojave Desert were the original colonizers at the beginning of the last interglacial epoch.

In addition to its relatively recent origin, Mojave Desert vegetation also fluctuates in response to shorter, less intense climatic cycles, as well as episodic erosion and alluvial deposition. Cole and Webb (1985) describe elevational shifts in the distribution of Coleogyne ramosissima between 1400 A.D. and the present, and both McAuliffe (1991 and 1994) and Webb et al. (1987) suggest that structure of the plant community reflects the age of the underlying alluvial deposits, which may be relatively young. In short, the Mojave Desert is a young desert that may not have achieved equilibrium.

On a shorter time scale of 10 to 100 years, Mojave Desert plant communities remain constant, but individuals within the community undergo continual replacement. This has been measured with periodic censuses by Beatley (1980), and it has been documented photographically by Webb et al. (1987). Because of the dynamics of Mojave Desert vegetation, Webb et al. (1987) and Turner (1990) caution against designating undisturbed vegetation as "climax," a suggestion that will be followed in the remainder of this report. 
Vegetation Associations. A vegetation association is an assemblage of species with a distinctive physiognomy and dominance hierarchy (Barbour et al. 1980). Based on Beatley's (1976) classification, O'Farrell and Collins (1984) ídentified and mapped four vegetation associations at Yucca Mountain that were subsequently used in the present study. However, O'Farrell and Collins also found that these associations, described in Table 2-1, were indistinct. They reported that the most common species at Yucca Mountain often differed from Beatley's description of the same association elsewhere on the Nevada Test Site, hence the poor correspondence between the association name and the dominant species in Table 2-1. O'Farrell and Collins also suggested that, despite the complex species composition of each association described by Beatley, the four associations could be classified simply by the dominance or lack of dominance of three species (C. ramosissima, L. tridentata, and Ambrosia dumosa) according to the scheme shown in Table 2-1.

Beatley (1976) described the vegetation associations found on the Nevada Test Site as floristically diverse within each association and floristically variable among sites within the same association. Her classification was qualitative, and quantitative verification of her classification was not presented (or needed, given her objectives). Complementing Beatley's qualitative approach, El-Ghonemy et al. (1980a-c) described vegetation associations in the Mojave Desert portion of the Nevada Test Site using quantitative methods. Unfortunately, these authors make no attempt to show the equivalence between their vegetation -associations and Beatley's, but it is clear that the two classification systems are often different. Like Beatley, El-Ghonemy et al. (1980a) found that associations were not always distinct; consequently, 10 percent of their stands were classified as transitional or ecotonal. The presence of two different classifications, as well as the recognition that not all vegetation can be unambiguously classified, creates uncertainty for future studies that use the concept of the association in Mojave Desert vegetation.

Whether or not plant communities form discrete units across the landscape is a complex and controversial subject in plant ecology (Barbour et al. 1980); however, it is relevant to future vegetation research at Yucca Mountain. When species are found in predictable associations that appear repeatedly across the landscape-regardless of theoretical considerations about the cause of these associations-predictions and models of the landscape can be made from a limited sample. The potential power of the vegetation association concept rests in part upon the accuracy with which associations have been described. Based on the vegetation description in this report, infiltration models, biodiversity, or habitat loss can be calculated for the entire Yucca Mountain landscape.

\subsection{PAST ECOLOGICAL STUDIES}

The present study adds to a wealth of information that has accumulated on the plant ecology of the Nevada Test Site. During the International Biological Program, from 1971 to 1976, the Nevada Test Site became the focus of extensive research on the Mojave Desert ecosystem (Wallace 1980). Much of this research was performed at Rock Valley, $40 \mathrm{~km}$ southeast of Yucca Mountain, and has recently been integrated into a thorough description of ecological research on the Nevada Test Site (Rundel and Gibson 1996)..

From 1980 to 1986, during preliminary site investigation of Yucca Mountain, a literature search (Collins et al. 1981 and 1982) and plant ecology studies (Medica et al. 1981; O'Farrell and Collins 1984) began the process of describing Yucca Mountain vegetation. The goals of the field studies 
Table 2-1. Vegetation associations sampled at Yucca Mountain, Nevada. Classification is based on Beatley (1976) and O'Farrell and Collins (1984). Dominant species are the perennials with the greatest mean cover.

\begin{tabular}{|c|c|c|c|c|}
\hline & \multicolumn{4}{|c|}{ Vegetation Association } \\
\hline & Coleogyne & Larrea-Ambrosia & Lycium-Grayia & $\begin{array}{l}\text { Larrea-Lycium- } \\
\cdot \quad \text { Grayia }\end{array}$ \\
\hline Desert & Transition & Mojave & Transition & Mojave \\
\hline $\begin{array}{l}\text { Soil and } \\
\text { Topography }\end{array}$ & $\begin{array}{l}\text { Shallow, gravelly } \\
\text { soils of upper } \\
\text { bajadas, frequently } \\
\text { containing limestone. }\end{array}$ & $\begin{array}{l}\text { Deep, loose sandy soil } \\
\text { lacking surface } \\
\text { pavement on lower } \\
\text { bajadas and basins. }\end{array}$ & $\begin{array}{l}\text { Sandy soil, from } \\
\text { either limestone or } \\
\text { volcanic parent } \\
\text { material, on upper and } \\
\text { lower bajadas. }\end{array}$ & $\begin{array}{l}\text { Sandy loam soil, } \\
\text { frequently of volcanic } \\
\text { origin, on higher } \\
\text { bajadas and valleys. }\end{array}$ \\
\hline $\begin{array}{l}\text { Physiognomy } \\
\text { (O'Farrell and } \\
\text { Collins 1984) }\end{array}$ & Coleogyne dominant. & $\begin{array}{l}\text { Larrea and Ambrosia } \\
\text { dominant. }\end{array}$ & No dominant. & Larrea dominant. \\
\hline $\begin{array}{l}\text { Dominant } \\
\text { Species at Yucca } \\
\text { Mountain }\end{array}$ & $\begin{array}{l}\text { Coleogyne } \\
\text { ramosissima } \\
\text { Ambrosia dumosa } \\
\text { Ephedra nevadensis } \\
\text { Lycium pallidum }\end{array}$ & $\begin{array}{l}\text { Ambrosia dumosa } \\
\text { Larrea tridentata } \\
\text { Menodora spinescens } \\
\text { Lycium pallidum }\end{array}$ & $\begin{array}{l}\text { Ephedra nevadensis } \\
\text { Grayia spinosa } \\
\text { Eriogonum } \\
\text { fasciculatum } \\
\text { Lycium andersonii }\end{array}$ & $\begin{array}{l}\text { Larrea tridentata } \\
\text { Ephedra nevadensis } \\
\text { Ambrosia dumosa } \\
\text { Krameria erecta }\end{array}$ \\
\hline
\end{tabular}

were to quantitatively describe the flora within the 70 -square $\mathrm{km}$ area surrounding the potential repository site, to determine whether sensitive species or unique habitats were present, and to describe vegetation associations. Using Beatley's (1976) seminal description of Nevada Test Site vegetation, O'Farrell and Collins (1984) found that Yucca Mountain vegetation could be generally classified into four associations. Beatley described associations after the dominant species (Table 2-1) as follows: COL (Coleogyne ramosissima), LA (Larrea tridentata/Ambrosia dumosa), LG (Lycium andersonii, Grayia spinosa), and LLG (L. tridentata, Lycium andersonii, and G. spinosa). Acronyms are used to distinguish an entire vegetation association from a single species. Use of the name LG follows O'Farrell and Collins (1984), who also referred to this association as "mixed transition"; however, this association most closely matches Beatley's (1976) GL (G. spinosa-Lycium andersonii) association.

Beginning in 1988, numerous ecological studies were initiated to answer specific questions about the effects of the site characterization process on biological resources, and to establish baseline site descriptions. While most of these studies are still in progress, several have been published. Angerer et al. (1994) and Gabbert et al. (1995) dèscribed secondary succession and calculated succession rates of common species. Niles et al. (1994 and 1995) made a detailed floristic collection and checklist of the greater Yucca Mountain area. Measurements of water use and evapotranspiration by dominant shrubs were made by Leary (1990) and Smith et al. (1995). Schultz and Ostler (1995a and 1995b) described the effects of drought and drought recovery on individual species as well as vegetation associations. 


\section{METHODS}

\subsection{ECOLOGICAL STUDY PLOTS}

The sampling unit for this study was an Ecological Study Plot (ESP), a 4 ha (200 m x $200 \mathrm{~m}$ ) permanent, unfenced plot. To ensure representative sampling from the full range of vegetation at Yucca Mountain, sampling was stratified within four vegetation associations (Figure 3-1). The use of vegetation associations decreases random variability among ESPs, and increases inference to all similar vegetation on the Yucca Mountain landscape. However, because they were stratified, ESPs are not a completely random sample of all vegetation at Yucca Mountain. Vegetation associations were determined visually at the inception of the SCEP, based on descriptions by O'Farrell and Collins (1984) and Beatley (1976) (Table 2-1).

Within each association, ESPs were randomly located, subject to constraints with respect to construction activity (Green et al. 1991). These constraints were necessary because ESPs were used concurrently in a second study on the impacts of site characterization activities on vegetation (Hessing et al. in preparation).

This report combines information from both before (1989 through 1991) and during site characterization activity (1992 through 1994). Including measurements made during site characterization as a baseline or control from which future vegetation change can be determined could affect the accuracy of the baseline. Three reasons justify use of during-impact information to create a baseline. First, ESPs were not physically disturbed by construction activity, although half of all ESPs were deliberately located next to disturbances. Plants on these ESPs could have been indirectly affected by fugitive dust, runoff, noise, and exotic species introductions. Second, anecdotal observations and a preliminary statistical analysis (Hessing et al. in preparation) indicate that the effect of disturbance is small and insignificant. Third, excluding data collected adjacent to site characterization activity would halve the sample size and decrease the accuracy of this quantitative description. Therefore, the value of during-impact information far outweighs the minor problems with its interpretation.

\subsection{ABIOTIC MEASUREMENTS}

A weather monitoring station was established along the boundary of each ESP (Figure 3-2). Each station consisted of one maximum-minimum thermometer housed in an open-air shelter, three electrical resistance sensors to measure soil moisture, and one rain gauge.

The soil moisture sensors were buried two meters from the shelters. The cells were placed into an undisturbed soil profile at depths of $15 \mathrm{~cm}, 30 \mathrm{~cm}$, and, if soil depth permitted, $45 \mathrm{~cm}$. Resistance measurements (Amer et al. 1994) were used to determine volumetric soil water (grams of water per cubic centimeter, $\mathrm{g} \mathrm{cc}^{-3}$ ). Calibration methods followed that of Roundy et al. (1991). Rain gauges were attached to a metal fence post next to each shelter. The rain gauge consisted of a measuring tube inside an overflow canister and a screened collection funnel on top. During winter, the cylinder and funnel were removed to allow snowfall to be measured. Mineral oil was placed in the measuring tube to decrease evaporation, and ethylene glycol was added to the mineral oil during the winter to inhibit freezing. 


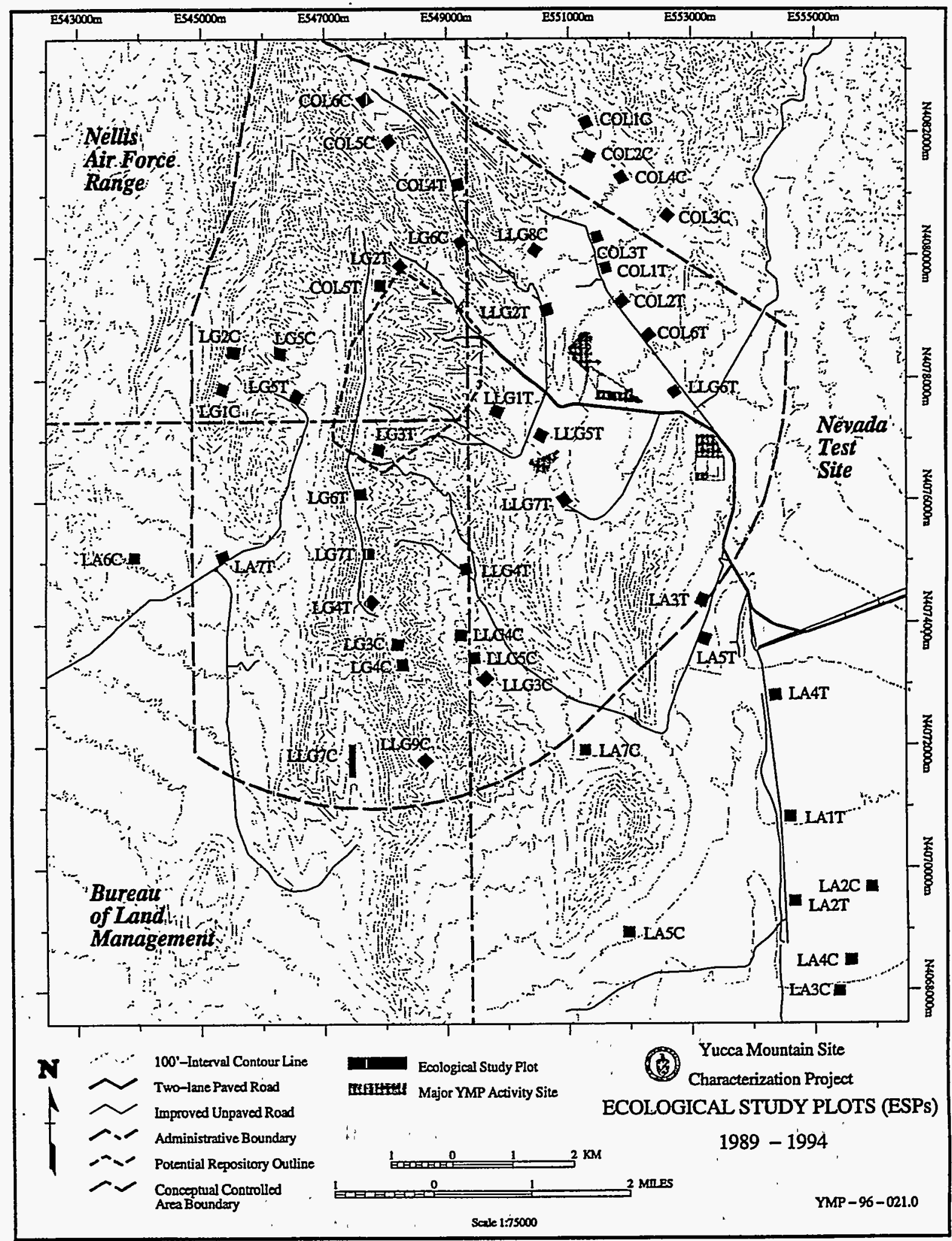

Figure 3-1. The location of 48 Ecological Study Plots (ESPs) used in the Site Characterization Effects Program at Yucca Mountain, Nevada. 


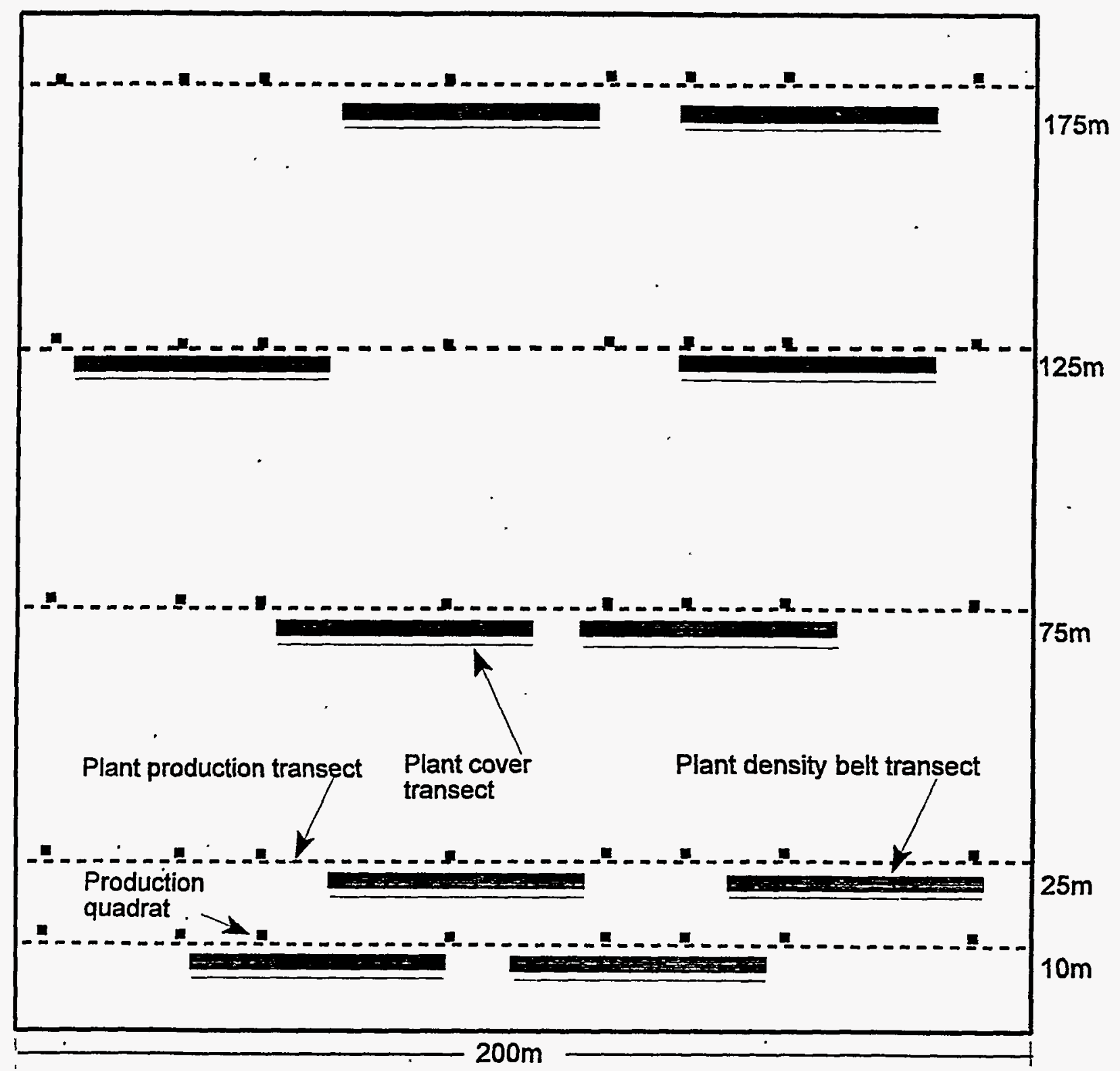

Figure 3-2. Schematic diagram of an Ecological Study Plot (ESP) used to sample vegetation and weather during the Site Characterization Effects Program (SCEP) at Yucca Mountain, Nevada. 
Data were collected from the 48 weather stations from 1991 to 1994 . Each weather station was sampled weekly from March through May and monthly from June through February. During wet years, weekly sampling continued into the summer until the soil was dry. Precipitation, maximum temperature, minimum temperature, soil temperature, and soil moisture were measured during each collection period. Because weather stations were not installed at ESPs until 1991, precipitation prior to this period was estimated from the five U.S. Geological Survey weather stations in the Yucca Mountain area. Therefore, from 1988 through 1990 neighboring ESPs within a vegetation association received the same estimate of precipitation.

To assess the magnitude and pattern of long-term fluctuations in precipitation at Yucca Mountain, a 36-year monthly history of precipitation was obtained for the U.S. Geological Survey 4JA weather station in Jackass Flats, approximately $12 \mathrm{~km}$ from the center of the Yucca Mountain ecological research area. From these data, the total precipitation in 35 water years-the period between October 1 and September 30-was calculated. Station 4JA receives the same pattern, but slightly less precipitation than ESPs (U.S. Department of Interior 1995).

\subsection{COVER}

Sampling techniques were selected based on their applicability to arid conditions, repeatability, and acceptance by the scientific community. Ground cover was measured using the point method with a sighting telescope (Bonham 1989). One hundred points were sampled along two 50-m transects at four evenly spaced distances from one side of the plot. Living plants were identified to species, and litter and substrate were categorized. Subsampling was randomized by determining the starting point of each transect with a random number (Figure 3-2). On half of the ESPs, the number of transects was increased from eight to ten to incorporate the experimental design used in Hessing et al. (in preparation). Living plants were identified to species (Kartesz and Pankhurst 1994), dead and unrooted organic material was classified as litter, and inorganic material was categorized as rock $(>25 \mathrm{~cm})$, cobble $(\leq 25 \mathrm{~cm},>8 \mathrm{~cm})$, gravel $(\leq 8 \mathrm{~cm},>0.5 \mathrm{~cm})$, or bare. At each point, measurement was restricted to the first (highest) plant to fall under the cross hairs of the sighting telescope. Therefore, cover is an accurate measure of ground cover, but it is a conservative estimate of the amount of vegetation as well as the proportion of annuals and subshrubs to erect shrubs.

\subsection{DENSITY}

Plant density was sampled in belt transects located adjacent to cover transects (Figure 3-2). All perennial plants rooted in the $2 \mathrm{~m} \mathrm{x} 50 \mathrm{~m}$ belt were identified to species, and measured for canopy volume (height $\mathrm{x}$ length $\mathrm{x}$ width). Location of each perennial was mapped so that it could be located in subsequent censuses. Density was censused during 1991 and 1992 in all vegetation associations, and during $1993^{\circ}$ in the LLG association. The density of perennial seedlings was estimated by counting the number of seedlings in a random subset of five, one-square meter quadrats in 1992 and 1993.

Mortality and Recruitment. Mortality, juvenile recruitment, and seedling recruitment were measured in the LLG vegetation association in 1992 and 1993. Mortality was defined as the death or disappearance of a previously mapped perennial plant. Juvenile mortality was defined as the appearance of a previously unmapped perennial plant, at least one year old. Seedling recruitment was defined as the appearance of perennial plants less than one year old, censused in five, 
four-square meter quadrats within each belt transect. Mortality and recruitment were measured in LLG vegetation because the three years of density censuses in this association provided two consecutive years for estimation of population dynamics.

Since the number of plants dying or becoming established is a function of the number of plants of that species in the population, mortality and recruitment were measured as a percentage of the population size of that species in the previous year.. Expressing mortality and recruitment as a percent made it possible to compare rates among species with different densities or among areas with different plant densities. Uncommon species (density $<.2100 \mathrm{~m}^{-2}$ ) give the false appearance of fluctuating between low and high values of mortality and recruitment and were excluded from analysis.

\subsection{PRODUCTION}

Net annual aboveground primary production (production) was measured by removing, drying, and weighing leaves, flowers, seeds, and stems formed during the current growing season from all plants within a one-square meter sample quadrat. Shrubs, annuals, and perennial forbs and grasses were measured separately. When less than 100 percent of a specific life form could be removed, the percent of the production remaining was estimated to correct the estimate.

Production on all 48 ESPs was measured in only four of the six years of the SCEP, from 1989 to 1992. In 1993 production was measured in the LLG association only. In 1994 annual, perennial grass, and perennial forb production (but not shrub production) was measured in the LLG association. Production estimates were limited to the LLG association starting in 1993 because most site characterization activities were occurring in this association.

To estimate production from an entire ESP, 8 sample quadrats were randomly located on transects adjacent to each of the 4 or 5 cover transects (Figure 3-2), for a total of either 24 or 32 sample quadrats. Production was sampled from May through July. Because some desert plants lose their leaves before the onset of summer, or actively grow during the summer following precipitation, production was probably underestimated.

To maximize the area sampled and to minimize sampling time and effort, production was estimated on additional quadrats using a modified version of the relative-weight-estimate method (Hutchings and Schmautz 1969). Two one-square meter estimate quadrats were placed adjacent to the left and right sides of each sample quadrat, and the production of each life form in these quadrats was estimated as a percentage of the production in the harvested (middle) quadrat. If a life form was absent from the sample quadrat, or poorly represented (500 percent less production than an estimate quadrat), production from that life form was harvested from the estimate quadrat.

Harvested quadrats were never resampled in subsequent years. Once all the possible sample quadrat positions on production line transects had been used. (which usually took two years), new production line transects were established $1 \mathrm{~m}$ beyond the previously used line.

Production samples of each life form were placed in paper bags, air dried, and then oven dried at $60^{\circ} \mathrm{C}$ to $65^{\circ} \mathrm{C}$ for 24 to 48 hours. To obtain adjusted sample weights, the average oven-dried sample weight was divided by the percent harvested. Each adjusted sample weight was then multiplied by 
the two associated sample quadrat estimates to convert estimates into weights. All production results are presented in $\mathrm{g} \mathrm{m}^{-2}$.

\subsection{PRECIPITATION AND VEGETATIVE GROWTH}

Multiple linear regression was used to explore relationships between precipitation and vegetative growth. Vegetative growth, the dependent variable, was taken from yearly censuses of vegetative cover and production on each ESP. While productivity is the more appropriate measure of vegetative growth (Milchunas et al. 1994; Robertson 1988), it was only measured in four of the six years of site characterization. The total amount of vegetation was analyzed, as well as the separate contributions of shrubs and annuals. To determine the cumulative effect of rainfall on vegetative growth, precipitation was summed over the five calendar intervals in Table 3-1, and the calendar intervals were used as independent variables in multiple regression analyses.

Squared functions of the calendar interval variables (Table 3-1) were also calculated and included in the multiple regression (Milchunas et al. 1994), but interactions were not. Inclusion of a squared variable in the regression model indicates that the variable has a curvilinear effect on the dependent variable. Stepwise regression was used to select a regression model that explained the most variability in cover or productivity using the smallest subset of variables. Independent variables were included in the model only if they added significantly $(P<0.05)$ to the existing model. Mallow's $\mathrm{C}_{\mathrm{p}}$ statistic (Weisberg 1980) was also used to select models that provided reasonable explanations of plant growth using a small subset of variables.

Table 3-1. Precipitation calendar intervals used in correlation and regression analysis to explore relationships between precipitation and plant growth at Yucca Mountain, Nevada.

\begin{tabular}{|c|c|l|}
\hline Calendar Interval & $\begin{array}{c}\text { Time Period (using 1989 as an } \\
\text { example). }\end{array}$ & \multicolumn{1}{|c|}{ Explanation } \\
\hline SPR_WIN & $12 / 1 / 88-4 / 31 / 89$ & Late winter and early spring precipitation. \\
\hline FALL_WIN & $10 / 1 / 88-12 / 31 / 88$ & $\begin{array}{l}\text { Autumn and early winter precipitation. Precipitation } \\
\text { during this period was described by Beatley (1974b) } \\
\text { as being crucial to growth the following spring. }\end{array}$ \\
\hline GROW_YR & $10 / 1 / 88-4 / 31 / 89$ & $\begin{array}{l}\text { The calendar interval encompassing both SPR_WIN } \\
\text { and FALL_WIN. }\end{array}$ \\
\hline WATER_YR & $10 / 1 / 88-10 / 1 / 89$ & $\begin{array}{l}\text { Precipitation from the full, 12-month period most } \\
\text { indicative of plant growth. }\end{array}$ \\
\hline PREV_YR & $10 / 1 / 87-10 / 1 / 88$ & Precipitation from the previous WATER_YR. \\
\hline
\end{tabular}

Two clarifications about the data are warranted. While spatial variability is adequately controlled for by the 48 ESPs, yearly variation is limited to only four or six years. Hypothesis tests based on the total sample size of 271 may exaggerate the power of the regression. To avoid this potential problem, the order of selection of the independent variables is emphasized, rather than significance tests. Second, precipitation falling in each calendar interval is an estimate, since rain gauges were not measured at the exact beginning and end of each interval. 


\subsection{DIVERSITY}

Diversity measurements consist of two major components: species richness (the number of species present) and species evenness (proportional equivalence among species) (Margurran 1988). Shannon's evenness (the equitability of species in a sample) was calculated as follows:

$$
\text { Evenness J }=\frac{\sum_{i=1}^{s} p_{i} \ln p_{i}}{\ln s}
$$

where $s=$ the number of species

$\mathrm{p}=$ the proportion of individuals of the ith species or the abundance of the ith species expressed as a proportion of the total cover or density

$\ln =$ the natural logarithm

Shannon's diversity index combines richness and evenness into one general diversity index:

Diversity $H^{\prime}=\sum_{i=1}^{s} p_{i} \ln p_{i}$

where $s=$ the number of species

$p=$ the proportion of individuals or the abundance of the ith species expressed as a proportion of the total cover or density.

ln $=$ the natural logarithm

An assumption of the Shannon Diversity index is that species are randomly sampled from an "infinitely large" population and that all species that occur in the plant.community are included in the measured sample. Kent and Coker (1992) suggest that the last assumption is difficult to meet because most plant ecologists do not know prior to sampling, and sometimes after sampling, what the complete species composition of the sampling unit is. This is the case with this study. Cover measurements were used to calculate diversity indices; although it was known that not all species occurring within an ESP had been censused. However, diversity indices provide a means of comparing sampling units in the present and future.

\subsection{ENVIRONMENTAL FACTORS}

The purpose of this analysis was to determine what abiotic ecological factors determine the distribution and abundance of perennial plant species. The factors investigated were weather (average low and high temperatures, and water year precipitation), topography (slope, aspect, and elevation), and lithography. At each ESP, a soil pit was dug to determine soil horizonation, texture, structure, consistency, plasticity, coarse fragment percentage, color, $\mathrm{pH}$, effervescence, concretions, and root distribution. 
Canonical correspondence analysis was used to examine the relationships between individual species and environmental variables (ter Braak 1986) using the species distribution and abundance measurements from perennial plant cover (averaged over six years) from each ESP. Canonical correspondence analysis first ordinates plant species to display their similarity to each other, and then uses multiple regression to correlate environmental variables with species composition (Kent and Coker 1992). Both DCA and canonical correspondence analysis can be reoriented to ordinate either ESPs (R-type ordination) or species (Q-type ordination) and show their relationship to environmental variables (Pielou 1984).

Canonical correspondence analysis was performed using the CANOCO software program (ter Braak 1992). Because many of. the environmental variables are autocorrelated, analysis was limited to variables that correlated highly with the canonical correspondence ordination, and that explained unique patterns of variation in the ordination (i.e., had nonoverlapping axes). The five environmental variables included in the analysis were elevation, soil sand content, water year precipitation, slope, and monthly average high temperature. CANOCO tests the significance of the species-environment (or ESP-environment) correlation using a Monte Carlo permutation test (ter Braak 1986).

\subsection{ORDINATION}

The strength of the vegetation association concept at Yucca Mountain was analyzed with ordination, a commonly used method of comparing species composition among vegetation samples (Gauch 1982). Ordination first extracts the variation in species composition among sites and then combines that information into several synthetic axes that hold most of the original variation. The axes are graphed, and groups of sites with similar graph locations are assumed to belong to the same vegetation association.

Standard methods of ordinating vegetation, described by Pielou (1984) and Gauch (1982), were used to represent the 48 ESPs on the basis of their species composition. Several forms of ordination have been developed, but Gauch and Pielou recommend Detrended Correspondence Analysis (DCA), and this technique was used in this study. DCA ordination was computed using MVSP 2.1 software (Kovach 1993).

Input data for the ordination was relative cover of perennials (shrubs, grasses, and forbs) in 1992. Cover was transformed using Aitchison's (1986) log-ratio (the default percent transform in MVSP). Relative cover was analyzed to emphasize species composition while minimizing the difference in plant cover from one ESP to another. The relative cover of all perennial species at an ESP adds to 100 .

An additional analytical technique, discriminant analysis (Manly 1986), was used to test the statistical significance of the classification system. Discriminant analysis is difficult to apply to community ecology because of the non-normal distribution of most data (most species are missing from each site). This problem was circumvented by extracting information from all 41 species into a few principal component axes, and then using the normally distributed principal component axes in the discriminant analysis.

The vegetation association of several test plots located throughout the Yucca Mountain area was classified by "projecting" it onto the DCA ordination. Projection of each test plot was performed 
by multiplying each species' cover by the corresponding species' eigenvector from the DCA ordination. Classification by projection was also performed-using discriminant analysis. Discriminant analysis classification has the advantage of choosing the single best vegetation association for a test plot, and DCA, because it is a graphical technique, has the advantage of showing the relationship between a test plot and all four vegetation associations. Projection is useful in vegetation mapping, where data can be collected from an unmapped site and plotted to show its similarity to the 48 originally classified ESPs. 


\section{INTENTIONALLY LEFT BLANK}




\section{RESULTS}

\subsection{THE PHYSICAL ENVIRONMENT}

Precipitation: Long-term Pattern. Precipitation over the last 35 water years oscillated between wet and dry years (Figure 4-1). The distribution of precipitation among years did not follow a normal distribution (Figure 4-2) (Kolomogorov-Smirnoff test; $\mathrm{p}<0.001$ ). In other words, extreme precipitation years, either dry or wet, are just as common as moderate years.

Yearly precipitation, both estimated (1988 to 1990) and actual (1991 to 1994), was extremely variable (Figure 4-3). The climate during this period was cyclic, a series of dry years followed by a series of wet years. Water year precipitation recorded at each ESP was significantly correlated with precipitation from the previous year $(r=0.29, \mathrm{p}<0.001, \mathrm{n}=271)$. This unexpected result may have been an artifact of the six-year viewing frame, but it is also possible that the correlation reflected the boom and bust pattern of precipitation on the Mojave Desert. This pattern was recognized by Houghton et al. (1975) as typical of southern Nevada.

An additional source of variation was that of monthly pattern (Figure 4-4). Even when the total precipitation during the period of plant growth, from December through April, was similar between years, the monthly distribution of precipitation differed considerably. For example, in 1991 February was dry and March was wet; whereas, in 1994, a year with total precipitation similar to 1991, precipitation was equally distributed among all growing season months. Two additional water years with similar total precipitation, yet different monthly patterns, were 1992 and 1993. The wet season started earlier in 1993, when precipitation from November through January was $84 \mathrm{~mm}$ greater than in 1992. However, the wet season lasted longer in 1992, when precipitation from February through April was $50 \mathrm{~mm}$ greater than in 1993. Despite the variability in seasonal pattern, the first three months of the calendar year were usually the wettest. January, February, and March of 1992 received a total of $151 \mathrm{~mm}$ of precipitation, and the same time period in 1993 received $155 \mathrm{~mm}$ of rainfall. Monthly averages for each association are shown in Appendix A.

Major precipitation events can happen at any time of year. In $1989,22.5 \mathrm{~mm}$ of precipitation fell in the usually dry month of August. However, years often pass with no single outstanding precipitation event (e.g., 1990 and 1994).

Precipitation: Spatial Variation. In addition to yearly fluctuation, precipitation also showed considerable spatial variation (Figure 4-3). The COL and LLG associations were wettest, and the LG and LA were the driest. Because vegetation associations receive different amounts of precipitation (Figure 4-3), and because there was so much random variation from ESP to ESP during any rainfall, an analysis of variance was used to determine the relative size of variation caused by years, vegetation associations, and ESPs. Differences in precipitation among vegetation associations were highly significant (Table 4-1). While there was no valid hypothesis test of the variation among ESPs (Hessing et al. in preparation), the combined variance components of ESP-related factors were calculated (Sokal and Rohlf 1981) and displayed in Figure 4-5. The variation found among ESPs within each vegetation association was almost as great as variation among vegetation associations, a substantial amount considering the close proximity of ESPs within associations. 


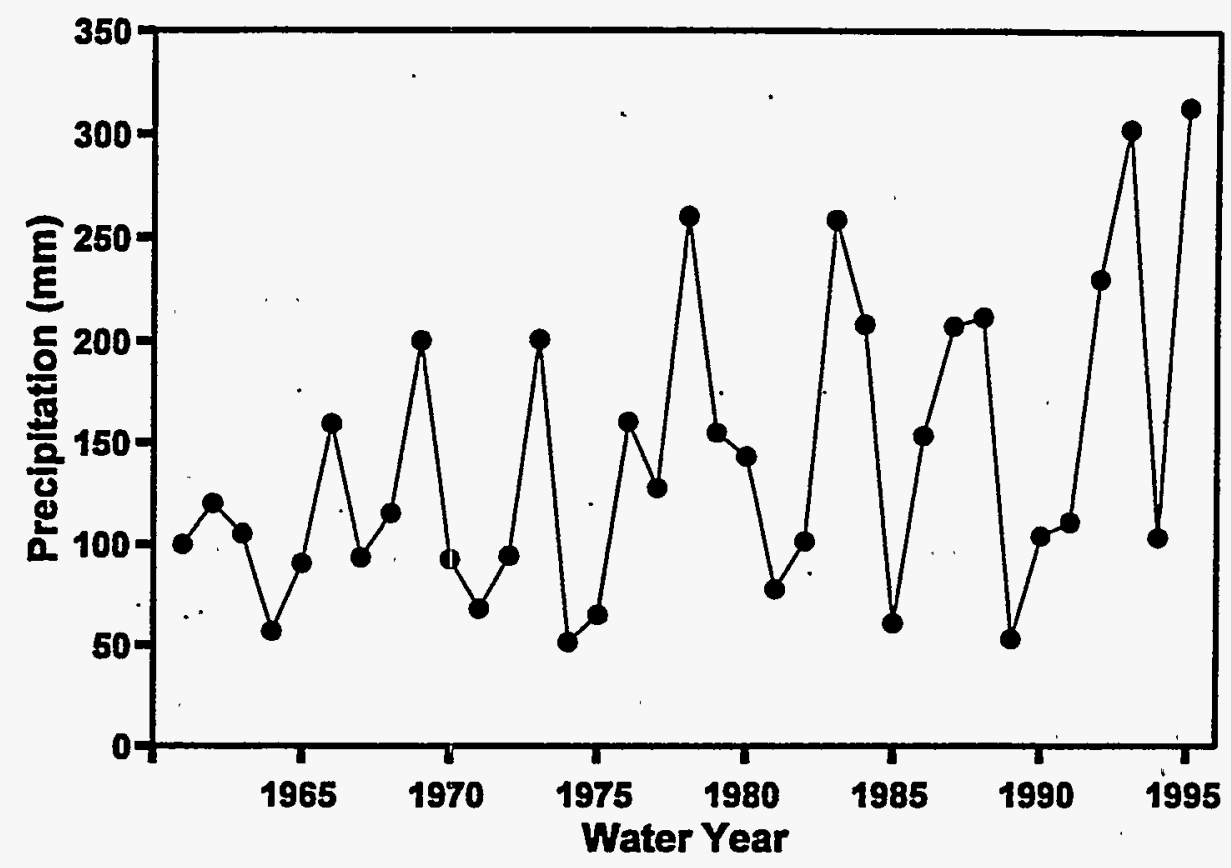

Figure 4-1. Total water year precipitation (mm) for a 35-year period at U.S. Geological Survey weather station 4JA, near Yucca Mountain, Nevada. The water year 1961, for example, extends from October 1, 1960, to September 30, 1961 (U.S. Department of Interior 1995).

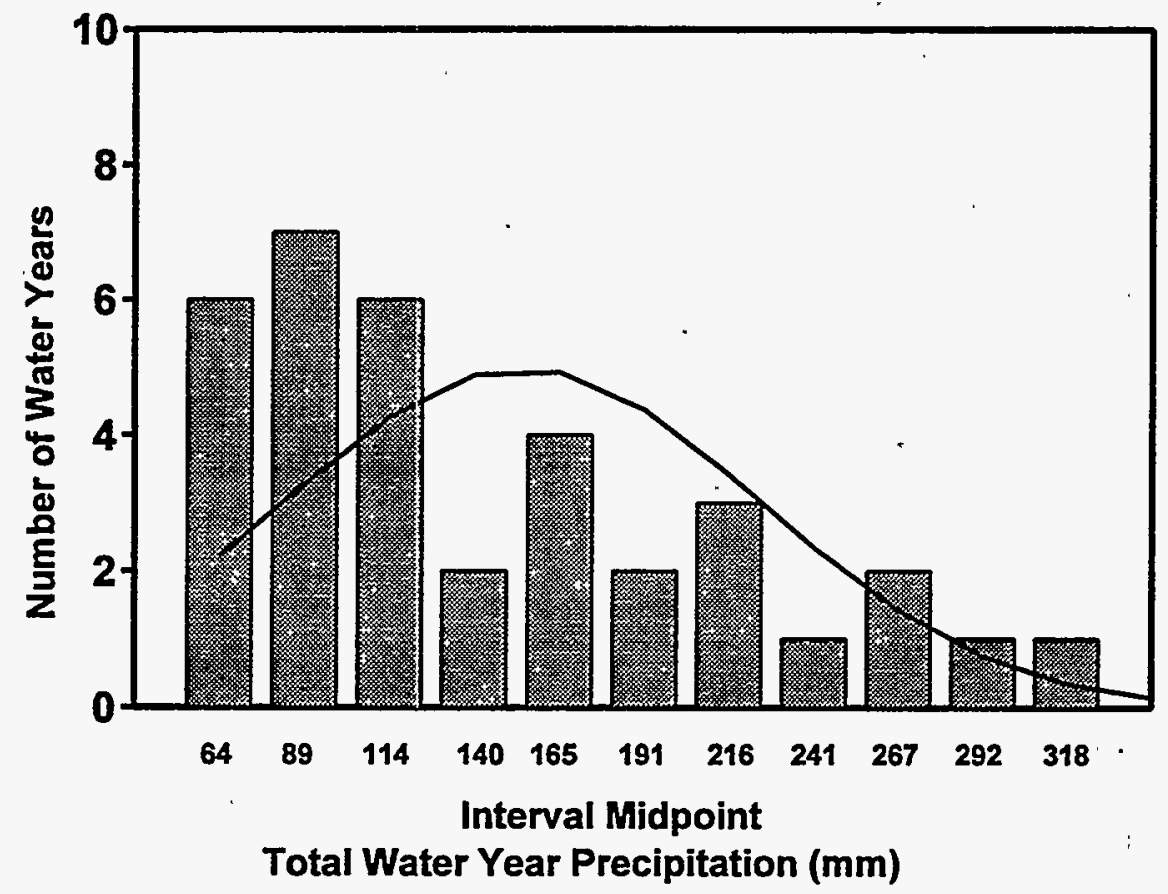

Figure 4-2. Comparison between the actual distribution of precipitation over 35 water years and a normal distribution with the same parameters $(\bar{x}=141.3 \mathrm{~mm}, \sigma=72.1$, and $n=$ $35)$. The distributions are significantly different $(P<0.001$, Kolomogorov-Smirnoff test). Precipitation data are from U.S. Geological Survey weather station 4JA near Yucca Mountain, Nevada. 


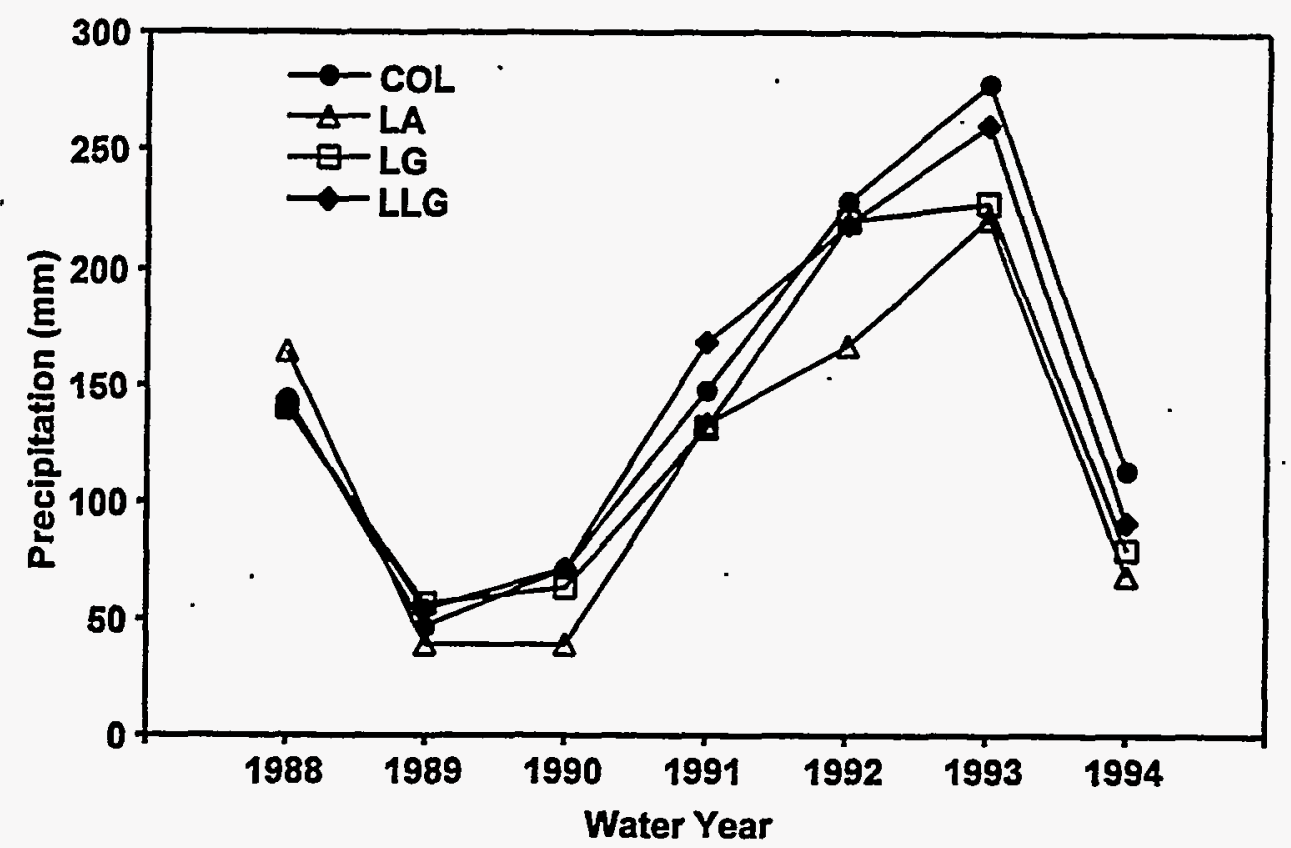

Figure 4-3. Water year precipitation (mm) for the Coleogyne (COL), Larrea-Ambrosia (LA), Lycium-Grayia (LG), and Larrea-Lycium-Grayia (LLG) vegetation associations from 1988 to 1994.

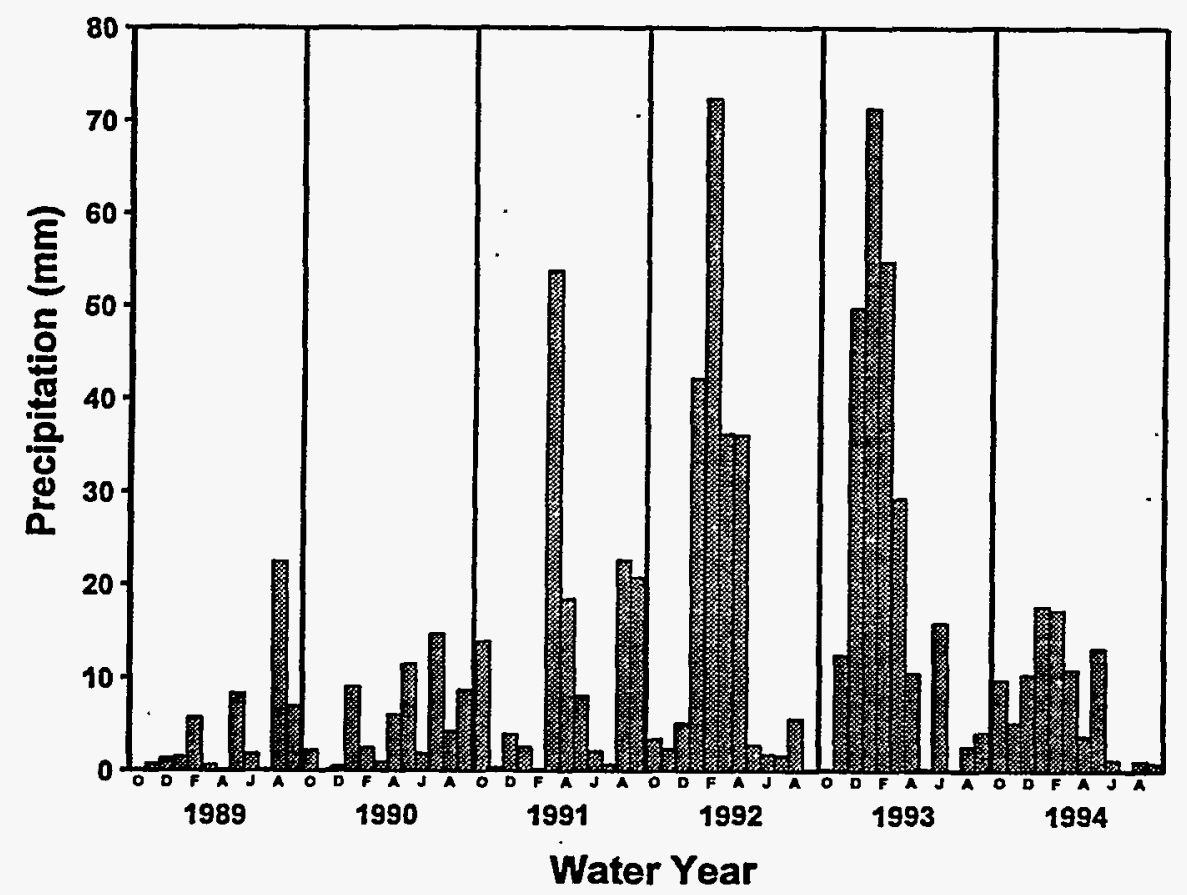

Figure 4-4. A six-year history of monthly precipitation (mm) for water years 1988 to 1994. Monthly precipitation values for 1988 and 1990 were averages from five U.S. Geological Survey collection sites at Yucca Mountain, Nevada. Precipitation values for 1991 through 1994 were averages of precipitation collected at the 48 Ecological Study Plots (ESPs) at Yucca Mountain. 
Table 4-1. Analysis of variance (ANOVA) of yearly precipitation on Ecological Study Plots (ESPs) at Yucca Mountain, Nevada. Monthly precipitation readings were measured from a total of 12 ESPs evenly distributed within four vegetation associations over four years (1991 to 1994).

\begin{tabular}{|c|c|c|c|c|}
\hline Source & df & MS & $F$ & $P<$ \\
\hline \multicolumn{5}{|c|}{ Among ESPs } \\
\hline $\begin{array}{c}\text { Vegetation } \\
\text { Association }\end{array}$ & 3 & 19,178 & 29.41 & 0.0001 \\
\hline ESP (Vegetation Association) & 44 & 652 & & \\
\hline \multicolumn{5}{|c|}{ Within ESPs } \\
\hline Year & 3 & 233,715 & 648.24 & 0.0001 \\
\hline Vegetation Association * Year & 9 & 2,271 & 9.86 & 0.0001 \\
\hline $\begin{array}{c}\text { Year * ESP (Vegetation } \\
\text { Association) }\end{array}$ & i41 & 361 & & \\
\hline
\end{tabular}

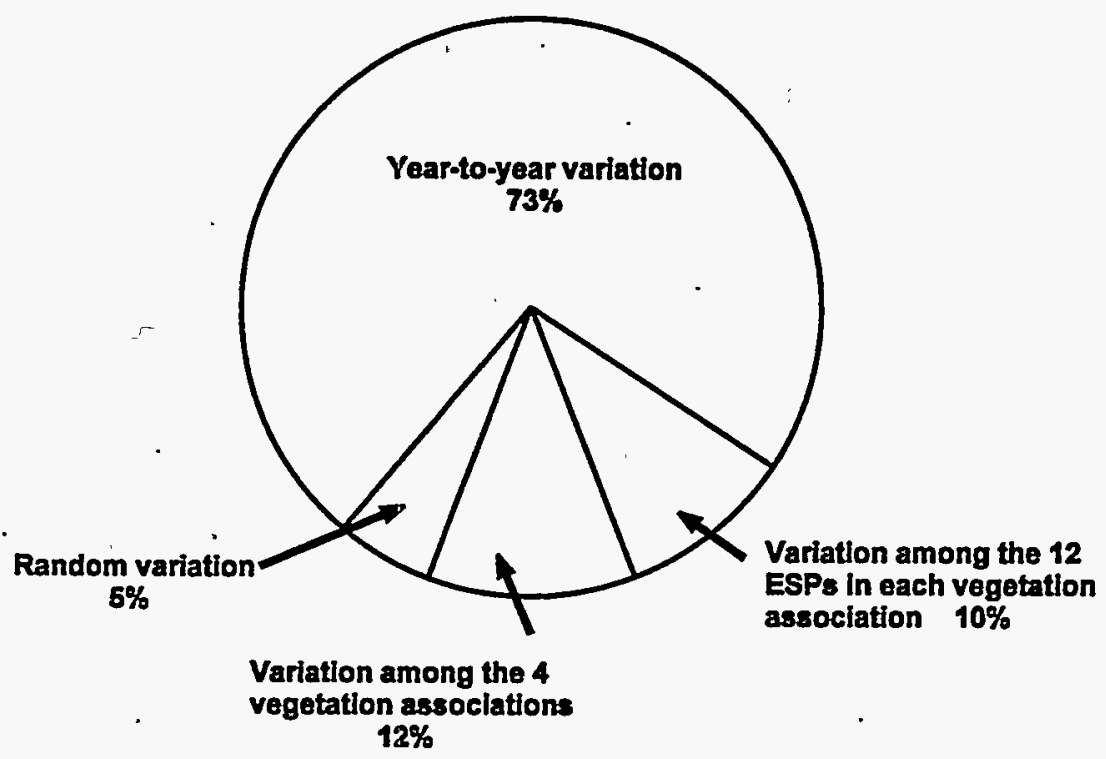

Figure 4-5. Components of variance from the analysis of variance (ANOVA) of yearly precipitation falling on individual Ecological Study Plots (ESPs) within four vegetation associations at Yucca Mountain, Nevada. The variance of each factor in the ANOVA is expressed as a percent of the total variation. 
Temperature. Temperatures at Yucca Mountain varied seasonally with hot summers and cold winters. From 1991 to 1994 extreme temperatures for all vegetation types ranged from $-20^{\circ} \mathrm{C}$ to $49^{\circ} \mathrm{C}$. July, August, and September were the hottest months, with extreme maximum temperatures never falling below $30^{\circ} \mathrm{C}$ at an ESP.

August had the highest maximum temperatures, ranging from $32^{\circ} \mathrm{C}$ to $49^{\circ} \mathrm{C}$. During December, January, and February, extreme minimum temperatures ranged from $9^{\circ} \mathrm{C}$ to $-20^{\circ} \mathrm{C}$ : After February, below freezing temperatures were recorded only in March 1991.

Beatley (1974a) argued that the distribution of Larrea (and possibly other Mojave Desert species) is limited by extreme low temperatures, rather than average low temperatures. The coldest temperature recorded in each vegetation association ranged from $-28^{\circ} \mathrm{C}$ to $-7^{\circ} \mathrm{C}$ (Figure 4-6). Extreme lows did not range more than five Celsius degrees between the four vegetation associations over the four years. Within vegetation associations, the four-year range in extreme lows was typically ten Celsius degrees. Despite its high elevation, LG had the warmest extreme low each year, and, despite its low elevation, LA often had the coldest low temperature. Extreme lows in the LA vegetation association are likely caused by cold air accumulation in basins (Rundel and Gibson 1996).

Soil Moisture. Monthly fluctuations, from 1991 to 1994, in soil moisture at ESP 6T in the LLG vegetation association are shown in Figure 4-7. Similar patterns were observed at other ESPs. Soil moisture decreased dramatically from February to May, and soil was consistently dry for the remainder of the summer. Soil moisture is recharged by winter and spring rains far more than by similar amounts of rain falling during the summer. Even for years with similar total rainfall (such as 1992 and 1993, or 1991 and 1994), the pattern of winter and spring recharge differs substantially. Recharge may begin as late as March (e.g., 1991) or as early as December (e.g., 1992).

The three soil depths $(15,30$, and $45 \mathrm{~cm})$ typically differ in moisture content. As expected, soil near the surface is either wetter or drier than soil at $45 \mathrm{~cm}$. For example, in August and September 1991, soil at $15 \mathrm{~cm}$ became moist after several summer rains, but this moisture did not reach $45 \mathrm{~cm}$. Conversely, during a dry period (July 1993), the top $15 \mathrm{~cm}$ became drier than soil at $45 \mathrm{~cm}$, which still held some residual spring moisture.

There can be up to a month delay before rainfall infiltrates the lower soil layers. An example of this delay is March to April 1991 (Figure 4-7), and again from January to March 1994. Soil moisture measurements verify the general assumption that, despite unmeasured loss from runoff, evaporation and percolation, precipitation is accumulating where it can be used by plants.

\subsection{PLANT COVER, DENSITY, AND PRODUCTION}

\subsubsection{Cover}

Vegetative ground cover at Yucca Mountain fluctuates from year to year. In 1991, the last year of a three-year drought, the average cover across all 48 ESPs dropped to 15 percent, and then increased to the six-year maximum of 28 percent the following year (Figure 4-8). Even during the most favorable years for growth, almost 60 percent of the ground cover was soil and rock (Figure 4-8). 


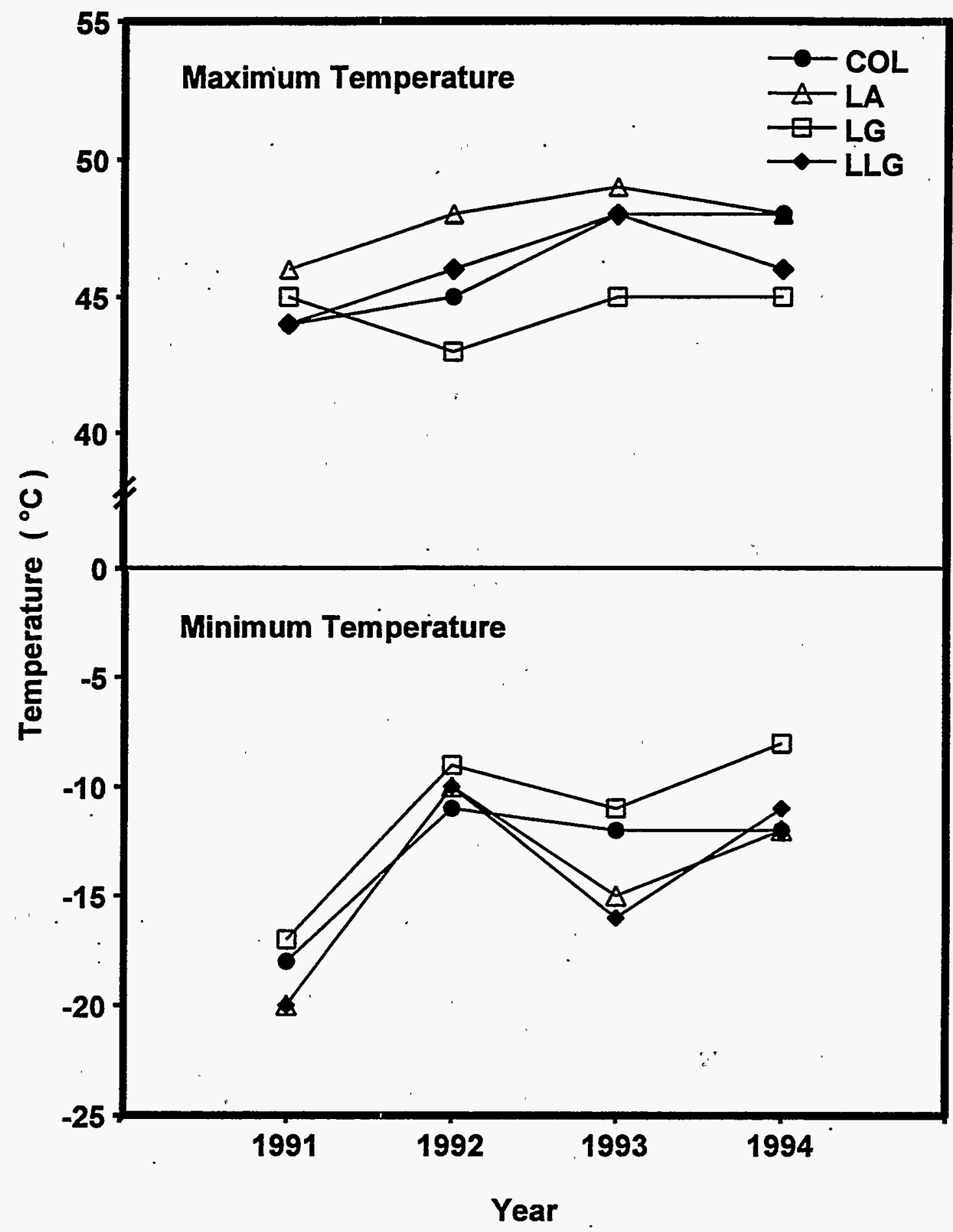

Figure 4-6. Extreme maximum and minimum temperatures among the 12 Ecological Study Plots (ESPs) in the Coleogyne (COL), Larrea-Ambrosia (LA), Lycium-Grayia (LG) and the Larrea-Lycium-Grayia (LLG) vegetation associations from 1991 to 1994 at Yucca Mountain, Nevada. 


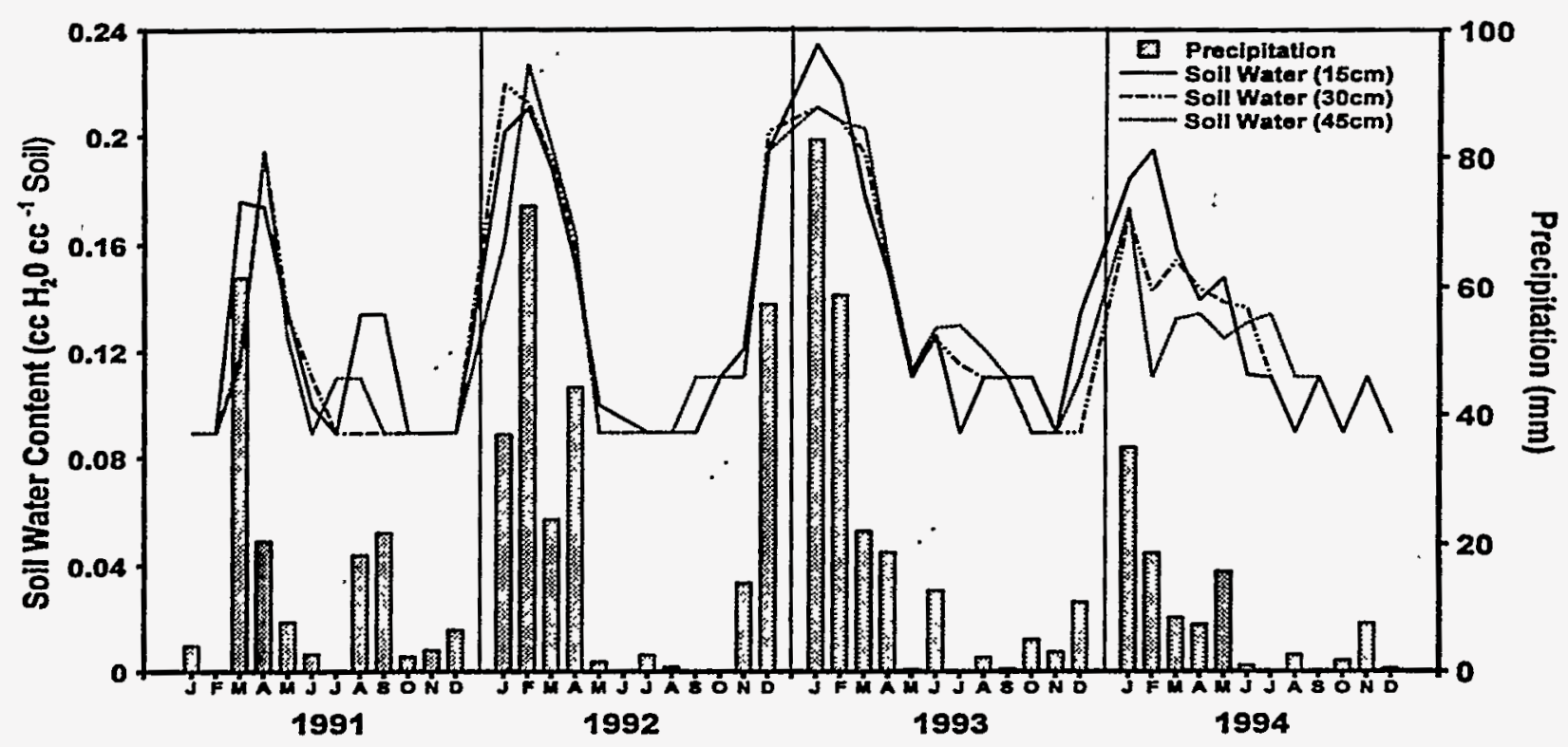

Figure 4-7. Soil water content (cc $\mathrm{H}_{2} \mathrm{O} \mathrm{cc}{ }^{-1}$ soil) and precipitation $(\mathrm{mm})$ at a representative Ecological Study Plot (ESP) during 1991 through 1994. Soil water content was measured at three depths $(15,30$, and $45 \mathrm{~cm})$ on ESP $6 \mathrm{~T}$ in the LLG vegetation association at Yucca Mountain, Nevada. If more than one reading was taken within a month (March through May), measurements were averaged for that period.

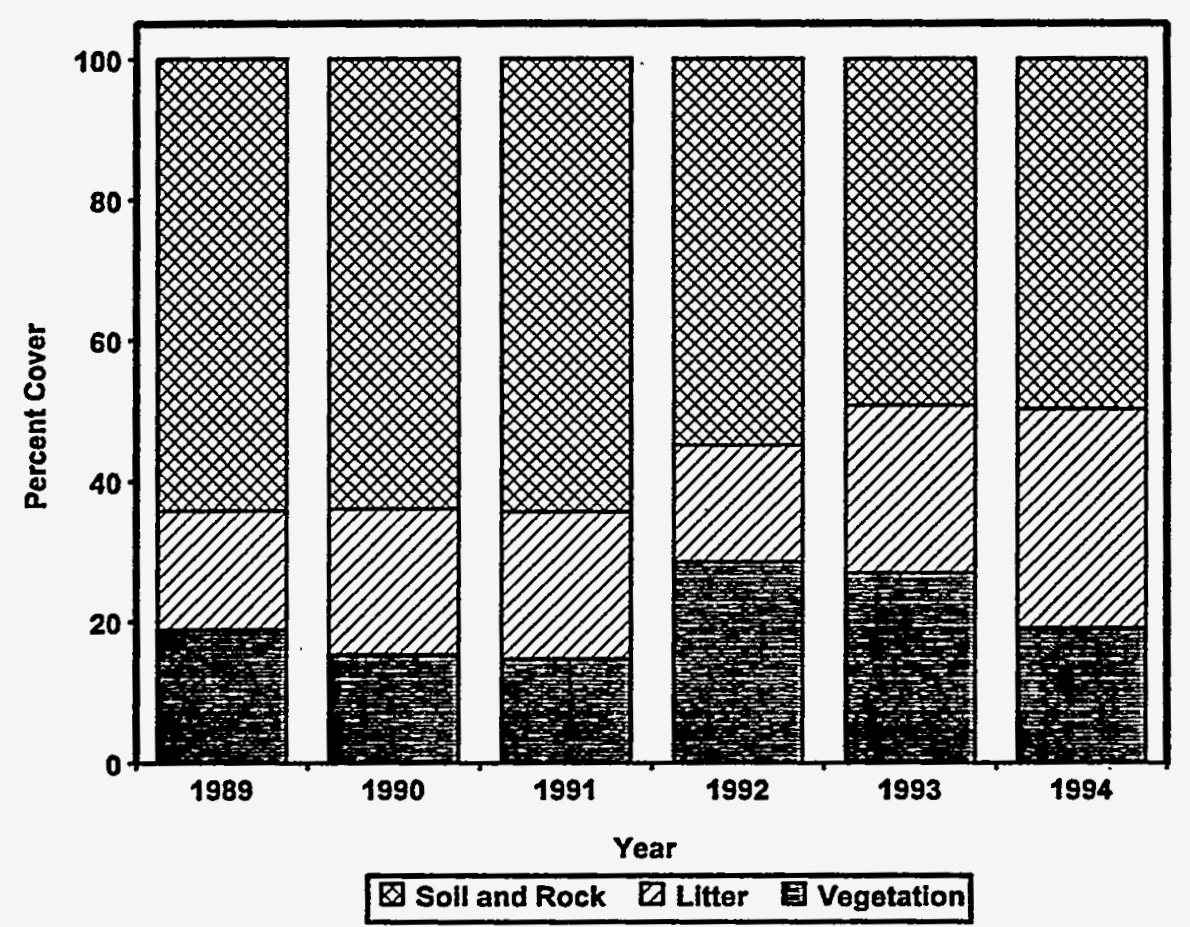

Figure 4-8. Average percent cover of vegetation, litter, soil and rock on 48 Ecological Study Plots (ESPs) from 1989 to 1994 at Yucca Mountain, Nevada. 
Throughout the six-year study period, the cover of litter (unrooted, dead vegetation) was roughly the same as vegetative cover (Figure 4-8). During the drought years, a continual mortality and excision of leaves and twigs from shrubs was observed. This steady litter fall decreased vegetative cover and increased litter cover during the drought. Because decomposition is known to be positively correlated with both short- and long-term precipitation (Strojan et al. 1987; Santos et al. 1984), decreasing decomposition rates during the drought probably contributed to increasing litter cover.

Most of the fluctuation in cover was the result of variation in rainfall. Total vegetative cover was significantly and positively correlated with precipitation in each of five calendar intervals (Table 4-2). The sum of precipitation from December through April (SPR_WIN) was the best single predictor of cover.

Approximately 58 percent of the variability in plant cover was explained by a combination of five variables: (SPR_WIN) ${ }^{2}$, PREV_YR, (GROW_YR) ${ }^{2}$, FALL_WIN, and (WATER_YR) ${ }^{2}$ (Table 4-3). This model was selected using stepwise linear regression, and represents the best compromise between maximizing the correlation between cover and precipitation and minimizing the number of variables in the equation.

The amount of precipitation in each calendar interval contributes significantly to the full model. However, a variable's slope may be negative, even though its correlation coefficient was positive. This indicates that (GROW_YR) ${ }^{2}$ and FALL_WIN have a slightly negative effect on cover after (SPR_WIN) ${ }^{2}$ and PREV_YR have been taken into consideration. Other reasonable models were inspected using Mallow's $C_{p}$ method (Weisberg 1980). All of the best 30 models (meeting the $P<0.05$ significance criteria for each variable) included the same calendar intervals, differing only in whether the original or the squared form of each independent variable was used.

Annuals. Winter annual cover fluctuated greatly during the study (Figure 4-9), indicating their reliance on the unpredictable Mojave Desert climate (Beatley 1969a). For example, in 1989 no annuals were censused during cover measurements, and less than 1 percent of the vegetative cover in 1990 was contributed by annual plants. However, in 1992 and 1993 annuals covered more ground surface than shrubs.

Annual plant cover was highly correlated with SPR_WIN, GROW_YR, and WATER_YR (Table 4-2). Each of these variables explained between 67 and 70 percent of the growth of annuals (Table 4-2). Only 23 percent and 11 percent of this growth is explained by FALL_WIN and PREV_YR, respectively. The significant influence of PREV_YR was unexpected for annuals, and could reflect previous seed production, an artifact of the study window, or other factors discussed in Subsection 5.1.

Four calendar intervals form the most successful model of desert annual plant vegetative cover changes over time. Of the five variables in Table 4-2, only GROW_YR was excluded. In this model, SPR_WIN explains 70 percent of the variability in annual plant cover. The amount of FALL_WIN precipitation decreases plant growth, once the effect of SPR_WIN precipitation is taken into account. 
Table 4-2. Correlation ( $r$ ) between plant growth, measured as percent cover or primary productivity, and the total precipitation in five calendar intervals at Yucca Mountain, Nevada. Plants were measured in either 6 (cover) or 4 (production) years at 48 Ecological Study Plots (ESPs). Several additions and deletions to this schedule are described in Subsection 3.6. All correlations are statistically significant at $P<0.001$, except $*$, which is significant at $P=0.011$. Variable names are calendar intervals described in Table 4-1.

All Plants (Shrubs, Annuals, Perennial Forbs and Grasses)

\begin{tabular}{|c|c|c|c|c|c|c|}
\hline $\begin{array}{c}\text { Variable } \\
\text { Name }\end{array}$ & N & SPR_WIN & FALL_WIN & GROW_YR & WATER_YR & PREV_YR \\
\hline \% Cover & 271 & 0.666 & 0.379 & 0.651 & 0.611 & 0.458 \\
\hline $\begin{array}{c}\text { Primary } \\
\text { Production }\end{array}$ & 188 & 0.890 & 0.629 & 0.897 & 0.888 & 0.526 \\
\hline
\end{tabular}

Annuals

\begin{tabular}{|c|c|c|c|c|c|c|}
\hline $\begin{array}{c}\text { Variable } \\
\text { Name }\end{array}$ & $\mathbf{N}$ & SPR_WIN & FALL_WIN & GROW_YR & WATER_YR & PREV_YR \\
\hline$\%$ Cover & 271 & 0.836 & 0.477 & 0.830 & 0.821 & 0.334 \\
\hline $\begin{array}{c}\text { Primary } \\
\text { Production }\end{array}$ & 212 & 0.750 & 0.483 & 0.750 & 0.756 & 0.327 \\
\hline
\end{tabular}

Shrubs

\begin{tabular}{|c|c|c|c|c|c|c|}
\hline $\begin{array}{c}\text { Variable } \\
\text { Name }\end{array}$ & N & SPR_WIN & FALL_WIN & GROW_YR & WATER_YR & PREV_YR \\
\hline$\%$ Cover & 271 & -0.438 & -0.229 & -0.450 & -0.501 & $0.115^{*}$ \\
\hline $\begin{array}{c}\text { Primary } \\
\text { Production }\end{array}$ & 212 & 0.798 & 0.520 & 0.807 & 0.787 & 0.379 \\
\hline
\end{tabular}


Table 4-3. Regression models selected by the stepwise procedure. The model was the best combination of 10 measures of precipitation ( 5 calendar intervals by 2 power functions) to predict percent cover and primary productivity on ecological study plots at Yucca Mountain, Nevada. Each independent variable contributes significantly to the full model $(P<0.05)$, despite the presence or order of other independent variables in the model. Sample size is identical to Table 4-2. Calendar interval codes are described in Table 4-1.

All Plants (Shrubs, Annuals, Perennial Forbs and Grasses)

\begin{tabular}{|c|c|c|c|c|c|c|c|}
\hline \multicolumn{4}{|c|}{ \% Cover } & \multicolumn{3}{c|}{ Primary Productivity } \\
\hline $\begin{array}{c}\text { Independent } \\
\text { Variable }\end{array}$ & Slope & Model $r^{2}$ & $P<$ & $\begin{array}{c}\text { Independent } \\
\text { Variable }\end{array}$ & Slope & Model $r^{2}$ & $P<$ \\
\hline Intercept & 12.27 & & & Intercept & -0.159 & & \\
\hline (SPR_WIN) $^{2}$ & 0.001 & 0.470 & 0.001 & GROW_YR & 0.465 & 0.804 & 0.001 \\
\hline PREV_YR & 0.039 & 0.517 & 0.001 & (GROW_YR) $^{2}$ & -0.001 & 0.809 & 0.001 \\
\hline (GROW_YR) $^{2}$ & -0.001 & 0.567 & 0.001 & (PREV_YR) $^{2}$ & 0.001 & 0.829 & 0.001 \\
\hline FALL_WIN & -0.076 & 0.576 & 0.020 & PREV_YR & -0.224 & 0.841 & 0.001 \\
\hline (WATER_YR $^{2}$ & $<0.000$ & 0.582 & 0.039 & & & &
\end{tabular}

Annuals

\begin{tabular}{|c|c|c|c|c|c|c|c|}
\hline \multicolumn{4}{|c|}{$\%$ Cover } & \multicolumn{4}{|c|}{ Primary Productivity } \\
\hline $\begin{array}{c}\text { Independent } \\
\text { Variable }\end{array}$ & Slope & Model $r^{2}$ & $P<$ & $\begin{array}{c}\text { Independent } \\
\text { Variable }\end{array}$ & Slope & Model $r^{2}$ & $P<$ \\
\hline Intercept & -0.045 & & & Intercept & -0.886 & & \\
\hline SPR_WIN & 0.0004 & 0.699 & 0.001 & (WATER_YR) $^{2}$ & 0.0004 & 0.576 & 0.001 \\
\hline FALL_WIN & -0.002 & 0.713 & 0.001 & \multirow{3}{*}{\multicolumn{4}{|c|}{$\therefore$}} \\
\hline$\left(P R E V_{-} Y R\right)^{2}$ & $<0.0000$ & 0.718 & 0.039 & & & & \\
\hline WATER_YR & 0.0006 & 0.728 & 0.002 & & & & \\
\hline
\end{tabular}

Shrubs

\begin{tabular}{|c|c|c|c|c|c|c|c|}
\hline \multicolumn{3}{|c|}{ \% Cover } & \multicolumn{3}{c|}{ Primary Productivity } \\
\hline $\begin{array}{c}\text { Independent } \\
\text { Variable }\end{array}$ & Slope & Model $r^{2}$ &,$P<$ & $\begin{array}{c}\text { Independent } \\
\text { Variable }\end{array}$ & Slope & Model $r^{2}$ & $P<$ \\
\hline Intercept & 0.166 & & & Intercept & -2.2612 & & \\
\hline WATER_YR & -0.0003 & 0.251 & 0.000 & GROW_YR & 0.6540 & 0.651 & 0.001 \\
\hline (GROW_YR) & $<0.0000$ & 0.371 & 0.000 & (GROW_YR) $^{2}$ & -0.0029 & 0.688 & 0.001 \\
\hline PREV_YR & 0.0002 & 0.408 & 0.000 & (WATER_YR) $^{2}$ & -0.0005 & 0.698 & 0.015 \\
\hline GROW_YR & -0.002 & 0.431 & 0.002 & FALL_WIN & 0.2196 & 0.713 & 0.003 \\
\hline SPR_WIN & 0.001 & 0.449 & 0.004 & (SPR_WIN) $^{2}$ & 0.0028 & 0.718 & 0.050 \\
\hline
\end{tabular}




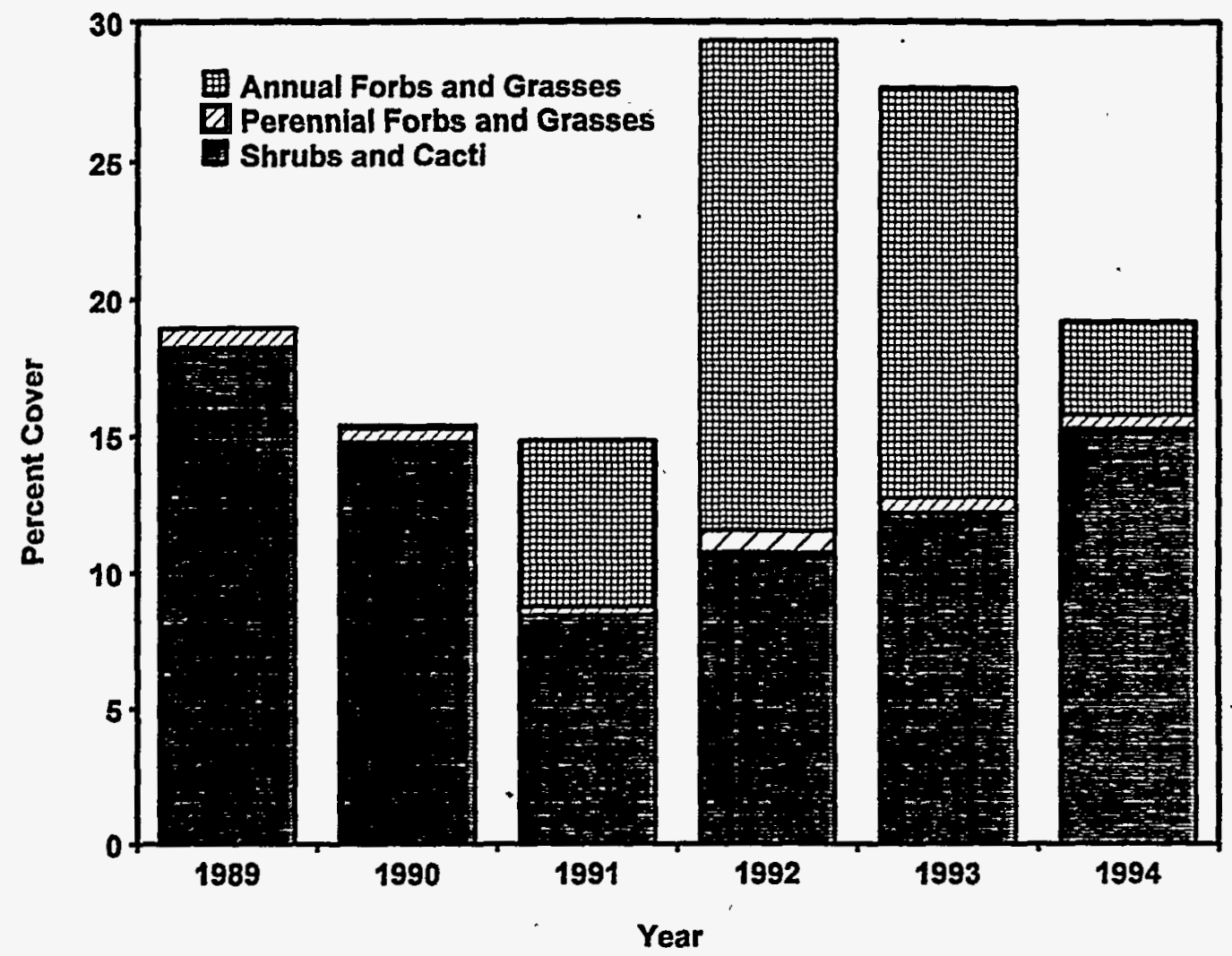

Figure 4-9 Yearly variation in percent cover among life forms (shrubs and cacti, perennial forbs and grasses, annual forbs and grasses) from 1989 to 1994 on 48 Ecological Study Plots (ESPS) at Yucca Mountain, Nevada.

Shrubs. The cover of shrubs also fluctuated yearly, although not as greatly as annuals. Between 1989 and 1991, shrub cover decreased 53 percent, from 19 to 9 percent (Figure 4-9). This is a time when few annuals were present; therefore, the decrease cannot be attributed to tall annuals covering low shrubs. However, after 1991 shrub cover increased annually, and in 1994 shrub cover was comparable to that measured in 1989.

Precipitation had a negative effect on the cover of shrubs (Table 4-2). This paradoxical result can be explained by the fact that percent cover is strictly a measurement of the ground surface area covered by plants, not the amount of new growth. Annuals, which are more responsive to precipitation than woody plants, tend to cover shrubs during favorable years. In fact, one guild of desert annuals preferentially germinates under shrubs and grows upward through their canopies (Went 1942; Rundel and Gibson 1996). Therefore, the negative shrub correlations in Table 4-3 may reflect changes in the abundance of life forms and not shrub growth. Stepwise regression analysis with precipitation calendar intervals as independent variables produced a model that explained 45 percent of the variability in shrub cover (Table 4-3). However, no single variable in the model explained more than 25 percent of the variability. 
Perennial Forbs and Grasses. The contribution of perennial forbs and grasses to total vegetative cover was small, generally between 0.5 and 2 percent across years. Because of this small amount of variability, the effect of precipitation on this life form's cover was not analyzed.

Vegetation Associations. Vegetation associations did not respond similarly each year (Figure 4-10), partially the result of differences in rainfall among associations and differences in the physiognomy among associations. For example, the LLG association had the least amount of cover in 1990, a drought year, and the greatest amount of cover in 1992 and 1993, the wettest years. The cover of each ESP within each association is listed in Appendix Bl.

Species composition, especially the relative abundance of the three major life forms, accounted for much of the difference between vegetation associations. Shrub cover (Figure 4-10) was consistent among years and vegetation associations, never differing by more than five percent. Much of the difference between vegetation associations was attributable to differences in the growth response of winter annuals. In several years, annual cover varied from 10 to 20 percent among vegetation associations. The LLG association consistently had the highest annual cover followed by the COL and LG associations. The LA association always had the least annual cover.

\subsubsection{Density}

As with vegetative cover, the density of perennial plant species within vegetation associations was variable across the Yucca Mountain landscape. The LLG association, dominated by large Larrea tridentata with spreading, diffuse canopies averaged only 62 individuals $100 \mathrm{~m}^{-2}$; while the LG association, dominated by smaller less woody shrubs typical of the Great Basin Desert (Shreve 1942) averaged 139 individuals $100 \mathrm{~m}^{-2}$ (Figure 4-11). In the COL vegetation association, Coleogyne ramosissima and Ambrosia dumosa had the highest densities, 18.6 and 17.3 individuals $100 \mathrm{~m}^{-2}$, respectively (Appendix C1). In the LG association Ephedra nevadensis, Sphaeralcea ambigua, Stipa speciosa, and Erioneuron pulchellum were the most abundant with densities ranging from 12 to 14 individuals $100 \mathrm{~m}^{-2}$ (Appendix $\mathrm{C1}$ ). The most abundant species in the LLG association were Ambrosia dumosa (12.9 individuals $100 \mathrm{~m}^{-2}$ ) and Krameria erecta (11.7 individuals $100 \mathrm{~m}^{-2}$ ) (Appendix C1). In the LA association, Ambrosia dumosa was by far the most abundant species, with 61.5 individuals $100 \mathrm{~m}^{-2}$.

Adult Mortality and Juvenile Recruitment. Mortality and recruitment measurements provide an estimate of yearly population dynamics within the LLG vegetation association. Adult plant mortality (regardless of species) was almost six times greater between 1992 and 1993 than it was in the previous year (1991 to 1992) (Figure 4-12). Juvenile recruitment from 1992 to 1993 was slightly less than the previous year. Juvenile recruitment exceeded mortality in 1992, but their relative magnitude reversed in 1993, when mortality was greater than juvenile recruitment. 


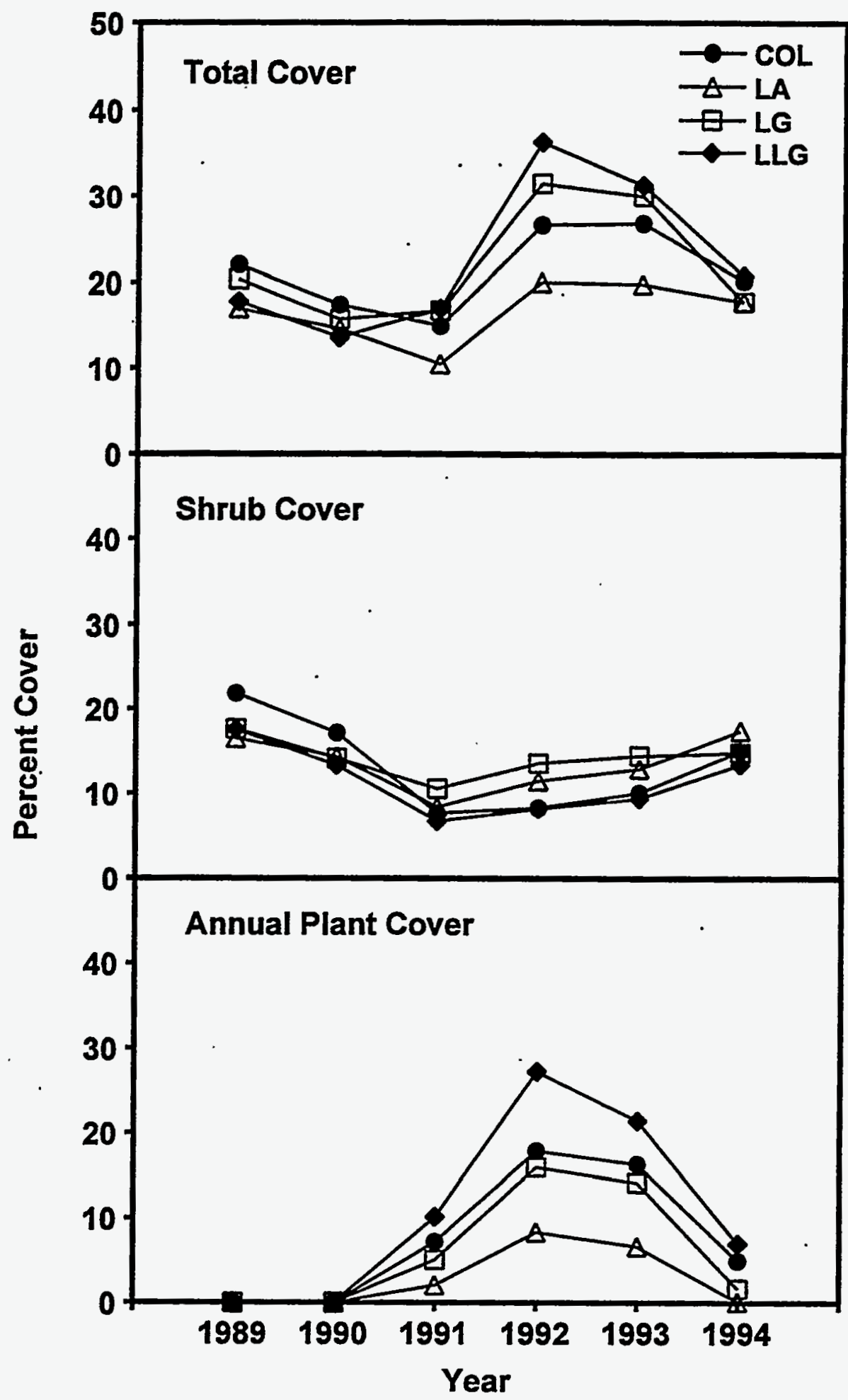

Figure 4-10. Comparison of total cover, shrub cover, and annual plant cover (\%) from 1989 to 1994 in the Coleogyne (COL), Larrea-Ambrosia (LA), Lycium-Grayia (LG) and the Larrea-Lycium-Grayia (LLG) vegetation associations at Yucca Mountain, Nevada. 


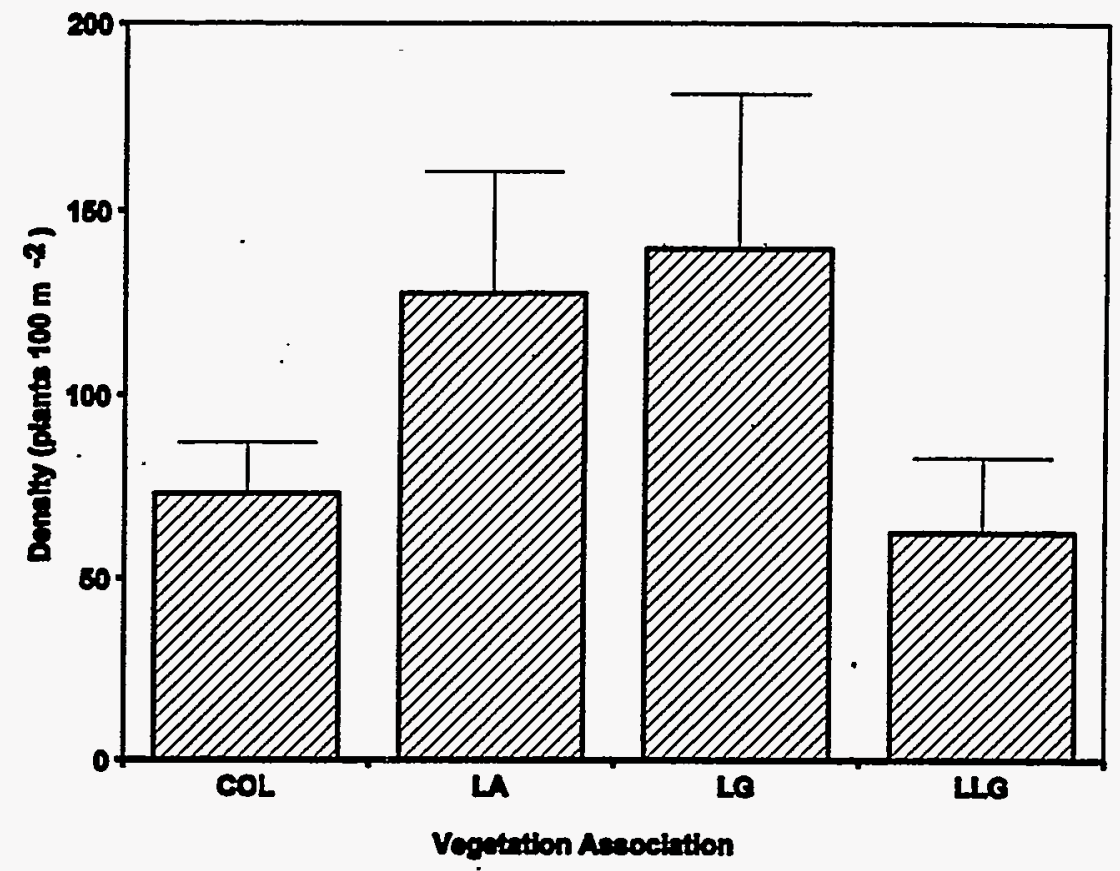

Figure 4-11. Average density (plants $100 \mathrm{~m}^{-2} \pm$ standard deviation) of all perennial plants in 12 Ecological Study Plots (ESPs) for the Coleogyne (COL), Larrea-Ambrosia (LA), Lycium-Grayia (LG) and the Larrea-Lycium-Grayia (LLG) vegetation associations at Yucca Mountain, Nevada.

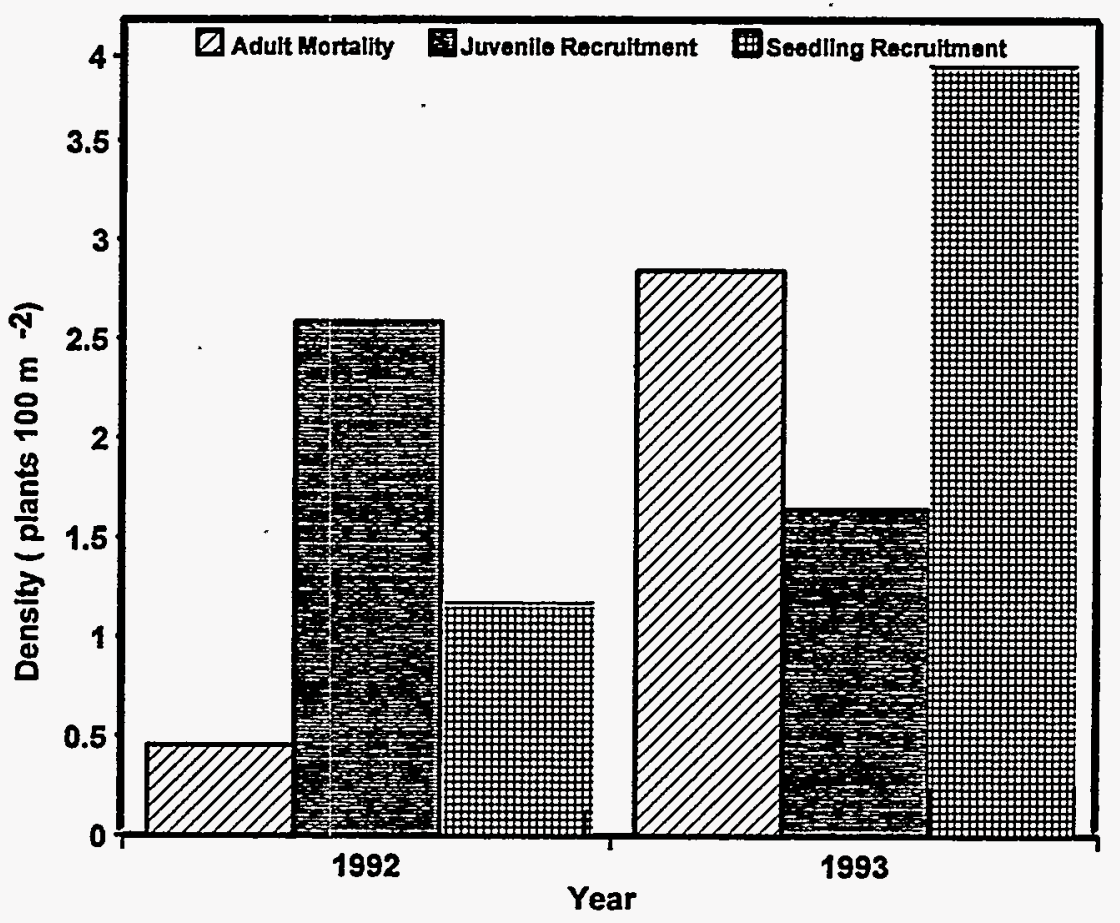

Figure 4-12. Adult mortality (death of plants $>1$ yr old), juvenile recruitment (plants $>1$ yr old not seen in previous years), and seedling recruitment (plants $<1$ yr old) of perennial plants in the Larrea-Lycium-Grayia (LLG) vegetation association for 1992 and 1993. Three functionally annual species were excluded from this analysis. 
Forbs and grasses were the most dynamic perennials species in the LLG community, with high mortality and recruitment (Table 4-4). Several of these species, such as Stephanomeria pauciflora and Sphaeralcea ambigua, are short-lived colonizers common in disturbed vegetation (Carpenter et al. 1986; Vasek and Barbour 1977). A separate group of perennial forbs and grasses, such as Erioneuron pulchellum, Stephanomeria pauciflora, and Mirabilis bigelovii appeared to be functionally annual. Although these species are capable of perennial growth under favorable conditions, the same individuals were not always observed consistently during the three years of measurement. Astragalus layneae, Eriogonum inflatum, and Euphorbia albomarginata, all described as perennials in Hickman (1993), functioned exclusively as annuals, since no single individual of these three species was censused for two consecutive years. For this reason, these three species were omitted from the analysis .

Larrea tridentata, Lycium pallidum, and Ephedra nevadensis, three of the dominant species in the LLG vegetation association, were static during 1991 to 1993, with very low mortality and recruitment (Table 4-4). Static species tend to be long-lived components of climax or late successional vegetation (Carpenter et al. 1986; Webb et al. 1987). Most species in the LLG vegetation were not clearly static or dynamic. Hymenoclea salsola has been listed by Vasek and Barbour (1977) and Carpenter et al. (1986) as being a short-lived colonizer capable of high recruitment, but was reasonably static during these two years. Carpenter et al. (1986) found Acamptopappus, Lycium, and Ericameria in disturbed as well as undisturbed vegetation. These genera are moderately dynamic at Yucca Mountain; that is, both mortality and recruitment occurred. However, the shrubs Lycium andersonii, Encelia virginensis, Grayia spinosa, and Krascheninninkovia lanata had a high mortality, but lacked a corresponding high recruitment.

Seedling Recruitment. Although seedlings were censused during two consecutive wet years, the number of seedlings was low. Seedling recruitment was $1.05100 \mathrm{~m}^{-2}$ in 1992 and increased almost 400 percent in 1993, to $3.94100 \mathrm{~m}^{-2}$. The increase in 1993 is probably the result of seed production during the spring of 1992, and the consequent recharge of the seed bank. Ackerman (1979) made a careful census of Mojave Desert seedlings in nearby Rock Valley and reported average yearly survival of 3.8 seedlings $100 \mathrm{~m}^{-2}$, a recruitment rate similar to 1993 . However, Ackerman's yearly recruitment reached 13.9 seedlings $100 \mathrm{~m}^{-2}$ during a favorable year, considerably greater than at Yucca Mountain during 1993, another favorable year. Ackerman censused seedlings at biweekly intervals throughout the year; whereas recruitment in this study was based on a single, yearly census. According to Ackerman, our early to mid summer census would have missed major germination events, because Larrea and Ambrosia usually germinate after late summer rains. Ackerman also recorded the initial germination and subsequent death of many more individuals than counted in our censuses.

\subsubsection{Production}

Productivity was variable among years (Table 4-5). Production was lowest in $1989\left(0.72 \mathrm{~kg} \mathrm{ha}^{-1}\right)$, but increased each year after that, reaching peak levels in $1992\left(479 \mathrm{~kg} \mathrm{ha}^{-1}\right)$ and $1993\left(661 \mathrm{~kg} \mathrm{ha}^{-1}\right.$; LLG only). Production was comparable to other measurements from the Mojave Desert (Bamberg et al. 1976; Beatley 1969a; Rundel and Gibson 1996; Turner and Randall 1989; Wallace and Romney 1972; Webb et al. 1978). 
Table 4-4. Mortality and recruitment of perennial species in the Larrea-Lycium-Grayia vegetation association at Yucca Mountain, Nevada. Mortality and recruitment are expressed as percent change from the previous year, and density, averaged over the three-year census period $1991-1993$, is expressed as the number of plants $100 \mathrm{~m}^{-2}$ ("T" indicates density $<0.1$ ).

\begin{tabular}{|c|c|c|c|c|c|}
\hline \multirow[b]{2}{*}{ Species } & \multirow[b]{2}{*}{ Density } & \multicolumn{2}{|c|}{ Mortality (\%) } & \multicolumn{2}{|c|}{ Recruitment (\%) } \\
\hline & & 1992 & 1993 & 1992 & 1993 \\
\hline Acamplopappus shockleyi & 0.27 & 0 & 3.33 & 0 & 0 \\
\hline Ambrosia dumosa & 12.57 & 1.15 & 3.35 & 1.46 & 0.46 \\
\hline Aristida purpurea & $\mathrm{T}$ & 0 & 0 & 14.29 & 0 \\
\hline Atriplex canescens & $\mathrm{T}$ & 0 & 0 & 0 & 14.29 \\
\hline Atriplex confertifolia & 0.22 & 0 & 4.00 & 30.00 & 16.00 \\
\hline Coleogyne ramosissima & 0.50 & 0 & 0 & 0 & 1.85 \\
\hline Echinocereus engelmannii & $\mathrm{T}$. & 0 & 0 & 0 & 25.00 \\
\hline Echinocactus polycephalus & $\mathrm{T}$ & 0 & 0 & $\mathbf{0}$ & 0 \\
\hline Encelia virginensis & 0.93 & 1.06 & 15.24 & 12.77 & 0 \\
\hline Ephedra nevadensis & 9.10 & 0.22 & 2.36 & 0.86 & 0.86 \\
\hline Ephedra viridis & $\mathrm{T}$ & $\mathbf{0}$ & 0 & 0 & 0 \\
\hline Ericameria cooperi & 2.25 & 0 & 6.00 & 5.15 & 0.80 \\
\hline Eiriogonum fasciculatum & 0.77 & 1.22 & 7.06 & 4.88 & 2.35 \\
\hline Erioneuron pulchellum & 2.45 & 1.34 & 3.97 & 85.91 & 38.99 \\
\hline Grayia spinosa & 0.64 & 0 & 11.43 & 2.94 & 1.43 \\
\hline Gutierrezia sarothrae & $\mathrm{T}$ & 0 & 0 & 0 & 0 \\
\hline Hymenoclea salsola & 2.86 & 0.64 & 1.94 & 1.60 & 0.32 \\
\hline Krameria erecta & 11.13 & 0.53 & 2.45 & 1.85 & 0.87 \\
\hline Krascheninnikovia lanata & 1.10 & 2.48 & 7.63 & 0 & 0 \\
\hline Larrea Iridentata & 5.71 & 0 & 0.83 & 0.83 & 1.32 \\
\hline Lepidizm fremontii & $\mathrm{T}$ & 0 & 0 & 0 & 0 \\
\hline Lycium andersonii & 3.90 & 0.23 & 22.94 & 1.39 & 0 \\
\hline I.vcium pallidum & 0.94 & 0.99 & 0.99 & 0.99 & 0.99 \\
\hline Menodora spinescens & 2.60 & 1.12 & 2.11 & 7.84 & 2.46 \\
\hline Mirabilis bigelovii & 0.18 & 0 & 11.70 & 0 & 5.88 \\
\hline Opuntia basilaris & $\mathrm{T}$ & 0 & 0 & 12.50 & 0 \\
\hline Opuntia echinocarpa & $\mathrm{T}$ & 0 & 0 & 0 & 0 \\
\hline
\end{tabular}


Table 4-4 (continued)

\begin{tabular}{|l|c|c|c|c|c|}
\hline \multirow{2}{*}{ Species } & \multirow{2}{*}{ Density } & \multicolumn{2}{c|}{ Mortality (\%) } & \multicolumn{2}{c|}{ Recruitment (\%) } \\
\cline { 3 - 6 } & & 1992 & 1993 & 1992 & 1993 \\
\hline Oryzopsis hymenoides & 0.14 & 7.14 & 12.50 & 21.43 & 6.25 \\
\hline Psorothamnus fremontii & $\mathrm{T}$ & 0 & 0 & 0 & 0 \\
\hline Salazaria mexicana & 1.26 & 0 & 0.77 & 2.34 & 0 \\
\hline Sphaeralcea ambigua & 0.25 & 0 & 13.33 & 45.00 & 10.00 \\
\hline Stephanomeria pauciflora & 0.31 & 3.45 & 8.82 & 31.03 & 17.65 \\
\hline Stipa speciosa & 1.04 & 9.01 & 14.55 & 1.80 & 2.73 \\
\hline Tetradymia axillaris & $\mathrm{T}$ & 0 & 0 & 0 & 0 \\
\hline Xylorhiza tortifolia & $\mathrm{T}$ & 0 & 0 & 50.00 & 0 \\
\hline
\end{tabular}

*Short-lived perennial herbs and grasses were omitted (Astragalus layneae, Eriogonum inflatum, and Euphorbia albomarginata).

Table 4-5. Net annual aboveground primary production $\left(\mathrm{g} \mathrm{m}^{-2}\right)$ in the Coleogyne (COL), LarreaAmbrosia : (LA), Lycium-Grayia (LG), Larrea-Lycium-Grayia (LLG) vegetation associations at Yucca Mountain, Nevada.

\begin{tabular}{|c|c|c|c|c|}
\hline \multirow[b]{2}{*}{$\begin{array}{c}\text { Vegetation } \\
\text { Association } \\
\end{array}$} & & \multicolumn{3}{|c|}{ Net Annual Aboveground Primary Production ( $\mathrm{g} \mathrm{m}^{-2}$ ) } \\
\hline & Shrubs & $\begin{array}{c}\text { Perennial } \\
\text { Forbs and } \\
\text { Grasses }\end{array}$ & Annuals & Total \\
\hline \multicolumn{5}{|c|}{1989} \\
\hline $\mathrm{COL}$ & 0.02 & 0.00 & 0.00 & 0.02 \\
\hline $\mathrm{LA}$ & $\cdot \quad 0.09$ & 0.00 & 0.00 & 0.09 \\
\hline LG & 0.01 & 0.00 & 0.00 & 0.01 \\
\hline LLG & 0.17 & 0.00 & 0.00 & 0.17 \\
\hline \multicolumn{5}{|c|}{1990} \\
\hline $\mathrm{COL}$ & 2.06 & 0.00 & 0.00 & 2.06 \\
\hline LA & 0.90 & 0.01 & 0.00 & 0.90 \\
\hline LG & 3.62 & 0.72 & 0.02 & 4.35 \\
\hline LLG & 1.47 & 0.00 & 0.01 & 1.48 \\
\hline \multicolumn{5}{|c|}{1991} \\
\hline $\mathrm{COL}$ & 10.80 & 0.10 & 11.69 & 22.58 \\
\hline LA & 16.89 & 0.03 & 4.08 & 21.00 \\
\hline LG & 18.98 & 2.56 & 6.73 & 28.27 \\
\hline
\end{tabular}


Table 4-5 (continued)

\begin{tabular}{|c|c|c|c|c|}
\hline LLG & 11.41 & 0.20 & 17.43 & 29.04 \\
\hline \multicolumn{5}{|c|}{1992} \\
\hline COL & 21.36 & 0.42 & 17.16 & 38.94 \\
\hline LA & 32.58 & 0.21 & 11.71 & 44.50 \\
\hline LG & 23.24 & 2.86 & 13.89 & 40.00 \\
\hline LLG & 23.55 & 1.58 & 43.17 & 68.31 \\
\hline \multicolumn{5}{|c|}{1993} \\
\hline LLG & 28.94 & 2.24 & 34.89 & 66.07 \\
\hline \multicolumn{5}{|l|}{1994} \\
\hline LLG & - & 0.17 & 4.23 & - \\
\hline
\end{tabular}

Primary production was positively correlated to precipitation in all calendar intervals (Table 4-2). SPR_WIN, GROW_YR, and WATER_YR all had a similar strong effect, explaining between 79 and 81 percent of the variation in total production. The amount of precipitation in the previous year explains 28 percent of the variation in production, a surprising amount considering the one- to two-year interval between rainfall and plant growth. Stepwise and $C_{p}$ regression analysis indicated that total productivity was best predicted using precipitation from two calendar intervals, GROW_YR and PREV_YR (Table 4-3).

Life Forms. Productivity was highly variable by life form and across years (Figure 4-13). Shrub production was greater than annual production in dry years (1989-91 and 1994), and less than annual production in wet years (1992 and 1993) (Figure 4-13 and Table 4-5). Annual plant production contributed between 0 and 42 percent to the total production across years. Annual plant production was greatest in 1992. Perennial forbs and grasses were generally minor components of production, comprising less than 4 percent of the production during the study period.

Shrub productivity was positively correlated with precipitation amounts in all five calendar intervals (Table 4-2), but was most highly correlated with precipitation during October through A'pril (GROW_YR). Stepwise regression analysis indicated that this variable explained 65 percent of the variability in shrub growth (Table 4-3). Other precipitation variables (WATER_YR, FALL_WIN, and SPR_WIN) were chosen by the stepwise regression for shrub growth, and these variables explained an additional 7 percent of the variability not explained by GROW_YR (Table 4-3). Although precipitation from the previous year (PREV_YR) also had a significant, positive correlation with shrub growth (Table 4-2), this variable was not selected by stepwise regression.

As with shrub productivity, annual plant production was positively correlated with increasing precipitation amounts for each of the rainfall calendar intervals (Table 4-2). In the stepwise regression analysis, 57 percent of the variation in the productivity of annuals was explained by precipitation during the October through September period (WATER_YR). The best stepwise regression model included only this variable, indicating that no other variable or collection of variables significantly increased the ability to predict productivity of annuals (Table 4-3). As with 


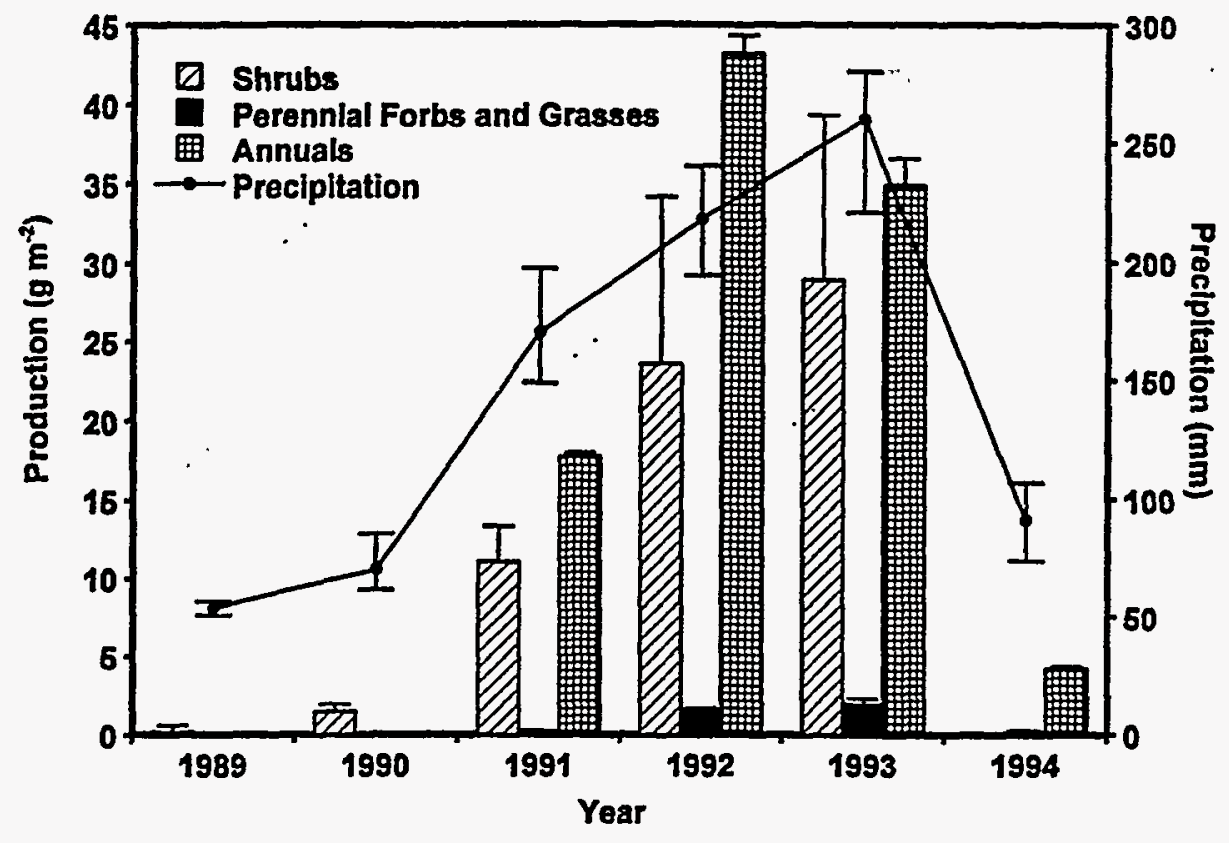

Figure 4-13. Net annual primary production ( $\mathrm{g} \mathrm{m}^{-2} \pm$ standard deviation) by life form (shrubs, perennial forbs and grasses, annual plants) during 1989 through 1994 for the LarreaLycium-Grayia (LLG) vegetation association at Yucca Mountain Nevada. Shrub production was not measured in 1994. Precipitation ( $\mathrm{mm} \pm$ standard deviation) is the total for the water year (October through September).

cover, the FALL_WIN interval, while significantly, positively correlated with productivity, did not significantly, positively increase annual growth, after the WATER_YR precipitation has been accounted for.

Vegetation Associations. Differences in productivity among vegetation associations were related to the relative productivity of different life forms in each association (Figure 4-14). Production increased across all vegetation associations from 1989 through 1992 as a result of increased precipitation. Within years, production was variable among vegetation associations (Figure 4-14). For example, in 1991 LG and LLG vegetation associations exhibited higher production than the COL and LA associations. However, in 1992 the LLG association had almost 1.5 times more production than the other vegetation associations. These differences reflect the differential response of the annual life form within a vegetation association across years (Appendix D1 through D4).

\subsection{BIODIVERSITY}

\subsubsection{Species Composition and Abundance}

One hundred species of plants were recorded on the 48 ESPs (Appendix B2). A considerable overlap in species composition existed among ESPs, but the abundance of each species was usually distinctive for each vegetation association (Figures 4-15 and 4-16). 


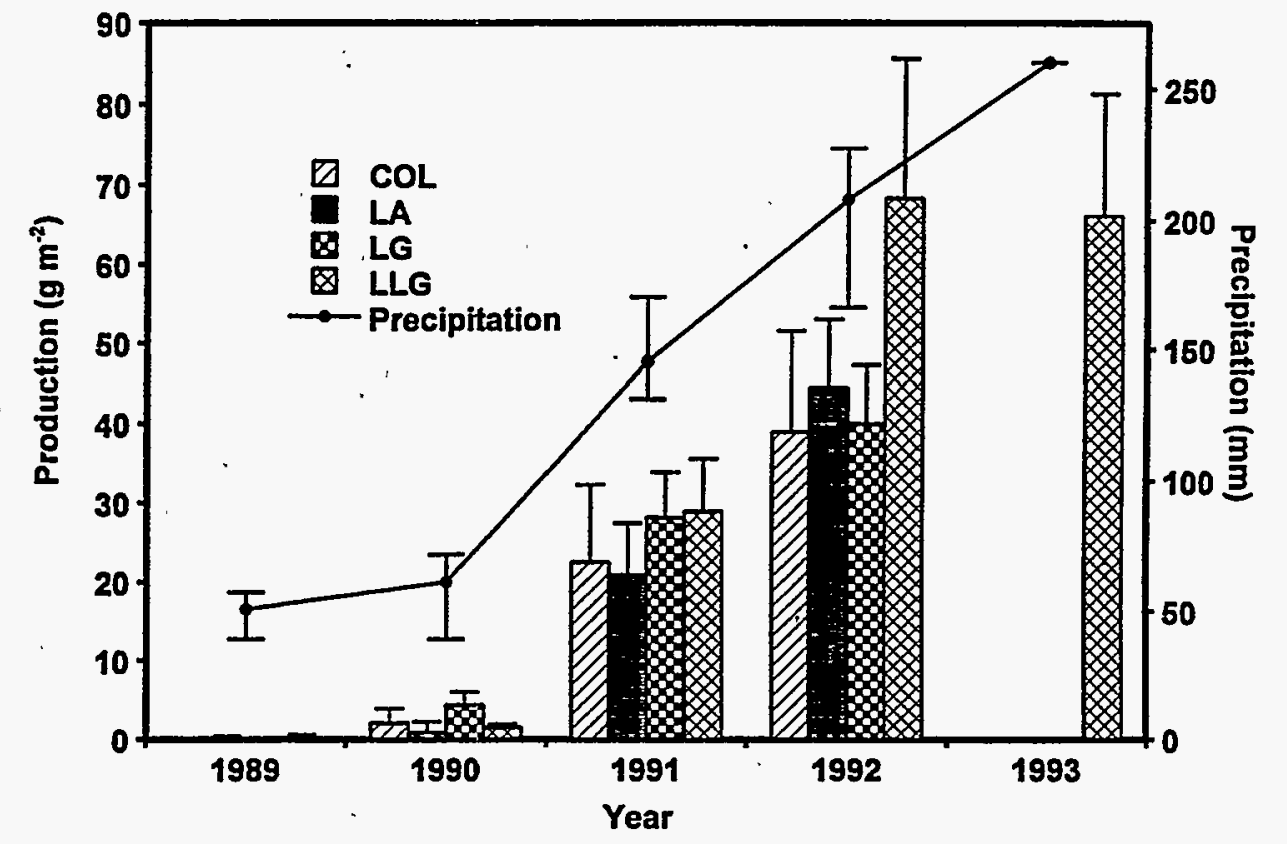

Figure 4-14. Net annual primary production ( $\mathrm{g} \mathrm{m}^{-2} \pm$ standard deviation) during 1989 through 1993 for the Coleogyne (COL), Larrea-Ambrosia (LA), Lycium-Grayia (LG) and the Larrea-Lycium-Grayia (LLG) vegetation associations at Yucca Mountain, Nevada. Production was not measured in the COL, LA, or LG associations in 1993. Precipitation ( $\mathrm{mm} \pm$ standard deviation) is the total for the water year (October through September).

Within the Coleogyne vegetation association, $C$. ramosissima was the most abundant perennial species, followed by Ephedra nevadensis and Ambrosia dumosa (Figure 4-15). The most abundant annual species were Bromus rubens, Amsinckia tesselata, and Lotus humistrus. During the six years of cover measurement, average cover of the annual species $B$. rubens was slightly less than that of the most abundant perennial species, $C$. ramosissima.

In the Larrea-Ambrosia vegetation association, A. dumosa was the most abundant perennial species over the six-year study period, comprising almost 6 percent of the ground cover. Menodora spinescens, L. tridentata, and Acamptopappus shockleyi were the next most abundant species, each comprising approximately 1.5 percent of the ground cover. Chaenactis stevioides was the most abundant annual species, with approximately 1 percent cover.

E. nevadensis, Eriogonum fasiculatum, Grayia spinosa, and Lycium andersonii were the most abundant species in the LG vegetation association with six-year average cover values ranging from 1.5 to 2.2 percent (Figure 4-16). B. rubens was the most abundant species during the study period, with an average cover of 5.1 percent, almost twice that of the most abundant perennial species. 


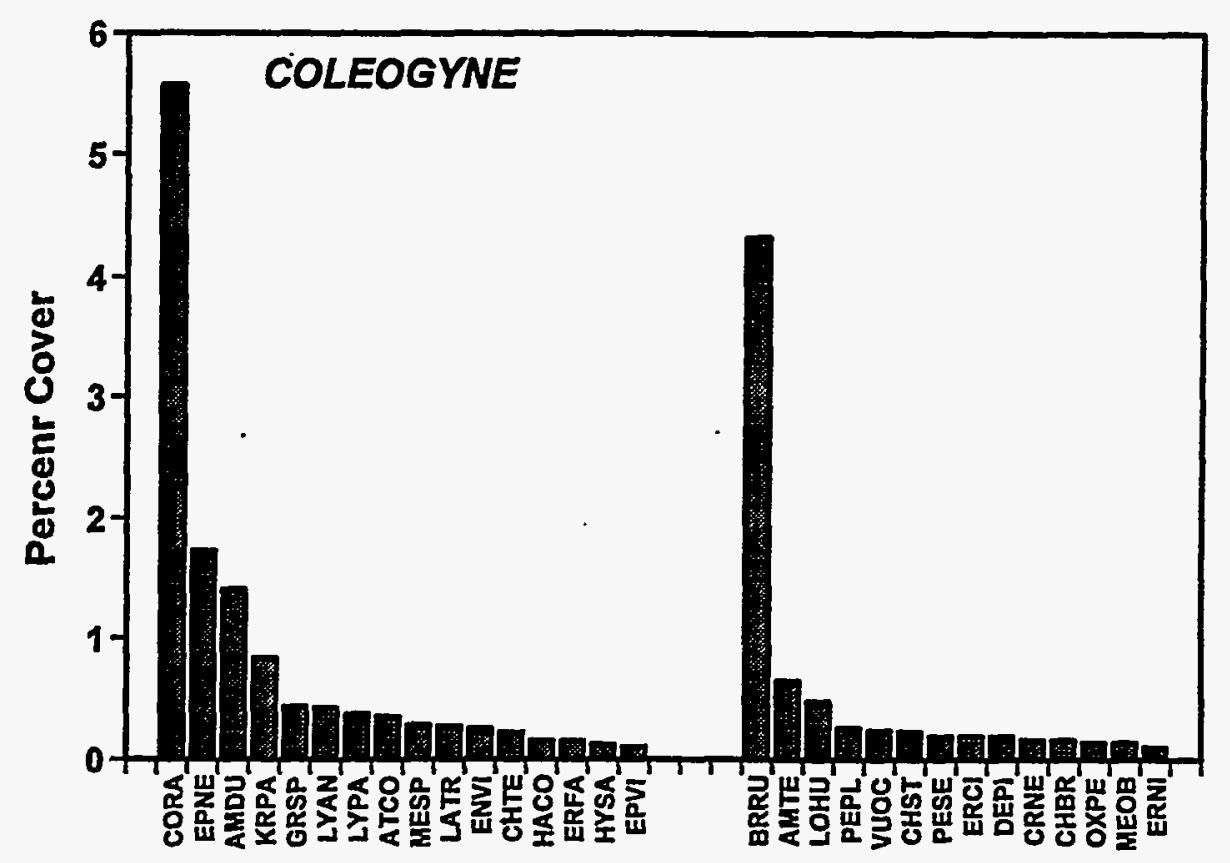

Perennials

Annuals

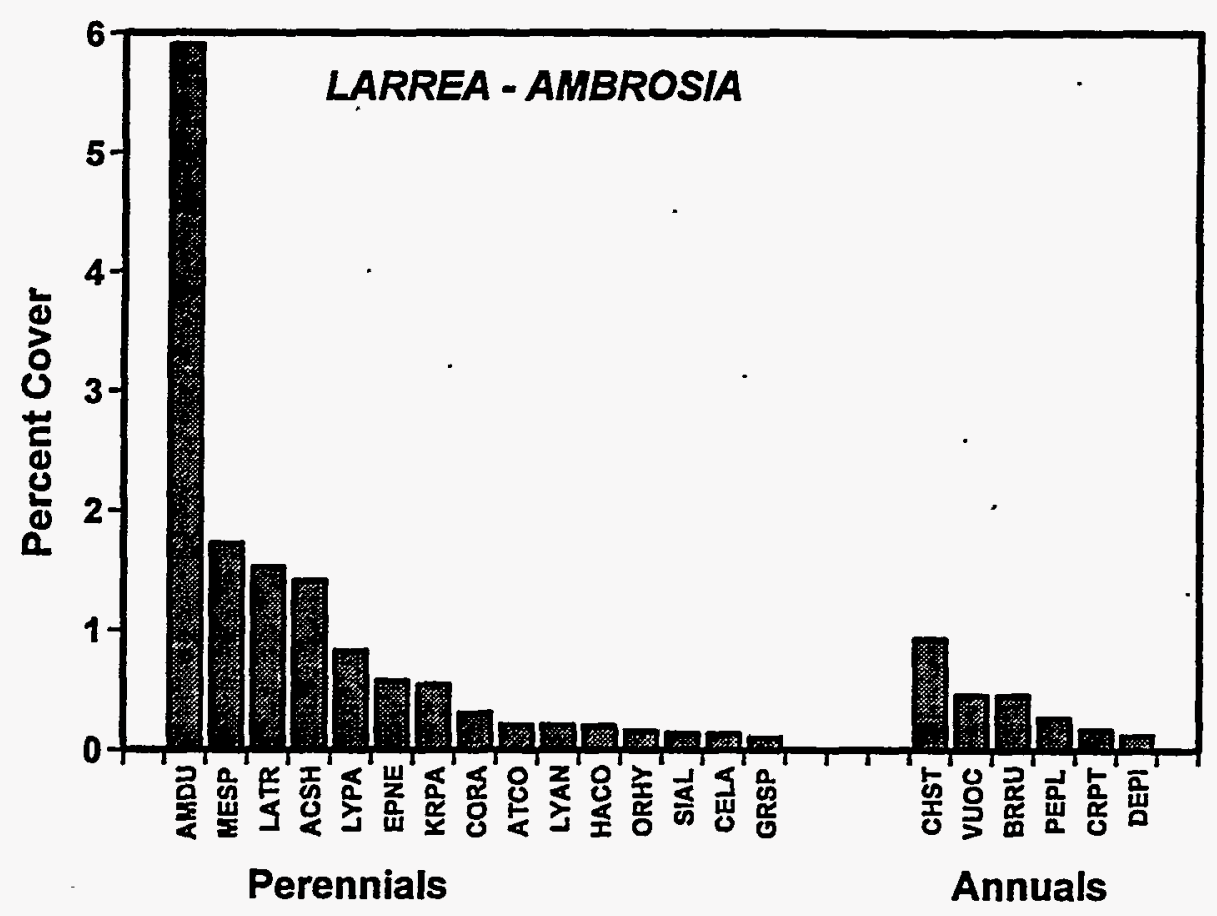

Figure 4-15. Average cover for perennial and annual species measured in the Coleogyne and Larrea-Ambrosia vegetation associations at Yucca Mountain, Nevada, from 1989 to 1994. Species shown are those found in greater than trace amounts $(0.1 \%)$. Species name codes can be found in Appendix F. Cover values for all species found in these vegetation associations can be found in Appendix B-2. 


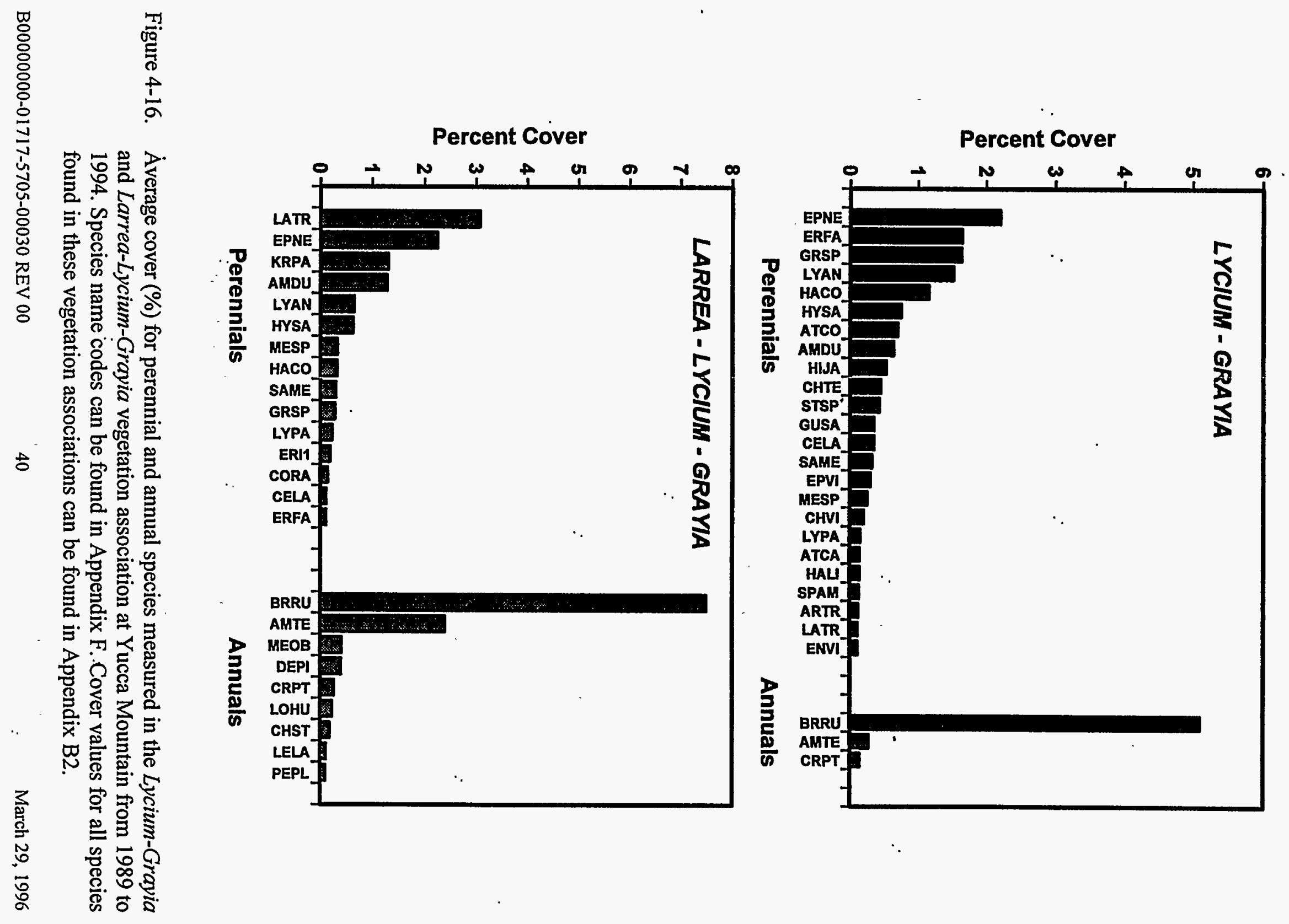


Within the LLG vegetation association, L. tridentata, E. nevadensis, Krameria erecta, and $A$. dumosa had the greatest average cover during the six-year study period (Figure 4-16). However, the annual species, $B$. rubens, had almost 2.5 times more cover than the most abundant perennial species, despite the fact that this species was not found during 1989 and 1990.

Perennial species having abundances greater than trace amounts $(<0.1 \%$ cover $)$ that were found in all vegetation associations included $A$. dumosa, $E$. nevadensis, Ericameria cooperi, $G$. spinosa, $L$. tridentata, L. andersonii, Lycium pallidum, and $M$. spinescens. Bromus rubens was the only annual species that occurred in all vegetation associations in greater than trace amounts (Appendix B2).

Several species were found in only one vegetation association. For example, Echinocereus engelmannii, Lomatium nevadense, Phlox stansburyi, and Yucca brevifolia were measured only in the COL vegetation association. Other instances include Cuscuta denticulata in the LA association, Artemisa tridentata, Atriplex polycarpa, and Muhlenbergia porterii in the LG association, and Dalea mollissima in the LLG association.

Ninety-one additional species were found at Yucca Mountain that were not recorded during cover measurements in the ESPs. All species recorded at Yucca Mountain from 1989 until 1994 are listed in Appendix F. This appendix lists the common name and authority of each species. A few additional species, usually annuals, continue to be added to the list each year.

Niles et al. (1994) listed 321 species in the greater Yucca Mountain area. Their survey covered $390 \mathrm{~km}^{-2}$ and included nearby limestone mountains and Quaternary volcanic soils not found on Yucca Mountain. Niles et al. (1995) continued their census an additional year and found an additional 51 species.

\subsubsection{Species Diversity}

Generally, as the size of the area characterized increased (i.e., from replicate to transect to ESP, etc.), diversity and species richness increased and evenness decreased (Figure 4-17). Evenness, which can be thought of as lack of dominance, was highest on individual sampling units, the 50-m replicate. Species composition became less evenly distributed as the sample size shifted from smaller to larger units. This pattern was caused by (1) low species richness on smaller sampling units, (2) lack of dominance by any species at the local scale, and (3) the ubiquity of the most common species throughout a vegetation association.

The diversity of Yucca Mountain each year (Figure 4-17, column "Years") was substantially less than the diversity of all years combined (Figure 4-17, column "All sites"), indicating that multiple years of data collection provide a more complete measurement of perennial species diversity.

Diversity varies among associations. The LG vegetation association had the most perennial species richness and highest diversity (Figure 4-18). Fifty-five perennial species were encountered during cover measurements in this vegetation association. In contrast, the LA vegetation association had the lowest diversity and the lowest number of species. The COL and LLG vegetation association had comparable diversity. 


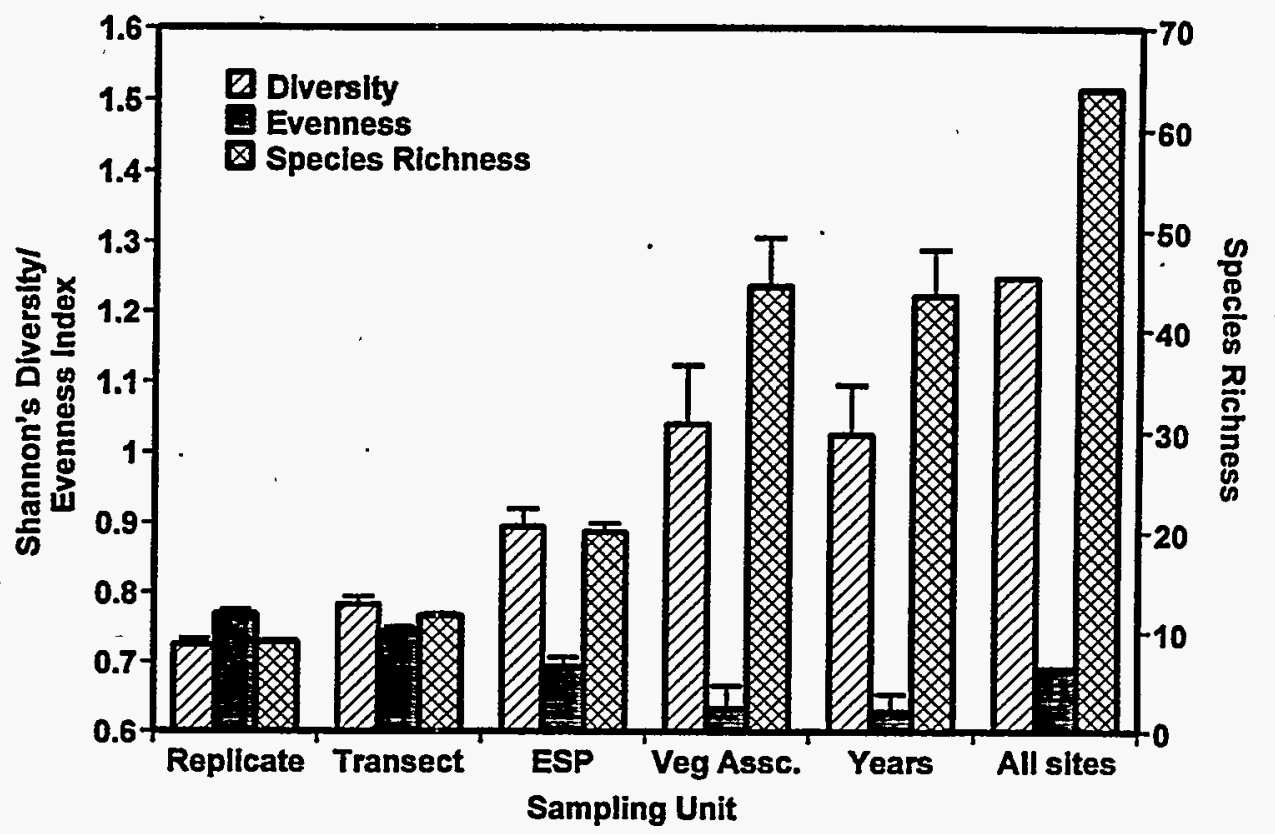

Figure 4-17. Shannon's diversity index, Shannon's evenness index, and species richness for sampling units used to measure perennial species cover at Yucca Mountain from 1989 to 1994. Error bars indicate standard errors for the sampling unit.

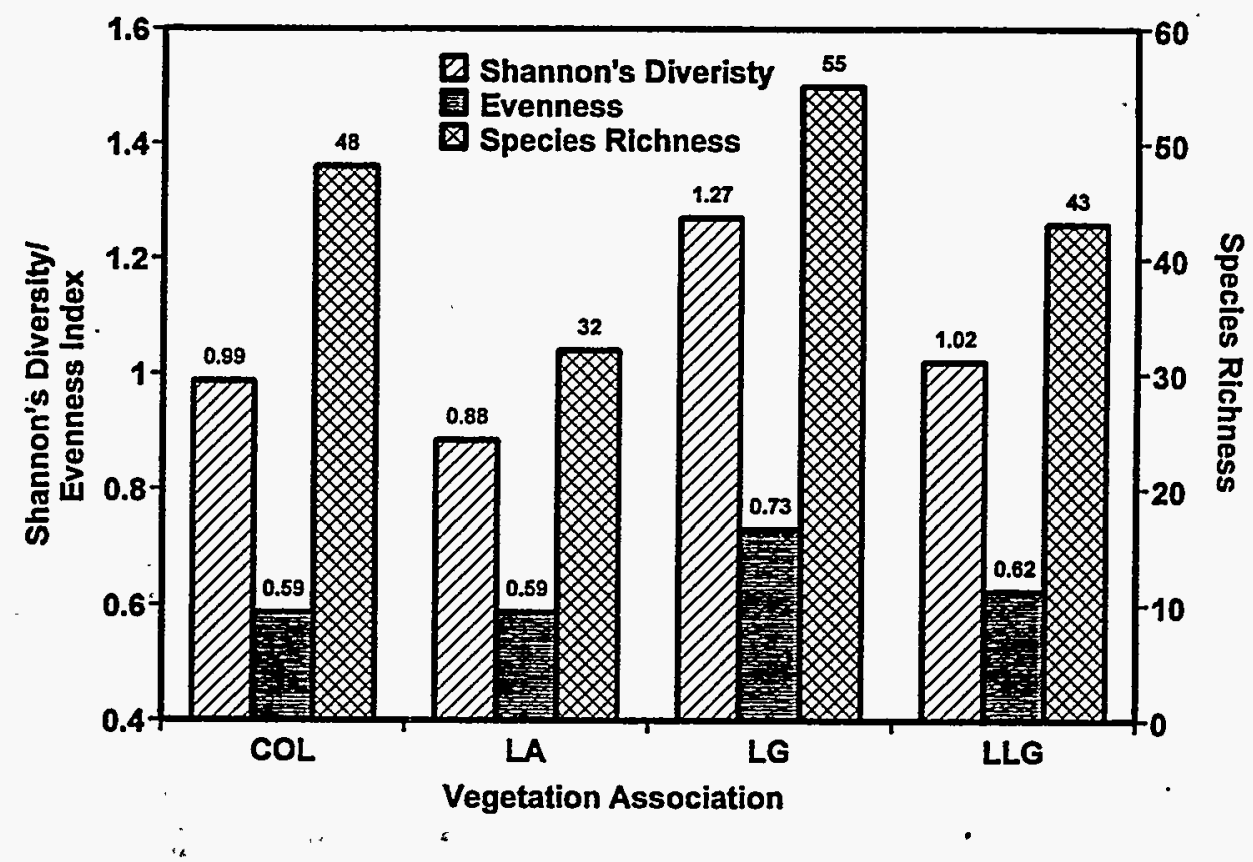

Figure 4-18. Shannon's diversity index, Shannon's evenness index, and species richness for perennial species cover within vegetation associations at Yucca Mountain from 1989 to 1994 . Vegetation associations sampled were Coleogyne (COL), Larrea-Ambrosia (LA), Lycium-Grayia (LG), and Larrea-Lycium-Grayia (LLG). 
Perennial species evenness was lowest in the COL and the LA vegetation associations. This measure was most likely caused by the dominance of Coleogyne ramosissima in the COL association and Ambrosia dumosa in the LA association (Figures 4-15 and 4-16). Unlike other Mojave Desert shrubs, Coleogyne ramosissima tends to form monotypic stands (Beatley 1976), although this is not generally true at Yucca Mountain.

\subsubsection{Species of Concern}

The U.S. Fish and Wildlife Service no longer lists any species that occur on or near the Nevada Test Site (U.S. Department of Interior, 1996). The one Category 1 candidate, Astragalus beatleyae, listed before February 28, 1996, was removed from the list based on previous work by DOE (U.S. Department of the Interior 1996).Prior to February 28, 1996, the U.S. Fish and Wildlife Service listed twelve Category 2 candidate plant species and one Category 1 candidate plant species that may occur on the Nevada Test Site (Mendoza 1995). Much work has been conducted documenting sensitive plant locations on or near the Nevada Test Site (Beatley 1977a and 1977b; Rhoads and Williams 1977; Rhoads et al. 1978; Cochrane 1979; Pinzl 1984; Knight and Smith 1994; Knight and Smith 1995; Blomquist et al. 1995). However, none of these sensitive species have been found at Yucca Mountain. The Yucca Mountain Project has conducted 165 preactivity surveys covering 1,079 separate sites to look for sensitive species and important biological resources. These preactivity surveys were conducted from 1989 through 1995 and documented no sensitive plant species. Likewise, these species have never been found on ESPs or revegetation plots .

\subsection{THE EFFECT OF THE PHYSICAL ENVIRONMENT ON VEGETATION}

The purpose of this analysis was to determine what environmental factors affect the distribution and abundance of perennial plant species. This relationship was investigated using CCA (Canonical Correspondence Analysis), computed with CANOCO software (ter Braak 1992). CCA indicated that elevation, slope, sand (percent sand in the soil), maximum temperature (12-month average), and precipitation (total from 1988 to 1994) each explained a significant $(P<0.05)$ amount of the variability in the species-ESP ordination. In other words, these environmental factors influence cover as well as species composition of each ESP.

\subsubsection{Specieș Characteristics}

In CCA, a biplot is used to depict the relationships between species and environmental factors (Figure 4-19). Individual species are represented by a four-letter species code (the first two letters of the genus and the first two letters of the species, from Appendix F). Kent and Coker (1992) and ter Braak (1986) explain CCA interpretation. Briefly, the arrows projecting from the origin depict the correlation between each environmental factor and the species-ESP ordination. The greater the length of the arrow, the greater the correlation. The arrow can also be projected backward to account for negative correlation, a step that is not depicted graphically, in order to simplify the biplot. The closer a species is located to an arrowhead, the greater the influence of the respective environmental factor. 


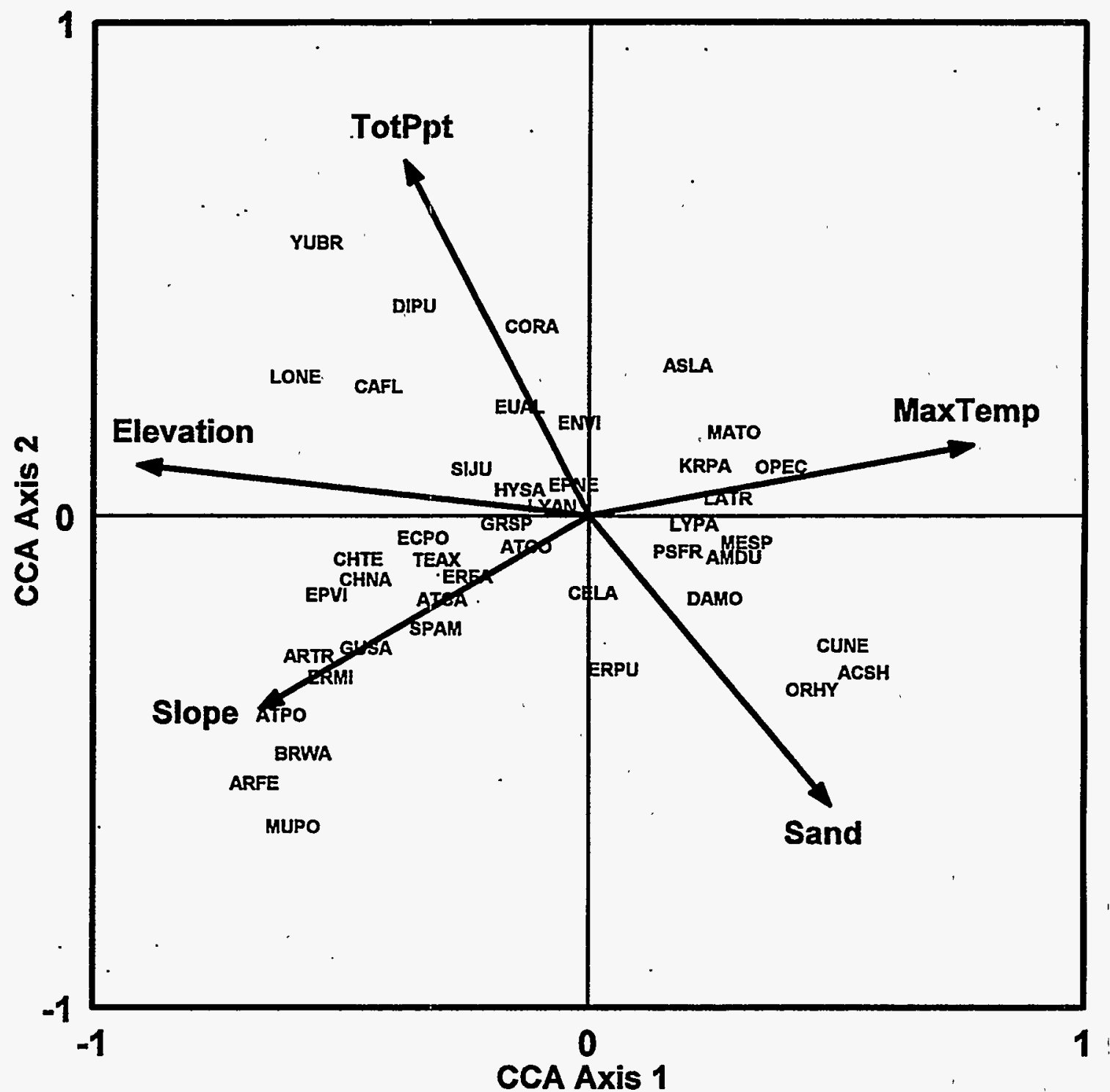

Figure 4-19. Canonical Correspondence Analysis (CCA) biplot showing the relationship between the environmental factors and species cover. The environmental factors depicted (arrows) are elevation, slope, soil (Sand), maximum temperature (MaxTemp) and total precipitation (TotPpt). Species are depicted as four-letter species codes; these codes can be found in Appendix F. Interpretation of CCA biplots is discussed in the text. 
Oryzopsis hymenoides (ORHY), Acamptopappus shockleyi (ACSH), and Cuscuta nevadensis (CUNE) were correlated with lower elevations having sandy soils (Figure 4-19). In contrast, Yucca brevifolia (YUBR), Dichelostemma pulchellum (DIPU), Lomatium nevadense (LONE), Calochortus flexuosus (CAFL), and Coleogyne ramosissima (CORA) were correlated with increasing elevations, decreased percentages of sand in the soil, and increased total precipitation. Aristida fendleriana (ARFE), Muhlénberia porteri (MUPO), Brickellia watsonii (BRWA), and Atriplex polycarpa (ATPO) were correlated with increased slopes. Species such as Atriplex confertifolia, Grayia spinosa, Lycium andersonii, Ephedra nevadensis, Salazaria mexicana, and Hymenoclea salsola that had relatively high cover values across ESPs (Appendix B2) were clustered near the origin. This fact may indicate that these species occur in a variety of ESPs and that they are not strongly influenced by a measured environmental variable.

\subsubsection{ESP Characteristics}

ESPs within the same vegetation association tend to cluster together, with a small amount of overlap. Perhaps the most important generalization from Figure 4-20, as well as the most unexpected, is that no single environmental factor overlaps the ordination space of any vegetation association. Rather, the species composition of the ESPs in an association is explained by a combination of the five environmental factors. For example, the LA association ESPs were correlated with low elevations, high average maximum temperatures, and sandy soil (these ESPs were ordinated in the lower right quadrant of the biplot). A subset of the sites was highly correlated with high elevations and steep slopes (lower left quadrant of the Figure 4-20). These sites were generally in the LG vegetation association.

\subsection{THE STRUCTURE AND DISTRIBUTION OF VEGETATION ASSOCIATIONS}

An important result of the ordination was that the original field classification of ESPs was valid, and that ESPs formed four generally distinct groups based on species composition. For example, despite considerable variation in species composition among the 12 LG ESPs, these ESPs formed a cohesive group when ordination axes were plotted (Figure 4-21).

There were exceptions where field classifications were not consistent. For example, LG5T clustered with LLG ESPs in Figure 4-21. LG5T is located at the base of a ridge (most LG ESPs are near ridge tops) at the ecotone between a lower elevation association. A second problem was lumping, placing distinct subgroups into the same association. For example, ordination shows that COL was composed of two distinct subgroups (Figure 4-21). The first subgroup is found on high-elevation ridge tops where species composition is almost entirely Coleogyne ramosissima. The remaining eight COL plots are located at lower elevations, in vegetation that is ecotonal between LA or LLG. A third problem, the reverse of lumping, was the tendency for field classification to distinguish vegetation associations where no distinct differences among ESPs exist. This tendency is observable in Figure 4-21, where ESPs from COL, LA, and LLG overlap slightly.

Further analysis of ordination results gives some insight into why these errors occur. First, each of the three major DCA axes were helpful in separating ordination groups. However, each axis explained only a small proportion of the variation in species composition among ESPs. Together, the first three axes explained 49 percent of the variation in species cover among ESPs. Axes 1 and 2 explain 25 percent and 18 percent, respectively. Axis 3 effectively separated LLG ESPs (low 


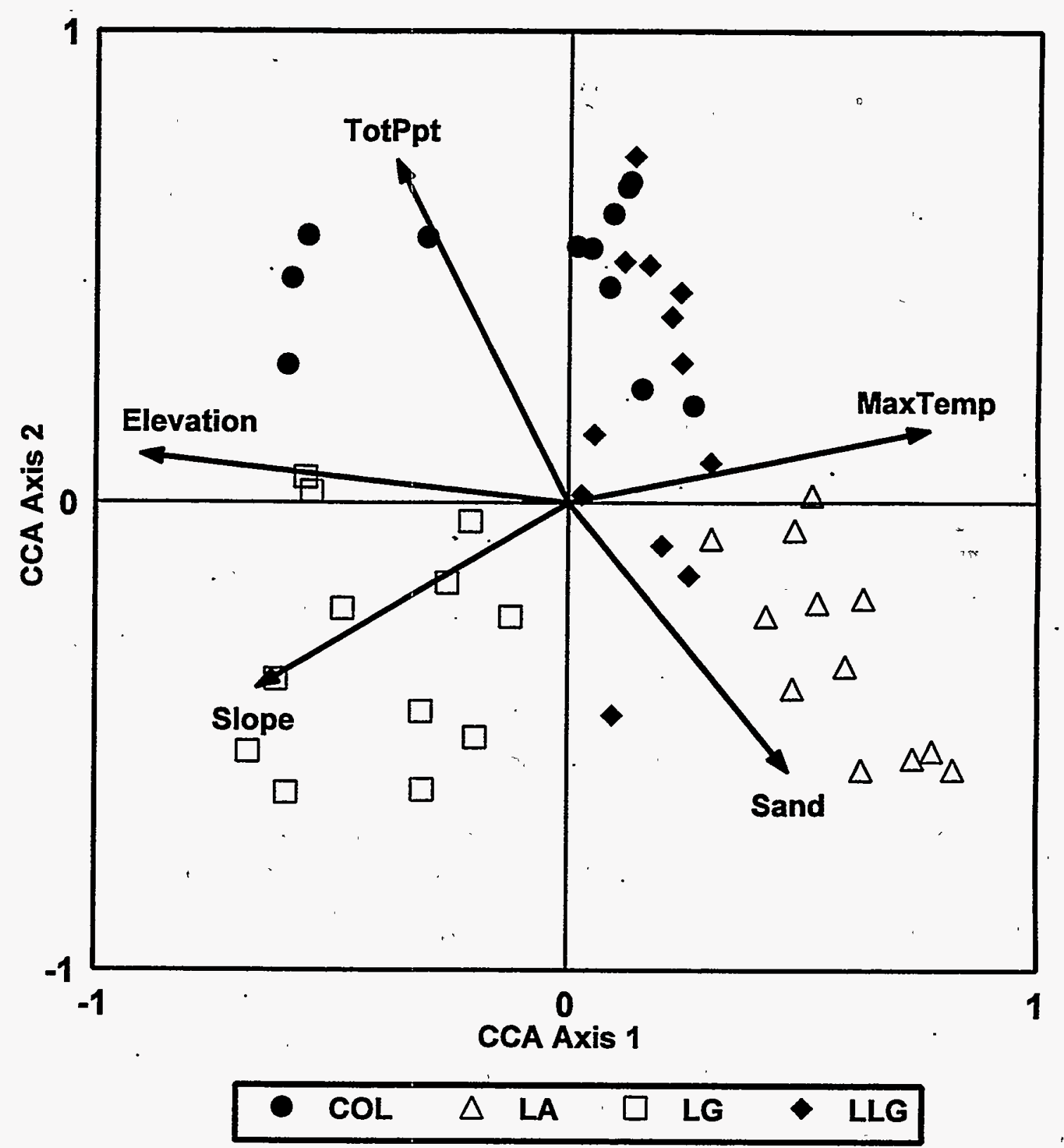

Figure 4-20. Canonical Correspondence Analysis (CCA) biplot showing the relationship between environmental factors and species composition of each Ecological Study Plot (ESP). The environmental factors depicted (arrows) are elevation, slope, soil (Sand), maximum temperature (MaxTemp) and total precipitation (TotPpt). Each ESP is coded by vegetation association (Coleogyne $=$ COL, Larrea-Ambrosic $=$ LA, LyciumGrayia $=\mathrm{LG}$, and Larrea-Lycium-Grayia=LLG). Interpretation of CCA biplots is discussed in the text. 


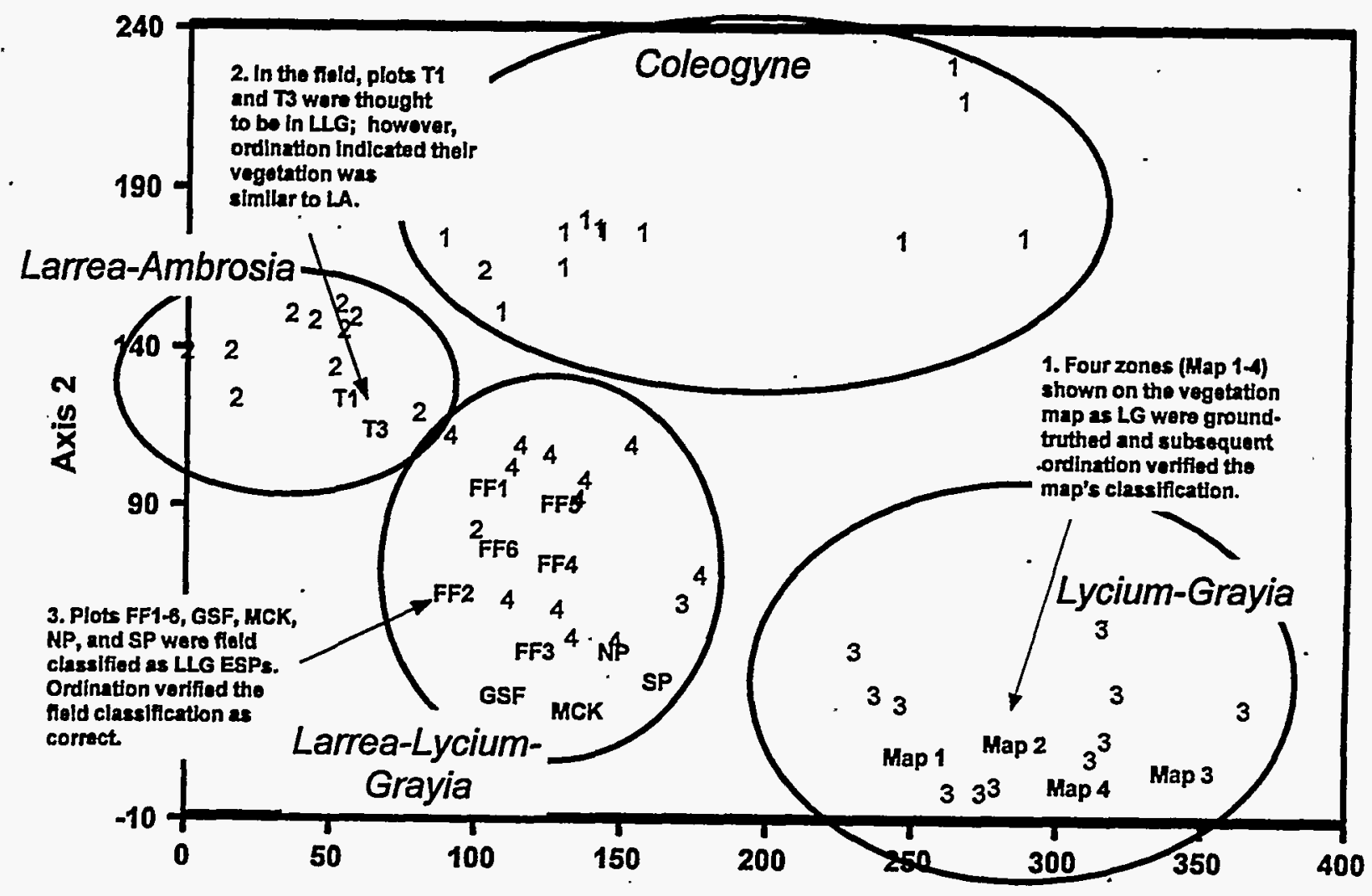

Axis 1

Figure 4-21. Detrended Correspondence Analysis (DCA) ordination of 48 Ecological Study Plots (ESPs) from four vegetation associations (Coleogyne, Larrea-Ambrosia, LyciumGrayia, and Larrea-Lycium-Grayia) at Yucca Mountain, Nevada. This graph demonstrates how multivariate statistical techniques such as DCA can be used to assess similarity in species composition. In each of the three annotated examples, cover measurements from unclassified vegetation were projected onto the ordination of the original $48 \mathrm{ESPs}$, for which the vegetation association was already known. The position of the census points, relative to the position of the known vegetation associations, was used to classify the field vegetation. The borders of each vegetation association (depicted by the drawn ovals) are subjective and overlap slightly. 
values) from the other three ESPs, even though the axis explained only about 7 percent of the total variation in species composition. The cause of these low axis loadings was that few species are found in all ESPs.

Second, the species that determined ordination groupings were not necessarily the most common or visible species. Some indication of what species impart the most weight to each axis can be determined by ordinating species rather than ESPs (performing Q-type ordination, Pielou 1984). Figure 4-22 shows the weighting of eight species on each of the first three axes of the Q-type species ordination. The species shown are the most influential in the ordination because they form the endpoints of each axis. Generally, the most influential species determining axis scores are subdominant shrubs, not necessarily the dominant shrubs. For example, the highest values of axis 1 are weighted by Chrysothamnus viscidiflorus, Gutierrezia sarothrae, Hilaria jamesii, and Chrysothamnus teretifoius, high-elevation species found on ridges. None of these species are dominant on any ESP.

Discriminant analysis correctly classified all but three of the 48 ESPs. The probability that field classification grouped ESPs by chance is close to zero. The discriminant function produced by this analysis could be used to classify any Yucca Mountain vegetation sample with an error rate of 8 percent. The analysis used the first six Principal Component Analysis axes of the ESP by species data matrix. These axes were selected because they each explain a significant $(P<0.05)$ proportion of the variation in the data matrix.

Because the results of ordination are subject to visual interpretation, ordination is not a classification technique, although there is much overlap between ordination and classification. Pielou (1984) describes several methods that use the results of ordination for classifying communities. There is much overlap between the objectives of ordination and classification. Lefkowitz (1976) classification, the simplest of Pielou's methods, is an unbiased series of rules used to group ordination results, free of subjectivity or insight, and based on the first three DCA axes. This method showed that high elevation COL, all LG, and most LLG ESPs are generally distinct, but that low elevation COL, most LA, and four LLG ESPs are difficult to classify. Inclusion of additional axes still did not differentiate these ESPs.

The ordination for the 48 ESPs can also be used to determine vegetation associations of sample data. Two sample plots (T1 and T3) were thought to be in the LLG association, based on the lack of Ambrosia dumosa (Figure 4-21, Annotation 2). However, these plots were projected closer to the LA association than to the LLG association; consequently, the plots were not classified as LLG association. Annotation 3 in Figure 4-21 show instances where field classification was verified by ordination. Annotation 1 shows an example where field classification could not be made because the high-elevation hillside contained such a wide range of species. However, these four sample plots were unambiguously projected onto the LG vegetation association (Figure 4-21, Annotation 1). 


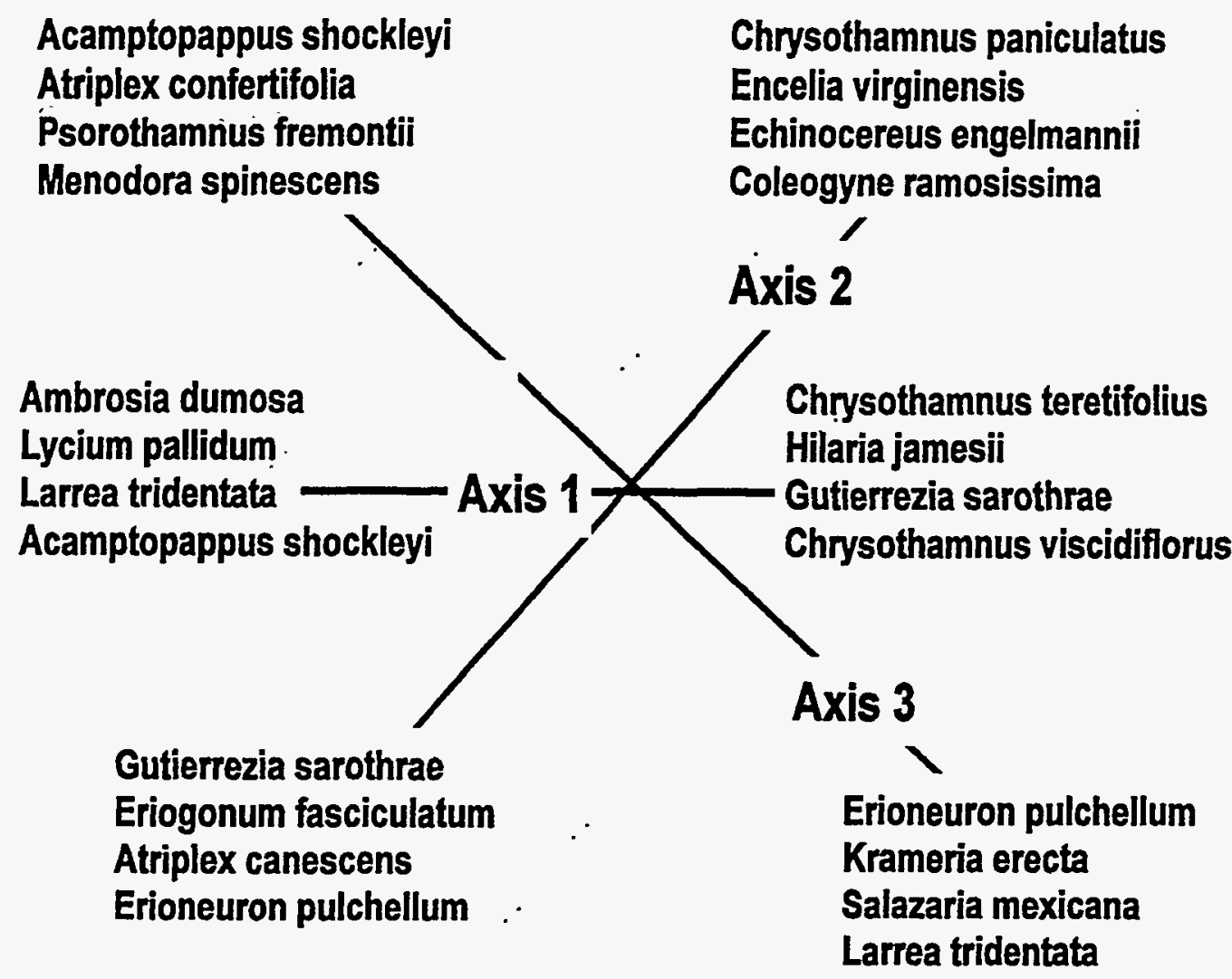

Figure 4-22. Detrended correspondence analysis (DCA) ordination of species (Q-type ordination), illustrating the most influential eight species for each ordination axis. In DCA, there is a correspondence between the axes of plot ordination and species ordination. Because of this property, the species forming the endpoints of ordination axes 1,2 , and 3 above are most influential in segregating Ecological Study Plots (ESPs) along these same axes. 
INTENTIONALLY LEFT BLANK 


\section{DISCUSSION}

\subsection{THE EFFECT OF THE PHYSICAL ENVIRONMENT ON VEGETATION}

Precipitation. The Mojave Desert differs from other North American deserts in three ways: extreme aridity, winter-spring precipitation with little summer rainfall, and unpredictable yearly precipitation (Shreve 1942). In all arid areas, precipitation becomes the foremost limiting factor of plant growth (Noy-Meir 1973), creating a yearly response of the vegetation that hides other factors likely to influence plant growth, such as soil, nutrients, temperature, competition, or grazing. While it is clear that a wet growing season on the Mojave Desert (December through April) stimulates growth of vegetation.(Beatley 1974b; Ackerman et al. 1980), it does not necessarily follow that each increase in the amount of precipitation will result in a predictable increase in growth. For example, Beatley (1974b) describes plant growth as a step model where precipitation events trigger subsequent steps. In this model, the amount of precipitation in a time interval is not important, only whether it reaches the threshold to trigger the next growth stage.

Although they were not a part of this study, anecdotal observations have accumulated that would make the relationship between plant growth and precipitation even more unpredictable. Frost damage (see also Beatley 1975), nutrient depletion, drought dormancy of shrubs, seed bank status, and herbivory (Hunter et al. 1980) all reduce plant growth, particularly when precipitation and growth are high.

Several other studies have attempted to clarify the relationship between precipitation and productivity. Lauenroth and Sala (1992) found that 40 percent of the variation in production on the Colorado short grass prairie could be explained by precipitation. This finding is particularly interesting in light of the fact that there is little yearly variation in the small rainfall events that provide most of the annual precipitation (Sala et al. 1992). Using historical records from the same short grass prairie, Milchunas et al. (1994). found that a combination of rainfall, grazing, and edaphic factors explained 61 percent of the variation in plant productivity. In their model, 33 percent of the variation was explained by precipitation-related variables. In arid zones in Australia, rainfall explained between 26 and 69 percent of the variability in productivity, depending upon the time interval, which ranged from 1 month to 36 months. Knapp (1995) used measures of precipitation and temperature to predict the incidence of wildfires in the Intermountain West of North America. In the semiarid ecosystems studied, increases in precipitation increased the amount of vegetation, which subsequently raised the likelihood of wildfire. This increase was accentuated in areas where introduced annual grasses such as Bromus predominated. Seasonal precipitation explained as much as 51 percent of the variation in wildfire incidence.

The extensive writings of Janice Beatley on the flora and fauna of the Mojave Desert and the Nevada Test Site emphasize the complex relationship between climate and flora. Beatley (1974a) argued that the distribution of Larrea tridentata is determined by a combination of winter aridity and warm winters, and that the absence of $L$. tridentata from enclosed flats on the Nevada Test Site is caused by the lack of cold air drainage and not by interspecific competition or other biotic factors. Beatley has shown (1969a and 1969c) that the productivity of annuals is highly correlated with patterns of rainfall (as opposed to total rainfall), and that rainfall pattern creates the fundamental division between Mojave and Great Basin Deserts. 
Beatley emphasized that past precipitation may have a greater effect on productivity than recent precipitation, and she specifically argued that autumn rainfall (October through November) was necessary for spring growth (March through May). Beatley clarified that the importance of this interval was not to increase vegetative growth, but to stimulate germination and break drought dormancy in perennials. Unfortunately, Beatley offered no statistical analysis of this theory.

Precipitation, Calendar Interval, and Life Form. The relationship between plant growth and precipitation depended upon all three factors used in the regression analysis: calendar interval, life form, and response variable(cover versus production). It was difficult to compare response variable because cover was measured over six years, rather than four years for production.

Life forms did not respond similarly to precipitation, but these differences are confounded by the response variable being measured. For example, shrub production was positively correlated with precipitation, but shrub cover was negatively correlated with precipitation. Annual cover was more highly correlated with precipitation than annual production. The significance of these differences between cover and productivity are not understood and may simply reflect the differences in the number of yearly censuses.

Assessing the influence of each calendar interval was more straightforward. Precipitation from FALL_WIN and PREV_YR both had a weak, but positive, effect on plant growth. Precipitation falling in either SPR_WIN, GROW_YR, or WATER_YR had similar effects and strongly stimulated plant growth. It would be easy to explain this similarity on the basis of overlap among the three calendar intervals, but this explanation is not sufficient. On average, over all ESPs and years, SPR_WIN supplied only 60 percent of the precipitation in a WATER_YR. Yet precipitation falling in SPR_WIN explained 91 percent of the variation in the amount of precipitation falling in WATER_YR. This high correlation between precipitation in different intervals is most likely the result of the boom and bust pattern of rainfall in the Mojave Desert. The climate of southern Nevada is characterized by periods of wet and dry conditions lasting at least one year and usually less than five years (Houghton et al. 1975). If fall is wet, chances are that winter and spring will be wet also.

A final comparison among calendar intervals can be made between the linear and squared functions; that is, whether SPR_WIN or (SPR_WIN) ${ }^{2}$ was selected for the best regression model. All of the models in Table 4-3 included at least one squared function. In most cases, plant growth is best explained by an exponential, curvilinear function of several intervals.

The Effect of Precipitation on Vegetation. Several conclusions can be drawn from the regression analysis that give some insight into the relationship between precipitation and plant growth at Yucca Mountain. First, a large proportion of the variation in plant growth -42 percent of cover and 16 percent of production - could not be explained by precipitation. This variation occurred because the pattern of precipitation, especially the gaps between precipitation events, may have been as influential as the total amount of precipitation during the same interval. Unexplained variation in plant growth also includes all biotic factors, such as seed bank status, herbivory (and rodent and lagomorph population cycles), and competitive interactions.

Second, the FALL_WIN interval was influential, even though actual growth was minimal during this time. However, this interval did not have the overriding importance that Beatley (1974b) described. An alternate hypothesis would explain Beatley's observations, as well as those reported 
here. The hypothesis distinguishes between amount of vegetation and species composition. FALL_WIN rain determines species composition, but GROW_YR precipitation determines amount of growth. Beatley herself supplied evidence for this hypothesis when she observed that groups of species; often in the same family, germinated in différent calendar intervals, given adequate precipitation (Beatley 1974b). The Polemoniaceae, Hydrophyllaceae, Polygonaceae, Leguminosae, and the Onagraceae germinated after fall rains, while the Cruciferae and Boraginaceae germinated after December rains when the soil was considerably cooler. Shrubs also reached peak productivity at different times. Ambrosia and Lycium reached peak productivity in late winter or early spring, whereas Larrea and Krameria reach peak productivity in late spring or early summer (Ackerman 1980).

Third, the best regression models usually included squared transformations, indicating that plant growth responds exponentially and nonlinearly to increases in precipitation. This indication is similar to Beatley's (1974b) anecdotal observation that plant growth is either "successful" or not, with few years of intermediate growth. Ultimately, this bimodal pattern of plant growth is a reflection of southern Nevada's boom and bust climate, where there are as many wet and dry years as moderate years.

Finally, plant growth was stimulated by growing conditions in the previous year. The most likely biological explanation was that plants in drought dormancy were less able to respond to favorable conditions than plants that were physiologically active the previous year. The positive influence from the previous year was surprising because several ecological processes would produce the opposite pattern. For example, nutrient depletion is known to occur in desert ecosystems (Ettershank et al. 1978; Fisher et al. 1988; James and Jurinak 1978; Romney et al. 1978) and would begin to decrease growth after several consecutive wet years. Nutrient depletion was suspected of causing a decrease in cover in 1993, despite a slight increase in precipitation over 1992. Also, competition for space and light should limit growth. Competitive interactions are probably minimal after a drought, but should intensify after each consecutive year of high precipitation and high growth.

Environmental Factors. Elevation was the most highly correlated variable in the canonical correspondence analysis. The correlation of elevation with species-ESP ordination indicated that there are large differences in the soil and microclimate between the crest of Yucca Mountain $(1509 \mathrm{~m})$ and Jackass Flats $(1036 \mathrm{~m})$. Species compositional differences along this gradient were evident in the CCA biplot for perennial species (Figure 4-19). Species such as Coleogyne ramosissima, Yucca brevifolia, Dichelostemma pulchellum, and Lomatium nevadense had the greatest abundances on sites at high elevations, while $A$. shockleyi and Oryzopsis hymenoides had greatest abundance at low elevations, indicating the habitat preferences for these species.

Across ESPs, soils, slope, precipitation and temperature were important factors influencing species composition and abundance. Each of these, in some way, is related to elevation. For instance, the amount of clay in soil is a result of increased weathering of parent material and advanced soil formation. Parent material is eroded by water (precipitation) and freeze-thaw cycles (temperature). At the higher elevations at Yucca Mountain, temperatures are generally lower and precipitation is generally greater than at lower elevations (Quiring 1983). Therefore, although all five environmental factors help shape the pattern and distribution of plant species at Yucca Mountain, elevation is an uitimate factor, strongly moderated by the proximate effects of precipitation, soil, temperature, and slope. 
Successful reclamation planning depends on knowing the most suitable species for reintroduction, as well as the environmental factors that affect each species. Information from CCA analysis can be directly applied to reclamation efforts at Yucca Mountain. By examining the species biplot in Figure 4-19, the reclamation potential of species for specific environmental conditions, such as high elevation or sandy soil, can be determined.

\subsection{THE STRUCTURE AND DISTRIBUTION·OF VEGETATION ASSOCIATIONS}

Describing vegetation in terms of associations has great predictive power, but only if it can be shown that the associations are true vegetation units that retain their integrity over time and distance. A better understanding of.Yucca Mountain plant associations is needed for several purposes. First, vegetation association is a blocking factor in the statistical model being used to assess potential impacts of site characterization activities on vegetation (Hessing et al. in preparation), and interpretation of the model will depend upon association cohesiveness. Second, vegetation data from ESPs are being used to evaluate a vegetation map of Yucca Mountain (EG\&G/EM 1995) that will form a benchmark for future remote sensing and provide a baseline for assessing vegetation change. Third, the U.S. Geological Survey is modeling ground water infiltration at Yucca Mountain. Evapotranspiration is one of the most influential parameters of the model (Hevesi and Flint 1993). Knowing where and how plant associations vary across the Yucca Mountain landscape will help understand how vegetation communities influence evapotranspiration and infiltration (Leary 1990; Smith et al. 1995).

\subsubsection{Previous Classification at Yucca Mountain}

Beatley's (1976). description of the vegetation associations did not always match the species composition at Yucca Mountain (O'Farrell and Collins 1984). While ESPs generally fit Beatley's classification, the dominant species were neither consistent within associations, nor did they match Beatley's description. Table 5-1 lists information designed to compare our results with Beatley's. In most cases, Beatley listed only the dominant species and the associated species and did not include proportional data. The vegetation association that O'Farrell and Collins (1984) labeled LG, a designation retained in this study, most closely matches Beatley's (1976) GL (Grayia-Lycium) association.

Beatley's descriptions of Mojave Desert vegetation association appear to have a great deal of universality throughout the Mojave Desert. Her classification was used by Webb et al. (1987) in the Panamint Mountains of California. Additional reports make it clear that groups of species co-occurring on the Nevada Test Site are found throughout the Mojave Desert (Carpenter et al. 1986; Vasek and Barbour 1977). 
Table 5-1. Comparison of Beatley's (1976) plant associations with Ecological Study Plot (ESP) species composition at Yucca Mountain, Nevada. Only perennial shrubs and grasses with at least $2 \%$ relative cover are listed. Beatley described species composition qualitatively, represented here by the following codes: D - Dominant, CD - Codominant, A Associated species, $\mathrm{E}$ - found at the ecotone of the association.

\begin{tabular}{|c|c|c|c|}
\hline Beatley Composition & Beatley Code & ESP Composition & $\begin{array}{c}\% \text { Relative } \\
\text { Cover } \\
\end{array}$ \\
\hline \multicolumn{4}{|c|}{ Coleogyne Vegetation Association } \\
\hline Coleogyne ramosissima & $\mathrm{D}$ & Coleogyne ramosissima & 33.6 \\
\hline Ephedra nevadensis & A & Ambrosia dumosa & 18.1 \\
\hline Chrysothamnus teretifolius & $\mathrm{A}$ & Ephedra nevadensis & 14.3 \\
\hline Artemisia spp. & E & Lycium pallidum & 6.7 \\
\hline Grayia spinosa & $\underline{E}$ & Krameria erecta & 6.1 \\
\hline Larrea tridentata & E & Larrea iridentata & 4.2 \\
\hline Yucca brevifolia & $\mathrm{E}$ & Encelia virginensis & 3.7 \\
\hline Lycium andersonii & E & Lycium andersonii & 3.2 \\
\hline Airiplex confertifolia & E & & \\
\hline Menodora spinescens & $\mathrm{E}$ & & \\
\hline \multicolumn{4}{|c|}{ Larrea-Ambrosia Vegetation Association } \\
\hline Larrea Iridentala ${ }^{\circ}$ & $\mathrm{D}$ & Ambrosia dumosa & 49.5 \\
\hline Ambrosia dumosa & $\mathrm{D}$ & Larrea tridentata & 14.1 \\
\hline Krameria erecla & $\mathrm{A}$ & Lycium pallidum & 8.9 \\
\hline Ephedra nevadensis & $\mathrm{A}$ & Acamplopappus shockleyi & 4.2 \\
\hline Krascheninnikovia lanata & $\mathrm{A}$ & Ephedra nevadensis & 3.0 \\
\hline Acamplopappus shockleyi & $\mathrm{A}$ & Krameria erecia & 2.5 \\
\hline Menodora spinescens & A & Coleogyne ramosissima & 2.5 \\
\hline Psorothamnus fremontii & $\mathrm{A}$ & & \\
\hline \multicolumn{4}{|c|}{ Lycium-(iravia Vegetation Association (Beatley's Grayia-Lycium) } \\
\hline S.ycizm andersonii & $\mathrm{CD}$ & Ephedra nevadensis & 13.9 \\
\hline Grayia spinosa & $C D$ & Grayia spinosa & 11.9 \\
\hline Atriplex canescens & $\mathrm{A}$ & Eriogonum fasciculatum & 9.8 \\
\hline Krascheninnikovia lanata & $\mathrm{A}$ & Lycizum andersonii & 9.0 \\
\hline Tetradumia glabrata & $\mathrm{A}$ & Ericameria cooperi & 8.2 \\
\hline Arlemisià spinescens & $\mathrm{A}$ & Hymenoclea salsola & 6.8 \\
\hline Atriplex confertifolia & $\mathrm{A}$ & Ambrosia dumosa & 6.3 \\
\hline Acamplopappus shockleyi & A & Hilaria jamesii & 5.1 \\
\hline Chrysothammus viscidiflorus & $\mathrm{A}$ & Atriplex confertifolia & 4.3 \\
\hline Ephedra nevadensis & A & Gutierrezia sarothrae & 3.0 \\
\hline
\end{tabular}


Table 5-1 (continued)

\begin{tabular}{|l|c|l|r|}
\hline \multicolumn{1}{|c|}{ Beatley Composition } & Beatley Code & \multicolumn{1}{c|}{ ESP Composition } & $\begin{array}{c}\text { \% Relative } \\
\text { Cover }\end{array}$ \\
\hline Tetradymia axillaris & A & Krascheninnikovia lanata & 3.0 \\
\hline Yucca brevifolia & A & Chrysothamnus teretifolitus & 2.0 \\
\hline & & Atriplex canescens & 2.0 \\
\hline \multicolumn{2}{|c|}{ Larrea-Lycium-Gravia Vegetation Association } & $\cdot$ \\
\hline Larrea tridentata & CD & Larrea tridentata & 31.8 \\
\hline Lycium andersonii & CD & Ephedra nevadensis & 17.6 \\
\hline Grayia spinosa & CD & Ambrosia dumosa & 13.0 \\
\hline Ericameria cooperi & A & Krameria erecta & 8.3 \\
\hline Yucca brevifolia & A & Hymenoclea salsola & 7.9 \\
\hline Ambrosia dumosa & A & Salazaria mexicana & 3.9 \\
\hline Psorothamnus fremontii & A & Lycium andersonii & 3.3 \\
\hline Krameria erecta & A & Lycium pallidum & 3.3 \\
\hline Ephedra nevadensis & A & Menodora spinescens & 2.0 \\
\hline Oryzopsis hymenoides & A & & \\
\hline
\end{tabular}

\subsubsection{Ordination}

Importance of Subdominants. The importance of subdominants (Figure 4-22) explains to some extent the discrepancies between field classification and ordination. Field classification is based on dominant species, while ordination weighs each species in proportion to its cover. For example, the presence of Larrea, regardless of its abundance, may indicate to an observer in the field that vegetation is Mojavean rather than Great Basin transitional. Ordination, however, attaches no more importance to Larrea than to any other species.

The finding that subdominants were responsible for the cohesiveness of vegetation associations concurs with recent research by Tueller et al. (1991). These researchers used ordination to determine where species composition changed along an elevation gradient from desert to Pinon-Juniper woodland in northwestern Nevada. They found that the points along the transect where the entire community changed most distinctly were not necessarily the points where the dominant species changed. El-Ghonemy et al. (1980a) classified vegetation at Rock Valley on the Nevada Test Site and found that several associations lacked a dominant species altogether.

Cohesiveness. The purpose of this ordination analysis was to assess the extent to which field classification formed discrete vegetation units. This objective differs from a priori classifications that randomly sample the entire landscape, such as El-Ghonemy et al. (1980a). Although the concepts of plant communities, habitat types, and vegetation associations are commonly used in applied ecological research (Bourgeron 1988), these concepts are best viewed as useful tools rather than discrete units (Barbour et al. 1980). The general correspondence between quantitative field 
classification and ordination at Yucca Mountain, and the close grouping of most ESPs when ordinated, shows that discrete vegetation associations can be identified. Soils play a large role in determining the distribution of Mojave Desert species (El-Ghonemy et al. 1980a and 1980c; Smith and Nowak 1990), and this factor alone could explain similarities among species composition over broad areas. The influence of other abiotic factors such as elevation, precipitation, and temperature are constant over wide areas and probably reinforce the co-occurrence of species into vegetation associations in the Mojave Desert.

The results show that classification into vegetative associations can at times be inaccurate. Several types of discrepancies between field classification and ordination were described that appear to have a common cause. Field classification relies on the composition of the dominant species, often just one or two species, whereas ordination weighs all species. Not all ESPs within the same vegetation association share a similar species composition. This lack of distinctness of each vegetation association was minimized in this analysis, but will be a much larger problem for vegetation mapping. This difficulty arises because the 48 ESPs were stratified within vegetation associations and transitional zones were under represented. Randomly sampled vegetation might be misclassified much more frequently.

Vegetation Mapping and Sampling. The ability of ordination to separate vegetation associations on the basis of species composition leads to several insights about how communities should be sampled for classification. Cover is an adequate measure of ecological importance; time consuming measurements, such production or density, are not necessary. The most important piece of information on each species is whether it is present or not. Consequently, species identification is important. Because of this, it might be best to develop a classification that lumps species of the same genus that are difficult to distinguish, such as Chrysothamnus or Lycium. Accuracy of measurement (e.g., whether Ambrosia dumosa has 20 or 25 percent cover) is unimportant (because ESPs with wide ranges of cover values, but with similar species, are similarly classified). For the purpose of mapping or ground truthing, it might be possible to adequately classify vegetation by visually estimating the cover of each species within regularly placed quadrats.

\subsubsection{Mortality and Recruitment}

There are problems associated with determining mortality and recruitment in the Mojave Desert that may not be encountered in other biomes, or even in other deserts. In the Mojave Desert it is difficult to determine whether a plant is alive, because plants typically lose their leaves and become photosynthetically inactive during droughts, such as the period 1989 to 1990 that encompassed the first two years of this study. Also, population dynamics will probably differ dramatically between wet and dry years. The two wettest years of research (1992 and 1993) coincided with mortality and recruitment measurement. Finally, mortality and recruitment are inherently variable. Two consecutive years of measurement may not be adequate to measure these attributes. For example, Platt et al. (1988) censused mortality yearly for 10 years before reporting life history characteristics of a southern pine.

Measurements of mortality and recruitment in the LLG vegetation association at Yucca Mountain support the viewpoint of a dynamic community where individuals die and are replaced gradually but continually. This view was first documented on the Mojave Desert by Beatley (1980). She stressed the stability of the species composition despite 14 percent mortality and 19 percent recruitment 
during the 12 years separating her censuses. Her measurements are slightly lower than ours. Beatley observed 1.2 percent yearly mortality versus 2.7 percent at Yucca Mountain (the two-year average from Figure 4-12), and she observed 1.6 percent yearly recruitment versus 3.2 percent at Yucca Mountain.

Seedling Recruitment. Ackerman (1979) observed the long-term seedling survival of only one individual, prompting him to question how seedling recruitment can maintain population size. A likely answer is episodic or pulse recruitment, where long-term recruitment is restricted to infrequent episodes of extended wet, warm, or otherwise favorable conditions. Romney et al. (1980) determined the age of young Artemisia shrubs on the Nevada Test Site by counting growth rings and concluded that recruitment was limited to three "pulses" in a 12-year period. 


\section{CONCLUSIONŚ}

1. The cover, production and species composition of vegetation at Yucca Mountain is extremely variable from year to year. Much of this variability-58 percent of cover and approximately 80 percent of production-is determined by precipitation. Patterns of plant growth are therefore highly unpredictable, despite being well understood.

2. The amount of precipitation falling on an ESP was a function of (1) yearly climate conditions, (2) the vegetation association, and (3) the spatial location of the ESP. The soil moisture tracked precipitation events. Soil profiles that were uniformly and consistently wet during the winter and spring produced abundant plant growth. Soil at $45 \mathrm{~cm}$ depth retained moisture over long intervals and may explain consistent plant growth despite erratic and sporadic precipitation events.

3. The amount of vegetative growth depends on the total amount of precipitation received during seven months (October 1 to May 1) regardless of when it falls within this interval. However, the balance between annuals and perennials, and the annual species composition, changed dramatically depending upon the pattern of precipitation.

4. Life form composition varied among years; annuals fluctuated from being absent to providing more than half of the ground cover and productivity. Life form composition also varied among vegetation associations. Measurement techniques, especially percent cover, may not accurately reflect changes in the major life forms equally well.

5. The flora of Yucca Mountain is diverse; 100 species were measured during cover and density censuses, and an additional 91 species were observed in the area impacted by the SCEP. Diversity and richness (but not evenness), increased steadily along a gradient of increasing area.

6. There are no threatened and endangered species, or candidate species, at Yucca Mountain.

7. Communities at Yucca Mountain are structured into vegetation associations. Vegetation associations found in one area can be identified predictably, with a low error rate, across the Yucca Mountain landscape. However, there is variation in species composition within associations, and transition zones are present. Classification and identification of vegetation associations using ordination depends upon subdominant and occasional species as much as the dominant species.

8. The vegetation found at a location is a predictable consequence of environmental factors, including elevation, lithology, precipitation, temperature, and slope.

9. Mortality, juvenile recruitment, and seedling recruitment were low and variable from 1992 to 1993. Much more measurement is needed to determine the yearly variation in population dynamics. 
INTENTIONALLY LEFT BLANK 


\section{REFERENCES}

Ackerman, T.L. 1979. "Germination and Survival of Perennial Plant Species in the Mojave Desert." Southwestern Naturalist. 24:399-408.

Ackerman, T.L.; Romney, E.M.; Wallace, A.; and Kinnear, J.E. 1980. "Phenology of Desert Shrubs in Southern Nye County, Nevada." Great Basin Naturalist Memoirs. 4:4-23.

Aitchison, J. 1986. The Statistical Analysis of Compositional Data. London: Chapman and Hall.

Amer, S.A.; Keefer, T..O.; Weltz, M.A.; Goodrich, D.C.; and Bach, L.B. 1994. "Soil Moisture Sensors for Continuous Monitoring." Water Resources Bulletin. 30:69-83.

Angerer, J.P.; Ostler, W.K.; Gabbert, W.D.; and Shultz, B.W. 1994. Secondary Plant Succession on Disturbed Sites at Yucca Mountain, Nevada. Report No.11265-1118. Santa Barbara, California: EG\&G/EM Santa Barbara Operations.

Bamberg, S.A.; Vollmer, A.T.; Kleinkopf, G.E.; and Ackerman, T.L. 1976. "A Comparison of Seasonal Primary Production of Mojave Desert Shrubs During Wet and Dry Years." American Midland Naturalist. 95:398-405.

Barbour, M.G.; Burk, J.H.; and Pitts, W.D. 1980. Terrestrial Plant Ecology. Menlo Park, California: Benjamin Cummings Publishing Company.

Beatley, J.C. 1969a. "Biomass of Desert Winter Annual Plant Populations in Southern Nevada." Oikos. 20:261-273.

Beatley, J.C. 1969b. "Dependence of Desert Rodents on Winter Annuals and Precipitation." Ecology. 50:721-724.

Beatley, J.C. 1969c. Vascular Plants of the Nevada Test Site, Nellis Air Force Range, and Ash Meadows. Los Angeles, California: University of California.

Beatley, J.C. 1974a. "Effects of Rainfall and Temperature on the Distribution and Behavior of Larrea tridentata (Creosote-bush) in the Mojave Desert of Nevada." Ecology. 55:245-261.

Beatley, J.C. 1974b. "Phenological Events and Their Environmental Triggers in Mojave Desert Ecosystems." Ecology. 55:856-863.

Beatley, J.C. 1975. "Climates and Vegetation Pattern Across the Mojave/Great Basin Desert Transition of Southern Nevada." American Midland Naturalist. 93:53-70.

Beatley, J.C. 1976. Vascular Plants of the Nevada Test Site and Central-Southern Nevada: Ecologic and Geographic Distributions. TID-26881, UC-11. Springfield, Virginia: Technical Information Center, Office of Technical Information, Energy Research and Development Administration. 
Beatley, J.C. 1977a. Endangered Plant Species of the Nevada Test Site, Ash Meadows, and CentralSouthern Nevada. COO-2307-11. Las Vegas, Nevada: U.S. Energy Research and Development Administration, Nevada Test Site.

Beatley, J.C. 1977b. Threatened Plant Species of the Nevada Test Site, Ash Meadows, and CentralSouthern Nevada. COO-2307-12. Las Vegas, Nevada: U.S. Energy Research and Development Administration, Nevada Test Site.

Beatley, J.C. 1980. "Fluctuation and Stability in Climax Shrub Woodland Vegetation of the Mojave, Great Basin, and Transition Deserts of Southern Nevada." Israel Journal of Botany. 28:149-168.

Blomquist, K.W.; Lindemann, T.A.; Lyon, G.E.; Steen, D.C.; Wills, C.A.; Flick, S.A.; and Ostler, W.K. 1995. Current Distribution, Habitat, and Status of Category 2 Candidate Plant Species on and Near the U.S. Department of Energy's Nevada Test Site. Report No. 11265-1149, UC-708. Las Vegas, Nevada: EG\&G/EM, Las Vegas Area Operations.

Bonham, C.D. 1989. Measurements of Terrestrial Vegetation: New York, New York: John Wiley \& Sons, Inc.

Bourgeron, P. 1988. "Advantages and Limitations of Ecological Classification for the Protection of Ecosystems." Conservation Biology. 2:218-219.

Carpenter, D.E.; Barbour, M.G.; and Bahre, C.J. 1986. "Old Field Succession in Mojave Desert Scrub." Madrono. 33:111-122.

Cochrane, S. 1979. Status of Endangered and Threatened Plant Species on Nevada Test Site - A Survey. Parts 1 and 2. Appendix C: Collection Records for the Taxa Considered. Report No. 1183-2356. Santa Barbara, California: EG\&G/EM, Santa Barbara Operations.

Cole, K.L. and Webb, R.H. 1985. "Late Holocene Vegetation Changes in Greenwater Valley Mojave Desert California." Quaternary Research. 23:227-235.

Collins, E.; O'Farrell, T.P.; and Rhoads, W.A. 1981. Annotated Bibliography for Biologic Overview for the Nevada Nuclear Waste Storage Investigations, Nevada Test Site, Nye County, Nevada. Report No. EGG 1183-2419, Goleta, California: EG\&G/EM, Santa Barbara Operations.

Collins, E.; O'Farrell, T.P.; and Rhoads, W.A. 1982. Biologic Overview for the Nevada Nuclear Waste Storage Investigations, Nevada Test Site, Nye County, Nevada. EGG 1183-2460. Goleta, California: EG\&G/EM, Santa Barbara Operations.

DOE [U.S. Department of Energy] 1988. Site Characterization Plan, Yucca Mountain Site, Nevada Research and Development Area, Nevada. DOE/RW-0199. Washington, D.C.: Office of Civilian Radioactive Waste Management System.

DOE 1995. Site Environmental Report for Calendar Year 1994. Yucca Mountain Site, Nye County, Nevada. Las Vegas, Nevada: Yucca Mountain Site Characterization Office. 
EG\&G/EM [Energy Measurements] 1995. Vegetation Map of Yucca Mountain. Preliminary Map No. YMP-95-523.0. Las Vegas, Nevada: EG\&G/EM Yucca Mountain Site Characterization Project Spatial Analysis Section.

Eglinton, T.W. and Dreicer, R.J. 1984. Meteorological Design Parameters for the Candidate Site of a Radioactive Waste Repository at Yucca Mountain, Nevada. SAND84-0440/2. Albuquerque, New Mexico: Sandia National Laboratories.

El-Ghonemy, A.A.; Wallace, A.; and Romney, E.M. 1980a. "Multivariate Analysis of the Vegetation in a Two-Desert Interface." Great Basin Naturalist Memoirs. 4:42-58.

El-Ghonemy, A.A.; Wallace, A.; and Romney, E.M. 1980b. "Socio-ecological and Soil-Plant Studies of the Natural Vegetation in the Northern Mojave Desert-Great Basin Desert Interface." Great Basin Naturalist Memoirs. 4:73-87.

El-Ghonemy, A.A.; Wallace, A.; Romney, E.M.; and Valentine, W. 1980c. "A Phytosociological Study of a Small Desert Area in Rock Valley, Nevada." Great Basin Naturalist Memoirs. 4:59-72.

Ettershank, G.; Ettershank, J.; Bryant, M.; and Whitford, W.G. 1978. "Effects of Nitrogen Fertilization on Primary Productivity in a Chihuahuan Desert Ecosystem." Journal of Arid Environments. 1:135-139.

Fisher, F.M.; Zak, J.C.; Cunningham, G.L.; and Whitford, W.G. 1988. "Water and Nitrogen Effects on Growth and Allocation Patterns of Creosote Bush in the Northern Chihuahuan Desert." Journal of Range Management. 41:387-391.

Gabbert, W.D.; Schultz, B.W.; Angerer, J.P.; and Ostler, W.K. 1995. "Plant Succession on Disturbed Sites in Four Plant Associations in the Northern Mojave Desert." In Roundy, B.A.; McArther, E.D.; Haley, J.S.; and Mann, D.K. (Eds.), Proceedings: Wildland Shrub and Arid Land Restoration Symposium. Ogden, Utah: USDA Forest Service, Intermountain Research Station.

Gauch, H.G., Jr. 1982. Cambridge Studies in Ecology. Multivariate Analysis in Community Ecology. Cambridge, Massachusetts: Cambridge University Press.

Goldberg, D.E. and Turner, R.M. 1986. "Vegetation Change and Woody Plant Demography in Permanent Plots in the Sonoran Desert." Ecology. 67:695-712.

Green, R.A.; Cox, M.K.; Doerr, T.B.; O'Farrell, T.P.; Ostler, W.K.; Rautenstrauch, K.R.; and Wills, C.A. 1991. "Assessing Impacts on Biological Resources from Site Characterization Activities of the Yucca Mountain Project." In High Level Radioactive Waste Management, Vol. 2, Proceedings of the Second Annual International Conference. American Society of Civil Engineers, New York, New York. La Grange Park, Illinois: American Nuclear Society, Inc.

Green, R.H. 1979. Sampling Design and Statistical Methods for Environmental Biologists. New York, New York: John Wiley \& Sons. 
Hessing M.B.; Lyon G.E.; Shárp, G.A.; and Ostler, K.O. (in preparation). The Vegetation of Yucca Mountain, Nevada: Effects of Site Characterization on Vegetation. Las Vegas, Nevada: Office of Civilian Radioactive Waste Management System Management.

Hickman, J.C. 1993. The Jepson Manual; Higher Plants of California. Berkeley, California: University of California Press.

Houghton, J.G.; Sakamoto, C.M.; and Gifford, R.O. 1975. Nevada's Weather and Climate. Special Publication 2. Nevada Bureau of Mines and Geology. Reno, Nevada: Mackay School of Mines, University of Nevada.

Hunter, R.B.; Wallace, A.; and Romney, E.M. 1980. "Fencing Enhances Shrub Survival and Growth for Mojave Desert Revegetation." Great Basin Naturalist Memoirs. 4:212-215.

Hutchings, S.S. and Schmautz, J.E. 1969. "A Field Test of the Relative-Weight-Estimate Method for Determining Herbage Production." Journal of Range Management. 22:408-411.

James, D.W. and Jurinak, J.J. 1978. "Nitrogen Fertilization of Dominant Plants in the Northeastern Great Basin Desert." In West, N.E. and Skujins, J. (Eds.), Nitrogen in Desert Ecosystems. Stroudsburg, Pennsylvania: Dowden, Hutchinson, and Ross.

Kartesz, J.T. and Pankhurst, R.J. 1994. A Synonymized Checklist of the Vascular Flora of the United States, Canada, and Greenland. 2 volumes. 2nd edition. Portland, Oregon: Timber Press.

Kent, M. and Coker P. 1992. Vegetation Description and Analysis. A Practical Approach. Boca Raton, Florida: CRC Press.

Knapp, P.A. 1995. "Intermountain West Lightning-Caused Fires: Climatic Predictors of Area Burned." Journal of Range Management. 48:85-91.

Knight, T. and Smith, F. 1994. An Inventory for Rare, Threatened, Endangered, and Endemic Plants and Unique Communities on Nellis.Air Force Bombing and Gunnery Range, Clark, Lincoln, and Nye Counties, Nevada. Volume I. Las Vegas, Nevada: U.S. Department of Defense,.Department of the Air Force, Nellis Air Force Bombing and Gunnery Range.

Knight, T. and Smith, F. 1995. An Inventory for Rare, Threatened, Endangered, and Endemic Plants and Unique Communities on Nellis Air Force Bombing and Gunnery Range, Clark, Lincoln, and Nye Counties, Nevada. Volume II. Las Vegas, Nevada: U.S. Department of Defense, Department of the Air Force, Nellis Air Force Bombing and Gunnery Range.

Kovach, W.I. 1993. MVSP-A Multivariate Statistical Package for IBM PCs, Ver. 2.1. Pentraeth, Wales, United Kingdom: Kovach Computing.

Lathrop, E.W. and Archbold, E.F. 1980. "Plant Response to Los Angeles Aqueduct Construction in the Mohave Desert." Environmental Management. 4:137-148. 
Lauenroth, W.K. and Sala, O.E. 1992. "Long-Term Forage Production of North American Shortgrass." Ecological Applications. 2:397-403.

Leary, K.D. 1990. Analysis of Techniques for Estimating Potential Recharge and Shallow Unsaturated Zone Water Balance Near Yucca Mountain, Nevada. Thesis. Reno, Nevada: University of Nevada.

Lefkowitz, L.P. 1976. "Hierarchical Clustering from Principal Coordinates: An Efficient Method for Small to Very Large Numbers of Objects." Mathematical Bioscience. 31:157-174.

Mahall, B.E. and Callaway; R.M. 1991. "Root Communication Among Desert Shrubs." Proceedings of the National Academy of Science. 88:874-876.

Manly, B.F.J. 1986. Multivariate Statistical Methods: A Primer. London: Chapman and Hall.

Manning, S.J. and Barbour, M.G. 1988. "Root Systems, Spatial Patterns, and Competition for Soil Moisture Between Two Desert Subshrubs." American Journal of Botany. 75: 885-893.

McAuliffe, J.R. 1991. "Demographic Shifts and Plant Succession Along a Late Holocene Soil Chronosequence in the Sonoran Desert of Baja California." Journal of Arid Environments. 20:165-178.

McAuliffe, J.R. 1994. "Landscape Evolution, Soil Formation, and Ecological Patterns and Processes in Sonoran Desert Bajadas." Ecological Monographs. 64:111-148.

Medica, P.A.; O'Farrell, T.P.; and Collins, E. 1981. Survey of Yucca Mountain, Forty-Mile Canyon, and Jackass Flats in Nye County, Nevada for Desert Tortoise (Gopherus agassizii). EGG 1183-2438. Goleta, California: EG\&G/EM, Santa Barbara Operations.

Mendoza, C.H. 1995. U.S. Fish and Wildlife Service, Reno, Nevada. Letter to Donald R. Elle, Department of Energy, Environmental Protection Division, regarding verification of species list for the Nevada Test Site. File No. 1-5-95-SP-110. June 23.

Milchunas, D.G.; Forwood, J.R.; and Lauenroth, W.K. 1994. "Productivity of Long-Term Grazing Treatments in Response to Seasonal Precipitation." Journal of Range Management. 47:133-139.

Muller, C.H. 1940. "Plant Succession in the Larrea-Flourensia Climax." Ecology. 21:206-212.

Munz, P.A. 1934. In Shreve, F. 1942. "The Desert Vegetation of North America." Botanical Review. 8:195-246.

Niles, W.E.; Leary, P.J.; Holland, J.; and Landau, F.H. 1994. A Floristic Survey of Yucca Mountain and Vicinity, Nye County, Nevada. Las Vegas, Nevada: U.S. Department of Energy Nevada Operations Office. 
Niles, W.E.; Leary, P.J.; Holland, J.; and Landau, F.H. 1995. A Floristic Survey of Yucca Mountain and Vicinity, Nye County, Nevada. Las Vegas, Nevada: U.S. Department of Energy Nevada Operations Office.

Noy-Meir, I. 1973. "Desert Ecosystems: Environment and Producers." Annual Review of Ecology" and Systematics. 4:25-51.

Nuclear Waste Policy Act of 1982. U.S.C. § 10101 et seq. Washington, D.C.

Nuclear Waste Policy Amendments Act of 1987. U.S.C. § 10101-10270. Washington, D.C.

O'Farrell, T.P. and Collins, E. 1984. 1983 Biotic Studies of Yucca Mountain, Nevada Test Site, Nye County, Nevada. EGG 10282-2031. Goleta, California: EG\&G/EM, Santa Barbara Operations.

Pielou, E.C. 1984. The Interpretation of Ecological Data. New York, New York: John Wiley \& Sons.

Pinzl, A. 1984. Nevada's Threatened and Endangered Plant Map Book. Carson City, Nevada: Nevada State Museum.

Platt, W.J.; Evans, G.W.; and Rathbun, S.L. 1988. "The Population Dynamics of a Long-Lived Conifer (Pinus palustris)." American Naturalist. 1988:491-525.

Quiring, R.F. 1983. U.S. Department of Commerce National Oceanic and Atmospheric Administration National Weather Service. Precipitation Climatology of the Nevada Test Site. WSNSO 351-88. Las Vegas, Nevada: Nuclear Support Office.

Reichman, O.J. and Price, M.V. 1993. "Ecological Aspects of Heteromyid Foraging." In Genoways, H.H. and Brown, J.H. (Eds.), Biology of the Heteromyidae. Special Publication No. 10. Provo, Utah: Brigham Young University. The American Society of Mammalogists.

Rhoads, W.A. and Williams, M.P. 1977. Status of Endangered and Threatened Plant Species on Nevada Test Site-A Survey. Part 1: Endangered Species. Report No. 1183-2356. Santa Barbara, California: EG\&G/EM, Santa Barbara Operations.

Rhoads, W.A.; Cochrane, S.; and Williams, M.P. 1978. Status of Endangered and Threatened Plant Species on Nevada Test Site-A Survey. Part 2: Threatened Species. Report No. 1183-2356. Santa Barbara, California: EG\&G/EM, Santa Barbara Operations.

Robertson, G. 1988. "Effect of Rainfall on Biomass, Growth and Dieback of Pastures in an Arid Grazing System." Australian Journal of Ecology. 13:519-528.

Romney, E.M.; Wallace, A.; and Hunter, R.B. 1978. "Plant Response to Nitrogen Fertilization in the Northern Mojave Desert and Its Relationship to Water Manipulation." In West, N.E. and Skujins, J. (Eds.), Nitrogen in Desert Ecosystems. Stroudsburg, Pennsylvania: Dowden, Hutchinson, and Ross. 
Romney, E.M.; Wallace, A.; and Hunter, R.B. 1980. "The Pulse Hypothesis in the Establishment of Artemisia Seedlings at Pahute Mesa, Nevada." Great Basin Naturálist Memoirs. 4:28-30.

Roundy, B.A.; Winkel, V.K.; Khalifa, H.; and Mathias, A.D. 1991. "Soil Water Availability and Temperature Dynamics after One-Time Heavy Cattle Trampling and Land Imprinting." Arid Soil Research and Rehabilitation. 6:53-69.

Rundel, P.W. and Gibson, P. 1996. Ecological Communities and Processes in a Mojave Desert Ecosystem: Rock Valley, Nevada. Cambridge, Massachusetts: Cambridge University Press.

Sala, O.E.; Lauenroth, W:K.; and Parton, W.J. 1992. "Long-Term Soil Water Dynamics in the Shortgrass Steppe." Ecology. 73:1175-1181.

Santos, P.F.; Elkins, N.Z.; Steinberger, Y.; and Whitford, W.G. 1984. "A Comparison of Surface and Buried Larrea Tridentata Leaf Litter." Ecology. 65:278-284.

Schultz, B.W. and Ostler, W.K. 1995a. "Effects of Prolonged Drought on Vegetation Associations in the Northern Mojave Desert." In Roundy, B.A.; McArther, E.D.; Haley, J.S.; and Mann, D.K. (Eds.), Proceedings: Wildland Shrub and Arid Land Restoration Symposium. Ogden, Utah: USDA Forest Service, Intermountain Research Station.

Schultz, B.W. and Ostler, W.K. 1995b. "Species and Community Response to Above Normal Precipitation Following Prolonged Drought at Yucca Mountain, Nevada." In Roundy, B.A.; McArther, E.D.; Haley, J.S.; and Mann, D.K. (Eds.), Proceedings: Wildland Shrub and Arid Land Restoration Symposium. Ogden, Utah: USDA Forest Service, Intermountain Research Station.

Shreve, F. 1942. "The Desert Vegetation of North America." Botanical Review. 8:195-246.

Silvertown, J. and Wilson, J.B. 1994. "Community Structure in a Desert Perennial Community." Ecology. 75:409-417.

Smith, S.D.; Herr, C:A.; Leary, K.L.; and Piorkowski, J.M. 1995. "Soil-Plant Water Relations in a Mojave Desert Mixed Shrub Community: A Comparison of Three Geomorphic Surfaces." Journal of Arid Environments. 29:339-351.

Smith, S.D. and Nowak, R.S. 1990. "Ecophysiology of Plants in the Intermountain Lowlands." In Osmand, B.C.; Pitelka, L.F.; and Hidy, G.M. (Eds.), Plant Biology of the Basin and Range. Berlin: Springer - Verlag.

Soholt, L.F. 1973. "Consumption of Primary Production by a Population of Kangaroo Rats Dipodomys Merriami in the Mojave Desert." Ecological Monographs. 43:357-376.

Sokal, R.R. and Rohlf, F.J. 1981. Biometry. 2nd ed. San Francisco, California: W.H. Freeman and Company. 
Spaulding, W.G. 1990. "Vegetational and Climatic Development of the Mojave Desert: The Last Glacial Maximum to the Present." In Betancourt, J.L.; Martin, P.S.; and Van Devender, T.R. (Eds.), Fossil Packrat Middens. Tucson, Arizona: University of Arizona.

Spaulding, W.G. and Graumlich, L.J. 1986. "The Last Pluvial Climatic Episodes in the Deserts of Southwestern North America." Nature. 320:441-444.

Strojan, C.L.; Randall, D.C.; and Turner, F.B. 1987. "Relationship of Leaf Litter Decomposition Rates to Rainfall in the Mojave Desert." Ecology. 68:741-744.

ter Braak, C.J.F. 1986. “Canonical Correspondence Analysis: A New Eigenvector Technique for Multivariate Direct Gradient Analysis." Ecology. 67:1167-1179.

ter Braak, C.J.F. 1992. CANOCO - a FORTRAN Program for Canonical Community Ordination. Ithaca, New York: Microcomputer Power.

Tueller, P.T.; Tausch, R.J.; and Bostick, V. 1991. "Species and Plant Community Distribution in a Mojave Great Basin Desert Transition." Vegetatio. 92:133-150.

Turner, F.B.; and Randall, D.C. 1989. "Net Productivity by Shrubs and Winter Annuals in Southern Nevada." Journal of Arid Environments. 17:23-26.

Turner, R.M. 1990. "Long-Term Vegetation Change at a Fully Protected Sonoran Desert Site." Ecology. 71:464-477.

U.S. Department of Interior 1995. Precipitation Data for Water Years 1992 and 1993 from a Network of Nonrecording Gages at Yucca Mountain, Nevada. Open-File Report 95-146. Denver, Colorado: U.S. Geological Survey

U.S. Department of Interior 1996. Endangered and Threatened Wildlife and Plants; Review of Plant and Animal Taxa That Are Candidates for Listing as Endangered or Threatened Species. Federal Register-61: no. 40.

Underwood, A.J. 1993. "The Mechanics of Spatially Replicated Sampling Programmes to Detect Environmental Impacts in a Variable World." Australian Journal of Ecology. 18:99-116.

Van Devender, T.R.; Thompson, R.S.; and Betancourt, J.L. 1987. "Vegetation History of the Deserts of Southwestern North America: The Nature and Timing of the Late Wisconsin-Holocene Transition." In Ruddiman, W.F. and Wright, H.E.J. (Eds.), North America and Adjacent Oceans During the Last Deglaciation. Boulder, Colorado: Geological Society of America.

Vasek, F.C. 1980. "Early Successional Stages in Mojave Desert Scrub Vegetation." Israel Journal of Botany. 28:133-148.

Vasek, F.C. and Barbour, M.G. 1977. "Mojave Desert Scrub Vegetation." In Barbour, M.G. and Major, J. (Eds.), Terrestrial Vegetation of California. New York, New York: John Wiley \& Sons. 
Wallace, A. 1980. "Soil-Plant-Animal Relationships Bearing on Revegetation and Land Reclamation in Nevada Deserts." Great Basin Naturalist Memoirs. 4:1-3.

Wallace, A. and Romney, E.M. 1972. U.S. Atomic Energy Commission Office of Information Services Technical Report. Radioecology and Ecophysiology of Desert Plants at the Nevada Test Site. TID-25954. Springfield, Virginia: National Technical Information Service, U.S. Department of Commerce.

Webb, R.H.; Steiger, J.W.; and Turner, R.M. 1987. "Dynamics of Mojave Desert Shrub Assemblages in the Panamint Mountains, California." Ecology. 68:478-490.

Webb, W.L.; Szarek, S.; Lauenroth, W.; Kinerson, R.; and Smith, M. 1978. "Primary Productivity and Water Use in Native Forest, Grassland, and Desert Ecosystems." Ecology. 59:1239-1247.

Weisberg, S. 1980. Applied Linear Regression. New York, New York: John Wiley \& Sons, Inc.

Went, F.W. 1942. "The Dependence of Certain Annual Plants on Shrubs in Southern California Deserts." Bulletin of the Torrey Botanical Club. 69:100-114.

Wentworth, T.R. 1981. "Vegetation in Limestone and Granite in the Mule Mountains, Arizona." Ecology. 62:469-482.

Wentworth, T.R. and Davidson, E.A. 1987. "Foliar Mineral Elements in Native Plants on Contrasting Rock Types: Multivariate Patterns and Nutrient Balance Regulation." Soil Science. 144:190-201. 


\section{APPENDIX A}

Average monthly precipitation $(\mathrm{mm})$ for each vegetation association at Yucca Mountain, Nevada, from 1988 to 1994 . Data from 1988 to 1990 were estimated from U.S. Geological Survey weather stations. Each vegetation association is the average of 12 Ecological Study Plots. 


\section{APPENDIX A}

Average monthly precipitation (mm) for the Coleogyne (COL), Larrea-Ambrosia (LA), Lycium-Grayia (LG), and Larrea-LyciumGrayia (LLG) vegetation associations at Yucca Mountain, Nevada, from 1988 to 1994. Data from 1988 to 1990 were estimated from U.S. Geological Survey weather stations. Each vegetation association is the average of 12 Ecological Study Plots.

\begin{tabular}{|c|c|c|c|c|c|c|c|c|c|c|c|c|}
\hline $\begin{array}{l}\text { Vegetation } \\
\text { Association }\end{array}$ & JAN & FEB & MAR & APR & MAY & JUN & JUL & AUG & SEP & OCT & NOV & DEC \\
\hline \multicolumn{13}{|c|}{1988} \\
\hline COL & 16.33 & 14.58 & 0.63 & 48.50 & 11.88 & 0.00 & 1.38 & 11.83 & 9.50 & 0.00 & 0.46 & 1.29 \\
\hline $\mathbf{L A}$ & 23.00 & 13.00 & 0.00 & 36.00 & 5.00 & 0.00 & 52.00 & 0.00 & 8.00 & 0.00 & 2.00 & 0.00 \\
\hline LG & 9.67 & 18.67 & 0.33 & 47.88 & 9.67 & 0.00 & 3.00 & 13.67 & 9.33 & 0.00 & 0.33 & $2.00^{\circ}$ \\
\hline LLG & 14.67 & 15.75 & 0.08 & 46.83 & 9.25 & 0.00 & 1.75 & 15.83 & 8.33 & 0.00 & 0.04 & 1.58 \\
\hline \multicolumn{13}{|c|}{1989} \\
\hline $\mathrm{COL}$ & 1.29 & 6.29 & 0.83 & 0.00 & 6.67 & 0.17 & 0.00 & 24.50 & 5.17 & 1.17 & 0.00 & 0.75 \\
\hline $\mathbf{L A}$ & 2.00 & 2.00 & 1.00 & 0.00 & 14.00 & 7.00 & 0.00 & 8.00 & 3.00 & 1.00 & 0.00 & 0.00 \\
\hline LG & 1.00 & 7.33 & 0.00 & 0.00 & 5.67 & 0.00 & 0.00 & 29.33 & 11.00 & 4.00 . & 0.00 & 0.00 \\
\hline LLG & 1.42 & 7.08 & 0.50 & 0.00 & 7.00 & 0.00 & 0.00 & 28.00 & 8.50 & 2.50 & 0.00 & 0.83 \\
\hline \multicolumn{13}{|c|}{1990} \\
\hline $\mathrm{COL}$ & 10.29 & 2.83 & 1.75 & 7.83 & 14.63 & 2.25 & 13.13 & 8.13 & 9.18 & 11.56 & 0.30 & 3.86 \\
\hline $\mathbf{L A}$ & 8.00 & 2.00 & 0.00 & 3.00 & 6.00 & 0.00 & 16.00 & 2.00 & 1.03 & 18.72 & 0.43 & 3.26 \\
\hline LG & 8.67 & 2.33 & 1.33 & 7.33 & 12.00 & 1.33 & 10.67 & 4.33 & 11.67 & 11.21 & 0.38 & 4.00 \\
\hline LLG & 9.08 & 2.50 & 0.67 & 5.83 & 13.25 & 3.50 & 18.58 & 2.50 & 12.67 & 13.17 & 0.18 & 4.46 \\
\hline \multicolumn{13}{|c|}{1991} \\
\hline $\mathrm{COL}$ & 3.67 & 0.11 & 60.05 & 18.44 & 10.83 & 2.62 & 0.97 & 21.28 & 14.98 & 4.35 & 2.28 & 6.39 \\
\hline LA & 2.05 & 0.00 & 50.46 & 15.68 & 5.08 & 1.16 & 2.60 & 19.95 & 15.95 & 1.21 & 4.11 & 4.73 \\
\hline LG & 2.03 & 0.00 & 45.38 & 14.22 & 7.73 & 2.16 & 0.00 & 21.24 & 24.25 & 4.63 & 0.74 & 4.09 \\
\hline LLG & 2.27 & 0.02 & 59.15 & 25.13 & 8.28 & 2.24 & 0.13 & 27.98 & 27.88 & 3.54 & 2.25 & 5.19 \\
\hline
\end{tabular}




\begin{tabular}{|c|c|c|c|c|c|c|c|c|c|c|c|c|}
\hline $78^{\circ} 0$ & $0 t^{\circ} 6$ & ES I & $\$ I^{\circ} 0$ & $9 S^{\prime} I$ & $00^{\circ} 0$ & $9 Z^{\circ} I$ & $\varepsilon 6.0 \mathrm{I}$ & $s Z^{\circ} \phi$ & $8 L^{\circ} \mathrm{OI}$ & $7 S^{\circ} \angle I-$ & $18^{\circ} 02$ & 971 \\
\hline $16^{\circ} 0$ & $\varepsilon 6^{\circ} 0 \mathrm{I}$ & $10^{\circ} \mathrm{Z}$ & $68^{\circ} 0$ & $\phi \varepsilon^{\circ} 0$ & $\nabla \tau^{\circ} 0$ & $I \varepsilon^{\prime} I$ & OI.0I & $6 L^{\circ} \varepsilon$ & $86^{\circ} \varepsilon I$ & $8 L \div I$ & $66 \mathrm{ZI}$ & DT \\
\hline $99^{\circ} 0$ & $\angle 0^{\circ} \mathrm{S}$ & $\varepsilon 6^{\circ} 0$ & $6 \mathrm{I}^{\circ} 0$ & $E 6^{\circ} \mathrm{I}$ & $00^{\circ} 0$ & $6 L^{\circ} 0$ & 6201 & $89^{\circ} I$ & $76^{\circ} 9$ & $96^{\circ} \mathrm{ZI}$ & $60^{\circ} 9 I$ & $\mathrm{VT}$ \\
\hline $19^{\circ} 0$ & $87^{\circ} 01$ & $62^{\circ} 0$ & $\angle I^{\circ} Z$ & IS'O & $90^{\circ} 0$ & $\phi \tau^{\circ} I$ & SS'IZ & $I \mathcal{E}^{\circ} \mathrm{S}$ & LLLII & $6 \varepsilon^{\circ} \varepsilon Z$ & t0.0z & 100 \\
\hline \multicolumn{13}{|c|}{$t 66 I$} \\
\hline $81^{\circ} 0 \mathrm{I}$ & $29^{\circ} \mathrm{S}$ & 6001 & $\$ 8^{\circ} \mathrm{Z}$ & $6 I^{\circ} \mathrm{Z}$ & $t I^{\circ} 0$ & $90^{\circ} \nabla I$ & $8 \mathrm{I}^{\circ} 0$ & $2 S^{\circ} 6$ & $28 \angle 2$ & $S L 6 S$ & $S E L L$ & 577 \\
\hline$\varepsilon Z^{\prime} 8$ & $9 Z^{\circ} \mathrm{S}$ & $50 \circ 01$ & $E S^{\circ} S$ & $\nabla \tau^{\circ} \varepsilon$ & $50^{\circ} 0$ & $0 E^{\prime} 8 I$ & $90^{\circ} 0$. & $26^{\circ} 01$ & $90^{\circ} \mathrm{LZ}$ & $8 \mathrm{I}^{\circ} \mathrm{IS}$ & $E 0^{\circ} \angle S$ & 57 \\
\hline$\varepsilon t^{\circ}$ I I & $E D^{\prime} S$ & $60^{\circ} \mathrm{L}$ & $6 S^{\circ} \varepsilon$ & $88^{\circ} \mathrm{I}$. & $80^{\circ} 0$ & S8:t I & $8 I^{\circ} 0$ & SEO & $6 \varepsilon^{\circ} 9 t$ & $0 z^{\circ} 9 t$ & $\angle t 89$ & $\mathbf{V T}$ \\
\hline ZS'I I & $2 \varepsilon^{\circ} t$ & $29^{\circ}$ II & 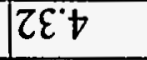 & $\mathrm{II}^{\circ} \mathcal{E}$ & $90^{\circ} 0$ & $20^{\circ} 9 I$ & $\varepsilon Z^{\circ} 0$ & $\angle I^{\circ} I Z$ & $\forall L L^{\circ} S I$ & 10009 & IES'Z8 & T0D \\
\hline \multicolumn{13}{|c|}{ E66I } \\
\hline$\varepsilon 6 . t S$ & $66^{\circ} \mathrm{II}$ & $00^{\circ} 0$ & $\varepsilon 0^{\circ} 0$ & $16 \mathrm{~L}$ & $06^{\circ} I$ & $\varepsilon S^{\prime} I$ & $6 I^{\circ} t$ & $869 \varepsilon$ & $6 S^{\circ} 9 \varepsilon$ & $196^{\circ} \mathrm{ZL}$ & $1 \angle \angle D$ & DTT \\
\hline $9 \varsigma^{\circ} t b$ & $E 0^{\circ}$ I I & $100^{\circ} 0$ & $\varepsilon 0^{\circ} 0$ & 188 & $I L^{\circ} 0$ & $\varepsilon \nabla^{\circ} 0$ & $0 S^{\circ} \varepsilon$ & SE' IE & $8 z^{\circ} 6 t$ & $E E^{\circ} \leftarrow L$ & loz zt & 97 \\
\hline$\angle 0^{\circ} Z D$ & $6 I^{\circ} 6$ & $00^{\circ} 0$ & $\varepsilon 0^{\circ} 0$ & $2 S^{\circ} \varepsilon$ & $\angle 8^{\circ} I$ & $S 0^{\circ} Z$ & Sti I & $6 L 8 Z$ & $8 t^{\circ} I \varepsilon$ & $\$ 9^{\circ} \varepsilon S$ & $S Z^{\circ} \subseteq \mathcal{E}$ & $\mathbf{V T}$ \\
\hline$\forall S^{\circ} \angle S$ & $E S^{\circ} L I$ & $00^{\circ} 0$ & Ito 0 & $10^{\circ} \mathrm{Z}$ & $8 L^{\circ} I$ & $t L L^{\circ} Z$ & $\angle Z^{\prime} Z$ & $\nabla 0^{\circ} L t$ & SSLL & $1 L \circ 88$ & $\varepsilon t^{\circ} \varepsilon t$ & TOD \\
\hline \multicolumn{13}{|c|}{ Z66I } \\
\hline วза & $\Lambda \mathrm{ON}$ & $\mathbf{I D O}$ & d'AS & $\mathrm{D} \cap \mathrm{V}$ & Tnf & Nnf & $X \mathbf{V W}$ & ydV & YVW & ชงม & NVP & 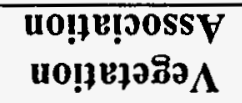 \\
\hline
\end{tabular}




\section{APPENDIX B}

Percent cover of vegetation at Yucca Mountain, Nevada, from 1989 through 1994. Cover is listed by Ecological Study Plot (Appendix B-1) and by species (Appendix B-2) for each vegetation association. 


\section{-APPENDIX B1}

Percent cover on each Ecological Study Plot (ESP) from 1989 through 1993 at Yucca Mountain,

Nevada. Ecological Study Plots with ND (no data) were not censused until 1990 or 1991.

\begin{tabular}{|c|c|r|r|r|r|r|}
\hline ESP & 1989 & \multicolumn{1}{|c|}{1990} & 1991 & 1992 & 1993 & 1994 \\
\hline COL1C & 22.63 & 14.25 & 12.37 & 33.62 & 26.25 & 19.50 \\
\hline COL2C & 22.87 & 14.12 & 9.75 & 24.62 & 22.37 & 12.00 \\
\hline COL3C & 20.62 & 15.00 & 10.12 & 26.87 & 23.75 & 18.00 \\
\hline COL4C & 22.50 & 13.12 & 10.37 & 32.62 & 24.75 & 17.87 \\
\hline COL5C & ND & 26.75 & 25.12 & 22.75 & 32.50 & 32.12 \\
\hline COL6C & ND & 25.12 & 21.37 & 25.62 & 35.73 & 28.87 \\
\hline COL1T & 24.40 & 16.51 & 10.80 & 25.31 & 21.20 & 18.10 \\
\hline COL2T & 19.30 & 16.50 & 10.30 & 23.79 & 23.00 & 14.90 \\
\hline COL3T & 23.90 & 14.80 & 12.62 & 24.60 & 23.10 & 14.80 \\
\hline COL4T & ND & 17.80 & 21.50 & 21.20 & 28.40 & 21.32 \\
\hline COL5T & ND & 20.00 & 25.61 & 36.10 & 38.80 & 30.10 \\
\hline COL6T & 19.90 & 14.90 & 9.10 & 21.60 & 21.10 & 14.60 \\
\hline LA2C & 20.00 & 12.37 & 12.50 & 17.87 & 21.12 & 19.50 \\
\hline LA3C & 20.12 & 15.25 & 11.25 & 18.39 & 22.28 & 21.57 \\
\hline LA4C & 21.25 & 14.62 & 14.50 & 17.15 & 19.12 & 24.30 \\
\hline LA5C & 14.87 & 15.00 & 8.75 & 23.00 & 15.00 & 15.00 \\
\hline LA6C & 15.50 & 16.25 & 10.63 & 18.75 & 23.28 & 12.54 \\
\hline LA7C & 20.12 & 18.75 & 13.87 & 22.38 & 15.75 & 17.75 \\
\hline LA1T & 11.40 & 12.70 & 8.12 & 15.40 & 16.17 & 14.32 \\
\hline LA2T & 18.90 & 15.80 & 7.50 & 17.80 & 16.90 & 15.71 \\
\hline LA3T & 13.80 & 10.50 & 8.31 & 23.48 & 23.80 & 18.10 \\
\hline LA4T & 16.90 & 13.90 & 6.90 & 21.22 & 20.00 & 16.20 \\
\hline LA5T & 15.20 & 13.60 & 9.89 & 20.50 & 20.39 & 17.80 \\
\hline LA7T & 15.70 & 16.00 & 13.68 & 24.70 & 24.28 & 19.94 \\
\hline LG1C & ND & 13.12 & 15.50 & 30.47 & 30.87 & 12.20 \\
\hline LG2C & ND & 15.62 & 16.87 & 35.30 & 31.87 & 17.73 \\
\hline LG3C & 23.81 & 17.37 & 20.37 & 35.75 & 36.75 & 20.71 \\
\hline LG4C & 16.62 & 15.25 & 14.37 & 32.12 & 30.37 & 16.00 \\
\hline LG5C & ND & 13.87 & 17.62 & 26.78 & 23.15 & 17.12 \\
\hline LG6C & ND & 17.37 & 13.37 & 22.23 & 25.12 & 13.17 \\
\hline LG2T & ND & 20.10 & 22.80 & 31.16 & 35.38 & 21.21 \\
\hline LG3T & 20.80 & 14.30 & 20.40 & 32.74 & 31.00 & 20.00 \\
\hline LG4T & 18.58 & 16.60 & 15.00 & 34.42 & 28.51 & 19.60 \\
\hline LG5T & ND & 13.90 & 11.89 & 31.51 & 24.09 & 18.90 \\
\hline & & & & & & \\
\hline
\end{tabular}


Appendix B1 (continued)

\begin{tabular}{|c|c|r|r|r|r|r|}
\hline ESP & \multicolumn{1}{|c|}{1989} & \multicolumn{1}{c|}{1990} & \multicolumn{1}{c|}{1991} & 1992 & 1993 & 1994 \\
\hline LG6T & 22.03 & 14.60 & 16.80 & 33.30 & 32.72 & 15.60 \\
\hline LG7T & ND & 16.00 & 15.00 & 31.33 & 29.46 & 20.60 \\
\hline LLG3C & 20.87 & 16.75 & 16.50 & 32.00 & 31.72 & 20.12 \\
\hline LLG4C & 18.12 & 12.62 & 15.50 & 35.00 & 30.37 & 17.86 \\
\hline LLG5C & 18.00 & 12.87 & 19.94 & 34.50 & 32.54 & 13.12 \\
\hline LLG7C & ND & 13.50 & 17.25 & 36.50 & 28.87 & 15.62 \\
\hline LLG8C & ND & 14.75 & 17.12 & 42.75 & 39.25 & 26.50 \\
\hline LLG9C & ND & 14.25 & 17.39 & 36.84 & 25.37 & 17.62 \\
\hline LLG1T & 20.30 & 13.30 & 19.30 & 43.12 & 35.53 & 31.50 \\
\hline LLG2T & 10.70 & 8.40 & 16.90 & 45.44 & 37.50 & 23.80 \\
\hline LLG4T & 19.50 & 17.40 & 17.90 & 35.70 & 27.80 & 17.80 \\
\hline LLG5T & 15.20 & 12.60 & 18.00 & 35.92 & 35.57 & 27.20 \\
\hline LLG6T & 19.70 & 12.70 & 14.67 & 27.50 & 24.10 & 20.10 \\
\hline LLG7T & ND & ND & 12.70 & 29.90 & 26.20 & 17.11 \\
\hline
\end{tabular}




\section{APPENDIX B2}

Average percent plant cover by species for the Coleogyne (COL), Larrea-Ambrosia (LA), Lycium-Grayia (LG), Larrea-Lycium-Grayia (LLG) vegetation associations at Yucca Mountain, Nevada, from 1989 through 1994 . Species with less than $0.1 \%$ cover are indicated with a "T"; species not present are indicated with a "-.".

\begin{tabular}{|c|c|c|c|c|}
\hline Species & $\mathrm{COL}$ & LA & LG & LLG \\
\hline Acamptopappus shockleyi & $\mathrm{T}$ & 1.41 & $\mathrm{~T}$ & $T$ \\
\hline Ambrosia dumosa & 1.41 & 5.90 & 0.64 & 1.27 \\
\hline Amsinckia tessellata & 0.66 & $\mathrm{~T}$ & 0.27 & 2.40 \\
\hline Aristida purpurea & - & - & $\mathrm{T}$ & - \\
\hline Artemisia spinescens & $\mathrm{T}$ & - & $\mathrm{T}$ & $\mathrm{T}$ \\
\hline Artemisia tridentata & - & - & 0.12 & - \\
\hline Astragalus acutirostris & $\mathrm{T}$ & $\mathrm{T}$ & $\mathrm{T}$ & $T$ \\
\hline Astragalus layneae & $\mathrm{T}$ & $\mathrm{T}$ & - & $\mathrm{T}$ \\
\hline Atriplex canescens & $\therefore \mathrm{T}$ & - & 0.14 & $\mathrm{~T}$ \\
\hline Atriplex confertifolia & 0.36 & 0.20 & 0.70 & $\mathrm{~T}$ \\
\hline Atriplex polycarpa & - & - & $\mathrm{T}$ & - \\
\hline Brickellia microphylla & - & - & $\mathrm{T}$ & - \\
\hline Bromus rubens & 4.33 & 0.45 & 5.09 & 7.49 \\
\hline Bromus tectorum & $\mathrm{T}$ & - & $\mathrm{T}$ & - \\
\hline Calochortus flexuosus & $\mathrm{T}$ & - & $\mathrm{T}$ & $\mathrm{T}$ \\
\hline Camissonia brevipes & $\mathrm{T}$ & - & $\mathrm{T}$ & $\mathrm{T}$ \\
\hline Castilleja angustifolia & - & $\mathrm{T}$ & $\mathrm{T}$ & - \\
\hline Centrostegia thurberi & $\mathrm{T}$ & $\mathrm{T}$ & $\mathrm{T}$ & $\mathrm{T}$ \\
\hline Chaenactis carphoclinia & $\mathrm{T}$ & - & - & - \\
\hline Chaenactis fremontii & $\mathrm{T}$ & - & $=$ & - \\
\hline Chaenactis macrantha & - & $\mathrm{T}$ & - & - \\
\hline Chàenactis stevioides & 0.24 & 0.93 & $T$ & 0.18 \\
\hline Chamaesyce albomarginata & $\mathrm{T}$ & $\ldots$ & $\mathrm{T}$ & $\mathrm{T}$ \\
\hline Chorizanthe brevicornu & 0.17 & $\mathrm{~T}$ & $\mathrm{~T}$ & $\mathrm{~T}$ \\
\hline Chorizanthe rigida & $\mathrm{T}$ & $\mathrm{T}$ & - & $\mathrm{T}$ \\
\hline Chrysothamnus nauseosus & $\mathrm{T}$ & - & $\mathrm{T}$ & - \\
\hline Chrysothamnus teretifolius & 0.23 & - & 0.45 & - \\
\hline Chrysothamnus viscidiflorus & $T$ & - & 0.20 & $\mathrm{~T}$ \\
\hline Cirsium neomexicanum & - & - & $\mathrm{T}$ & - \\
\hline Coleogyne ramosissima & 5.57 & 0.30 & $\mathrm{~T}$ & 0.14 \\
\hline Cryptantha circumscissa & $T$ & $\mathrm{~T}$ & $\mathrm{~T}$ & $\mathrm{~T}$ \\
\hline Cryptantha micrantha & $\mathrm{T}$ & $\mathrm{T}$ & $\mathrm{T}$ & $\mathrm{T}$ \\
\hline
\end{tabular}


Appendix B2 (continued)

\begin{tabular}{|c|c|c|c|c|}
\hline Species & $\mathrm{COL}$ & $\mathbf{L A}$ & LG & LLG \\
\hline Cryptantha nevadensis & 0.17 & $\mathrm{~T}$ & $\mathrm{~T}$ & $T$ \\
\hline Cryptantha pterocarya & $\mathrm{T}$ & 0.16 & 0.14 & 0.26 \\
\hline Cuscuta denticulata & - & $\mathrm{T}$ & - & - \\
\hline Dalea mollissima & - & - & - & $\mathrm{T}$ \\
\hline Delphinium parishii & $\mathrm{T}$ & $\mathrm{T}$ & $T$ & - \\
\hline Descurainia pinnata & 0.20 & 0.12 & $\mathrm{~T}$ & 0.40 \\
\hline Dichelostemma congestum & $\mathrm{T}$ & $\mathrm{T}$ & - & $\mathrm{T}$ \\
\hline Echinocactus polycephalus & $\mathrm{T}$ & - & $T$ & $\ldots$ \\
\hline Echinocereus engelmannii & $T$ & - & - & - \\
\hline Elymus elymoides & $\mathrm{T}$ & - & $\mathrm{T}$ & - \\
\hline Elymus multisetus & - & - & $\mathrm{T}$ & $\mathrm{T}$ \\
\hline Encelia virginensis & 0.26 & $\mathrm{~T}$ & 0.11 & $\mathrm{~T}$ \\
\hline Ephedrainevadensis & 1.73 & 0.57 & 2.20 & 2.25 \\
\hline Ephedra viridis. & 0.11 & - & 0.30 & $\mathrm{~T}$ \\
\hline Eriastrum eremicum & $\mathrm{T}$ & $\mathrm{T}$ & $\mathrm{T}$ & $T$ \\
\hline Eriastrum sparsiflorum & $\mathrm{T}$ & - & $\mathrm{T}$ & - \\
\hline Ericameria cooperi & 0.16 & 0.19 & 1.16 & 0.32 \\
\hline Ericameria linearifolia & $\mathrm{T}$ & - & 0.14 & - \\
\hline Eriogonum deflexum & $\mathrm{T}$ & $\mathrm{T}$ & $T$ & $\mathrm{~T}$ \\
\hline Eriogonum fasciculatum & 0.16 & $\mathrm{~T}$ & 1.65 & 0.11 \\
\hline Eriogonum inflatum & $\mathrm{T}$ & $T$ & $\mathrm{~T}$ & 0.19 \\
\hline Eriogonum maculatum & $\mathrm{T}$ & $\mathrm{T}$ & $\mathrm{T}$ & $\mathrm{T}$ \\
\hline Eriogonum microthecum & $\mathrm{T}$ & - & $\mathrm{T}$ & - \\
\hline Eriogonum nidularium & 0.11 & $T$ & $\mathrm{~T}$ & $\mathrm{~T}$ \\
\hline Erioneuron pulchellum & - & $\mathrm{T}$ & $\mathrm{T}$ & $\mathrm{T}$ \\
\hline Eriophyllum pringlei & $T$ & $\mathrm{~T}$ & - & $\mathrm{T}$ \\
\hline Erodium cicutarium & 0.20 & - & $\mathrm{T}$ & $\mathrm{T}$ \\
\hline Eschscholzia minutiflora & - & $\mathrm{T}$ & $\mathrm{T}$ & $\mathrm{T}$ \\
\hline Grayia spinosa & 0.44 & 0.10 & 1.64 & 0.28 \\
\hline Gutierrezia sarothrae & $\mathrm{T}$ & - & 0.35 & -1 \\
\hline Hilaria jamesii & $\mathrm{T}$ & - & 0.53 & $-\quad$ \\
\hline Hymenoclea salsola & 0.13 & $T$ & 0.75 & 0.63 \\
\hline Krameria erecta & 0.84 & 0.54 & $\mathrm{~T}$ & 1.30 \\
\hline Krascheninnikovia lanata & $T$ & 0.13 & 0.35 & 0.11 \\
\hline Larrea tridentata & 0.28 & 1.52 & 0.11 & 3.07 \\
\hline Lepidium fremontii & - & - & $\mathrm{T}$ & $\mathrm{T}$ \\
\hline Lepidium lasiocarpum & $\mathrm{T}$ & $\mathrm{T}$ & $\mathrm{T}$ & 0.11 \\
\hline
\end{tabular}


Appendix B2 (continued)

\begin{tabular}{|l|c|c|c|c|}
\hline \multicolumn{1}{|c|}{ Species } & COL & LA & LG & LLG \\
\hline Loeseliastrum schottii & $\mathrm{T}$ & $\mathrm{T}$ & - & - \\
\hline Lomatium nevadense & $\mathrm{T}$ & - & - & - \\
\hline Lotus humistratus & 0.49 & - & $\mathrm{T}$ & 0.23 \\
\hline Lupinus concinnus & $\mathrm{T}$ & $\mathrm{T}$ & - & $\mathrm{T}$ \\
\hline Lupinus flavoculatus & $\mathrm{T}$ & $\mathrm{T}$ & $\mathrm{T}$ & $\mathrm{T}$ \\
\hline Lycium andersonii & 0.43 & 0.20 & 1.52 & 0.65 \\
\hline Lycium pallidum & 0.38 & 0.82 & 0.15 & 0.23 \\
\hline Malacothrix glabrata & $\mathrm{T}$ & $\mathrm{T}$ & $\mathrm{T}$ & $\mathrm{T}$ \\
\hline Menodora spinescens & 0.29 & 1.72 & 0.25 & 0.33 \\
\hline Mentzelia obscura & 0.15 & $\mathrm{~T}$ & $\mathrm{~T}$ & 0.41 \\
\hline Mirabilis bigelovii & - & - & $\mathrm{T}$ & $\mathrm{T}$ \\
\hline Monoptilon bellidiforme & - & $\mathrm{T}$ & - & $\mathrm{T}$ \\
\hline Muhlenbergia porteri & - & - & $\mathrm{T}$ & - \\
\hline Nama demissum & $\mathrm{T}$ & $\mathrm{T}$ & - & - \\
\hline Opuntia basilaris & $\mathrm{T}$ & - & $\mathrm{T}$ & $\mathrm{T}$ \\
\hline Opuntia echinocarpa & - & $\mathrm{T}$ & - & $\mathrm{T}$ \\
\hline Oryzopsis hymenoides & $\mathrm{T}$ & 0.15 & $\mathrm{~T}$ & $\mathrm{~T}$ \\
\hline Oxytheca perfoliata & 0.15 & $\mathrm{~T}$ & $\mathrm{~T}$ & $\mathrm{~T}$ \\
\hline Pectocarya platycarpa & 0.27 & 0.26 & $\mathrm{~T}$ & 0.10 \\
\hline Pectocarya setosa & 0.20 & $\mathrm{~T}$ & $\mathrm{~T}$ & $\mathrm{~T}$ \\
\hline Phacelia crenulata & $\mathrm{T}$ & - & $\mathrm{T}$ & - \\
\hline Phacelia fremontii & $\mathrm{T}$ & $\mathrm{T}$ & $\mathrm{T}$ & $\mathrm{T}$ \\
\hline Phacelia vallis-mortae & $\mathrm{T}$ & - & - & - \\
\hline Phlox stansburyi & - & - & $\mathrm{T}$ & - \\
\hline Psorothamrius fremontii & - & $\mathrm{T}$ & $\mathrm{T}$ & $\mathrm{T}$ \\
\hline Rafinesquia neomexicana & $\mathrm{T}$ & $\mathrm{T}$ & $\mathrm{T}$ & $\mathrm{T}$ \\
\hline Salazaria mexicana & $\mathrm{T}$ & $\mathrm{T}$ & 0.32 & 0.30 \\
\hline Salsola kali & $\mathrm{T}$ & $\mathrm{T}$ & $\mathrm{T}$ & $\mathrm{T}$ \\
\hline Schismus arabicus & $\mathrm{T}$ & $\mathrm{T}$ & - & $\mathrm{T}$ \\
\hline Sclerocactus polyancistrus & $\mathrm{T}$ & 0.13 & $\mathrm{~T}$ & $\mathrm{~T}$ \\
\hline Sisymbrium altissimum & $\mathrm{T}$ & - & 0.13 & $\mathrm{~T}$ \\
\hline Sphaeralcea ambigua & $\mathrm{T}$ & $\mathrm{T}$ & $\mathrm{T}$ & $\mathrm{T}$ \\
\hline Stephanomeria parryi & $\mathrm{T}$ & $\mathrm{T}$ & $\mathrm{T}$ \\
\hline Stephanomeria pauciflora & $\mathrm{T}$ & $\mathrm{T}$ & $\mathrm{T}$ & - \\
\hline Stipa speciosa & $\mathrm{T}$ & $\mathrm{T}$ \\
\hline Syntrichopappus fremontii & $\mathrm{T}$ & $\mathrm{T}$ \\
\hline Tetradymia axillaris & & & \\
\hline & & -43 & - \\
\hline
\end{tabular}


Appendix B2 (continued)

\begin{tabular}{|l|c|c|c|c|}
\hline \multicolumn{1}{|c|}{ Species } & COL & LA & LG & LLG \\
\hline Tetradymia glabrata & - & - & $\mathrm{T}$ & $\mathrm{T}$ \\
\hline Vulpia octoflora & 0.25 & 0.45 & $\mathrm{~T}$ & $\mathrm{~T}$ \\
\hline Xylorhiza tortifolia & $\mathrm{T}$ & $\mathrm{T}$ & - & $\mathrm{T}$ \\
\hline Yucca brevifolia & $\mathrm{T}$ & - & - & - \\
\hline
\end{tabular}




\section{APPENDIX C}

Plant density at Yucca Mountain, Nevada, from 1991 to 1993. Densities are listed by vegetation association (Appendix C1), and by species within association (Appendices C2 through C5). 


\section{ÁPPENDIX C1}

Density (plants $100 \mathrm{~m}^{-2}$ ) in the Coleogyne (COL), Larrea-Ambrosia (LA), Lycium-Grayia (LG), and Larrea-Lycium-Grayia (LLG) vegetation associations at Yucca Mountain, Nevada, averaged over 12 Ecological Study Plots. In the Coleogyne, Larrea-Ambrosia, and Lycium-Grayia, averages are for two years; in the Larrea-Lycium-Grayia averages are for three years. Trace observations (density < 0.1 ) are indicated by "T"; species not present are indicated with a "-.." .

\begin{tabular}{|c|c|c|c|c|}
\hline \begin{tabular}{|r} 
Species \\
\end{tabular} & COL & LA & LG & LLG \\
\hline Acamptopappus shockleyi. & - & 19.8 & 0.2 & 0.3 \\
\hline Ambrosia dumosa & 17.3 & 61.5 & 7.9 & 12.9 \\
\hline Aristida purpurea & - & $-\quad 1$ & 0.5 & $\mathrm{~T}$ \\
\hline Artemisia spinescens & $\mathrm{T}$ & - & 0.2 & - \\
\hline Artemisia tridentata & $\mathrm{T}$ & - & 0.2 & - \\
\hline Astragalus layneae & $\mathrm{T}$ & $\mathrm{T}$ & - & $\mathrm{T}$ \\
\hline Atriplex canescens & 0.1 & $\mathrm{~T}$ & 0.4 & $\mathrm{~T}$ \\
\hline Atriplex confertifolia & 3.5 & 1.6 & 5.1 & 0.2 \\
\hline Brickellia microphylla & - & - & 0.3 & - \\
\hline Calochortus flexuosus & - & $\mathrm{T}$ & $T$ & - \\
\hline Castilleja angustifolia & - & - & $\mathrm{T}$ & - \\
\hline Chamaesyce albomarginata & .0 .1 & - & $\mathrm{T}$ & $\mathrm{T}$ \\
\hline Chrysothamnus nauseosus & $\mathrm{T}$ & - & 0.3 & - \\
\hline Chrysothamnus teretifolius & 1.2 & - & 3.2 & - \\
\hline Chrysothamnus viscidiflorus & 0.2 & - & 1.6 & - \\
\hline Coleogyne ramosissima & 18.6 & 1.1 & $\mathrm{~T}$ & 0.5 \\
\hline Delphinium parishii & \begin{tabular}{l|l}
$\mathrm{T}$ \\
\end{tabular} & - & $\mathrm{T}$ & - \\
\hline Echinocactus polycephalus & $\mathrm{T}$ & $\mathrm{T}$ & $\mathrm{T}$ & $T$ \\
\hline Echinocereus engelmannii & $\mathrm{T}$ & - & 0.2 & $\mathrm{~T}$ \\
\hline Elymus elymoides & - & - & $T . \quad$ & - \\
\hline Encelia virginensis & 1.7 & 0.2 & 0.9 & 0.8 \\
\hline Ephedra nevadensis & 6.9 & 3.8 & 14.4 & 8.9 \\
\hline Ephedra viridis & 0.3 & $-\quad 1$ & 1.0 & $\mathrm{~T}$ \\
\hline Ericameria cooperi & 0.7 & 1.2 & 10.8 & 2.1 \\
\hline Ericameria linearifolia & $\mathrm{T}$ & - & 1.0 & - \\
\hline Eriogonum fasciculatum & 0.6 & $T$ & 10.9 & 0.8 \\
\hline Eriogonum inflatum & $T$ & $\mathrm{~T}$ & 0.3 & $\mathrm{~T}$ \\
\hline Eriogonium microthecum & - & $-\quad 1$ & 0.7 & - \\
\hline Erioneuron pulchellum & 0.3 & 0.3 & 12.2 & 2.7 \\
\hline Grayia spinosa & 1.2 & 1.0 & 8.0 & 0.6 \\
\hline Gutierrezia sarothrae & $\mathrm{T}$ & $-\quad$ & 3.9 & $T$ \\
\hline Hilaria jamesii & 2.1 & - & 7.7 & - \\
\hline
\end{tabular}


APPENDIX C1 (continued)

\begin{tabular}{|c|c|c|c|c|}
\hline Species. & COL & LA & LG & LLG \\
\hline Hymenoclea salsola & 0.8 & $\mathrm{~T}$ & 5.4 & 2.6 \\
\hline Juniperous osteosperma & -1 & - & $\mathrm{T}, \mathrm{I}$ & - \\
\hline Krameria erecta & 8.8 & 5.4 & $\mathrm{~T}$ & 11.7 \\
\hline Krascheninnikovia lanata & 0.1 & 3.6 & 4.9 & 1.2 \\
\hline Larrea tridentata & 0.7 & 5.2 & 0.2 & 5.8 \\
\hline Lepidium fremontii & - & - & $\mathrm{T}$ & $\mathrm{T}$ \\
\hline Leptodactylon pungens & $=$ & - & 0.1 & - \\
\hline Lycium andersonii & 2.6 & 0.8 & 7.1 & 3.9 \\
\hline Lycium pallidum & 2.3 & 4.8 & 0.5 & 1.0 \\
\hline Menodora spinescens & 1.2 & 14.8 & 1.5 & 2.5 \\
\hline Mirabilis bigelovii & - & $\mathrm{T}$ & $\mathrm{T}$ & 0.2 \\
\hline Muhlenbergia porteri & - & - & 0.1 & - \\
\hline Opuntia basilaris & $\mathrm{T}$ & $T$ & 0.4 & $\mathrm{~T}$ \\
\hline Opuntia echinocarpa & $\mathrm{T}$ & $\mathrm{T}$ & - & $\mathrm{T}$ \\
\hline Oryzopsis hymenoides & - & 0.9 & 0.1 & 0.1 \\
\hline Psorothamnus fremontii & $-\quad 1$ & 0.2 & - & $T$ \\
\hline Salazaria mexicana & 0.4 & $\mathrm{~T}$ & 0.7 & 1.2 \\
\hline Sclerocactus polyancistrus & $-\quad 1$ & - & $\mathrm{T}$ & - \\
\hline Sphaeralcea ambigua & $T$ & $\mathrm{~T}$ & 12.9 & 0.2 \\
\hline Sporobolus cryptandrus & $\mathrm{T}$ & - & 0.3 & - \\
\hline Stephanomeria pauciflora & $\mathrm{T}$ & $\mathrm{T}$ & 0.3 & 0.3 \\
\hline Stipa speciosa & 0.4 & 0.1 & 12.3 & 1.1 \\
\hline Tetradymia axillaris & $\mathrm{T}$ & $\mathrm{T}$ & 0.2 & $T$ \\
\hline Tetradymia glabrata & - & - & $\mathrm{T}$ & - \\
\hline Xylorhiza tortifolia & $\quad 0.5$ & 0.5 & 0.1 & $\mathrm{~T}$ \\
\hline Yucca brevifolia & $\mathrm{T}$ & - & - & - \\
\hline
\end{tabular}




\section{APPENDIX C2}

Density (plants $100 \mathrm{~m}^{-2}$ ) of all species found in Ecological Study Plots (ESPs) of the Coleogyne vegetation association at Yucca Mountain, Nevada. Densities are averages from 1991 to 1992. Trace observations (density <0.1) are indicated by " $T$ "; zeros are indicated by "-."

\begin{tabular}{|c|c|c|c|c|c|c|c|c|c|c|c|c|}
\hline Species & COL1C & COL1T & COL2C & COL2T & COL3C & COL3T & COL4C & COL4T & COL5C & COL5T & COL6C & COL6T \\
\hline Ambrosia dumosa & 19.0 & 26.3 & 22.5 & 27.4 & 21.6 & 26.3 & 19.8 & - & - & 0.6 & - & 44.4 \\
\hline Artemisia spinescens & - & - & - & - & - & - & - & - & - & 0.5 & - & - \\
\hline Artemisia tridentata & - & - & - & - & - & - & - & - & 0.1 & - & - & - \\
\hline Astragalus layneae & - & - & - & $T$ & - & - & - & - & - & - & - & - \\
\hline Atriplex canescens & - & 0.3 & - & - & - & - & - & 0.4 & - & 0.8 & 0.1 & - \\
\hline Atriplex confertifolia & - & 5.0 & 6.6 & 4.5 & 1.9 & 9.1 & 5.5 & - & - & 3.7 & 0.1 & 5.7 \\
\hline Chamaesyce albomarginata & - & - & $-\quad$ & - & - & - & - & - & $\mathrm{T}$ & - & 1.5 & - \\
\hline Chrysothamnus nauseosus & - & - & - & - & - & - & - & - & 0.1 & 0.2 & - & - \\
\hline Chrysothamnus teretifolizis & - & - & $\approx$ & 0.1 & - & - & - & 1.4 & 4.6 & 6.4 & 2.0 & - \\
\hline Chrysothamnus viscidiflorus & $=$ & - & - & - & - & - & - & - & 0.2 & 2.1 & 0.5 & - \\
\hline Coleogyne ramosissima & 7.4 & 5.8 & 9.2 & 9.5 & 8.6 & 8.3 & 7.4 & 25.8 & 49.1 & 27.3 & 57.2 & 7.9 \\
\hline Delphinium parishii & - & - & - & - & $\mathrm{T}$ & - & - & - & - & - & - & 0.2 \\
\hline Echinocactus polycephalus & $=$ & 0.1 & - & - & - & - & - & - & - & - & $\mathrm{T}$ & - \\
\hline Echinocereus engelmannii & - & $=$ & 0.1 & - & - & - & - & 0.1 & 0.4 & - & - & - \\
\hline Encelia virginensis & 0.4 & 4.4 & 2.4 & 3.5 & 4.6 & 2.5 & 0.4 & 0.1 & - & 0.2 & - & 2.1 \\
\hline Ephedra nevadensis & 4.8 & 8.1 & 7.3 & 9.7 & 7.1 & 6.5 & 4.1 & 9.3 & 3.8 & 8.7 & 6.8 & 7.3 \\
\hline Ephedra viridis & - & - & 0.1 & - & - & - & - & - & 1.3 & 0.1 & 1.5 & - \\
\hline Ericameria cooperi & 0.2 & 0.1 & 0.1 & 2.6 & 0.1 & 0.1 & 0.1 & 0.5 & 0.5 & 4.2 & - & 0.3 \\
\hline Ericameria linearifolia & - & - & - & - & - & - & - & - & - & 0.3 & $=$ & - \\
\hline Eriogonum fasciculatum & 0.5 & $\mathrm{~T}$ & 0.5 & 1.6 & 1.5 & 1.0 & 0.1 & 0.1 & - & 1.4 & - & 0.6 \\
\hline Eriogonum inlatum & $=$ & $=$ & - & - & - & 0.1 & - & - & - & $-\quad$. & - & - \\
\hline Erioneuron pulchellum & - & - & - & - & 0.3 & 3.6 & - & - & - & - & $=$ & - \\
\hline Grayia spinosa & 1.4 & 0.3 & 0.4 & 0.3 & 0.4 & 0.2 & 0.3 & 0.9 & 3.6 & 4.8 & 1.6 & 0.4 \\
\hline Gutierrezia sarothrae & - & - & - & - & - & - & - & - & - & - & 0.1 & - \\
\hline Hilaria jamesii & - & $\therefore$ & $=$ & - & $=$ & - & - & - & - & 24.8 & $\therefore$ & $=$ \\
\hline
\end{tabular}


APPENDIX C2 (continued)

\begin{tabular}{|c|c|c|c|c|c|c|c|c|c|c|c|c|}
\hline Species & COLIC & COL1T & $\mathrm{COL2C}$ & COL2T & COL3C & COL3T & COLAC & COL4T & COL5C & COL5T & COL6C & COL6T \\
\hline Hymenoclea salsola & - & 0.1 & - & - & 0.1 & - & - & 8.7 & $\therefore$ & 0.2 & - & - \\
\hline Krameria erecta & 9.9 & 17.6 & 12.6 & 13.3 & 11.8 & 11.2 & 19.2 & - & - & - & - & 10.4 \\
\hline Krascheninnikovia lanata & 0.2 & - & 0.1 & 0.3 & 0.4 & 0.1 & 0.3 & - & - & 0.4 & - & - \\
\hline Larrea tridentata & 1.1 & 1.3 & 0.6 & 0.8 & 0.5 & 0.4 & 2.4 & - & - & - & - & 0.9 \\
\hline Lycium andersonii & 2.5 & 2.6 & 2.1 & 3.7 & 3.4 & 1.5 & 2.3 & 1.9 & 2.2 & 5.1 & 1.5 & 2.0 \\
\hline Lycium pallidum & - & 5.1 & - & 3.6 & 4.6 & 2.8 & 5.2 & - & $\therefore$ & - & - & 5.8 \\
\hline Menodora spinescens & 0.4 & 1.6 & 3.8 & 0.7 & 2.5 & 4.9 & 0.6 & - & - & - & - & 0.6 \\
\hline Opuntia basilaris & 0.3 & $-\quad "$ & - & - & - & - & - & 0.1 & 0.4 & 0.1 & - & - \\
\hline Opuntia echinocarpa & 0.1 & - & - & 0.1 & 0.1 & - & - & - & - & - & - & - \\
\hline Salazaria mexicana & 0.4 & 0.2 & 1.6 & 1.2 & 1.0 & 0.1 & - & - & - & - & - & 0.3 \\
\hline Sphaeralcea ambigua & - & - & - & - & - & - & - & - & 0.1 & 0.4 & - & $-\quad \cdot$ \\
\hline Sporobolus cryplandrus & - & - & - & - & - & - & - & - & - & 0.2 & - & - \\
\hline Stephanomeria pauciflora & - & $\mathrm{T}$ & - & 0.3 & 0.1 & 0.1 & - & - & - & - & - & - \\
\hline Stipa speciosa & 0.1 & 0.1 & 0.8 & 1.4 & 0.6 & 0.5 & 0.3 & 0.2 & - & 0.4 & 0.3 & 0.1 \\
\hline Tetradymia axillaris & - & $-\ldots$ & - & - & - & - & - & 0.3 & - & 0.1 & - & - \\
\hline Xylorhiza tortifolia & $=$ & 0.6 & 0.7 & 0.8 & 0.3 & 0.4 & 0.5 & - & -2 & - & - & 2.2 \\
\hline Yucca brevifolia & - & - & - & - & - & - & - & 0.1 & 0.4 & - & 0.3 & - \\
\hline
\end{tabular}


Density (plants $100 \mathrm{~m}^{-2}$ ) of all species found in Ecological Study Plots (ESPs) of the Larrea-Ambrosia vegetation association at Yucca Mountain, Nevada. Densities are averages from 1991 to 1992 . Trace observations (density < 0.1) are indicated by "T"; zeros are indicated by " - ".

\begin{tabular}{|c|c|c|c|c|c|c|c|c|c|c|c|c|}
\hline Species & LA1T & LA2C & LA2T & LA3C & LA3T & LA4C & LA4T & LA5C & LA5T & LA6C & LA7C & LA7T \\
\hline Acamplopappus shockleyi & 7.6 & 57.0 & 5.1 & 60.9 & 5.5 & 85.6 & 1.9 & 1.6 & 7.0 & - & 5.4 & - \\
\hline Ambrosia dumosa & 37.1 & 66.9 & 56.5 & 70.1 & 59.5 & 77.1 & 93.2 & 79.6 & 57.9 & 52.7 & 43.5 & 44.2 \\
\hline Astragalus layneae & - & - & - & - & - & - & - & - & $\ldots$ & 0.3 & - & $\mathrm{T}$ \\
\hline Atriplex canescens & - & $=$ & - & - & - & - & - & $=$ & - & - & 0.1 & - \\
\hline Atriplex confertifolia & - & - & - & - & - & $=$ & - & - & - & 9.8 & - & 9.8 \\
\hline Calochortus flexuosus & - & - & - & $=$ & - & - & - & - & - & - & - & 0.2 \\
\hline Coleogyne ramosissima & 10.1 & $=$ & $=$ & - & 0.2 & - & 2.4 & 0.1 & - & - & - & - \\
\hline Echinocactus polycephalus & - & - & - & - & - & - & - & - & - & - & - & 0.1 \\
\hline Encelia virginensis & - & $=$ & - & - & - & $=$ & - & - & - & 2.0 & - & - \\
\hline Ephedra nevadensis & 2.0 & - & 3.0 & - & 1.7 & - & 16.9 & 5.9 & 1.8 & 5.6 & 1.0 & 8.2 \\
\hline Ericameria cooperi & - & $=$ & - & - & 2.8 & - & - & - & 3.1 & - & 7.7 & 0.7 \\
\hline Eriogonum fasciculatum & - & - & - & - & - & - & - & - & - & 0.1 & - & 0.2 \\
\hline Eriogonum inflatum & - & - & $=$ & - & - & - & - & 0.1 & - & - & - & 0.1 \\
\hline Erioneuron pulchellum & - & 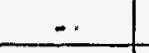 & - & - & - & - & - & 2.6 & - & 0.1 & - & 0.3 \\
\hline Grayia spinosa & 0.2 & - & - & - & 1.6 & - & 4.5 & - & 4.5 & - & - & 1.5 \\
\hline Hymenoclea salsola & - & - & 二 & - & - & $=$ & - & - & 0.2 & - & - & - \\
\hline Krameria erecta & 0.3 & - & 14.6 & 0.8 & 6.9 & - & 0.3 & 5.6 & 2.7 & 10.9 & 5.2 & 17.6 \\
\hline Krascheninnikovia lanata & 0.3 & 13.9 & 5.2 & 4.9 & 1.7 & 11.9 & 0.1 & 0.1 & 3.8 & - & 1.0 & 0.4 \\
\hline Larrea tridentata & 5.0 & 4.5 & 4.2 & 5.3 & 7.8 & 5.6 & 8.3 & 6.3 & 5.6 & 2.6 & 3.1 & 4.1 \\
\hline Lycium andersonii & - & - & - & - & 2.6 & - & 0.1 & - & 0.6 & 1.1 & 2.3 & 2.4 \\
\hline Lycium pallidum & 0.7 & - & 2.7 & - & 16.2 & - & 3.1 & 8.1 & 14.2 & 2.8 & 4.6 & 4.9 \\
\hline Menodora spinescens & 7.8 & 22.3 & 7.2 & 16.0 & 11.1 & 11.6 & - & 4.1 & 4.8 & 20.4 & 27.2 & 45.2 \\
\hline Mirabilis bigelovii & - & - & - & - & - & - & - & - & - & 0.5 & $\therefore \ldots$ & 0.4 \\
\hline Opuntia basilaris & - & - & $\therefore$ & - & - & - & 0.1 & - & - & - & $\therefore$ & $\therefore-\ldots$ \\
\hline Opuntia echinocarpa & - & - & 0.2 & - & 0.1 & 0.1 & - & - & 0.1 & - & & 0.1 \\
\hline Psorothamnus fremontii & - & - & $-\quad$ & - & - & - & - & - & - & -1.6 & $-\ldots$ & 0.9 \\
\hline Oryzopsis hymenoides & 1.2 & 2.8 & 4.6 & 0.8 & - & 0.5 & 0.3 & 0.4 & - & $=$ & -0.3 & $T$ \\
\hline
\end{tabular}




\begin{tabular}{|c|c|c|c|c|c|c|c|c|c|c|c|c|}
\hline Species & LA1T & LA2C & LA2T & LA3C & LA3T & LA4C & LA4T & LA5C & LA5T & LA6C & LA7C & LA7T \\
\hline Salazaria mexicana & - & - & $\cdot$ & - & - & - & - & 0.1 & - & 0.5 & 0.1 & - \\
\hline Sphaeralcea ambigua & 0.1 & 0.4 & - & - & - & - & - & 0.3 & - & - & - & 0.2 \\
\hline Stephanomeria pauciflora & - & - & - & - & $\therefore$ & - & - & 0.3 & - & 0.1 & - & 0.1 \\
\hline Stipa speciosa & - & - & - & - & - & $=$ & - & - & - & 0.6 & - & 0.6 \\
\hline Tetradymia axillaris & - & - & - & - & - & - & - & - & $-\div$ & $\therefore$ & 0.1 & - \\
\hline Xylorhiza tortifolia & - & - & $=$ & - & 2.1 & - & 0.1 & 0.4 & $\dot{0.9}$ & 2.6 & $-\ldots$ & 0.3 \\
\hline
\end{tabular}

2 
Density (plants $100 \mathrm{~m}^{-2}$ ) of all species found in Ecological Study Plots (ESPs) of the Lycium-Grayia vegetation association at Yucca Mountain, Nevada. Densities are averages from 1991 to 1992. Trace observations (density<0.1) are indicated by " $\mathrm{T}$ "; zeros are indicated by "-."

\begin{tabular}{|c|c|c|c|c|c|c|c|c|c|c|c|c|}
\hline Species & LG1C & LG2C & LG2T & LG3C & LG3T & LG4C & LG4T & LG5C & LGST & LG6T & LG7C & LG7T \\
\hline Acamptopappus shockleyi & 2.1 & - & 0.1 & - & - & - & - & - & 0.1 & - & - & - \\
\hline Ambrosia dumosa & 10.6 & 3.9 & 0.4 & 5.4 & 0.2 & 10.7 & 1.2 & 16.3 & 39.0 & 1.5 & 2.2 & 3.6 \\
\hline Aristida purpurea & 4.9 & 0.2 & - & - & - & - & - & - & $T$ & $=$ & 1.2 & - \\
\hline Artemisia spinescens & 0.8 & 0.5 & - & - & 0.2 & - & - & 0.8 & - & - & - & - \\
\hline Artemisia tridentata & $\therefore$ & & 2.1 & - & 0.1 & - & - & - & - & 0.2 & - & - \\
\hline Atriplex canescens & -0.3 & - & 0.7 & - & 0.8 & - & - & - & - & - & 1.4 & 1.4 \\
\hline Atriplex confertifolia & 8.9 & 4.5 & 1.8 & 5.9 & 0.1 & 10.6 & 1.0 & 8.5 & 9.6 & 3.3 & 3.8 & 3.2 \\
\hline Brickellia microphylla & - & - & 2.6 & $-\quad$ & - & - & - & 0.1 & - & - & 0.3 & 0.4 \\
\hline Calochortus flexuosus & - & $=$ & $=$ & - & - & - & - & 0.3 & $T$ & - & - & - \\
\hline Castilleja angustifolia & $=$ & - & $=$ & - & - & - & $=$ & - & - & $=$ & - & 0.2 \\
\hline Chamaesyce albomarginata & - & - & $T$ & - & - & - & 0.1 & - & - & - & - & 0.3 \\
\hline Chrysothamnus nauseosus & - & $=$ & 1.0 & - & 1.9 & - & - & 0.3 & 0.4 & - & - & 0.1 \\
\hline Chrysothammus teretifolius & - & 1.9 & 5.9 & 2.5 & 0.7 & 1.8 & 5.9 & 5.6 & 0.9 & 4.4 & 4.8 & 3.5 \\
\hline Chrysothamnus viscidiflorus & 2.4 & 2.4 & 2.5 & 1.4 & 4.8 & 2.1 & 0.8 & - & - & 1.5 & 0.1 & 0.7 \\
\hline Coleogyne ramosissima & - & 0.3 & 0.1 & - & - & - & - & - & - & $-\quad$ &. & - \\
\hline Delphinium parishii & - & - & $=$ & - & - & - & - & $\mathrm{T}$ & - & - & - & $\because$ \\
\hline Echinocactus polycephalus & 0.1 & $=$ & - & - & - & - & - & 0.1 & 0.6 & - & - & - \\
\hline Echinocereus engelmannii & 0.1 & 0.3 & $=$ & - & 0.1 & - & - & 0.8 & 0.4 & 0.3 & $=$ & - \\
\hline Elymus elymoides & - & $-\quad 1$ & 0.1 & - & 0.3 & - & - & - & - & - & - & - \\
\hline Encelia virginensis & 0.3 & - & 1.2 & - & - & - & - & 0.3 & 0.2 & - & 8.6 & 0.2 \\
\hline Ephedra nevadensis & 9.2 & $\therefore 10.1$ & 10.4 & 20.8 & 13.3 & 15.0 & 16.2 & 23.3 & 11.3 & 15.4 & 3.3 & 24.8 \\
\hline Ephedra viridis & 0.3 & 1.7 & 2.9 & - & 1.6 & - & 0.2 & - & - & 1.1 & 3.9 & 0.2 \\
\hline Ericameria cooperi & 12.3 & 12.9 & 6.5 & 20.0 & 11.7 & 14.8 & 10.2 & 4.8 & 3.1 & 23.6 & 1.5 & 8.1 \\
\hline Ericameria linearifolia & & $=$ & 1.6 & $\therefore$ & 8.4 & - & - & - & $-\quad$ & -1.6 & 0.1 & $\therefore \ldots$ \\
\hline Eriogonum fasciculatum & 2.6 & 6.01 & 10.7 & 3.8 & 24.6 & 7.4 & 5.8 & 26.1 & 3.1 & 7.8 & $26.2]$ & $\ldots .0$ \\
\hline
\end{tabular}




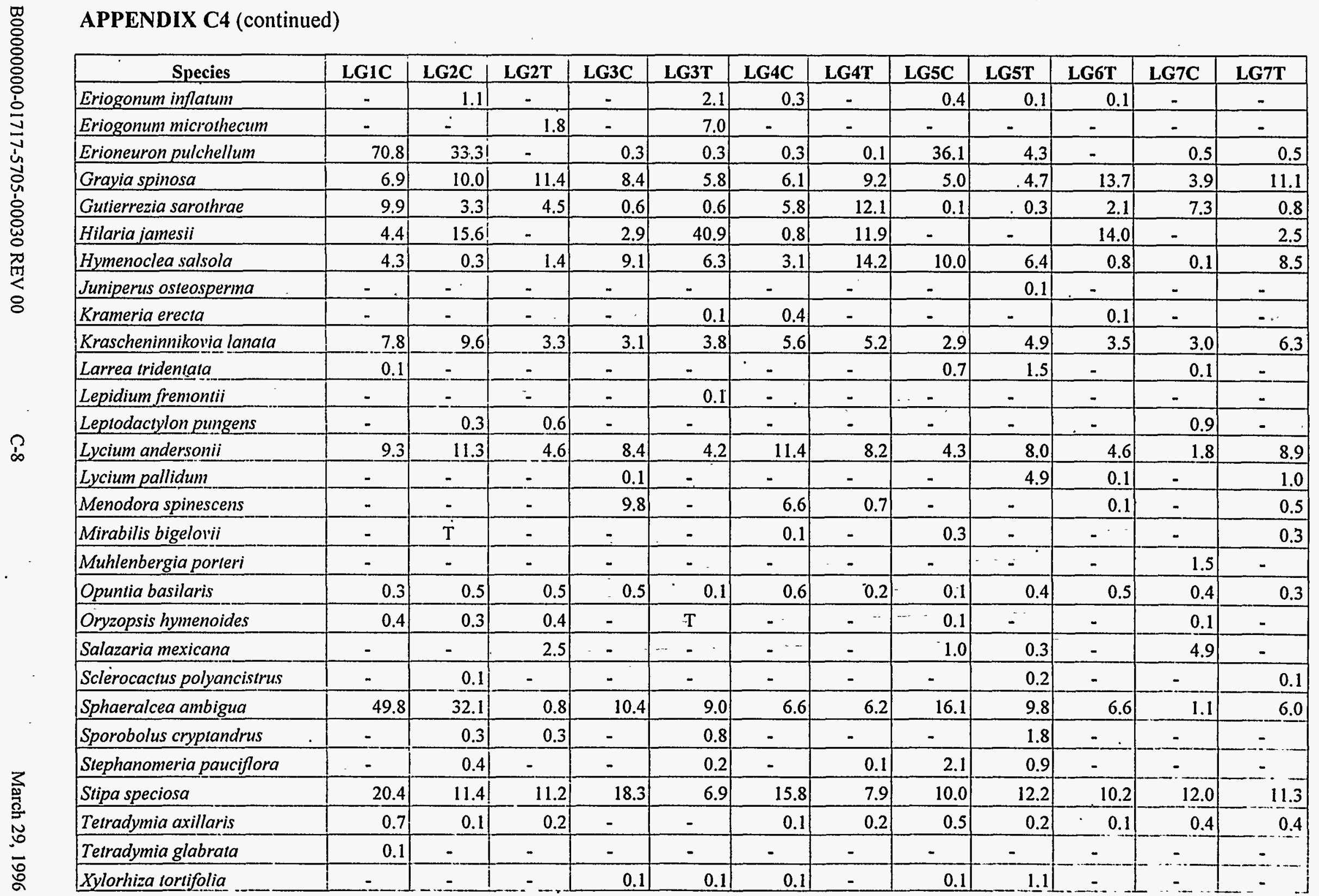




\section{APPENDIX C5}

Density (plants $100 \mathrm{~m}^{-2}$ ) of all species found in Ecological Study Plots (ESPs) of the Larrea-Lycium-Grayia vegetation association at Yucca Mountain, Nevada. Densities are averages from 1991 to 1992 . Trace observations (density< 0.1 ) are indicated by "T"; zeros are indicated by "-."

\begin{tabular}{|c|c|c|c|c|c|c|c|c|c|c|c|c|}
\hline Species & LLG1T & LLG2T & LLG3C & LLG4C & LLG4T & LLG5C & LLGST & LLG6T & LLG7C & LLG7T & LLG8C & LLG9C \\
\hline Acamplopappus shockleyi & 0.8 & 0.2 & 0.5 & 0.3 & - & - & 1.0 & - & $\because$ & - & 0.3 & 0.1 \\
\hline Ambrosia dumosa & 11.2 & 6.4 & 19.7 & 9.8 & 25.2 & 14.7 & 6.6 & 4.6 & 19.4 & 8.0 & 12.5 & 16.2 \\
\hline Aristida purpurea & - & - & - & - & - & - & - & - & 0.8 & - & - & - \\
\hline Astragalus layneae & - & -1 & - & - & - & 0.3 & - & - & $\mathrm{T}$ & 0.2 & - & - \\
\hline Atriplex canescens & - & 0.3 & - & - & - & - & - & - & $\mathrm{T}$ & - & 0.3 & 0.3 \\
\hline Atriplex conferifolia & - & $\therefore$ & - & 1.5 & - & - & - & - & 1.3 & - & - & 0.1 \\
\hline Chamaesyce albomarginata & - & - & - & - & - & - & - & $\mathrm{T}$ & - & - & - & - \\
\hline Coleogyne ramosissima & 0.1 & $\therefore$ & - & - & - & - & - & 1.2 & - & 4.0 & 0.1 & - \\
\hline Echinocactus polycephalus & $=$ & - & 0.3 & - & - & - & - & - & - & - & - & $0: 3$ \\
\hline Echinocereus engelmannii & - & - & $\therefore$ & - & 0.1 & 0.1 & - & - & 0.1 & 0.1 & - & $T$ \\
\hline Encelia virginensis & 0.6 & - & - & - & 1.7 & - & - & 7.7 & - & - & - & - \\
\hline Ephedra nevadensis & 7.7 & 1.1 & 7.9 & 7.8 & 23.7 & 8.2 & 5.9 & 14.7 & 6.5 & 11.5 & 4.2 & 7.8 \\
\hline Ephedra viridis & $=$ & $-\quad 1$ & $\therefore$ & - & - & - & - & - & 0.1 & - & - & - \\
\hline Ericameria cooperi & 3.0 & 2.4 & 2.7 & 2.6 & 1.3 & 0.4 & 2.5 & 6.0 & 0.5 & 3.0 & 1.5 & $=$ \\
\hline Ericameria linearifolia & - & - & - & - & - & - & - & - & $\therefore$ & - & - & - \\
\hline Eriogonum fasciculatum & 0.4 & - & 0.7 & 0.7 & 0.4 & 2.5 & - & 1.7 & 0.5 & 0.2 & 1.5 & 1.2 \\
\hline Eriogonum inflatum & - & - & - & - & $\mathrm{T}$ & - & - & - & - & - & $T$ & $=$ \\
\hline Erioneuron pulchellum & 1.3 & - & 4.7 & 0.3 & 0.1 & 13.0 & - & - & 13.1 & 0.1 & - & 0.2 \\
\hline Grayia spinosa & 1.5 & 0.1 & 1.0 & 0.4 & 0.8 & 1.2 & 0.9 & - & 0.3 & $-\quad$ & 1.0 & 0.6 \\
\hline Gutierrezia sarothrae & - & - & - & - & - & - & - & - & 0.1 & $\therefore$ & & - \\
\hline Hymenoclea salsola & 6.9 & 1.8 & 0.3 & 0.6 & 0.1 & - & 9.8 & 7.0 & 0.1 & 2.1 & 3.0 & - \\
\hline Krameria erecta & 0.1 & - & 23.2 & 22.4 & 27.8 & 17.6 & - & 10.2 & 17.4 & 3.0 & 0.5 & 18.0 \\
\hline Krascheninnikovia lanata & 0.3 & - & 1.3 & 2.3 & 0.5 & 3.1 & 1.2 & 0.6 & 0.6 & 0.5 & 3.5 & 0.1 \\
\hline Larrea tridentata & 6.7 & 7.4 & 3.9 & 4.0 & 4.7 & 5.4 & 7.6 & 2.9 & 6.6 & 3.2 & 9.1 & 7.6 \\
\hline
\end{tabular}




\begin{tabular}{|c|c|c|c|c|c|c|c|c|c|c|c|c|}
\hline Species & LLG1T & LLG2T & LLG3C & LLG4C & LLG4T & LLG5C & LLG5T & LLG6T & LLG7C & LLG7T & LLG8C & LLG9C \\
\hline Lepidium fremontii & - & $-\quad$ & $\begin{array}{r}-\quad ! \\
\end{array}$ & - & - & - & $T$ & $\mathrm{~T}$ & $\therefore$ & - & - & - \\
\hline Lycium andersonii & 5.3 & 0.9 & $5.2 !$ & 2.7 & 8.1 & 3.8 & 3.9 & 1.7 & 2.3 & 5.2 & 5.7 & 1.6 \\
\hline Lycium pallidum & 0.1 & - & 4.3 & 1.9 & - & 3.3 & - & 0.4 & 1.4 & - & - & 1.2 \\
\hline Menodora spinescens & 0.2 & - & 2.1 & 0.3 & 0.9 & 0.3 & 2.3 & 0.9 & 0.3 & 18.2 & - & 4.1 \\
\hline Mirabilis bigelovii & - & - & 0.1 & - & 1.1 & $\dot{0.5}$ & $\mathrm{~T}$ & $-\quad$ & 0.4 & - & - & $\mathrm{T}$ \\
\hline Opuntia basilaris & 0.2 & - & 0.3 & 0.1 & 0.1 & - & - & - & - & 0.1 & - & - \\
\hline Opuntia echinocarpa & 0.1 & - & - & - & - & - & - & 0.1 & - & 0.3 & - & - \\
\hline Oryzopsis hymenoides & - & - & $\mathrm{T}$ & - & 0.3 & 0.1 & - & 0.6 & 0.4 & 0.2 & - & - \\
\hline Psorothamnus fremontii & - & - & - & - & - & - & - & - & - & 0.4 & - & - \\
\hline Salazaria mexicana & 1.8 & 2.5 & $\therefore 0.4$ & 0.9 & 3.0 & 0.8 & 0.5 & 3.2 & 0.4 & 0.1 & 0.5 & 0.3 \\
\hline Sclerocactus polyancistrus & - & - &.$\quad 1$ & - & - & $-\quad$ & - & - & - & - & - & - \\
\hline Sphaeralcea ambigua & 0.2 & 0.2 & T & $\therefore$ & 0.3 & 0.3 & 1.1 & 0.2 & - & 0.3 & - & 0.2 \\
\hline Stephanomeria pauciflora & 0.1 & 0.1 & - & 1.4 & 0.1 & - & 0.2 & $T$ & 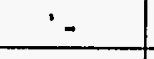 & 0.3 & - & 1.6 \\
\hline Stipa speciosa & 0.9 & 0.8 & - & 1.9 & 2.8 & 2.5 & 0.7 & 0.2 & 0.8 & 0.1 & 1.8 & 0.2 \\
\hline Tetradymia axillaris & - & - & - & - & - & - & 0.1 & - & $-\div$ & - & - & - \\
\hline Xylorhiza tortifolia & 0.1 & - & - & - & - & - & - & - & $\mathrm{T}$ & - & - & 0.1 \\
\hline
\end{tabular}




\section{APPENDIX D}

Net annual aboveground primary production at Yucca Mountain, Nevada, from 1989 to 1994. 


\section{APPENDIX D1}

Net annual aboveground primary production (NAAP) $\left(\mathrm{g} \mathrm{m}^{-2}\right)$ for Ecological Study Plots (ESPs) in 1989 at Yucca Mountain, Nevada.

\begin{tabular}{|c|c|c|c|c|}
\hline \multirow[b]{2}{*}{ ESP } & \multicolumn{4}{|c|}{ Biomass $\left(\mathrm{g} \mathrm{m}^{-2}\right)$} \\
\hline & Shrubs & $\begin{array}{c}\text { Perennial } \\
\text { Forbs and } \\
\text { Grasses } \\
\end{array}$ & Annuals & Total \\
\hline COL1C &.$\quad 0.00$ & 0.00 & 0.00 & 0.00 \\
\hline COL2C & 0.00 & 0.00 & 0.00 & 0.00 \\
\hline COL3C & 0.00 & 0.00 & 0.00 & 0.00 \\
\hline COL $4 C$ & 0.00 & 0.00 & 0.00 & 0.00 \\
\hline COLIT & 0.00 & 0.00 & 0.00 & 0.00 \\
\hline COL2T & 0.00 & 0.00 & 0.00 & 0.00 \\
\hline COL3T & 0.13 & 0.00 & 0.00 & 0.13 \\
\hline COL6T & 0.00 & 0.00 & 0.00 & 0.00 \\
\hline $\mathrm{LA} 2 \mathrm{C}$ & 0.00 & 0.00 & 0.00 & 0.00 \\
\hline $\mathrm{LA} 3 \mathrm{C}$ & 0.00 & 0.00 & 0.00 & 0.00 \\
\hline $\mathrm{LA} 4 \mathrm{C}$ & 0.00 & 0.00 & 0.00 & 0.00 \\
\hline LA5C & 0.00 & 0.00 & 0.00 & 0.00 \\
\hline LA6C & 1.13 & 0.00 & 0.00 & 1.13 \\
\hline LA7C & 0.00 & 0.00 & 0.00 & 0.00 \\
\hline LAIT & 0.00 & 0.00 & 0.00 & 0.00 \\
\hline LA2T & 0.00 & 0.00 & 0.00 & 0.00 \\
\hline LA3T & 0.00 & 0.00 & 0.00 & 0.00 \\
\hline $\mathrm{LA} 4 \mathrm{~T}$ & 0.00 & 0.00 & 0.00 & 0.00 \\
\hline LA5T & 0.00 & 0.00 & 0.00 & 0.00 \\
\hline LA7T & 0.00 & 0.00 & 0.00 & 0.00 \\
\hline $\mathrm{LG} 2 \mathrm{C}$ & 0.001 & 0.00 & 0.00 & 0.00 \\
\hline LG3C & 0.00 & 0.00 & 0.00 & 0.00 \\
\hline LG4C & 0.00 & 0.00 & 0.00 & 0.00 \\
\hline LG3T & 0.01 & 0.00 & 0.00 & 0.01 \\
\hline LG4T & 0.02 & 0.00 & 0.00 & 0.02 \\
\hline LG6T & 0.00 & 0.00 & 0.00 & 0.00 \\
\hline LLG3C & 0.00 & 0.00 & 0.00 & 0.00 \\
\hline LLG4C & 0.51 & 0.00 & 0.00 & 0.51 \\
\hline LLG5C & 0.00 & 0.00 & 0.00 & 0.00 \\
\hline LLG1T & 0.00 & 0.00 & 0.00 & 0.00 \\
\hline LLG2T & 0.00 & 0.00 & 0.00 & 0.00 \\
\hline
\end{tabular}


APPENDIX D1 (continued)

\begin{tabular}{|c|c|c|c|c|}
\hline \multirow[b]{2}{*}{ ESP } & \multicolumn{4}{|c|}{ Biomass $\left(\mathrm{g} \mathrm{m}^{-2}\right)$} \\
\hline & Shrubs & $\begin{array}{c}\text { Perennial } \\
\text { Forbs and } \\
\text { Grasses }\end{array}$ & Annuals & Total \\
\hline LLG3T & 0.00 & $\dot{0} .00$ & 0.00 & 0.00 \\
\hline LLG4T & 1.03 & 0.00 & 0.00 & 1.03 \\
\hline LLG5T & 0.01 & 0.00 & 0.00 & 0.01 \\
\hline LLG6T & 0.00 & 0.00 & 0.00 & 0.00 \\
\hline
\end{tabular}




\section{APPENDIX D2}

Net annual aboveground primary production (NAAP) $\left(\mathrm{g} \mathrm{m}^{-2}\right)$ for Ecological Study Plots (ESPs) in 1990 at Yucca Mountain, Nevada.

\begin{tabular}{|c|r|r|r|r|}
\hline & \multicolumn{4}{|c|}{ Biomass (g m $\left.\mathbf{~}^{-2}\right)$} \\
\cline { 2 - 5 } ESP & Shrubs & $\begin{array}{c}\text { Perennial } \\
\text { Forbs and } \\
\text { Grasses }\end{array}$ & Annuals & Total \\
\hline COL1C & 1.08 & 0.00 & 0.00 & 1.08 \\
\hline COL2C & 1.12 & 0.00 & 0.00 & 1.12 \\
\hline COL3C & 0.37 & 0.00 & 0.02 & 0.39 \\
\hline COL4C & 0.31 & 0.00 & 0.00 & 0.31 \\
\hline COL5C & 6.20 & 0.00 & 0.00 & 6.20 \\
\hline COL6C & 5.09 & 0.00 & 0.00 & 5.09 \\
\hline COL1T & 2.13 & 0.00 & 0.00 & 2.13 \\
\hline COL2T & 1.13 & 0.00 & 0.00 & 1.13 \\
\hline COL3T & 0.63 & 0.00 & 0.00 & 0.63 \\
\hline COL4T & 2.79 & 0.00 & 0.00 & 2.79 \\
\hline COL5T & 2.54 & 0.00 & 0.00 & 2.54 \\
\hline COL6T & 1.36 & 0.00 & 0.00 & 1.36 \\
\hline LA2C & 0.35 & 0.00 & 0.00 & 0.35 \\
\hline LA3C & 0.35 & 0.00 & 0.00 & 0.35 \\
\hline LA4C & 0.46 & 0.00 & 0.00 & 0.46 \\
\hline LA5C & 0.11 & 0.00 & 0.00 & 0.11 \\
\hline LA6C & 2.06 & 0.02 & 0.00 & 2.08 \\
\hline LA7C & 0.07 & 0.00 & 0.00 & 0.07 \\
\hline LȦ1T & 1.39 & 0.00 & 0.00 & 1.39 \\
\hline LA2T & 0.13 & 0.00 & 0.00 & 0.13 \\
\hline LA3T & 0.45 & 0.00 & 0.00 & 0.45 \\
\hline LA4T & 0.45 & 0.00 & 0.00 & 0.45 \\
\hline LA5T & 0.32 & 0.00 & 0.00 & 0.32 \\
\hline LA7T & 4.62 & 0.08 & 0.00 & 4.70 \\
\hline LG1C & 5.53 & 1.75 & 0.12 & 7.41 \\
\hline LG2C & 2.61 & 1.43 & 0.00 & 4.04 \\
\hline LG3C & 2.17 & 0.29 & 0.03 & 2.49 \\
\hline LG4C & 1.70 & 0.27 & 0.01 & 1.98 \\
\hline LG5C & 3.98 & 0.11 & 0.00 & 4.09 \\
\hline LG6C & 3.21 & 0.56 & 0.03 & 3.81 \\
\hline LG2T & 5.39 & 0.22 & 0.00 & 5.61 \\
\hline & & & & \\
\hline
\end{tabular}


APPENDIX D2 (continued)

\begin{tabular}{|c|c|c|c|c|}
\hline \multirow[b]{2}{*}{ ESP } & \multicolumn{4}{|c|}{ Biomass $\left(\mathrm{g} \mathrm{m}^{-2}\right)$} \\
\hline & Shrubs & $\begin{array}{c}\text { Perennial } \\
\text { Forbs and } \\
\text { Grasses }\end{array}$ & Annuals & Total \\
\hline LG3T & 3.61 & 2.49 & 0.00 & 6.11 \\
\hline LG4T & 4.49 & 0.38 & 0.01 & 4.88 \\
\hline LG5T & 6.13 & 0.09 & 0.01 & 6.23 \\
\hline LG6T & 2.24 & .0 .54 & 0.00 & 2.78 \\
\hline LG7T & 2.38 & 0.45 & 0.01 & 2.83 \\
\hline LLG3C & 1.40 & 0.00 & 0.00 & 1.40 \\
\hline LLG4C & 1.52 & 0.00 & 0.00 & 1.52 \\
\hline LLG5C & 1.82 & 0.00 & 0.00 & 1.82 \\
\hline LLG7C & 1.57 & 0.00 & 0.00 & $\cdot 1.57$ \\
\hline LLG8C & 1.45 & 0.00 & 0.00 & 1.45 \\
\hline LLG9C & 1.42 & 0.00 & 0.00 & 1.42 \\
\hline LLGIT & 1.95 & 0.00 & 0.00 & 1.95 \\
\hline LLG2T & 0.96 & 0.00 & 0.10 & 1.06 \\
\hline LLG4T & 1.20 & 0.02 & 0.02 & 1.24 \\
\hline LLG5T & $2: 27$ & 0.00 & 0.00 & 2.27 \\
\hline LLG6T & 0.57 & 0.00 & 0.03 & 0.60 \\
\hline
\end{tabular}




\section{-APPENDIX D3}

Net annual aboveground primary production (NAAP) $\left(\mathrm{g} \mathrm{m}^{-2}\right)$ for Ecological Study Plots (ESPs) in 1991 at Yucca Mountain, Nevada.

\begin{tabular}{|c|c|c|c|c|}
\hline \multirow[b]{2}{*}{ ESP } & \multicolumn{4}{|c|}{ Biomass $\left(\mathrm{g} \mathrm{m}^{-2}\right)$} \\
\hline & Shrubs & $\begin{array}{c}\text { Perennial } \\
\text { Forbs and } \\
\text { Grasses }\end{array}$ & Annuals & Total \\
\hline COL1C & 3.48 & 0.02 & 10.43 & 13.93 \\
\hline COL2C & 5.93 & 0.00 & 9.67 & 15.60 \\
\hline COL3C & 13.30 & 0.00 & 9.81 & 23.11 \\
\hline COLAC & 5.28 & 0.01 & 11.58 & 16.87 \\
\hline COL5C & 17.25 & 0.14 & 15.41 & 32.80 \\
\hline COL6C & 14.77 & 0.04 & 25.52 & 40.33 \\
\hline COLIT & 15.24 & 0.01 & 7.67 & 22.92 \\
\hline COL2T & 12.53 & 0.00 & 5.37 & 17.91 \\
\hline COL3T & 5.04 & 0.14 & 6.29 & 11.46 \\
\hline COLAT & 6.97 & 0.05 & 18.91 & 25.92 \\
\hline COL5T & 21.27 & 0.74 & 15.28 & 37.29 \\
\hline COL6T & 8.51 & 0.00 & 4.29 & 12.80 \\
\hline $\mathrm{LA} 2 \mathrm{C}$ & 33.15 & 0.00 & 4.14 & 37.29 \\
\hline LA.3C & 19.01 & 0.00 & 2.33 & 21.34 \\
\hline LA4C & 17.20 & 0.00 & 3.39 & 20.59 \\
\hline LA5C & 12.32 & 0.03 & 4.19 & 16.53 \\
\hline LA6C & 11.01 & 0.09 & 2.40 & 13.50 \\
\hline LA7C & 16.49 & 0.00 & 10.99 & 27.48 \\
\hline LAlT. & 22.13 & 0.08 & 3.36 & 25.57 \\
\hline LA2T & 12.60 & 0.00 & 3.81 & 16.41 \\
\hline LA3T & 8.77 & 0.00 & 6.26 & 15.03 \\
\hline LA4T & 16.03 & 0.00 & 2.55 & 18.59 \\
\hline LA5T & 17.82 & 0.00 & 2.08 & 19.89 \\
\hline LA7T & 16.15 & 0.15 & 3.48 & 19.77 \\
\hline LGIC & 20.73 & 7.06 & 6.21 & 34.00 \\
\hline LG2C & 25.24 & 5.12 & 7.16 & 37.53 \\
\hline LG3C & $25.19 !$ & 1.45 & 6.40 & 33.04 \\
\hline LG4C & 24.22 & 0.42 & 5.42 & 30.05 \\
\hline LG5C & 17.57 & 1.73 & 5.79 & 25.09 \\
\hline LG6C & 14.48 & 0.82 & 4.50 & 19.80 \\
\hline LG2T & 17.28 & 0.15 & 11.51 & 28.93 \\
\hline
\end{tabular}


APPENDIX D3 (continued)

\begin{tabular}{|c|r|r|r|r|}
\hline & \multicolumn{4}{|c|}{ Biomass $\left(\mathrm{g} \mathrm{m}^{-2}\right)$} \\
\cline { 2 - 5 } ESP & \multicolumn{1}{|c|}{$\begin{array}{c}\text { Perennial } \\
\text { Forbs and } \\
\text { Grasses }\end{array}$} & \multicolumn{1}{c|}{ Annuals } & \multicolumn{1}{c|}{ Total } \\
\hline LG3T & 15.44 & 5.55 & 6.62 & 27.61 \\
\hline LG4T & 14.83 & 3.20 & 5.93 & 23.96 \\
\hline LG5T & 21.56 & 1.51 & 6.82 & 29.89 \\
\hline LG6T & 17.38 & 2.54 & 10.76 & 30.68 \\
\hline LG7T & 13.83 & 1.12 & 3.65 & 18.60 \\
\hline LLG3C & 9.61 & 0.11 & 18.54 & 28.26 \\
\hline LLG4C & 15.34 & 0.24 & 21.53 & 37.11 \\
\hline LLG5C & 8.33 & 0.13 & 23.96 & 32.42 \\
\hline LLG7C & 11.50 & 0.85 & 6.43 & 18.78 \\
\hline LLG8C & 10.09 & 0.24 & 19.10 & 29.43 \\
\hline LLG9C & 11.32 & 0.17 & 11.72 & 23.21 \\
\hline LLG1T & 14.39 & 0.03 & 21.02 & 35.43 \\
\hline LLG2T & 7.83 & 0.02 & 18.20 & 26.05 \\
\hline LLG4T & 10.39 & 0.12 & 28.24 & 38.76 \\
\hline LLG5T & 12.35 & 0.00 & 16.82 & 29.18 \\
\hline LLG6T & 10.70 & 0.54 & 9.48 & 20.72 \\
\hline LLG7T & 15.02 & 0.00 & 14.11 & 29.13 \\
\hline
\end{tabular}




\section{APPENDIX D4}

Net annual aboveground primary production (NAAP) $\left(\mathrm{g} \mathrm{m}^{-2}\right)$ for Ecological Study Plots (ESPs) in 1992 at Yucca Mountain, Nevada.

\begin{tabular}{|c|r|r|r|r|}
\hline & \multicolumn{4}{|c|}{ Biomass $\left(\mathrm{g} \mathrm{m}^{-2}\right)$} \\
\cline { 2 - 5 } ESP & Shrubs & $\begin{array}{c}\text { Perennial } \\
\text { Forbs and } \\
\text { Grasses }\end{array}$ & Annuals & Total \\
\hline COL1C & 15.88 & 0.36 & 32.33 & 48.56 \\
\hline COL2C & 16.35 & 0.11 & 15.71 & 32.17 \\
\hline COL3C & 13.23 & 0.08 & 11.27 & 24.59 \\
\hline COL4C & 19.49 & 0.09 & 18.68 & 38.25 \\
\hline COL5C & 15.57 & 0.40 & 18.28 & 34.25 \\
\hline COL6C & 27.38 & 0.67 & 16.15 & 44.20 \\
\hline COL1T & 20.13 & 0.99 & 13.61 & 34.73 \\
\hline COL2T & 18.84 & 0.48 & 13.93 & 33.25 \\
\hline COL3T & 17.61 & 0.39 & 14.37 & 32.38 \\
\hline COL4T & 12.51 & 0.18 & 19.03 & 31.72 \\
\hline COL5T & 51.23 & 0.91 & 21.55 & 73.69 \\
\hline COL6T & 28.08 & 0.40 & 10.97 & 39.46 \\
\hline LA2C & 29.62 & 0.06 & 9.15 & 38.83 \\
\hline LA3C & 36.05 & 0.27 & 7.23 & 43.56 \\
\hline LA4C & 38.98 & 0.09 & 8.08 & 47.16 \\
\hline LA5C & 14.35 & 0.62 & 12.15 & 27.11 \\
\hline LA6C & 33.36 & 0.19 & 9.18 & 42.73 \\
\hline LA7C & 24.24 & 0.57 & 15.86 & 40.67 \\
\hline LA1T & 42.79 & 0.01 & 12.06 & 54.86 \\
\hline LA2T & 26.82 & 0.28 & 17.15 & 44.24 \\
\hline LA3T & 38.64 & 0.12 & 12.73 & 51.48 \\
\hline LA4T & 35.40 & 0.01 & 16.40 & 51.80 \\
\hline LA5T & 25.54 & 0.00 & 9.67 & 35.21 \\
\hline LA7T & 45.19 & 0.29 & 10.89 & 56.37 \\
\hline LG1C & 8.22 & 3.26 & 13.10 & 24.57 \\
\hline LG2C & 18.00 & 3.24 & 23.62 & 44.86 \\
\hline LG3C & 30.46 & 2.14 & 10.37 & 42.96 \\
\hline LG4C & 24.15 & 1.26 & 12.76 & 38.18 \\
\hline LG5C & 25.62 & 2.20 & 10.62 & 38.44 \\
\hline LG6C & 25.75 & 1.88 & 13.90 & 41.53 \\
\hline LG2T & 26.53 & 0.75 & 15.67 & 42.95 \\
\hline
\end{tabular}


APPENDIX D4 (continued)

\begin{tabular}{|c|r|r|r|r|}
\hline & \multicolumn{4}{|c|}{ Biomass $\left(\mathrm{g} \mathrm{m}^{-2}\right)$} \\
\cline { 2 - 5 } & \multicolumn{2}{|c|}{$\begin{array}{c}\text { Perennial } \\
\text { Forbs and } \\
\text { Grasses }\end{array}$} & \multicolumn{1}{c|}{ Annuals } & Total \\
\hline LG3T & 22.14 & 7.34 & 11.50 & 40.98 \\
\hline LG4T & 22.17 & 3.90 & 13.86 & .39 .93 \\
\hline LG5T & 18.63 & 2.88 & 10.57 & 32.07 \\
\hline LG6T & 37.47 & 2.33 & 15.45 & 55.25 \\
\hline LG7T & 19.77 & 3.16 & 15.32 & 38.25 \\
\hline LLG3C & 18.56 & 2.12 & 37.49 & 58.17 \\
\hline LLG4C & 11.55 & 1.73 & 39.58 & 52.86 \\
\hline LLG5C & 23.38 & 1.21 & 55.02 & 79.62 \\
\hline LLG7C & 20.30 & 2.06 & 23.75 & 46.11 \\
\hline LLG8C & 10.74 & 0.36 & 46.87 & 57.97 \\
\hline LLG9C & 24.01 & 3.40 & 33.64 & 61.04 \\
\hline LLG1T & 27.92 & 0.86 & 45.91 & 74.69 \\
\hline LLG2T & 20.95 & 1.63 & 65.61 & 88.19 \\
\hline LLG4T & 18.09 & 3.98 & 47.05 & 69.12 \\
\hline LLG5T & 46.78 & 0.12 & 61.34 & 108.25 \\
\hline LLG6T & 19.90 & 1.35 & 35.13 & 56.38 \\
\hline LLG7T & 40.43 & 0.18 & 26.65 & 67.27 \\
\hline
\end{tabular}




\section{APPENDIX D5}

Net annual aboveground primary production (NAAP) $\left(\mathrm{g} \mathrm{m}^{-2}\right)$ for Ecological Study Plots (ESPs) in 1993 at Yucca Mountain, Nevada. Data were not collected for ESPs in Coleogyne, LarreaAmbrosia; or Lycium-Grayia vegetation associations.

\begin{tabular}{|c|r|r|r|r|}
\hline & \multicolumn{4}{|c|}{ Biomass $\left(\mathbf{g ~ m}^{-2}\right)$} \\
\cline { 2 - 5 } ESP & \multicolumn{1}{|c|}{$\begin{array}{c}\text { Perennial } \\
\text { Forbs and } \\
\text { Grasses }\end{array}$} & \multicolumn{1}{c|}{ Annuals } & Total \\
\hline LLG3C & 23.77 & 4.29 & 22.46 & 50.52 \\
\hline LLG4C & 27.98 & 2.81 & 27.80 & 58.59 \\
\hline LLG5C & 28.21 & 0.80 & 31.81 & 60.81 \\
\hline LLG7C & 24.08 & 4.73 & 22.29 & 51.10 \\
\hline LLG8C & 17.00 & 0.70 & 58.32 & 76.01 \\
\hline LLG9C & 40.75 & 4.42 & 15.94 & 61.11 \\
\hline LLG1T & 24.42 & 1.73 & 32.20 & 58.35 \\
\hline LLG2T & 18.59 & 1.82 & 84.10 & 104.51 \\
\hline LLG4T & 55.25 & 4.35 & 21.04 & 80.63 \\
\hline LLG5T & 28.23 & 0.19 & 39.09 & 67.50 \\
\hline LLG6T & 33.14 & 0.91 & 33.62 & 67.67 \\
\hline LLG7T & 25.91 & 0.10 & 29.98 & 56.00 \\
\hline
\end{tabular}




\section{APPENDIX D6}

Net annual aboveground primary production (NAAP) $\left(\mathrm{g} \mathrm{m}^{-2}\right)$ for Ecological Study Plots (ESPs) in 1994 at Yucca Mountain, Nevada. Data were not collected for ESPs in Coleogyne, LarreaAmbrosia, or Lycium-Grayia vegetation associations. Shrub lifeform was not sampled.

\begin{tabular}{|c|c|c|c|c|}
\hline \multirow[b]{2}{*}{ ESP } & \multicolumn{4}{|c|}{ Biomass $\left(\mathrm{g} \mathrm{m}^{-2}\right)$} \\
\hline & Shrubs & \begin{tabular}{|c|} 
Perennial \\
Forbs and \\
Grasses \\
\end{tabular} & Annuals & Total \\
\hline LLG3C & - & 0.12 & 1.81 & - \\
\hline LLG4C & - & 0.19 & 2.56 & - \\
\hline LLG5C & - & 0.29 & 1.92 & - \\
\hline LLG7C & - & 0.00 & 1.87 & - \\
\hline LLG8C & - & 0.53 & 6.53 & - \\
\hline LLG9C & - & 0.00 & 4.24 & - \\
\hline LLGIT & - & 0.41 & 6.98 & - \\
\hline LLG2T & - & 0.08 & 10.58 & - \\
\hline LLG4T & - & 0.23 & 4.25 & - \\
\hline LLG5T & - & 0.00 & 6.48 & - \\
\hline LLG6T & - & 0.21 & 0.77 & - \\
\hline LLG7T & - & 0.00 & 2.73 & - \\
\hline
\end{tabular}




\section{APPENDIX E}

Species composition and percent cover on each Ecological Study Plot at Yucca Mountain, Nevada. 
Average percent plant cover on 12 Ecological Study Plots in the Coleogyne vegetation association at Yucca Mountain, Nevada, during 1989-1994. Species with less than $0.1 \%$ cover are indicated with a "T"; species not present are indicated with a "-."”

\begin{tabular}{|c|c|c|c|c|c|c|c|c|c|c|c|c|}
\hline Species & COL1C & COLIT & COL2C & COL2T & COL3C & COL3T & $\mathrm{COL} 4 \mathrm{C}$ & COL4T & COL5C & COL5T & COL6C & COL6T \\
\hline Acamplopappus shockleyi & $\mathrm{T}$ & $\mathrm{T}$ & - & - & $T$ & - & - & - & - & - & - & - \\
\hline Ambrosia dumosa & 1.9 & 1.5 & 1.6 & 2.3 & 1.2 & 2.3 & 1.6 & - & - & $\mathrm{T}$ & - & 4.3 \\
\hline Amsinckia tessellata & 1.2 & 0.7 & 0.5 & 0.5 & 0.5 & 0.6 & 0.9 & 1.2 & 0.6 & 0.4 & 0.4 & 0.4 \\
\hline Aristida purpurea & - & - & - & - & - & - & - & $-\quad$ & - & - & $-\quad$ & - \\
\hline Artemisia spinescens & - & - & - & - & - & - & - & - & - & $T$ & - & - \\
\hline Artemisia tridentata & - & - & - & - & - & - & - & - & - & - & - & - \\
\hline Astragalus acutirostris & $T$ & - & $\mathrm{T}$ & - & - & - & - & - & - & - & $T$ & - \\
\hline Astragalus layneae & - & $\mathrm{T}$ & - & $\mathrm{T}$ & $\mathrm{T}$ & $\mathrm{T}$ & - & - & - & - & - & - \\
\hline Atriplex canescens & - & $\mathrm{T}$ & - & - & - & $-\cdot$ & $\cdot \mathrm{T}$ & 0.1 & - & $\mathrm{T}$ & - & $\mathrm{T}$ \\
\hline Atriplex conferifolia & $\therefore$ & 0.5 & 0.4 & 0.3 & 0.4 & 1.0 & 0.7 & - & - & $\begin{array}{r}\cdot \quad 0.8 \\
\end{array}$ & $=$ & 0.4 \\
\hline Atriplex polycarpa & 二 & -1 & $-\quad$ & - & $-\quad$ & $-\quad$ & - & - & - & - & - & - \\
\hline Brickellia microphylla & - & - & - & - & $\therefore$ & - & - & - & - & - & - & - \\
\hline Bromus rubens & 5.3 & .3 .4 & 2.8 & 3.3 & 3.3 & 3.5 & 3.5 & 4.8 & $5: 0$ & 9.2 & 5.6 & 2.3 \\
\hline Bromus tectorum & - & - & - & $\mathrm{T}$ & - & - & - & 0.2 & 0.5 & $T$ & 0.3 & - \\
\hline Calochortus flexuosus & - & - & - & - & - & - & - & - & 0.1 & $\mathrm{~T}$ & $T$ & - \\
\hline Camissonia brevipes & $=$ & - & - & - & - & - & $T$ & - & - & - & - & - \\
\hline Castilleja angustifolia & - & - & - & - & - & - & - & - & - & - & - & - \\
\hline Centrostegia thurberi & $=$ & - & - & $T$ & - & - & - & - & - & $T$ & $=$ & $\mathrm{T}$ \\
\hline Chaenactis carphoclinia & - & - & $\mathrm{T}$ & - & $T$ & - & - & - & - & - & $=$ & - \\
\hline Chaenactis fremontii & - & - & - & - & - & $\mathrm{T}$ & - & - & - & - & $=$ & $=$ \\
\hline Chaenactis macrantha & - & - & - & - & - & - & - & - & - & - & $=$ & $=$ \\
\hline Chaenactis stevioides & 0.3 & 0.5 & 0.1 & 0.4 & 0.2 & 0.6 & 0.2 & 0.1 & - & 0.1 & 0.2 & 0.1 \\
\hline Chamaesyce albomarginata & - & - & - & - & $-\quad$ & - & - & $\mathbf{T}$ & $T$ & - & $\mathrm{T}$ & - \\
\hline Chorizanthe brevicornu & 0.3 & 0.2 & 0.3 & 0.1 & 0.4 & 0.3 & 0.2 & $T$ & 0.1 & $T$ & $T$ & 0.2 \\
\hline Chorizanthe rigida & $T$ & $T$ & 0.1 & $T$ & $T$ & $T$ & $T$ & - & - & $\mathrm{I}$ & - & $T$ \\
\hline Chrysothamnus nauseosus & - & - & $-\quad 1$ & - & - & $T$ & - & - & 0.1 & {$\left[\begin{array}{l}0.2 \\
-\end{array}\right.$} & $=$ & $T$ \\
\hline
\end{tabular}




\begin{tabular}{|c|c|c|c|c|c|c|c|c|c|c|c|c|}
\hline Species & COL1C & COL1T & COL2C & COL2T & COL3C & COL3T & COL4C & COL4T & COL5C & COL5T & COL6C & COL6T \\
\hline Chrysothamnus teretifolius & - & - & - & - & - & - & - & 0.3 & 0.8 & \begin{tabular}{|r|}
1.2 \\
\end{tabular} & 0.4 & - \\
\hline Chrysothamnus viscidiflorus & - & - & - & - & - & - & - & 0.2 & $\mathrm{~T}$ & 0.4 & $\mathrm{~T}$ & - \\
\hline Cirsium neomexicanum & - & - & - & - & - & - & - & - & - & $-\quad$ & - & - \\
\hline Coleogyne ramosissima & 3.5 & 2.9 & 3.4 & 3.0 & 3.1 & 2.6 & 2.9 & 7.4 & 12.5 & 10.5 & 12.2 & 2.7 \\
\hline Cryptantha circumscissa & $\mathrm{T}$ & $\mathrm{T}$ & $T$ & $T$ & $T$ & $\mathrm{~T}-$ & 0.2 & $\mathrm{~T}$ & - & $\mathrm{T}$ & - & $\mathrm{T}$ \\
\hline Cryptantha micrantha & $\mathrm{T}$ & $\mathrm{T}$ & - & - & - & $\mathrm{T}$ & - & - & - & - & - & - \\
\hline Cryptantha nevadensis & 0.5 & $\mathrm{~T}$ & 0.3 & $\mathrm{~T}$ & 0.2 & 0.2 & 0.5 & 0.1 & $\mathrm{~T}$ & $\mathrm{~T}$ & $\mathrm{~T}$ & - \\
\hline Cryptantha pterocarya & $\mathrm{T}$ & $\mathrm{T}$ & $\mathrm{T}$ & $\mathrm{T}$ & $\mathrm{T}$ & 0.1 & - & $\mathrm{T}-$ & - & 0.1 & $\mathrm{~T}$ & $\mathrm{~T}$ \\
\hline Cuscuta denticulata & - & - & - & - & - & - & - & - & - & - & - & - \\
\hline Dalea mollissima & $=$ & - & $\therefore$ & - & - & - & - & - & - & - & - & - \\
\hline Delphinium parishii & - & - & - & - & - & - & - & - & - & $\mathrm{T}$ & - & - \\
\hline Descurainia pinnata & - & $\mathrm{T}$ & $\mathrm{T}$ & 0.1 & $\mathrm{~T}$ & - & - & 1.1 & 0.3 & 0.4 & 0.3 & - \\
\hline Dichelostemma congestum & - & - & - & - & - & - & - & 0.1 & 0.2 & $T$ & 0.1 & - \\
\hline Echinocactus polycephalus & - & $=$ & - & - & - & - & - & - & $\mathrm{T}$ & - & - & - \\
\hline Echinocereus engelmannii & - & $\therefore$ & - & - & - & - & - & - & $\mathrm{T}$ & - & - & - \\
\hline Elymus elymoides & - & - & - & - & - & - & - & - & - & $\mathrm{T}$ & - & - \\
\hline Elymus multisetus & - & $=$ & - & - & - & - & - & - & - & - & - & - \\
\hline Encelia virginensis & $\mathrm{T}$ & 0.5 & 0.2 & 0.4 & 0.9 & 0.6 & $\because$ & $-\cdot$ & $-\quad \cdot$ & - & $=$ & 0.5 \\
\hline Ephedra nevadensis & 1.5 & 2.7 & 1.5 & 1.9 & -1.5 & -1.7 & 1.4 & 1.7 & 1.0 & 2.0 & 2.7 & 1.2 \\
\hline Ephedra viridis & - & - & - & - & - & - & - & - & 0.4 & 0.3 & 0.6 & - \\
\hline Eriastrum eremicum & $T$ & - & - & $\ldots$ & - & - & - & 0.2 & - & 0.2 & $\mathrm{~T}$ & $\mathrm{~T}$ \\
\hline Eriastrum sparsiflorum & $=$ & - & $\therefore$ & - & - & - & $\therefore$ & $\mathrm{T}$ & - & - & - & - \\
\hline Ericameria cooperi & $T$ & 0.1 & $T$ & 0.3 & 0.1 & $\mathrm{~T}$ & $\mathrm{~T}$ & $\mathrm{~T}$ & 0.3 & 0.6 & 0.2 & $\mathrm{~T}$ \\
\hline Ericameria linearifolia & 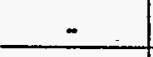 & - & - & - & $-\quad \cdot$ & - & - & $\mathrm{T}$ & $\mathrm{T}$ & 0.1 & $T$ & $=$ \\
\hline Eriogonum deflexum & - & - & $T$ & $\mathrm{~T}$ & - & - & - & - & $\mathrm{T}$ & $=$ & $\mathrm{T}$ & $\mathrm{T}$ \\
\hline Eriogonum fasciculatum & 0.1 & 0.2 & 0.4 & 0.2 & 0.2 & 0.2 & $T$ & $\mathrm{~T}$ & - & 0.3 & - & 0.1 \\
\hline Eriogonum inflatum & $\mathrm{T}$ & 0.1 & $T$ & $\mathrm{~T}$ & $T$ & - & $\mathrm{T}$ & - & $\mathrm{T}$ & - & $=$ & $T$ \\
\hline Eriogonum maculatum & - & - & - & - & - & $\mathrm{T}$ & - & $\mathrm{T}$ & - & $\Sigma$ & $\therefore$ & $\therefore$ \\
\hline Eriogonum microthecum & - & - & $T$ & - & - & - & - & - & $=$ & - & - & - \\
\hline
\end{tabular}




\begin{tabular}{|c|c|c|c|c|c|c|c|c|c|c|c|c|}
\hline $\begin{array}{r}\text { Species } \\
\end{array}$ & $\mid$ COL1C & COLIT & COL2C & COL2T & COL3C & COL3T & COLAC & COL4T & COLSC & COL5T & COL6C & COL6T \\
\hline Eriogonum nidularium & 0.1 & - & 0.1 & $T$ & $T$ & $\mathrm{~T}$ & $\mathrm{~T}$ & 0.1 & 0.2 & 0.5 & $T$ & - \\
\hline Erioneuron pulchellum & - & - & - & - & - & - & - & $-\quad$ & $=$ & $-\quad$ & $=$ & - \\
\hline Eriophyllum pringlei & - & $\mathrm{T}$ & $\mathrm{T}$ & $\mathrm{T}$ & $\mathrm{T}$ & $\mathrm{T}$ & $\mathrm{T}$ & $=$ & - & $\mathrm{T}$ & $=$ & $\mathrm{T}$ \\
\hline Erodium cicularium & 0.2 & 0.2 & 0.3 & $T$ & 0.2 & $\mathrm{~T}$ & 0.6 & 0.4 & - & $T$ & 0.2 & $\mathrm{~T}$ \\
\hline Eschscholsia minutiflora & -1 & -1 & $-\quad 1$ & - & - & - & - & $=$ & - & - & - & - \\
\hline Grayia spinosa & 0.9 & 0.5 & 0.2 & 0.1 & 0.5 & $T$ & 0.4 & 0.1 & 1.1 & 0.7 & 0.5 & 0.2 \\
\hline Gutierrezia sarothrae & $-\quad 1$ & - & $=$ & - & - & - & $-\quad$ & $\mathrm{T}$ & - & 0.1 & $\mathrm{~T}$ & - \\
\hline Hilaria jamesii & - & - & - & - & $=$ & - & - & - & $=$ & 0.6 & - & - \\
\hline Hymenoclea salsola & $\mathrm{T}$ & $=1$ & $\mathrm{~T}$ & $\mathrm{~T}$ & - & - & - & 1.3 & $T$ & $\mathrm{~T}$ & $T$ & - \\
\hline Krameria erecia & 0.8 & 1.5 & 1,0 & 1.1 & 1.9 & 0.9 & 2.1 & - & - & - & - & 0.8 \\
\hline Krascheninnikovia lanata & 0.1 & - & $\mathrm{T}$ & - & $T$ & - & $\mathrm{T}$ & - & $=$ & - & - & - \\
\hline Larrea tridentata & 0.6 & 0.9 & 0.3 & 0.1 & 0.3 & $\mathrm{~T}$ & 0.9 & - & - & - & - & 0.3 \\
\hline Lepidium fremontii & - & $=$ & $=$ & $\therefore$ & - & - & - & $=$ & - & - & - & - \\
\hline Lepidium lasiocarpum & $T$ & $=$ & $T$ & $\mathrm{~T}$ & 0.1 & - & - & - & - & - & - & - \\
\hline Loeseliastrum schottii & - & $=$ & $\mathrm{T}$ & - & $\mathrm{T}$ & $\mathrm{T}$ & - & - & - & $=$ & - & - \\
\hline Lomatium nevadense & - & - & $=$ & - & - & - & - & $=$ & $=$ & - & $\mathrm{T}$ & - \\
\hline Lotus humistratus & 0.9 & 0.4 & 0.9 & 0.5 & 0.6 & 0.9 & 0.9 & 0.2 & - & $\mathrm{T}$ & 0.2 & 0.5 \\
\hline Lupinus concinnus & - & $=-$ & - & - & - & - & - & $T$ & $\mathrm{~T}$ & - & $-\quad$. & $T$ \\
\hline Lupinus flavoculatus & $=$ & $=$ & - & - & - & - & - & - & - & $T$ & - & - \\
\hline Lycium andersonii & 0.2 & 0.6 & 0.3 & 0.6 & 0.5 & 0.2 & 0.4 & 0.2 & 0.3 & 1.0 & 0.4 & 0.5 \\
\hline Lycium pallidum & $T$ & 0.8 & $\mathrm{~T}$ & 0.6 & 0.7 & 0.3 & 0.8 & - & $T$ & $\mathrm{~T}$ & - & 1.2 \\
\hline Malacothrix glabrata & $\mathrm{T}$ & $T$ & $\mathrm{~T}$ & - & 0.1 & - & $T$ & $T$ & $\mathrm{~T}$ & $T$ & $\mathrm{~T}$ & $\mathrm{~T}$ \\
\hline Menodora spinescens & 0.1 & 0.3 & 0.7 & 0.3 & 0.4 & 1.4 & $T$ & - & - & - & - & 0.1 \\
\hline Mentzelia obscura & 0.1 & 0.2 & $\mathrm{~T}$ & $\mathrm{~T}$ & 0.1 & 0.1 & $\mathrm{~T}$ & 0.5 & 0.2 & 0.1 & 0.2 & $T$ \\
\hline Mirabilis bigelovii & - & - & - & - & - & - & - & - & - & - & $=$ & - \\
\hline Monoptilon bellidiforme & - & - & $=$ & - & - & - & - & - & - & - & - & $\therefore$ \\
\hline Muhlenbergia porteri & $=$ & $=$ & $\therefore$ & - & - & $=$ & $=$ & - & - & - & - & - \\
\hline Nama demissum & 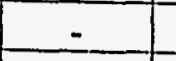 & - & $T$ & $\mathrm{~T}$ & - & - & - & - & - & $=$ & 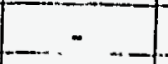 & $\mathrm{T}$ \\
\hline Opuntia basilaris & - & - & - & - & $\therefore$ & - & - & $T$ & $=$ & - & & \\
\hline
\end{tabular}


APPENDIX E1 (continued)

\begin{tabular}{|c|c|c|c|c|c|c|c|c|c|c|c|c|}
\hline Species & COL1C & COL1T & COL2C & COL2T & COL3C & COL3T & COL4C & COL4T & COL5C & COL5T & COL6C & COL6T \\
\hline Opuntia echinocarpa & - & - & $\ldots$ & - & - & - & - & - & $\therefore \cdot$ & - & - & - \\
\hline Oryzopsis hymenoides & - & - & - & - & - & - & - & $\mathrm{T}$ & $=$ & - & - & - \\
\hline Oxytheca perfoliata & 0.2 & 0.2 & 0.2 & 0.3 & 0.3 & 0.3 & $\mathrm{~T}$ & $\mathrm{~T}$ & $\mathbf{T}$ & 0.1 & - & 0.2 \\
\hline Pectocarya platycarpa & 0.6 & $T$ & 0.1 & 0.2 & $\mathrm{~T}$ & 0.2 & $\mathrm{~T}$ & 0.2 & 1.1 & $\mathrm{~T}$ & 0.5 & $\mathrm{~T}$ \\
\hline Pectocarya setosa & 0.8 & $T$ & $\mathrm{~T}$ & 0.2 & $\mathrm{~T}$ & $\mathrm{~T}$ & $\mathrm{~T}$ & 0.4 & 0.7 & $\mathrm{~T}$ & 0.1 & $\mathrm{~T}$ \\
\hline Phacelia crenulata & - & - & - & - & - & $\mathrm{T}$ & - & - & $\ldots$ & $\mathrm{T}$ & - & $\mathrm{T}$ \\
\hline Phacelia fremoniti & $\mathrm{T}$ & 0.1 & $\mathrm{~T}$ & 0.1 & $\mathrm{~T}$ & $\mathrm{~T}$ & $\mathrm{~T}$ & $\mathrm{~T}$ & $\mathrm{~T}$ & - & $\mathrm{T}$ & $\mathrm{T}$ \\
\hline Phacelia vallis-mortae & - & - & - & - & - & - & $\mathrm{T}$ & - & - & $\mathrm{T}$ & - & - \\
\hline Phlox stansburyi & $=$ & - & $\therefore$ & - & - & - & - & - & - & - & - & - \\
\hline Psorothammus fremontii & - & $\therefore$ & $\therefore$ & - & - & - & - & - & - & - & - & $=$ \\
\hline Rafinesquia neomexicana & - & $T$ & $=$ & - & - & - & - & - & - & - & - & $T$ \\
\hline Salazaria mexicana & $\mathrm{T}$ & $\mathrm{T}$ & 0.1 & 0.1 & 0.1 & $\mathrm{~T}$ & - & - & - & - & - & $\mathrm{T}$ \\
\hline Salsola kali & - & - & - & - & - & - & - & $\mathrm{T}$ & $\mathrm{T}$ & $\mathrm{T}$ & - & - \\
\hline Schismus arabicus & - & - & - & - & $=$ & - & - & - & - & - & - & - \\
\hline Sclerocactus polyancistrus & - & $\mathrm{T}$ & - & - & - & - & - & - & - & - & - & - \\
\hline Sisymbrium altissimum & 0.1 & 0.1 & $T$ & $T$ & $T$ & $\mathrm{~T}$ & 0.1 & $\mathrm{~T}$ & - & - & $=$ & $\mathrm{T}$ \\
\hline Sphaeralcea ambigua & - & - & - & - & - & - & - & - & - & $\mathrm{T}$ & - & - \\
\hline Stephanomeria parryi & - & - & $=$ & - & - & - & $\therefore$ & $\mathrm{T}$ & - & $\mathrm{T}$ & - & - \\
\hline Stephanomeria pauciflora & - & $=$ & $=$ & 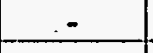 & - & $\mathrm{T}$ & - & $\mathrm{T}$ & $\cdots$ & $\mathrm{T}$ & - & - \\
\hline Stipa speciosa & $\mathrm{T}$ & $\mathrm{T}$ & $\mathrm{T}$ & $T$ & $\mathrm{~T}$ & $T$ & $\mathrm{~T}$ & $\mathrm{~T}$ & 0.1 & 0.2 & - & $T$ \\
\hline Syntrichopappus fremontii & - & $T$ & $\mathrm{~T}$ & - & - & - & - & $\mathrm{T}$ & 0.2 & 0.1 & 0.3 & $\mathrm{~T}$ \\
\hline Tetradymia axillaris & - & $=$ & $=$ & - & - & - & - & 0.2 & - & $\mathrm{T}$ & $=$ & - \\
\hline Tetradymia glabrata & - & $=$ & - & - & - & - & - & - & - & - & - & - \\
\hline Vulpia octoflora & 0.1 & 0.3 & 0.6 & 0.4 & 0.3 & 0.4 & 0.4 & $\mathrm{~T}$ & $\mathrm{~T}$ & $\mathrm{~T}$ & $T$ & 0.3 \\
\hline Xylorhiza tortifolia & $\mathrm{T}$ &. $\mathrm{T}$ & - & $\mathrm{T}$ & - & $\mathrm{T}$ & $\mathrm{T}$ & - & $=$ & - & $=$ & $\mathrm{T}$ \\
\hline Yucca brevifolia & - & - & $\therefore$ & - & - & - & - & - & 0.3 & - & - & - \\
\hline
\end{tabular}




\section{APPENDIX E2}

Average percent plant cover on 12 Ecological Study Plots in the Larrea-Ambrosia vegetation association at Yucca Mountain, Nevada, during 1989-1994. Species with less than $0.1 \%$ cover are indicated with a "T"; species not present are indicated with a "-.".

\begin{tabular}{|c|c|c|c|c|c|c|c|c|c|c|c|c|}
\hline $\begin{array}{r}\text { Species } \\
\end{array}$ & LA1T & LA2C & LA2T & LA3C & LA3T & LA4C & LA4T & LA5C & LAST & LAGC & LA7C & LA7T \\
\hline Acamplopappus shockleyi & 0.9 & 3.8 & 0.6 & 4.3 & 0.3 & 5.1 & 0.2 & 0.2 & 0.6 & $\mathrm{~T}$ & 0.9 & - \\
\hline Ambrosia dumosa & 3.8 & 7.9 & 6.0 & 7.7 & 5.3 & 7.3 & 7.8 & 5.9 & 6.7 & 3.9 & 6.0 & 2.5 \\
\hline Amsinckia ressellata & - & - & - & - & 0.1 & - & $T$ & $\mathrm{~T}$ & 0.1 & - & - & 0.2 \\
\hline Aristida purpurea & - & - & - & - & $-\quad$ & - & - & $=$ & $-\quad$ & - & - & - \\
\hline Artemisia spinescens & - & $=$ & - & - & - & - & - & - & - & - & - & - \\
\hline Artemisia tridentata & - & - & - & - & - & - & - & - & $=$ & - & - & - \\
\hline Astragalus acutirostris & - & - & - & - & $\mathrm{T}$ & $=$ & $\mathrm{T}$ & - & $\mathrm{T}$ & - & - & $T$ \\
\hline Astragalus layneae & $=$ & - & - & - & $\mathrm{T}$ & - & - & - & - & $=$ & - & $\mathrm{T}$ \\
\hline Atriplex canescens & - & - & $=$ & - & - & $\therefore$ & - & - & - & - & - & - \\
\hline Atriplex confertifolia & - & - & - & - & - & - & - & $\mathrm{T}$ & - & 1.5 & - & 0.9 \\
\hline Arriplex polycarpa & - & - & - & - & $\therefore$ & - & - & - & - & - & - & - \\
\hline Brickellia microphylla & - & - & - & $\therefore$ & - & - & - & - & $=$ & - & - & - \\
\hline Bromus rubens & 0.2 & 0.1 & 0.3 & $\mathrm{~T}$ & 1.0 & $T$ & 0.7 & $\mathrm{~T}$ & 0.8 & 0.4 & 1.0 & 0.8 \\
\hline Bromus tectorum & - & - & - & - & - & - & - & - & - & - & - & - \\
\hline Calochortus flexuosus & $=$ & - & - & - & - & - & - & $=$ & - & - & - & - \\
\hline Camissonia brevipes & - & - & - & - & - & - & - & - & - & $\therefore$ & - & - \\
\hline Castilleja angustifolia & - & - & $\mathrm{T}$ & - & - & - & - & - & 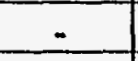 & - & - & $\therefore$ \\
\hline Centrostegia thurberi & - & - & - & - & $\mathrm{T}$ & - & - & $\mathrm{T}$ & $\mathrm{T}$ & - & $T$ & - \\
\hline Chaenactis carphoclinia & $=$ & - & $=$ & $=$ & - & - & - & - & - & $=$ & - & $=$ \\
\hline Chaenactis fremontii & - & - & - & - & - & - & - & - & - & - & - & $=$ \\
\hline Chaenactis macrantha & $\mathrm{T}$ & - & $\mathrm{T}$ & - & - & - & - & - & - & - & - & - \\
\hline Chaenactis stevioides & 1.2 & 0.9 & 2.2 & 0.7 & 0.5 & 0.6 & 0.8 & 2.3 & 0.3 & $\mathrm{~T}$ & 1.6 & 0.1 \\
\hline Chamaesyce albomarginata & - & - & - & - & - & - & - & - & - & - & $=$ & - \\
\hline Chorizanthe brevicornu & $\mathrm{T}$ & - & - & $\mathrm{T}$ & $\mathrm{T}$ & - & $=$ & $\mathrm{T}$ & $\mathrm{T}$ & $\mathrm{T}$ & $\therefore$ & $T$ \\
\hline Chorizanthe rigida & - & - & $=$ & - & - & $=$ & - & - & $T$ & 0.2 & $=$ & 0.1 \\
\hline Chrysothamnus nauseosus & - & - & - & - & - & - &. & - & $=$ & -1 & $\ldots$ & $\ldots-\ldots$ \\
\hline
\end{tabular}


APPENDIX E2 (continued)

\begin{tabular}{|c|c|c|c|c|c|c|c|c|c|c|c|c|}
\hline Species & LA1T & LA2C & LA2T & LA3C & LA3T & LA4C & LA4T & LASC & LAST & LA6C & LA7C & LA7T \\
\hline Chrysothammus teretifolius & - & - & - & - & - & - & - & - & - & - & - & - \\
\hline Chrysothamnus viscidiflorus & - & - & - & - & $\therefore$ & - & - & - & - & - & - & - \\
\hline Cirsium neomexicamum & $-\quad$. & - & - & - & - & - & - & - & - & - & - & - \\
\hline Coleogyne ramosissima & 2.8 & - & - & - & - & - & 0.8 & - & - & - & - & - \\
\hline Cryptantha circumscissa & $-\quad 1$ & $\mathrm{~T}$ & $\mathrm{~T}$ & - & $\mathrm{T}$ & - & 0.1 & $\mathrm{~T}$ & $\mathrm{~T}$ & $\mathrm{~T}$ & $\mathrm{~T}$ & $\mathrm{~T}$ \\
\hline Cryptantha micrantha & $\mathrm{T}$ & - & 0.1 & - & 0.2 & $\mathrm{~T}$ & $\mathrm{~T}$ & $\mathrm{~T}$ & 0.1 & - & $\mathrm{T}$ & $\mathrm{T}$ \\
\hline Cryptantha nevadensis & $\mathrm{T}$ & - & - & - & $\mathrm{T}$ & - & $\mathrm{T}$ & $\mathrm{T}$ & $\mathrm{T}$ & $T$ & $T$ & $\mathrm{~T}$ \\
\hline Cryptantha pterocarya & 0.2 & - & $\mathrm{T}$ & - & 0.4 & - & 0.3 & 0.1 & 0.2 & 0.1 & $\mathrm{~T}$ & 0.5 \\
\hline Cuscuta denticulata & - & - & - & - & $\mathrm{T}$ & - & $\mathrm{T}$ & $\mathrm{T}$ & $\mathrm{T}$ & - & $T$ & - \\
\hline Dalea mollissima & - & - & - & - & - & - & - & - & - & - & - & - \\
\hline Delphinium parishii & - & - & - & - & - & - & - & - & $\mathrm{T}$ & - & - & - \\
\hline Descurainia pinnala & $=$ & - & $=$ & - & 0.8 & - & 0.2 & - & 0.4 & - & $\mathrm{T}$ & - \\
\hline Dichelostemma congestum & $\mathrm{T}$ & - & - & - & - & - & - & - & - & - & - & - \\
\hline Echinocactus polycephalus & - & - & - & - & - & - & - & - & - & - & - & - \\
\hline Echinocereus engelmannii & 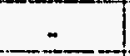 & - & - & - & - & - & - & - & - & - & - & - \\
\hline Elymus elymoides & - & - & - & - & - & - & - & - & - & - & - & - \\
\hline Elymus multisetus & - & - & - & - & - & - & - & - & - & - & - & - \\
\hline Encelia virginensis & - & - & - & - & - & - & - & - & - & $\mathrm{T}$ & - & - \\
\hline Ephedra nevadensis & 0.3 & - & 0.3 & $\therefore$ & 0.2 & - & 1.3 & 1.8 & 0.1 & 1.1 & 0.2 & 1.5 \\
\hline Ephedra viridis & $\ldots$ & - & $\therefore$ & - & - & - & - & $\ldots$ & - & - & - & - \\
\hline Eriastrum eremicum & - & - & - & - & - & - & $\mathrm{T}$ & $\mathrm{T}$ & - & - & - & - \\
\hline Eriastrum sparsiflorum & - & - & - & - & - & - & - & - & - & - & - & - \\
\hline Ericameria cooperi & - & - & - & $T$ & 0.2 & - & - & - & 0.4 & - & 1.6 & - \\
\hline Ericameria linearifolia & - & - & - & - & $-\cdot$ & - & - & - & - & - & - & $\therefore$ \\
\hline Eriogonum deflexum & - & - & $\mathrm{T}$ & - & - & - & - & - & - & - & - & - \\
\hline Eriogonum fasciculatum & - & - & - & - & - & - & - & $\mathrm{T}$ & - & $\mathrm{T}$ & - & $=$ \\
\hline Eriogonum inflalum & $\mathrm{T}$ & - & - & - & - & - & - & 0.2 & $=$ & 0.1 & - & $\mathrm{T}$ \\
\hline Eriogonum maculatum & - & - & - & - & - & - & $\mathrm{T}$ & - & - & $\mathrm{T}$ & 0.1 & - \\
\hline Eriogonum microthecum & - & - & - & - & - & - & - & - & - & - & - & - \\
\hline
\end{tabular}


APPENDIX E2 (continued)

\begin{tabular}{|c|c|c|c|c|c|c|c|c|c|c|c|c|}
\hline Species & LA1T & LA2C & LA2T & LA3C & LA3T & LA4C & LA4T & LA5C & LA5T & LA6C & LA7C & LATT \\
\hline Chrysothamnus teretifolius & - & $-\quad 1$ & - & - & - & - & - & - & - & - & - & - \\
\hline Eriogonum nidularium & - & - & - & - & $\mathrm{T}$ & - & - & $\mathrm{T}$ & - & - & - & - \\
\hline Erioneuron pulchellum & - & $=$ & - & - & $=$ & - & $=$ & $\mathrm{T}$ & - & - & - & - \\
\hline Eriophyllum pringlei & - & - & - & - & $\mathrm{T}$ & - & $\mathrm{T}$ & $\mathrm{T}$ & 0.2 & $T$ & $T$ & 0.1 \\
\hline Erodium cicutarium & - & $=$ & - & - & - & - & - & - & - & - & - & - \\
\hline Eschscholzia minutiflora & - & - & - & - & $\mathrm{T}$ & - & - & - & - & $\mathrm{T}$ & - & $\mathrm{T}$ \\
\hline Grayia spinosa & - & - & $\mathrm{T}$ & - & 0.1 & - & $\mathrm{T}$ & $T$ & 0.5 & - & 0.1 & 0.3 \\
\hline Gutierrezia sarothrae & - & - & - & - & - & - & - & - & - & - & - & - \\
\hline Hilaria jamesii & - & - & - & - & $\therefore$ & - & $=$ & - & $\therefore$ & - & - & - \\
\hline Hymenoclea salsola & - & - & - & - & - & - & - & - & $T$ & - & 0.1 & - \\
\hline Krameria erecta & $T$ & - & 2.0 & 0.2 & 0.6 & - & $\mathrm{T}$ & 0.5 & 0.4 & 1.0 & 0.4 & 1.2 \\
\hline Krascheninnikovia lanata & $T$ & 0.4 & 0.3 & $\mathrm{~T}$ & $\mathrm{~T}$ & 0.5 & $\mathrm{~T}$ & $\mathrm{~T}$ & $T$ & - & $\mathrm{T}$ & - \\
\hline Larrea tridentata & 2.5 & 1.5 & 1.0 & 1.4 & 1.9 & 1.2 & 2.6 & 1.4 & 1.9 & 0.5 & 1.4 & 0.9 \\
\hline Lepidium fremontii & - & $=1$ & - & - & - & - & - & - & - & $=$ & - & - \\
\hline Lepidium lasiocarpum & - & - & $\mathrm{T}$ & - & $\mathrm{T}$ & - & - & - & $=$ & 0.2 & - & $T$ \\
\hline Loeseliastrum schottii & - & - & - & - & - & - & $T$ & - & $\because$ & - & - & - \\
\hline Lomatium nevadense & $=$ & $=$ & $\therefore$ & - & $=$ & - & - & - & - & - & - & - \\
\hline Lotus humistratus & - & - & - & - & - & - & - & - & $=$ & - & - & - \\
\hline Lupinus concinmus & - & - & - & - & $\mathrm{T}$ & - & $\mathrm{T}$ & - & - & - & - & $\mathrm{T}$ \\
\hline Lupinus flavoculatus & $T$ & - & $\mathrm{T}$ & $\mathrm{T}$ & - & - & - & $\mathrm{T}$ & - & - & - & $T$ \\
\hline Lycium andersonii & $\mathrm{T}$ & - & 0.1 & - & 0.7 & - & 0.2 & 0.1 & 0.1 & 0.2 & 0.5 & 0.5 \\
\hline Lycium pallidum & $\mathrm{T}$ & - & 0.9 & - & 2.9 & $\mathrm{~T}$ & 0.6 & 1.1 & 2.1 & 0.6 & 0.8 & 0.5 \\
\hline Malacothrix glabrata & - & - & $\mathrm{T}$ & $-\quad$ & - & - & 0.2 & $T$ & $T$ & - & 0.2 & $=$ \\
\hline Menodora spinescens & 0.7 & 1.7 & 0.6 & 2.0 & 0.8 & 1.9 & - & 0.4 & 0.4 & 3.2 & 1.9 & 7.1 \\
\hline Mentzelia obscura & $T$ & $T$ & 0.1 & 0.1 & - & $T$ & $T$ & - & $T$ & - & $=-1$ & $T-1$ \\
\hline Mirabilis bigelovii & - & - & - & -.1 & - & - & - & - & $=$ & - & $=$ & $=$ \\
\hline Monopilon bellidiforme & - & - & - & - & - & - & $\mathrm{T}$ & - & $\mathrm{T}$ & - & $T$ & $\therefore$ \\
\hline Muhlenbergia porteri & - & - & - & - & - & - & $\because$ & - & - & - & - & \\
\hline Nama demissum & - & 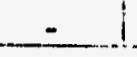 & - & - & - & - & - & - & - & $T$ & $=$ & \\
\hline
\end{tabular}


APPENDIX E2 (continued)

\begin{tabular}{|c|c|c|c|c|c|c|c|c|c|c|c|c|}
\hline $\begin{array}{r}\text { Species } \\
\end{array}$ & LA1T & LA2C & LA2T & $\mathbf{L A 3 C}$ & LA3T & LA4C & LA4T & LA5C & LAST & LA6C & LA7C & LA7T \\
\hline Chrysothammus teretifolius & - & - & - & - & - & - & - & - & - & - & - & - \\
\hline Opuntia basilaris & - & - & - & - & - & - & - & - & - & - & - & - \\
\hline Opuntia echinocarpa & - & 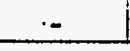 & $\mathrm{T}$ & - & $=$ & - & - & - & - & - & - & - \\
\hline Oryzopsis hymenoides & $\mathrm{T}$ & 0.3 & 0.4 & 0.4 & $\mathrm{~T}$ & 0.4 & $\mathrm{~T}$ & $\mathrm{~T}$ & $\mathrm{~T}$ & - & 0.1 & - \\
\hline Oxytheca perfoliata & - & - & - & - & $\mathrm{T}$ & - & - & $\mathrm{T}$ &. & $\mathrm{T}$ & - & $T$ \\
\hline Pectocarya platycarpa & - & - & - & - & 0.4 & - & $\mathrm{T}$ & 0.3 & $\mathrm{~T}$ & 1.6 & - & 0.7 \\
\hline Peclocarya setosa & - & - & - & - & 0.2 & - & - & - & $\mathrm{T}$ & $\mathrm{T}$ & - & $\mathrm{T}$ \\
\hline Phacelia crenulata & $=$ & $=$ & - & - & - & - & - & - & - & - & - & - \\
\hline Phacelia fremontii & - & $=$ & $=$ & - & - & - & - & $=$ & - & - & - & $\mathrm{T}$ \\
\hline Phacelia vallis-mortae & - & - & - & - & - & - & - & $=$ & - & - & - & - \\
\hline Phlox stansburyi & - & - & - & - & - & - & - & - & - & - & - & - \\
\hline Psorothamnus fremontii & - & - & - & - & $-\cdot$ & $\therefore$ & - & - & - & 0.1 & - & 0.3 \\
\hline Rafinesquia neomexicana & - & - & $\mathrm{T}$ & - & $\mathrm{T}$ & - & $\mathrm{T}$ & $\mathrm{T}$ & $\mathrm{T}$ & - & $=$ & $\mathrm{T}$ \\
\hline Salazaria mexicana & $=$ & - & - & - & $\therefore$ & - & - & $\mathrm{T}$ & - & $\mathrm{T}$ & - & - \\
\hline Salsola kali & 二 & - & $\mathrm{T}$ & - & - & - & $\mathrm{T}$ & - & $\mathrm{T}$ & - & $=$ & - \\
\hline Schismus arabicus & - & - & $\mathrm{T}$ & - & $\mathrm{T}$ & $\mathrm{T}$ & $\mathrm{T}$ & - & $\mathrm{T}$ & - & - & $\mathrm{T}$ \\
\hline Sclerocactus polyancistrus & $=$ & - & - & - & - & - & - & - & - & - & - & - \\
\hline Sisymbrium altissimum & 0.2 & 0.1 & 0.3 & $\mathrm{~T}$ & 0.2 & 0.2 & 0.2 & - & $\mathrm{T}$ & $=$ & 0.1 & $=$ \\
\hline Sphaeralcea ambigua & - & - & - & - & $=$ & - & - & - & - & - & - & - \\
\hline Stephanomeria parryi & - & $\mathrm{T}$ & $T$ & $T$ & - & - & $\mathrm{T}$ & - & - & - & $\mathrm{T}$ & - \\
\hline Stephanomeria pauciflora & $=$ & - & - & - & - & - & $\mathrm{T}$ & - & $\mathrm{T}$ & $\mathrm{T}$ & $=$ & - \\
\hline Stipa speciosa & - & - & $\mathrm{T}$ & - & $\mathrm{T}$ & - & - & - & - & $\mathrm{T}$ & $\mathrm{T}$ & $T$ \\
\hline Syntrichopappus fremontii & 二 & - & - & - & - & - & - & - & - & $=$ & - & - \\
\hline Tetradymia axillaris & - & - & - & $\cdots$ & - & - & - & - & - & - & $=$ & $\therefore$ \\
\hline Tetradymia glabrata & - & 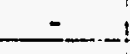 & - & - & - & - & - & - & - & & - & - \\
\hline Vulpia octoflora & -0.5 & 0.2 & $\mathrm{~T}$ & 1.1 & 0.8 & 1.0 & 0.3 & 0.1 & 0.7 & 0.3 & 0.4 & $\mathrm{~T}$ \\
\hline Xylorhiza tortifolia & - & - & - & - & $\mathrm{T}$ & - & $\mathrm{T}$ & - & $\mathrm{T}$ & $\therefore 0.1$ & $\therefore \ldots$ & - \\
\hline Yucca brevifolia & - & - & - & - & - & - & - & - & - & - & - & - \\
\hline
\end{tabular}

Yucca brevifolia 


\section{APPENDIX E3}

Average percent plant cover on 12 Ecological Study Plots in the Lycium-Grayia vegetation association at Yucca Mountain, Nevada, during 1989-1994. Species with less than $0.1 \%$ cover are indicated with a "T"; species not present are indicated with a "-."

\begin{tabular}{|c|c|c|c|c|c|c|c|c|c|c|c|c|c|}
\hline Species & LG1C & LG2C & LG2T & LG3C & LG3T & LG4C & LG4T & LG5C & LG5T & LG6C & LG6T & LG7C & LG7T \\
\hline Acamplopappus shockleyi & $\mathrm{T}$ & - & $\mathrm{T}$ & - & $\mathrm{T}$ & - & - & - & - & $\cdots$ & - & - & - \\
\hline Ambrosia dumosa & 0.9 & 0.4 & $\mathrm{~T}$ & 0.8 & - & 1.1 & 0.2 & 0.9 & 2.9 & 0.2 & 0.1 & 0.1 & 0.6 \\
\hline Amsinckia tessellata & $\mathrm{T}$ & $\mathrm{T}$ & 1.7 & $\mathrm{~T}$ & 0.1 & $T$ & $\mathrm{~T}$ & 0.1 & 0.2 & 0.4 & 0.2 & 0.4 & 0.2 \\
\hline Aristida purpurea & $=$ & - & - & - & $\mathrm{T}$ & - & - & $-\quad$ & - & - & $-\quad$ & 0.1 & - \\
\hline Artemisia spinescens & $\mathrm{T}$ & $=$ & - & - & - & - & - & - & - & - & - & - & - \\
\hline Artemisia tridentata & - & - & 1.1 & - & $\mathrm{T}$ & - & - & $\mathrm{T}$ & - & - & 0.4 & - & - \\
\hline Astragalus acutirostris & - & $=$ & - & - & $\mathrm{T}$ & $=$ & - & - & - & $=$ & - & - & - \\
\hline Astragalus layneae & - & $=$ & - & - & - & - & - & - & - & - & - & - & - \\
\hline Atriplex canescens & $T$ & - & 0.5 & $\mathrm{~T}$ & $\mathrm{~T}$ & 0.1 & - & 0.2 & - & 0.5 & $=$ & 0.1 & 0.3 \\
\hline Atriplex confertifolia & 1.1 & 0.5 & 0.3 & 0.5 & $\mathrm{~T}$ & 0.8 & 0.1 & 1.5 & 1.4 & 0.8 & 0.6 & 0.8 & 0.6 \\
\hline Atriplex polycarpa & - & - & $\mathrm{T}$ & - & - & - & - & - & - & - & - & - & - \\
\hline Brickellia microphylla & - & - & $T$ & - & - & - & - & - & - & 0.1 & $=$ & 0.1 & $\mathrm{~T}$ \\
\hline Bromus rubens & 5.2 & 7.4 & 7.2 & 5.0 & 4.1 & 4.7 & 4.6 & 3.6 & 3.9 & 4.6 & 6.3 & 3.3 & 6.4 \\
\hline Bromus tectorum & - & - & $\mathrm{T}$ & - & 0.3 & - & - & - & - & - & $\mathrm{T}$ & - & $-\quad \cdot$ \\
\hline Calochortus flexuosus & $=$ & $\therefore$ & - & $\mathrm{T}$ & - & $\mathrm{T}$ & $\mathrm{T}$ & - & - & - & - & - & - \\
\hline Camissonia brevipes & $=$ & $=$ & $\mathrm{T}$ & - & - & - & - & - & - & - & - & - & - \\
\hline Castilleja angustifolia & - & - & $\therefore$ & - & $\mathrm{T}$ & $\mathrm{T}$ & - & - & - & - & $\mathrm{T}$ & - & - \\
\hline Centrostegia thurberi & - & $=$ & $\therefore$ & $\mathrm{T}$ & - & - & - & - & $\mathrm{T}$ & - & $\therefore$ & - & - \\
\hline Chaenactis carphoclinia & - & $=$ & - & - & - & - & - & - & - & - & - & $=$ & - \\
\hline Chaenactis fremontii & - & - & $=$ & - & - & - & - & - & - & $=$ & - & $=$ & - \\
\hline Chaenactis macrantha & - & $=$ & - & - & - & - & - & - & - & $=$ & - & - & - \\
\hline Chaenactis stevioides & $\mathrm{T}$ & $=$ & $\mathrm{T}$ & $\mathrm{T}$ & $\mathrm{T}$ & $\mathrm{T}$ & $\mathrm{T}$ & - & - & $\mathrm{T}$ & $T^{\prime}$ & - & $=$ \\
\hline Chamaesyce albomarginata & - & - & $\mathrm{T}$ & - & - & - & - & - & 0.1 & - & - & - & - \\
\hline Chorizanthe brevicornu & $T$ & $=$ & $\mathrm{T}$ & $T$ & - & $T$ & $T$ & - & 0.2 & $\mathrm{~T}$ & $\mathrm{~T}$ & - & $T$ \\
\hline Chorizanthe rigida & - & - & - & - & - & - & - & - & - & $\therefore$ & $\because$ & - & $\therefore$ \\
\hline Chrysothamnus nauseosus & - & $=$ & 0.4 & - & 0.5 & - & - & $\mathrm{T}$ & 0.2 & $=$ & - & - & - \\
\hline
\end{tabular}


APPENDIX E3 (continued)

\begin{tabular}{|c|c|c|c|c|c|c|c|c|c|c|c|c|c|}
\hline Species & LG1C & LG2C & LG2T & LG3C & LG3T & LG4C & LG4T & LG5C & LG5T & LG6C & LG6T & LG7C & LG7T \\
\hline Chrysothamnus teretifolius & $\mathrm{T}$ & 0.6 & 0.8 & 0.4 & 0.1 & 0.1 & 0.5 & 0.5 & 0.1 & $\begin{array}{r}\cdot .3 \\
\end{array}$ & 0.5 & 0.8 & 0.2 \\
\hline Chrysothamnus viscidiflorus & 0.3 & 0.3 & 0.1 & $\mathrm{~T}$ & 0.6 & 0.3 & 0.4 & 0.1 & $-\quad$ & 0.2 & 0.2 & - & $\mathrm{T}$ \\
\hline Cirsium neomexicanum & - & $\mathrm{T}$ & - & - & $-\quad$ & - & - & - & - & - & - & - & - \\
\hline Coleogyne ramosissima & - & 0.2 & $\mathrm{~T}$ & $\mathrm{~T}$ & - & 0.2 & - & - & - & - & - & - & - \\
\hline Cryptantha circumscissa & $\mathrm{T}$ & - & - & $\mathrm{T}$ & - & $\mathrm{T}$ & $\mathrm{T}$ & $\mathrm{T}$ & - & - & $\mathrm{T}$ & - & $\mathrm{T}$ \\
\hline Cryptantha micrantha & - & $\mathrm{T}^{\cdot}$ & - & - & - & $\mathrm{T}$ & - & - & - & $\because$ & $\mathrm{T}$ & $\therefore$ & - \\
\hline Cryptantha nevadensis & $\mathrm{T}$ & 0.1 & - & 0.1 & 0.1 & $\mathrm{~T}$ & $\mathrm{~T}$ & - & $\mathrm{T}$ & - & $T$ & - & $\mathrm{T}$ \\
\hline Cryptantha pterocarya & 0.1 & 0.31 & $\mathrm{~T}$ & $T$ & 0.4 & 0.3 & 0.1 & 0.2 & $\mathrm{~T}$ & 0.1 & 0.2 & - & $\mathrm{T}$ \\
\hline Cuscuta denticulata & $-\quad 1$ & - & $=$ & - & -.1 & - & - & - & - & - & - & - & - \\
\hline Dalea mollissima & $=$ & - & - & - & - & - & - & - & - & - & - & - & - \\
\hline Delphinium parishii & $I$ & $\therefore$ & - & $\mathrm{T}$ & - & - & $\mathrm{T}$ & - & - & - & $T$ & - & - \\
\hline Descurainia pinnata ... & T & $=$ & $\mathrm{T}$ & - & $\mathrm{T}$ & $\mathrm{T}$ & $T$ & $\mathrm{~T}$ & $T$ & $\mathrm{~T}$ & - & - & - \\
\hline Dichelostemma congestum & - & $\therefore$ & - & - & - & - & - & - & - & - & - & - & - \\
\hline Echinocactus polycephalus & - & $\mathrm{T}$ & $\therefore$ & - & - & - & - & - & $\mathrm{T}$ & - & - & - & - \\
\hline Echinocereus engelmannii & $=$ & $=$ & - & $=$ & - & - & - & - & - & - & - & - & - \\
\hline Elymus elymoides & - & - & $\mathrm{T}$ & $\mathrm{T}$ & 0.1 & $\mathrm{~T}$ & $\mathrm{~T}$ & - & - & - & $\mathrm{T}$ & - & - \\
\hline Elymus multisetus & - & - & - & - & - & - & $\mathrm{T}$ & - & - & - & - & - & $\mathrm{T}$ \\
\hline Encelia virginensis & - & - & $T$ & - & $T$ & - & - & $-\quad$ & $\mathrm{T}$ & 0.8 & - & 0.5 & $\mathrm{~T}$ \\
\hline Ephedra nevadensis & 1.1 & 2.0 & 3.0 & .4 .2 & 1.3 & 2.0 & 3.1 & 2.0 & $\cdots 2.2$ & 0.9 & 2.8 & 0.8 & -3.3 \\
\hline Ephedra viridis & - & 0.4 & 0.7 & - & 0.3 & - & - & $-\cdots$ & - & 1.2 & 0.2 & 0.9 & .0 .2 \\
\hline Eriastrum eremicum & $\mathrm{T}$ & - & $\mathrm{T}$ & - & $\mathrm{T}$ & - & $T$ & - & $T$ & - & $\mathrm{T}$ & - & - \\
\hline Eriastrum sparsiflorum & - & $\therefore$ & $T$ & - & - & - & - & - & - & - & $\mathrm{T}$ & - & $\mathrm{T}$ \\
\hline Ericameria cooperi & 1.3 & 2.0 & 0.8 & 2.2 & 1.5 & 1.3 & 1.2 & 0.4 & 0.1 & 0.2 & 2.7 & 0.3 & 1.0 \\
\hline Ericameria linearifolia & $T$ & $T$ & 0.6 & - & 0.9 & - & $T$ & 0.1 & - & $\mathrm{T}$ & 0.1 & - & - \\
\hline Eriogonum deflexum & - & - & $\therefore-$ & $\mathrm{T}$ & - & - & - & - & - & $-\quad$ & $\cdots$ & $=$ & - \\
\hline Eriogonum fasciculatum & 0.1 & 0.9 & 1.7 & 0.9 & 4.0 & 1.1 & 0.9 & 3.4 & 0.3 & 3.7 & 1.0 & 2.4 & 0.9 \\
\hline Eriogonum inflatum & $\mathrm{I}$ & 0.2 & 0.1 & - & $T$ & $T$ & $T$ & 0.2 & 0.4 & - & $T$ & $\therefore$ & 0.2 \\
\hline Eriogonum maculatum & - & -1 & $=$ & - & - & - & - & $=$ & - & - & $T$ & - & $T$ \\
\hline Eriogonum microthecum & - & - & $T$ & - & 0.2 & $-\cdot$ & - & - & - & - & $\therefore$ & - & - \\
\hline
\end{tabular}




\section{APPENDIX E3 (continued)}

\begin{tabular}{|c|c|c|c|c|c|c|c|c|c|c|c|c|c|}
\hline Species & LG1C & LG2C & LG2T & LG3C & LG3T & LG4C & LG4T & LG5C & LG5T & LG6C & LG6T & LG7C & LG7T \\
\hline Eriogonum nidularium & $\mathrm{T}$ & - & $\mathrm{T}$ & 0.1 & $\mathrm{~T}$ & $T$ & 0.2 & - & $\mathrm{T}$ & - & 0.1 & - & $T$ \\
\hline Erioneuron pulchellum & 0.1 & - & - & $=$ & - & - & $-\quad 1$ & 0.2 & $\mathrm{~T}$ & - & - & - & - \\
\hline Eriophyllum pringlei & -1 & - & - & $=$ & - & - & $=$ & $-\quad 1$ & - & - & - & - & - \\
\hline Erodium cicutarium & - & $\mathrm{T}$ & - & - & - & - & $\mathrm{T}$ & - & - & - & - & - & - \\
\hline Eschscholzia minutiflora & - & $\mathrm{T}$ & $\mathrm{T}$ & - & - & - & - & - & - & - & - & - & - \\
\hline Grayia spinosa & 1.8 & 2.3 & 2.0 & 2.1 & 1.1 & 1.0 & 1.9 & 1.6 & 0.7 & 0.9 & 3.3 & 0.3 & 2.2 \\
\hline Gutierrezia sarothrae & 0.8 & 0.3 & 0.7 & $T$ & 0.2 & 0.4 & 0.8 & 0.2 & $\mathrm{~T}$ & 0.8 & 0.2 & 0.3 & $\mathrm{~T}$ \\
\hline Hilaria jamesii & 0.2 & 1.1 & $=$ & 0.6 & 2.7 & $\mathrm{~T}$ & 1.1 & - & - & - & 0.7 & - & 0.4 \\
\hline Hymenoclea salsola & 0.5 & $\mathrm{~T}$ & 0.3 & 1.1 & 1.2 & 0.4 & 2.3 & 1.3 & 1.2 & $T$ & 0.2 & - & 1.2 \\
\hline Krameria erecta & $\mathrm{T}$ & - & $\therefore$ & - & $\mathrm{T}$ & $T$ & - & - & - & - & - & - & - \\
\hline Krascheninnikovia lanala & 0.8 & 0.9 & 0.4 & $T$ & 0.2 & 0.2 & 0.5 & 0.2 & 0.2 & 0.1 & 0.4 & 0.1 & 0.5 \\
\hline Larrea tridentata & $\mathrm{T}$ & - & 0.1 & - & - & $\therefore$ & - & 0.2 & 1.1 & - & $\mathrm{T}$ & - & - \\
\hline Lepidium fremontii & - & $=$ & $=$ & - & - & $\mathrm{T}$ & - & - & - & - & - & - & - \\
\hline Lepidium lasiocarpum & - & $=$ & $=$ & - & $\mathrm{T}$ & - & - & 0.2 & 0.2 & - & $\therefore$ & - & - \\
\hline Loeseliastrum schottii & - & - & $=$ & - & - & - & - & - & - & - & - & - & - \\
\hline Lornatium neradense & - & $=$ & - & - & - & - & - & - & - & $=$ & - & - & - \\
\hline Lotus humistratus & - & - & $T$ & 0.1 & $T$ & 0.2 & - & - & $T$ & - & - & - & $\mathrm{T}$ \\
\hline Lupinus concinnus & - & $=$ & $\therefore$ & - & - & - & - & - & - & - & - & - & - \\
\hline Lupinus flavoculatus & $\mathrm{T}$ & - & -1 & $\mathrm{~T}$ & $T$ & $T$ & - & - & - & - & $\mathrm{T}$ & - & - \\
\hline Lycium andersonii & 2.1 & 2.0 & 0.8 & 2.8 & 0.7 & 2.9 & 2.6 & 0.6 & 1.8 & 0.4 & 1.0 & - & 2.1 \\
\hline Lycium pallidum & 0.1 & 0.2 & - & - & - & $\mathrm{T}$ & - & $\mathrm{T}$ & 0.7 & - & 0.2 & $=$ & 0.7 \\
\hline Malacothrix glabrata & $=$ & 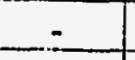 & - & $\mathrm{T}$ & - & $\mathrm{T}$ & $T$ & - & - & - & - & - & - \\
\hline Menodora spinescens & - & - & $=$ & 2.3 & - & 0.9 & $\mathrm{~T}$ & - & - & - & - & $=$ & - \\
\hline Mentzelia obscura & 0.1 & $\mathrm{~T}$ & $\mathrm{~T}$ & - & - & $\mathrm{T} \cdot$ & $\mathrm{T}$ & - & $\mathrm{T}$ & $\mathrm{T}$ & $\mathrm{T}$ & 0.4 & $=$ \\
\hline Mirabilis bigelovii & - & $\mathrm{T}$ & 0.2 & $=$ & $\mathrm{T}$ & $\mathrm{T}$ & - & $\mathrm{T}$ & - & - & $T$ & $=$ & $\mathrm{T}$ \\
\hline Monoptilon bellidiforme & - & - & - & - & - & - & $=$ & - & - & - & - & $=$ & - \\
\hline Muhlenbergia porteri & - & - & - & - & - & - & - & $=$ & - & $\mathrm{T}$ & - & $\therefore$ & - \\
\hline Nama demissum & - & - & - & - & - & - & - & - & - & - & $\therefore$ & - & $=$ \\
\hline Opuntia basilaris & - & - & - & - & $\mathrm{T}$ & $\mathrm{T}$ & $=$ & - & - & $\mathrm{T}$ & $=$ & - & \\
\hline
\end{tabular}


APPENDIX E3 (continued)

\begin{tabular}{|c|c|c|c|c|c|c|c|c|c|c|c|c|c|}
\hline Species & LG1C & LG2C. & LG2T & LG3C & LG3T & LG4C & LG4T & LG5C & LG5T & LG6C & LG6T & LG7C & LG7T \\
\hline Opuntia echinocarpa & - & - & - & - & $\cdot$ & - & - & - & - & - & - & - & - \\
\hline Oryzopsis hymenoides & $\mathrm{T}$ & - & $\mathrm{T}$ & - & - & - & - & - & - & - & - & - & $\mathrm{T}$ \\
\hline Oxylheca perfoliata & $\mathrm{T}$ & - & - & 0.1 & $T$ & 0.1 & $\mathrm{~T}$ & $\mathrm{~T}$ & - & - & $\mathrm{T}$ & - & $\mathrm{T}$ \\
\hline Pectocarya platycarpa & $\mathrm{T}$ & $\mathrm{T}$ & $\therefore$ & $\mathrm{T}$ & $\mathrm{T}$ & $\mathrm{T}$ & $\mathrm{T}$ & $\mathrm{T}$ & $\mathbf{T}$ & $\ldots$ & - & - & $\mathrm{T}$ \\
\hline Pectocarya setosa & - & - & - & - & $\mathrm{T}$ & $\mathrm{T}$ & $\mathrm{T}$ & $T$ & $\mathrm{~T}$ & - & $\mathrm{T}$ & - & $\mathrm{T}$ \\
\hline Phacelia crenulata & - & - & - & - & $\mathrm{T}$ & - & - & - & - & - & - & - & - \\
\hline Phacelia fremontii & 0.3 & $\mathrm{~T}$ & $\mathrm{~T}$ & 0.1 & - & 0.1 & $\mathrm{~T}$ & $\mathrm{~T}$ & $\mathrm{~T}$ & - & $\mathrm{T}$. & - & $\mathrm{T}$ \\
\hline Phacelia vallis-morlae & - & - & - & - & - & - & - & - & - & - & - & - & - \\
\hline Phlox stansburyi & - & - & - & - & $\mathrm{T}$ & - & - & - & - & - & - & - & - \\
\hline Psorothamnus fremontii & $=$ & $\mathrm{T}$ & - & - & - & $\therefore$ & - & $\mathrm{T}$ & - & - & - & - & - \\
\hline Rafinesquia neomexicana & - & $=$ & - & $\mathrm{T}$ & - & - & - & - & - & - & $\mathrm{T}$ & - & - \\
\hline Salazaria mexicana & $=$ & - & 1.4 & $\div$ & - & - & - & 0.1 & 0.2 & 1.3 & - & 1.0 & $\mathrm{~T}$ \\
\hline Salsola kali & - & - & 0.3 & $=$ & $\mathrm{T}$ & - & $\mathrm{T}$ & - & $\mathrm{T}$ & $-\quad \cdot$ & 0.1 & - & 0.1 \\
\hline Schismus arabicus & 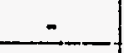 & - & - & - & - & - & - & - & - & - & - & - & - \\
\hline Sclerocactus polyancistrus & - & - & $=$ & - & - & - & - & 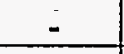 & - & $=$ & - & - & $\mathrm{T}$ \\
\hline Sisymbrium altissimum & - & $\therefore$ & 0.2 & $\mathrm{~T}$ & $\mathrm{~T}$ & $\mathrm{~T}$ & $\mathrm{~T}$ & - & $\mathrm{T}$ & $\mathrm{T}$ & $\mathrm{T}$ & - & - \\
\hline Sphaeralcea ambigua & 0.4 & 0.2 & - & 0.2 & 0.2 & 0.1 & $\mathrm{~T}$ & 0.2 & $\mathrm{~T}$ & $\therefore$ & 0.2 & - & 0.1 \\
\hline Stephanomeria parryi & - & - & - & - & $\mathrm{T}$ & - & - & $\mathrm{T}$ & $\mathrm{T}$ & - & $\mathrm{T}$. & - & - \\
\hline Stephanomeria pauciflora & $\mathrm{T}$ & 0.2 & $\mathrm{~T}$ & $\mathrm{~T}$ & - & - & $\mathrm{T}$ & 0.2 & $\mathrm{~T}$ & - & $\mathrm{T}$ & - & $\mathrm{T}$ \\
\hline Stipa speciosa & 0.5 & -0.2 & 0.5 & 1.1 & 0.2 & 1.0 & 0.4 & 0.2 & 0.2 & 0.3 & 0.3 & 0.5 & 0.4 \\
\hline Syntrichopappus fremontii & - & - & - & $\mathrm{T}$ & $\mathrm{T}$ & $\mathrm{T}$ & $\mathrm{T}$ & $\mathrm{T}$ & - & - & $\mathrm{T}$ & - & - \\
\hline Tetradymia axillaris & 0.2 & $\mathrm{~T}$ & $T$ & - & - & - & - & $\mathrm{T}$ & - & 0.1 & - & - & $=$ \\
\hline Tetradymia glabrata & $\mathrm{T}$ & - & $\mathrm{T}$ & - & - & - & $\mathrm{T}$ & $=$ & $=$ & - & $\mathrm{T}$ & - & - \\
\hline Vulpia octoflora & $\mathrm{T}$ & $T$ & - & $\mathrm{T}$ & $\mathrm{T}$ & 0.1 & $T$ & - & $\mathrm{T}$ & - & $\mathrm{T}$ & - & $=$ \\
\hline Xylorhiza tortifolia & - & $=$ & - & - & - & $=-$ & - & - & - & - & $\therefore$ & $=$ & $=$ \\
\hline Yucca brevifolia & - & - & - & - & - & - & - & - & - & - & - & - & - \\
\hline
\end{tabular}




\section{APPENDIX E4}

Average percent plant cover on 12 Ecological Study Plots in the Larrea-Lycium-Grayia vegetation association at Yucca Mountain, Nevada, during 1989-1994. Species with less than 0.1\% cover are indicated with a "T"; species not present are indicated with a "-."

\begin{tabular}{|c|c|c|c|c|c|c|c|c|c|c|c|c|}
\hline Species & LLGIT & LLG2T & LLG3C & LLG4C & LLG4T & LLG5C & LLG5T & LLG6T & LLG7C & LLG7T & LLG8C & LLG9C \\
\hline Acamplopappus shockleyi & $T$ & - & $\mathrm{T}$ & $\mathrm{T}$ & - & - & 0.1 & $T$ & - & - & $\mathrm{T}$ & - \\
\hline Ambrosia dumosa & 1.0 & 0.7 & 2.1 & 0.7 & 1.8 & 1.5 & 0.9 & 0.3 & 2.2 & 0.5 & 1.9 & 1.6 \\
\hline Amsinckia tessellata & 3.5 & 5.1 & 1.4 & 2.0 & 2.4 & 1.6 & 3.0 & 1.4 & 1.7 & 0.6 & 3.9 & 2.2 \\
\hline Aristida purpurea & - & - & - & - & - & - & - & - & - & $-\quad \cdot$ & - & - \\
\hline Artemisia spinescens & - & - & $\mathrm{T}$ & - & - & - & - & - & - & $=$ & - & - \\
\hline Artemisia tridentata & - & $=$ & - & - & - & - & - & - & - & - & - & - \\
\hline Astragalus acutirostris & - & - & $T$ & $\mathrm{~T}$ & - & - & - & - & - & $T$ & $T$ & - \\
\hline Astragalus layneae & - & - & - & - & - & - & - & $\mathrm{T}$ & - & - & - & $=$ \\
\hline Atriplex canescens & - & 0.2 & - & - & - & - & - & - & - & - & $T$ & 0.2 \\
\hline Atriplex confertifolia & - & - & - & 0.2 & - & - & - & $\mathrm{T}$ & $\mathrm{T}$ & - & - & $=$ \\
\hline Atriplex polycarpa & - & - & - & - & - & - & - & - & - & - & $=$ & - \\
\hline Brickellia microphylla & - & - & - & - & $\therefore$ & - & - & - & - & - & - & - \\
\hline Bromus rubens & 10.5 & .10 .5 & 6.1 & 6.4 & 4.9 & 7.6 & 9.0 & 4.2 & 6.1 & 7.9 & 10.7 & 6.0 \\
\hline Bromus tectorum & - & - & - & - & - & - & - & - &.- & - & - & - \\
\hline Calochortus flexuosus & - & - & $=$ & - & - & - & $T^{\prime}$ & - & - & - & - & - \\
\hline Camissonia brevipes & $=$ & $=$ & - & $\mathrm{T}$ & - & - & - & - & $\mathrm{T}$ & - & - & - \\
\hline Castilleja angustifolia & - & - & - & - & - & - & - & $=$ & - & - & - & - \\
\hline Centrostegia thurberi & - & - & - & - & $\mathrm{T}$ & - & $\mathrm{T}$ & $\mathrm{T}$ & - & 0.2 & - & - \\
\hline Chaenactis carphoclinia & - & $=$ & - & - & - & - & - & - & - & $=$ & - & - \\
\hline Chaenactis fremontii & $=$ & - & - & - & - & - & - & - & - & - & - & - \\
\hline Chaenactis macrantha & - & - & - & - & - & - & . & - & - & - & - & - \\
\hline Chaenactis stevioides & 0.1 & $\mathrm{~T}$ & $T$ & $\mathrm{~T}$ & 0.1 & $\mathrm{~T}$ & $T$ & 0.3 & $\mathrm{~T}$ & 0.5 & 0.6 & 0.2 \\
\hline Chamaesyce albomarginata & $T$ & 0.1 & - & - & 0.2 & - & - & $\mathrm{T}$ & - & $\therefore$ & - & - \\
\hline Chorizanthe brevicormu & $\mathrm{T}$ & $\mathrm{T}$ & $T$ & $\mathrm{~T}$ & $T$ & 0.1 & $T$ & $\mathrm{~T}$ & 0.1 & 0.1 & $T$ & $T$ \\
\hline Chorizanthe rigida & - & - & - & - & $=$ & - & - & $\mathrm{T}$ & $\mathrm{T}$ & - & - & $\therefore$ \\
\hline Chrysothamnus nauseosus & $=$ & $=$ & - & - & $=$ & - & - & $=$ & - & - & $\therefore$ & $\therefore$ \\
\hline
\end{tabular}


APPENDIX E4 (continued)

\begin{tabular}{|c|c|c|c|c|c|c|c|c|c|c|c|c|}
\hline Species & LLG1T & LLG2T & LLG3C & LLG4C & LLG4T & LLG5C & LLG5T & LLG6T & LLG7C & LLG7T & LLG8C & LLG9C \\
\hline Chrysothamnus teretifolius & - & $-\quad i$ & - & - & - & - & - & - & - & - & - & - \\
\hline Chrysothamnus viscidiflorus & - & - & $\mathrm{T}$ & - & - & - & - & - & - & - & - & - \\
\hline Cirsium neomexicanum & 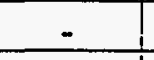 & - & - & - & - & - & - & - & - & - & - & - \\
\hline Coleogyne ramosissima & $\mathrm{T}$ & - & - & - & $\mathrm{T}$ & - & - & 0.2 & - & 1.4 & $\mathrm{~T}$ & - \\
\hline Cryptantha circumscissa & - & - & $\mathrm{T}$ & - & $\mathrm{T}$ & - & $\mathrm{T}$ & $\mathrm{T}$ & - & - & - & - \\
\hline Cryptantha micrantha & - & - & - & $\mathrm{T}$ & $\mathrm{T}$ & - & $\mathrm{T}$ & - & $-\cdot$ & - & - & - \\
\hline Cryplantha nevadensis & - & $\mathrm{T}$ & $T$ & $\mathrm{~T}$ & $\mathrm{~T}$ & $\mathrm{~T}$ & $\mathrm{~T}$ & 0.1 & $\mathrm{~T}$ & 0.2 & $\mathrm{~T}$ & - \\
\hline Cryptantha pterocarya & $\mathrm{T}$ & $0.2 !$ & 0.3 & 0.3 & 0.2 & 0.1 & $\mathrm{~T}$ & 0.5 & 0.2 & 0.8 & 0.3 & 0.2 \\
\hline Cuscuta denticulata & - & - & $=$ & - & - & - & - & - & - & - & - & - \\
\hline Dalea mollissima & - & $=$ & $=$ & - & - & - & - & - & $\mathrm{T}$ & - & - & - \\
\hline Delphinium parishii & - & $=1$ & - & - & - & $-\quad \cdot$ & - & - & - & - & - & - \\
\hline Descurainia pinnata & 0.7 & 0.5 & 0.3 & $\mathrm{~T}$ & 0.7 & 0.1 & 0.9 & 0.5 & 0.3 & 0.7 & 0.2 & - \\
\hline Dichelostemma congestum & - & $=$ & - & - & - & - & - & - & - & $\mathrm{T}$ & - & - \\
\hline Echinocactus polycephalus & - & - & - & - & - & $\therefore$ & - & - & - & - & - & - \\
\hline Echinocereus engelmannii & - & - & - & - & 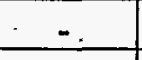 & $=$ & - & - & - & - & - & - \\
\hline Elymus elymoides & - & 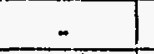 & - & - & - & - & - & - & - & - & - & - \\
\hline Elymus multisetus & - & - & - & - & - & - & - & - & - & - & $\mathrm{T}$ & - \\
\hline Encelia virginensis & $\mathrm{T}$ & - & - & - & 0.1 & - & - & 0.2 & $-\cdots$ & - & - & $\therefore$ \\
\hline Ephedra nevadensis & 2.3 & -0.8 & 2.3 & 2.6 & 4.0 & 1.9 & .1 .2 & 3.9 & 2.4 & 1.8 & 1.2 & 2.7 \\
\hline Ephedra viridis & - & $=$ & - & $\ldots$ & - & - & $-\quad$ & - & $\mathrm{T}$ & $-\quad$ & -1 & - \\
\hline Eriastrum eremicum & $\mathrm{T}$ & $T$ & $=$ & - & $T$ & - & - & $\mathrm{T}$ & - & $T$ & $\mathrm{~T}$ & - \\
\hline Eriastrum sparsiflorum & - & -1 & $\vdots$ & - & - &.$\quad \cdot$ & - & - & - & - & $=$ & - \\
\hline Ericameria cooperi & 0.6 & $0.5 !$ & 0.4 & 0.5 & 0.4 & 0.3 & 0.2 & 1.0 & $\mathrm{~T}$ & $\mathrm{~T}$ & $T$ & - \\
\hline Ericameria linearifolia & - & $-\ldots 1$ & - & $-\quad$. & $-\quad \cdot$ & - & - & - & - & - & - & - \\
\hline Eriogonum deflexum & - & - & $=$ & - & - & - & - & $\mathrm{T}$ & $\therefore$ & - & - & - \\
\hline Eriogonum fasciculatum & 0.2 & - & 0.1 & $\mathrm{~T}$ & 0.1 & 0.4 & - & 0.1 & - & $\mathrm{T}$ & 0.2 & 0.2 \\
\hline Eriogonum inflatum & 0.1 & $\mathrm{~T}$ & 0.2 & 0.2 & 0.2 & 0.1 & - & 0.1 & 0.7 & $=$ & 0.2 & 0.4 \\
\hline Eriogonum maculatum & - & $\mathrm{T}$ & - & - & - & - & - & $T$ & - & $\therefore$ &..- .1 & I \\
\hline Eriogonum microthecum & $=$ & - & - & - & - & - & - & - & $\therefore$ & - & $\because$ & - \\
\hline
\end{tabular}


APPENDIX E4 (continued)

\begin{tabular}{|c|c|c|c|c|c|c|c|c|c|c|c|c|}
\hline Species & LLG1T & LLG2T & LLG3C & LLG4C & LLG4T & LLG5C & LLG5T & LLG6T & LLG7C & LLG7T & LLG8C & LLG9C \\
\hline Eriogonum nidularium & $\mathrm{T}$ & $-\quad \vdots$ & - & - & - & - & - & $\mathrm{T}$ & $\mathrm{T}$ & - & - & - \\
\hline Erioneuron pulchellum & - & $=$ & - & $\mathrm{T}$ & $\mathrm{T}$ & $T$ & - & - & 0.1 & $=$ & - & $T$ \\
\hline Eriophyllum pringlei & - & - & - & - & - & - & $=$ & $T$ & - & $\mathrm{T}$ & - & - \\
\hline Erodium cicularium & $\mathrm{T}$ & 1 & $\mathrm{~T}$ & $\mathrm{~T}$ & - & - & - & 0.1 & - & - & $=$ & - \\
\hline Eschscholzia mimutiflora & $T$ & 0.2 & $\mathrm{~T}$ & $T$ & $T$ & - & - & - & $\mathrm{T}$ & - & $\mathrm{T}$ & - \\
\hline Grayia spinosa & 0.6 & $\mathrm{~T}$ & 0.7 & 0.2 & 0.3 & 0.4 & 0.4 & $\mathrm{~T}$ & $\mathrm{~T}$ & $=$ & 0.4 & $\mathrm{~T}$ \\
\hline Gutierrezia sarothrae & - & - & - & - & - & - & $-\quad$ & - & - & - & - & - \\
\hline Hilaria jamesii & - & - & - & - & - & - & - & $=$ & - & - & - & - \\
\hline Hymenoclea salsola & 1.3 & $0.9 i$ & $\underline{0.2}$ & $\mathrm{~T}$ & 0.1 & - & 2.0 & 1.6 & - & 0.7 & 0.6 & 0.1 \\
\hline Krameria erecta & 0.2 & $=$ & 2.6 & 2.2 & 2.0 & 2.3 & - & 1.1 & 2.2 & 0.3 & $\mathrm{~T}$ & 2.7 \\
\hline Krascheninnikovia Ianata & $\mathrm{T}$ & $\mathrm{T}$ & 0.2 & 0.2 & $\mathrm{~T}$ & 0.3 & $\mathrm{~T}$ & $\mathrm{~T}$ & $\mathrm{~T}$ & $\mathrm{~T}$ & 0.2 & - \\
\hline Larrea tridentala & 5.1 & $3.5 i$ & 1.4 & 2.8 & 2.5 & 1.9 & 5.1 & 2.2 & 3.5 & 2.2 & 4.6 & 2.1 \\
\hline Lepidium fremontii & - & - & - & - & $\mathrm{T}$ & - & - & - & - & - & - & - \\
\hline Lepidium lasiocarpu!n! & $\mathrm{T}$ & $\mathrm{T}$ & $\mathrm{T}$ & 0.3 & 0.3 & 0.3 & $\mathrm{~T}$ & 0.2 & 0.1 & $\mathrm{~T}$ & - & $\mathrm{T}$ \\
\hline Loeseliastrum schollii & - & - & $=$ & - & - & - & - & - & - & - & $=$ & - \\
\hline Lomatium neradense & - & - & - & - & - & - & - & $=$ & - & - & - & - \\
\hline Lotus humistratus & 0.2 & 0.5 & 0.4 & 0.1 & 0.3 & 0.2 & $\mathrm{~T}$ & $\mathrm{~T}$ & $\mathrm{~T}$ & 0.2 & 0.6 & 0.1 \\
\hline Lupinus concimmus & - & - & $T$ & - & $=$ & - & - & - & - & - & - & - \\
\hline Lupinus flavoculatus & - & - & $T$ & $\mathbf{T}$ & $\mathrm{T}$ & - & - & - & - & $\mathrm{T}$ & - & - \\
\hline Lycium andersonii & 1.1 & $\mathrm{~T}$ & 1.6 & 0.3 & 1.0 & 1.0 & 0.8 & 0.3 & 0.5 & 0.5 & 0.4 & 0.3 \\
\hline Lycium pallidum & - & - & 1.1 & 0.4 & - & 0.4 & $T$ & $\mathrm{~T}$ & 0.6 & - & - & 0.2 \\
\hline Malacothrix glabrata & - & $=$ & $T$ & $\mathrm{~T}$ & $\mathrm{~T}$ & $\mathrm{~T}$ & - & 0.1 & $\mathrm{~T}$ & 0.3 & $\mathrm{~T}$ & 0.2 \\
\hline Menodora spinescens & - & $-\quad 1$ & $\mathrm{~T}$ & - & 0.2 & - & 0.5 & 0.3 & - & 1.8 & - & 1.1 \\
\hline Mentzelia obscura & $\mathrm{T}$ & 0.5 & $T$ & 0.2 & 0.1 & 0.4 & $\mathrm{~T}$ & 0.6 & 0.5 & 0.2 & 1.2 & 1.0 \\
\hline Mirabilis bigelovii & - & - & $\mathrm{T}$ & - & $T$ & - & - & $\mathrm{T}$ & $\mathrm{T}$ & - & $-\ldots$ & - \\
\hline Monoptilon bellidiforme & $=$ & $=$ & - & $\mathrm{T}$ & $=$ & - & - & $\mathrm{T}$ & - & $=$ & $=$ & - \\
\hline Muhlenbergia porleri & $=$ & - & - & - & - & - & - & - & - & - & $\therefore$ & $=$ \\
\hline Nama demissum & - & $=$ & $\therefore$ & - & - & - & - & - & - & $=$ & - & - \\
\hline Opuntia basilaris & - & $\therefore$ & - & - & $T$ & $T$ & - & - & - & - & - & - \\
\hline
\end{tabular}


APPENDIX E4 (continued)

\begin{tabular}{|c|c|c|c|c|c|c|c|c|c|c|c|c|}
\hline Species & LLGIT & LLG2T i & LLG3C & LLG4C & LLG4T & LLG5C & LLG5T & LLG6T & LLG7C & LLG7T & LLG8C & LLG9C \\
\hline Ópuntia echinocarpa & - & -1 & - & - & - & - & - & $\mathrm{T}$ & $\therefore$ & - & - & - \\
\hline Oryzopsis hymenoides & - & - & - & - & - & $\mathrm{T}$ & - & $\mathrm{T}$ & - & - & - & - \\
\hline Oxytheca perfoliata & - & - & - & - & -1 & - & - & $T$ & $\mathrm{~T}$ & 0.2 & - & $T$ \\
\hline Peciocarya platycarpa & $T$ & $T$ & $T$ & 0.1 & 0.3 & $\mathrm{~T}$ & $T$ & 0.2 & $\mathrm{~T}$ & 0.2 & $T$ & - \\
\hline Pectocarya setosa & - & $T$ & - & $\mathrm{T}$ & 0.1 & $\mathrm{~T}$ & - & 0.2 & - & $T$ & - & $\mathrm{T}$ \\
\hline Phacelia crenulata & - & - & - & - & - & - & - & $-\quad$ & $\ldots$ & - & - & - \\
\hline Phacelia fremontii & $\mathrm{T}$ & $T$ & $\mathrm{~T}$ & - & $\mathrm{T}$ & $\mathrm{T}$ & $T$ & - & 0.1 & $\mathrm{~T}$ & $T$ & - \\
\hline Phacelia vallis-mortae & - & - & - & - & - & - & - & - & - & - & - & - \\
\hline Phlox stansburyi & - & $=$ & $\therefore$ & - & - & - & - & - & - & - & - & - \\
\hline Psorothamnus fremontii & $\therefore$ & $=$ & $=$ & - & - & - & - & - & - & 0.1 & - & - \\
\hline Rafinesquia neomexicana & $-\quad 1$ & -1 & - & $-\cdots$ & $T$ & - & - & $\mathrm{T}$ & - & $\mathrm{T}$ & - & $T$ \\
\hline Salazaria mexicana & 0.6 & 0.7 & 0.5 & 0.8 & 0.3 & 0.2 & $T$ & 0.4 & $T$ & $=$ & $T$ & - \\
\hline Salsola kali & $-\quad$ & I & $=$ & - & $\mathrm{T}$ & - & - & - & - & $T$ & - & - \\
\hline Schismus arabicus & $T$ & - & - & - & $T$ & - & - & - & - & - & - & - \\
\hline Sclerocactus polyancisirus & $=$ & $=$ & - & - & - & - & - & - & - & - & - & - \\
\hline Sisymbrium altissimum & $T$ & $\mathrm{~T}$ & $\mathrm{~T}$ & - & $\mathrm{T}$ & 0.1 & - & $\mathrm{T}$ & - & 0.1 & - & - \\
\hline Sphaeralcea ambigua & - & - & - & - & $\mathrm{T}$ & $\mathrm{T}$ & $\mathrm{T}$ & - & - & - & - & - \\
\hline Stephanomeria parryi & - & - & - & - & $T$ & - & $\therefore$ & - & - & 0.1 & $=$ & $\div$ \\
\hline Stephanomeria pauciflora & $T$ & - & - & $T$ & $T$ & - & - & $T$ & $T$ & - & - & $T$ \\
\hline Stipa speciosa & $T$ & $\mathrm{~T}$ & -0.1 & 0.1 & $T$ & 0.1 & $\mathrm{~T}$ & $T$ & $\mathrm{~T}$ & $\mathrm{~T}$ & 0.1 & T. \\
\hline Syntrichopappus fiemontii & $\therefore$ & - & - & - & - & - & - & - & - & - & $-\quad 1$ & - \\
\hline Tetradymia axillaris & - & $=$ & - & - & - & - & 0.1 & - & - & - & - & - \\
\hline Tetradymia glabrala & - & - & - & - & - & - & $\mathrm{T}$ & $\therefore$ & - & - & $=$ & - \\
\hline Vulpia octoflora & - & $\mathrm{T}$ & $T$ & $I$ & 0.1 & - & $\mathrm{T}$ & $T$ & 0.2 & $T$ & $\therefore$ & 0.3 \\
\hline Xylorhiza tortifolia & - &.- & $T$ & - & $-\quad$ & $=$ & - & - & - & - & & - \\
\hline Yucca brevifolia & - & - & $\therefore$ & - & - & - & - & - & - & - & $=$ & - \\
\hline
\end{tabular}




\section{APPENDIX F}

Checklist of Vascular Plants Observed in the Yucca Mountain, Nevada, Area During the Site Characterization Effects Program. 


\section{APPENDIX F}

Checklist of vascular plants observed in the Yucca Mountain, Nevada, area during the Site Characterization Effects Program, from 1989 to 1994 . $A=$ annual, $A S=$ summer annual, $A W=$ winter annual, $B=$ biennial, $P=$ perennial, $F=$ forb, $G=g r a s s, S=$ shrub, and $\mathrm{T}=$ tree. Naming conventions follow Kartesz and Pankhurst (1994).

\begin{tabular}{|c|c|c|c|c|}
\hline \begin{tabular}{|r} 
Scientific Name \\
\end{tabular} & Common Name & Family & Lifeform & Code \\
\hline Acamptopappus shockleyi Gray. & Shockley goldenhead & Asteraceae & PS & ACSH \\
\hline Amaranthus fimbriatus (Torr.) Benth. ex S. Wats. & fringed amaranth & Amaranthaceae & AF & AMFI \\
\hline Ambrosia acanthicarpa Hook. & sand bursage & Asteraceae & AF & AMAC \\
\hline Ambrosia dumosa (Gray) Payne & white bursage & Asteraceae & PS & AMDU \\
\hline Amphipappus fremontii Torr. \& Gray & Fremont chaffbush & Asteraceae & PS & AMFR \\
\hline Amsinckia tessellata Gray & common fiddleneck & Boraginaceae & AWF & AMTE \\
\hline Androstephium breviflorum S. Wats. & smallflower androstephium & Amaryllidaceae & PF & ANBR \\
\hline Anisocoma acaulis Torr. \& Gray & scalebud & Asteraceae & AWF & ANAC \\
\hline Arabis pulchra M. E. Jones & prince rockcress & Brassicaceae & $\mathrm{PF}$ & ARP1 \\
\hline Argemone munita Dur. \& Hilg. & chicalote & Papaveraceae & PF & ARMU \\
\hline Aristida purpurea Nutt. & purple threeawn & Poaceae & $\mathrm{PG}$ & ARPU; ARFE, or ARLO \\
\hline Artemisia ludoviciana Nutt. & western mugwort & Asteraceae & PF & ARLU \\
\hline Artemisia spinescens D. C. Eat. & bud sagebrush & Asteraceae & PS & ARSP \\
\hline Artemisia tridentata Nutt. & big sagebrush & Asteraceae & PS & ARTR \\
\hline Astragalus acutirostris S. Wats. & sharpkeal milkvetch & Fabaceae & AWF & ASAC \\
\hline Astragalus didimocarpus Hook. \& Arn. & twoseed milkvetch & Fabaceae & AWF & ASDI \\
\hline Astragalus layneae Greene & Layne milkvetch & Fabaceae & $\mathrm{PF}$ & ASLA \\
\hline Astragalus lentiginosus Dougl. ex Hook. & freckled milkvetch & Fabaceae & $\mathrm{PF}$ & ASLE \\
\hline Atriplex canescens (Pursh) Nutt. & fourwing saltbush & Chenopodiaceae & PS & ATCA \\
\hline Atriplex confertifolia (Torr. \& Frem.) S. Wats. & shadscale & Chenopodiaceae & PS & ATCO \\
\hline Atriplex polycarpa (Torr.) S. Wats. & desert saltbush & Chenopodiaceae & PS & ATPO \\
\hline Baileya multiradiala Harvey \& Gray ex Gray & desert marigold & Asteraceae & PF & BAMU \\
\hline Baileya pleniradiata Harvey \& Gray ex Gray & woolly marigold & Asteraceae & AWF & BAPL \\
\hline Bouteloua barbala Lag. & sixweeks grama & Poaceae & $\mathrm{ASG}$ & $\mathrm{BOBA}$ \\
\hline
\end{tabular}


APPENDIX F (continued)

\begin{tabular}{|c|c|c|c|c|}
\hline Scientific Name & Common Name & Family & Lifeform & Code \\
\hline Brickellia microphylla (Nutt.) Gray & littleleaf brickellbush & Asteraceae & PS & BRWA \\
\hline Bromus rubens $\mathrm{L}$. & red brome & Poaceae & AWF & BRRU \\
\hline Bromus tectorum L. & cheatgrass & Poaceae & AWF & BRTE \\
\hline Calochortus flexuosus S. Wats. & straggling mariposa & Liliaceae & PF & CAFL \\
\hline Calycoseris parryi Gray & yellow tackstem & Asteraceae & AWF & CAPA \\
\hline Calycoseris wrightii Gray & white tackstem & Asteraceae & AWF & CAWR \\
\hline Camissonia boothii (Dougl. ex Lehin) Raven & Booth primrose & Onagraceae & AWF & $\mathrm{CABO}$ \\
\hline Camissonia brevipes (Gray) Raven & desert primrose & Onagraceae & AWF & CABR \\
\hline Camissonia heterochroma (S. Wats.) Raven & Shockley primrose & Onäraceae & $\mathrm{AF}$ & CAHE \\
\hline Camissonia kernensis (Munz) Raven & Kern County eveningprimrose & Onagraceae & AWF & CAKE \\
\hline Castilleja angustifolia (Nutt.) G. Don & desert Indian-paintbrush & Scrophulariaceae & PF & $\mathrm{CACH}$ \\
\hline Centrostegia thurberi Gray ex Benth. & spine flower & Polygonaceae & AWF & $\mathrm{CHTH}$ \\
\hline Chaenactis carphoclinia Gray & pebble pincushion & Asteraceae & AWF & $\mathrm{CHCA}$ \\
\hline Chaenactis fremontii Gray & Fremont pincushion & Asteraceae & AWF & CHFR \\
\hline Chaenactis macrantha D. C. Eat. & largeflower pincushion & Asteraceae & AWF & CHMA \\
\hline Chaenactis stevioides Hook. \& Arn. & broadflower pincushion & Asteraceae & AWF & CHST $^{*}$ \\
\hline Chamaesyce albomarginata (Torr. \& Gray) Small & rattlesnake weed & Euphorbiaceae & $\mathrm{PF}$ & EUAL \\
\hline Chamaesyce micromera (Boiss.) Woot. \& Standl. & desert spurge & Euphorbiaceae & ASF & EUMI. \\
\hline Chamaesyce setiloba (Engelm. ex Torr.) Millsp. ex Parish & Yuma spurge & Euphorbiaceae & ASF & EUSE \\
\hline Chorizanthe brevicornu Torr. & brittle chorizanthe & Polygonaceae & AWF & CHBR \\
\hline Chorizanthe rigida (Torr.) Torr. \& Gray & spiny herb & Polygonaceae & AWF & CHRI \\
\hline Chorizanthe watsonii Torr. \& Gray & Watson chorizanthe & Polygonaceae & AWF & CHWA \\
\hline Chrysothamnus nauseosus (Pallas ex Pursh) Britt. & rubber rabbitbrush & Asteraceae & PS & CHNA \\
\hline Chrysothamnus paniculatus (Gray) Hall & punctate rabbitbrush & Asteraceae & PS & CHPA \\
\hline Chrysothammus teretifolius (Dir. \& Hilg.) Hall & needleleaf rabbitbrush & Asteraceae & PS & CHTE \\
\hline Chrysothammus riscidiflorus (Hook.) Nutt. & stickyleaf rabbitbrush & Asteraceae & PS & $\mathrm{CHVI}^{\circ}$ \\
\hline Cirsium neomexicanum Gray & New Mexico thistle & Asteraceae & $\mathrm{BF}$ & CINE \\
\hline Claytonia perfoliata Donn ex Willd. & miners lettuce & Portulacaceae & AF & MOPE \\
\hline Coleogyne ramosissima Torr. & blackbrush & Rosaceae & PS & CORA \\
\hline
\end{tabular}


APPENDIX F (continued)

\begin{tabular}{|c|c|c|c|c|}
\hline Scientific Name & Common Name & Family & Lifeform & Code \\
\hline Cryptantha angusiffolia (Torr.) Greene & creasotebush cryptantha & Boraginaceae & AWF & CRAN \\
\hline Cryplantha circumscissa (Hook. \& Am.) 1. M. Johnston & cushion cryptantha & Boraginaceae & AWF & CRCI \\
\hline Crypiantha micrantha (Torr.) I. M. Jonhston & redroot cryptantha & Boraginaceae & AWF & CRMI \\
\hline Cryptantha nevadensis A. Nels. \& Kennedy & Nevada cryptantha & Boraginaceae & AWF & CRNE \\
\hline Cryptantha pterocarya (Torr.) Greene & wingnut cryptantha & Boraginaceae & AWF & CRPT \\
\hline Cuscuta denticulata Engelm. & desert dodder & Cuscutaceae & PF & CUDE or CUNE \\
\hline Dalea mollissima (Rydb.) Munz & silky prairie-clover & Fabaceae & PF & DAMO \\
\hline Datura wrightii Regel & sacred datura & Solanaceae & PF & DAME \\
\hline Delphinium parishii Gray & Parish larkspur & Ranunculaceae & $\mathrm{PF}$ & DEPA \\
\hline Descurainia pinnata (Walt.) Britt. & pinnate tansymustard & Brassicaceae & AWF & DEPI \\
\hline Dichelostemma conges!um (Sin.) Kunth & bluedicks & Amaryllidaceae & PF & DIPU \\
\hline Echinocactus polycephalus Engelm. \& Bigelow & cottontop cactus & Cactaceae & $\mathrm{PF}$ & ECPO \\
\hline Echinocereus engelmannii (Parry ex Engelm.) Lem. & saint cactus & Cactaceae & PF & ECEN \\
\hline Elymus elymoides (Raf.) Swezey & mountain squirreltail-grass & Poaceae & PG & SIHY \\
\hline Elymus multiselus M. E. Jones & big squirreltail-grass & Poaceae & $\mathrm{PG}$ & SIJU \\
\hline Encelia virginensis A. Nels. & Virgin River encelia & Asteraceae & PS & ENVI \\
\hline Ephedra nevadensis S. Wats. & Nevada ephedra & Ephedraceae & PS & EPNE \\
\hline Ephedra viridis Coville & green ephedra & Ephedraceae & PS & EPVI . \\
\hline Eriastrum eremicum (Jepson) Mason & desert eriastrum & Polemoniaceae & AWF & ERER \\
\hline Eriastrum sparsiflorum (Eastw.) Mason & fewflower eriastrum & Polemoniaceae & $\mathrm{AF}$ & ERSP \\
\hline Ericameria cooperi (Gray) Hall & Cooper goldenbush & Asteraceae & PS & $\mathrm{HACO}$ \\
\hline Ericameria linearifolia (DC.) Urbatsch \& Wussow & narrowleaf goldenweed & Asteraceae & PS & $\mathrm{HALI}$ \\
\hline Eriogonum deflexum Torr. & skeleton weed & Polygonaceae & AWF & ERDE \\
\hline Eriogonum fasciculatum Benth. & California buckwheat & Polygonaceae & PS & ERFA \\
\hline Eriogonum infla!ım Torr. \& Frem. & desert trumpet & Polygonaceae & $P F$ & ERI1 or ERIN \\
\hline Eriogonum insigne S. Wats. & exalted buckwheat & Polygonaceae & $\mathrm{AF}$. & ERI2 \\
\hline riogonum maculatum Heller & spotted buckwheat & Polygonaceae & AWF & ERMA \\
\hline riogomum microthectm Nutt. & Great Basin buckwheat & Polygonaceae & PS & ERMI \\
\hline riogonum nidularium Coville & birdnest buckwheat & Polygonaceae & AWF & ERNI \\
\hline
\end{tabular}


APPENDIX F (continued)

\begin{tabular}{|c|c|c|c|c|}
\hline Scientific Name & Common Name & Family & Lifeform & Code \\
\hline Eriogonum reniforme Torr. \& Frem. & kidneyleaf buckwheat & Polygonaceae & AWF & ERRE \\
\hline Erioneuron pulchellum (Kunth) Tateoka & fluffgrass & Poaceae & PG & ERPU் \\
\hline Eriophyllum pringlei Gray & Pringle eriophyllum & Asteraceae & AWF & ERPR \\
\hline Erodium cicutarium (L.) L'Her. ex Ait. & redstem filaree & Geraniaceae & AWF & ERCI \\
\hline Eschscholzia glyprosperma Greene & Mojave poppy & Papaveraceae & AWF & ESGL \\
\hline Eschscholzia minutiflora S. Wats. & pygmy poppy & Papaveraceae & AWF & ESMI \\
\hline Gilia cana (M. E. Jones) Heller & desert gilia & Polemoniaceae & AWF & GICA \\
\hline Gilia leptomeria Gray & Great Basin gilia & Polemoniaceae & AWF & GILE \\
\hline Gilia opthalmoides Brand & eyelike gilia & Polemoniaceae & AWF & GIOP \\
\hline Gilia scopulorum M. E. Jones & rock gilia & Polemoniaceae & AWF & GISC \\
\hline Gilia transmontana (Mason \& A. Grant) A. \& V. Grant) & transmontane gilia & Polemoniaceae & AWF & GITR \\
\hline Grayia spinosa (Hook.) Moq. & hopsage & Chenopodiaceae & PS & GRSP \\
\hline Gutierrezia microcephala (DC.) Gray & smallhead matchweed & Asteraceae & PS & GUMI \\
\hline Gutierrezia sarothrae (Pursh) Britt. \& Rusby & common snakeweed & Asteraceae & PS & GUSA \\
\hline Halogeton glomeratus (Bieb.) C. A. Mey. & halogeton & Chenopodiaceae & AF & HAGL \\
\hline Hilaria jamesii (Torr.) Benth. & galleta grass & Poaceae & PG & HIJA \\
\hline Hymenoclea salsola Torr. \& Gray ex Gray & white burrobrush & Asteraceae ${ }^{\circ}$ & PS & HYSA \\
\hline Krameria erecra Willd. ex J. A. Schultes & littleleaf ratany & Krameriaceae & PS & KRPA \\
\hline Krascheninnikovia lanala (Pursh) Guldenstaedt & winterfat & Chenopodiaceae & PS & CELA \\
\hline Langloisia selosissima (Torr. \& Gray ex Torr.) Greene & bristly langlosia & Polemoniaceae & AWF & LASE \\
\hline Larrea tridentata (Sesse \& Moc. ex DC.) Coville & creosotebush & Zygophyllaceae & PS & LATR \\
\hline Lepidium fiemontii S. Wats. & desert peppergrass & Brassicaceae & $\mathrm{PF}$ & LEFR \\
\hline Lepidium lasiocarpum Nutt. & hairypod peppergrass & Brassicaceae & AWF & LELA \\
\hline Leptodactylon pungens (Torr.) Torr. ex Nutt. & granite gilia & Polemoniaceae & PS- & LEPU \\
\hline Linanthus demissus (Gray) Greene & desert linanthus & Polemoniaceae & AWF & LIDE \\
\hline Linanthus dichotomus Benth. & evening snow & Polemoniaceae & AWF & LIDI \\
\hline Linanthus jonesii (Gray) Greene & Jones linanthus & Polemoniaceae & AWF & LIJO \\
\hline Loeseliastrum schottii (Torr.) Timbrook & Schott langloisia & Polemoniaceae & AWF & LASC \\
\hline Lomatium neradense (S. Wats.) Coult. \& Rose & Nevada wildlovage. & Apiaceae & $\mathrm{PF}$ & LONE \\
\hline
\end{tabular}


APPENDIX F (continued)

\begin{tabular}{|c|c|c|c|c|}
\hline Scientific Name & Common Name & Family & Lifeform & Code \\
\hline Lotus humistratus Greene & Low trefoil & Fabaceae & AWF & LOHU \\
\hline Lupinus concinmus J. G. Agardh & elegant lupine & Fabaceae & AWF & LUCO \\
\hline Lupinus flavoculatus Heller & yelloweye lupine & Fabaceae & AWF & LUFL \\
\hline Lycium andersonii Gray & Anderson desert thorn & Solanaceae & PS & LYAN \\
\hline Lycium pallidum Miers & rabbit thorn & Solanaceae & PS & LYPA \\
\hline Machaeranthera canescens (Pursh) Gray & hoary tansyaster & Asteraceae & $\mathrm{BF}$ & MACA \\
\hline Malacothrix coulteri Harvey \& Gray & snake head & Asteraceae & AWF & MACO \\
\hline Malacothrix glabrata (D. C. Eat. ex Gray) Gray & desert dandelion & Asteraceae & AWF & MAGL \\
\hline Malacothrix sonchoides (Nutt.) Torr. \& Gray & sowthistle malacothrix & Asteraceae & AWF & MASO \\
\hline Mammillaria letrancistra Engelm. & fishhook cactus & Cactaceae & PF & MATE \\
\hline Menodora spinescens Gray & spiny menodora & Oleaceae & PS & MESP \\
\hline Mentzelia albicaulis (Doug. ex Hook.) Dougl. Torr. \& Gray & whitestem stickleaf . & Loasaceae & AWF & MEAL \\
\hline Mentzelia obscura H. J. Thompson \& Roberts & silverstem stickleaf & Loasaceae & AWF & MEOB \\
\hline Mirabilis bigelovii Gray & desert four-o'clock & Nyctaginaceae & PF & MIBI \\
\hline Monoptilon bellidiforme Torr. and Gray ex Gray & desert star & Asteraceae & AWF & MOBE \\
\hline Muhlenbergia porteri Scribn. ex Beal & bush muhly & Poaceae & $\mathrm{PG}$ & MUPO \\
\hline Nama demissum Gray & purplemat & Hydrophyllaceae & AWF & NADE \\
\hline Nama pusillum J. G. \& S. A. Lemmon ex Gray & smallleaf nama & Hydrophyllaceae & AWF & NAPU \\
\hline Nemacladus rubescens Greene & desert threadplant & Campanulaceae & AWF & NERU \\
\hline Nicotiana trigonophylla Dunal. & desert tobacco & Solanaceae & PF & NITR \\
\hline Oenothera cespitosa Nutt. & cespitose eveningprimrose & Onagraceae & PF & OECA \\
\hline Oenothera deltoides Torr. \& Frem. & large desert eveningprimrose & Onagraceae & AWF & OEDE \\
\hline Qenothera primiveris Gray & yellow desert eveningprimrose & Onảgraceae & AWF & OEPR \\
\hline Opuntia basilaris Engelın. \& Bigelow & beavertail cactus & Cactaceae & PF & OPBA \\
\hline Opuntia echinocarpa Engelm. \& Bigelow & silver cholla & Cactaceae & PF & OPEC \\
\hline Opuntia erinacea Engelm. \& Bigelow ex Engelm. & Mojave pricklypear & Cactaceae & PF & OPER \\
\hline Oryzopsis hymenoides (Roemer \& J. A. Schultes) Ricker ex Piper & Indian ricegrass & Poaceae & PG & ORHY \\
\hline Oxytheca perfoliata Torr. \& Gray & perfoliate oxytheca & Polygonaceae & AWF & OXPE \\
\hline Pectis papposa Harvey \& Gray & chinchweed & Asteraceae & ASF & PEPA \\
\hline
\end{tabular}


APPENDIX F (continued)

\begin{tabular}{|c|c|c|c|c|}
\hline Scientific Name & Common Name & Family & Lifeform & Code \\
\hline Pectocarya heterocarpa (I. M. Jonhston) I. M. Johnston & Chuckwalla pectocarya & Boraginaceae & AWF & PEHE \\
\hline Pectocarya platycarpa (Munz \& Johnston) Munz \& Johnston & broadfruit pectocarya & Boraginaceae & AWF & PEPL \\
\hline Pectocarya setosa Gray & bristly pectocarya & Boraginaceae & AWF & PESE \\
\hline Penstemon floridus Brandeg. & Panainit beardtongue & Scrophulariaceae & PF & PEFL \\
\hline Petalonyx nitidus S. Wats. & shining sandpaper-plant & Loasaceae & PS & PENI \\
\hline Phacelia cremulata Torr. ex S. Wats. & heliotrope phacelia & Hydrophyllaceae & AWF & PHCR \\
\hline Phacelia fremontii Torr. & Fremont phacelia & Hydrophyllaceae & AWF & PHFR. \\
\hline Phacelia mustelina Coville & weasel phacelia & Hydrophyllaceae & AF & PHMU \\
\hline Phacelia rotundifolia Torr. ex S. Wats. & roundleaf phacelia & Hydrophyllaceae & AF & PHRO \\
\hline Phacelia saxicola Gray & rock phacelia & Hydrophyllaceae & $\mathrm{AF}$ & PHSA \\
\hline Phacelia vallis-morlae J. Voss. & Death Valley phacelia & Hydrophyllaceae & AWF & PHVA \\
\hline Phlox stansburyi (Torr.) Heller & Stansbury phlox . & Polemoniaceae & PF & PHST \\
\hline Plantago ovata Forsk. & island plantain & Plantaginaceae & AWF & PLIN \\
\hline Poa secunda J. Presl & Sandberg grass & Poaceae & $\mathrm{PG}$ & POSA \\
\hline Psathyrotes annua (Nutt.) Gray & mealy rosettes & Asteraceae & $\mathrm{AF}$ & PSAN \\
\hline Psorothamnus fremontii (Torr. ex Gray) Barneby & Fremont indigobush & Fabaceae & PS & PSFR \\
\hline Psorothamnus polydenius (Torr. ex S. Wats.) Rydb. & glandular indigobush & Fabaceae & PS & PSPO \\
\hline Purshia glandulosa Curran & Mohave antelope-brush & Rosaceae & PS & PUGL \\
\hline Rafinesquia neomexicana Gray & desert chicory & Asteraceae & AWF & RANE \\
\hline Salazaria mexicana Torr. & bladder-sage & Lamiaceae & PS & SAME \\
\hline Salsola kali (L.) & Russian thistle & Chenopodiaceae & AF & SAIB \\
\hline Salsola paulsenii Lity. & barbwire Russian thistle & Chenopodiaceae & AF & SAPA \\
\hline Salvia columbariae Benth. & chia & Lamiaceae & $\mathrm{AF}$ & SACO \\
\hline Salvia dorrii (Kellogg) Abrams & desert-sage & Lamiaceae & PS & SADO \\
\hline Schismus arabicus Nees _- & Arabian Mediterranean-grass & Poaceae & $A W G^{*}$ & SCAR \\
\hline Sclerocactus polyancistrus (Engeln. \& Bigelow) Britt. \& Rose & Mojave fishhook cactus & Cactaceae & $\mathrm{PF}$ & $\mathrm{SCPO}$ \\
\hline Senecio flaccidus Less. & shrubby butterweed & Asteraceae & PS & SEDO \\
\hline Senecio multilobatus Torr. \& Gray ex Gray & basin butterweed & Asteraceae & PF & SEMU \\
\hline Sisymbrium altissimum L. & tumble mustard & Brassicaceae & $\mathrm{AF}$ & SIAL \\
\hline
\end{tabular}


APPENDIX F (continued)

\begin{tabular}{|c|c|c|c|c|}
\hline Scientific Name & Common Name & Family & Lifeform & Code \\
\hline Sphaeralcea aimbigua Gray & desert mallow & Malvaceae & PF & SPAM \\
\hline Sporobolus cryplandrus (Torr.) Gray & sand dropseed & Poaceae & PG & SPCR \\
\hline Stephanomeria exigua Nutt. & small wirelettuce & Asteraceae & AWF & STEX \\
\hline Stephanomeria parrvi Gray & Parry wirelettuce & Asteraceae & PF & STP1 \\
\hline Stephanomeria pauciflora (Torr.) A. Nels. & fewflower wirelettuce & Asteraceae. & $\mathrm{PF}$ & STP2 or STPA \\
\hline Stipa speciosa Trin. \& Rupr. & desert needlegrass & Poaceae & $\mathrm{PG}$ & STSP \\
\hline Streptanthella longirostris (S. Wats.) Rydb. & longbeak twistflower & Brassicaceae & AWF & STLO \\
\hline Stylocline micropoides Gray & woolly nest-straw & Asteraceae & AWF & STMI \\
\hline Syntrichopappus fremontii Gray & yellow syntrichopappus & Asteraceae & AWF & SYFR \\
\hline Tetradymia axillaris A. Nels. & Cottonthorn & Asteraceae & PS & TEAX \\
\hline Tetradymia glabrala Torr. \& Gray & littleleaf horsebrush & Asteraceae & PS & TEGL \\
\hline Thysanocarpus curvipes Hook. & hairy fringepod & Brassicaceae & AF & THCU \\
\hline Tiquilia nuttallii (Hook.) A. Richards & Nuttall tiquilia & Boraginaceae & $\mathrm{AF}$ & CONU \\
\hline Tricardia watsonii Torr. ex S. Wats. & three-hearts & Hydrophyllaceae & PF & TRWA \\
\hline Vulpia octoflora (Walt.) Rydb. & sixweeks fescue & Poaceae & AWG & VUOC \\
\hline Xylorhiza tortifolia (Torr. \& Gray) Greene & Mohave desertaster & Asteraceae & PF & MATO \\
\hline Yucca brevifolia Engelin. & Joshua tree & Agavaceae . & PT & YUBR \\
\hline
\end{tabular}

